\title{
INFLUÊNCIA DE CORREDOR FLORESTAL ENTRE FRAGMENTOS DA MATA ATLÂNTICA UTILIZANDO-SE A AVIFAUNA COMO INDICADOR ECOLÓGICO
}

\author{
FÁBIO ROSSANO DÁRIO
}

Engenheiro Florestal

Orientador: Prof. Dr. ÁLVARO FERNANDO DE ALMEIDA

Dissertação apresentada à Escola Superior de Agricultura "Luiz de Queiroz", Universidade de São Paulo, para obtenção do título de Mestre em Ciências, Área de Concentração: Ciências Florestais

PIRACICABA

Estado de São Paulo - Brasil

setembro - 1999 


\title{
INFLUÊNCIA DE CORREDOR FLORESTAL ENTRE FRAGMENTOS DA MATA ATLÂNTICA UTILIZANDO-SE A AVIFAUNA COMO INDICADOR ECOLÓGICO
}

\author{
FÁBIO ROSSANO DÁRIO
}

Aprovado em: 22.10.1999

Comissão julgadora:

Prof. Dr. Álvaro Fernando de Almeida

ESALQ/USP

Prof. Dr. Fabio Poggiani

ESALQ/USP

Prof. Dr. Jacques Marie Edme Vielliard

UNICAMP

Prof. ÁLVARO FERNANDO DE ALMEIDA

Orientador 


\section{Dados internacionais de Catalogação na Publicação (CIP) DIVISÃO DE BIBLIOTECA E DOCUMENTAÇÃO - Campus "Luiz de Queiroz"/USP}

\section{Dário, Fábio Rossano}

Influência de corredor florestal entre fragmentos da Mata Atlântica utilizando-se a avifauna como indicador ecológico / Fábio Rossano Dário. - - Piracicaba, 1999.

156 p. : il.

Dissertação (mestrado) - - Escola Superior de Agricultura Luiz de Queiroz, 1999.

Bibliografia.

1. Ave 2. Avifauna 3. Corredor florestal 4. Ecologia florestal 5. Eucalipto 6.

Fragmento florestal 7. Mata atlântica 8. Silvicultura 9. Sub-bosque 10. Vegetação

Nativa I. Título

CDD 598.2

Permitida a cópia total ou parcial deste documento, desde que citada a fonte - O Autor" 
É DEVER DE TODO SOCIALISTA A PROTEÇÃO DE TODOS OS OPRIMIDOS, DESDE OS ANIMAIS ATÉ OS SERES HUMANOS EXPLORADOS OU SUBMISSOS

ANTONIO GRAMSCI

(Ales, 1891 - Roma, 1937) 
À minha família, por tudo que fizeram

pela minha formação

À Cris, pelo carinho

OFEREÇO

Aos 40 anos da Revolução Cubana

\section{DEDICO}




\section{AGRADECIMENTOS}

Ao professor Álvaro Fernando de Almeida, pela orientação e pelos tantos anos de amizade, pesquisas, trabalhos e viagens pelos sertões do Brasil.

Aos professores Jacques Villieard pela orientação ao estudo da avifauna, Fábio Poggiani e Sérgius Gandolfi pelos esclarecimentos da ecologia, Ricardo Ribeiro Rodrigues e Jorge Tamashiro pelos ensinamentos de taxonomia vegetal, Antonio Natal Gonçalves pelo carinho com que acolheu seus alunos e Mário Tomazello Filho pelo incentivo e amizade.

Ao avô e professor Alceu de Arruda Veiga pelas sugestões, revisão e orientação.

Ao amigo Paulo Groke pelo total e indispensável apoio neste trabalho, e pela amizade sempre presente desde os tempos do bicho Katado.

Aos amigos Alexandre de Almeida (carazinho), André Ravetta (tapira), Cassio Henrique Giusti Cezare (nero), Eduardo Carvalho de Arruda Veiga (du), Fábio Rohe (trupico), Ionara Amélia Fernandes (itamarandiba), José Rubens Trevisan (rubão), Marcelo Castro Pereira (casmurro), Márcio Port Carvalho (alemão), Marta Regina Muniz (manga), Murilo Gambato de Mello (xenóbio), Patrícia Oliveira Rodrigues (pirralha), futuros engenheiros florestais, biólogos e ecólogos, que participaram dos levantamentos de campo, dando importantes contribuições para que o trabalho pudesse ser realizado.

À Companhia Suzano de Papel e Celulose, por todo o apoio e infra-estrutura disponibilizada e indispensável na realização dos trabalhos, em particular ao biólogo Maurício Machado, pela indicação da área e apoio de base, Marcelo Conde pelo apoio cartográfico e confecção dos mapas e à equipe operacional da 
G9 - Fazenda Cachoeira, da Divisão de Recursos Naturais, pelo apoio nos trabalhos de campo.

À ESALQ - USP pela oportunidade de desenvolver meu trabalho, ao Departamento de Ciências Florestais pela forma acolhedora em que recebeu seus alunos e à CAPES pelo apoio financeiro.

Ao clima de amizade proporcionado pelos amigos da turma de mestrado de 1996, em especial os "mato-grossenses" André Gustavo Nave (judith), Robson Fábio Lopes (tokito) e Daniela Fessel Bertani (dani).

À Marialice Poggiani e Eliana Sabino pelas orientações bibliográficas e ao amigo Paulo Eduardo dos Santos pelas revisões de última hora.

Aos meus irmãos Gêra, Dunga e Débora pelo carinho e orientações.

Ao amigo flamenguista Renato Moraes de Jesus por defender a Mata Atlântica e acreditar no meu trabalho.

À minha esposa Maria Cristina De Vincenzo, pela paciência e auxílio nos trabalhos de campo e escritório.

Aos meus pais pelo exemplo de vida. 


\section{SUMÁRIO}

LISTA DE FIGURAS

página

LISTA DE TABELAS

viii

RESUMO

ix

SUMMARY

$\mathrm{X}$

xii

1 INTRODUÇÃO

2 REVISÃO DE LITERATURA 3

2.1 A vegetação da Mata Atlântica $\quad 3$

2.2 O desmatamento na Mata Atlântica $\quad 7$

2.3 Os problemas da fragmentação de ambientes naturais 16

2.4 Correlações entre a vegetação e a fauna 23

2.5 Corredores de vegetação natural $\quad 31$

3 METODOLOGIA $\quad 35$

3.1 Localização e descrição da área 35

$\begin{array}{ll}3.2 \text { Clima } & 39\end{array}$

3.3 Geomorfologia, geologia e solo 40

3.4 Vegetação $\quad 41$

3.4.1 Formação florestal $\quad 41$

3.4.2 Cobertura vegetal $\quad 42$

3.4.3 Estrutura da paisagem 46

3.5 Amostragem da avifauna $\quad 53$

3.5.1 Métodos de amostragem $\quad 53$

3.5.2 Levantamento qualitativo $\quad 55$

3.5.3 Levantamento quantitativo $\quad 55$

3.5.4 Execução do levantamento quantitativo 56

3.5.4.1 Método de observações por pontos fixos 56

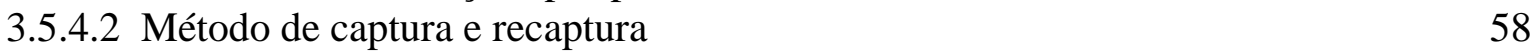

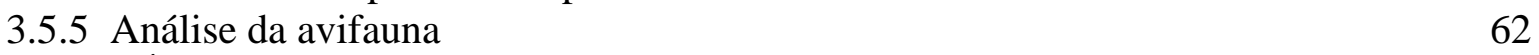

3.5.5.1 Índice pontual de abundância $\quad 62$

3.5.5.2 Freqüência de ocorrência $\quad 63$

3.5.5.3 Índice de Kendeigh $\quad 63$

3.5.5.4 Índice de diversidade de Shannon-Weaver $\quad 64$

$\begin{array}{ll}\text { 3.5.5.5 Índice de eqüidade } & 64\end{array}$

3.5.5.6 Índice de similaridade de Jaccard $\quad 65$

3.5.5.7 Freqüência de captura $\quad 65$

3.5.5.8 Freqüência de recaptura $\quad 66$

3.5.6 Guildas alimentares $\quad 66$

$\begin{array}{ll}\text { 3.5.7 Distribuição da avifauna na estrutura vertical } & 67\end{array}$ 
4 RESULTADOS E DISCUSSÃO 68

$\begin{array}{ll}4.1 \text { Avifauna } & 68\end{array}$

4.1.1 Composição geral da avifauna $\quad 68$

$\begin{array}{ll}\text { 4.1.2 Estrutura e comunidade trófica das aves } & 75\end{array}$

4.1.3 Método de observações por pontos fixos $\quad 82$

4.1.3.1 Quantidade de indivíduos registrados $\quad 82$

4.1.3.2 Curvas do número acumulado de espécies $\quad 87$

4.1.3.3 Índice pontual de abundância $\quad 89$

4.1.3.4 Freqüência de ocorrência 97

4.1.3.5 Índice de Kendeigh 101

4.1.36 Índice de diversidade de Shannon-Weaver 105

$\begin{array}{ll}\text { 4.1.3.7 Índice de eqüidade } & 107\end{array}$

4.1.3.8 Índice de similaridade de Jaccard $\quad 108$

4.1.4 Método de captura e recaptura 109

4.1.4.1 Quantidade de indivíduos registrados 109

4.1.4.2 Esforço de captura $\quad 112$

4.1.4.3 Curvas do número acumulado de espécies 112

4.1.4.4 Freqüência de captura 113

4.1.4.5 Freqüência de recaptura 116

4.2 Eficiência amostral dos métodos utilizados 117

$\begin{array}{ll}4.3 \text { Efetividade do corredor } & 121\end{array}$

5 CONCLUSÕES 123

$\begin{array}{ll}\text { ANEXOS } & 125\end{array}$

REFERÊNCIAS BIBLIOGRÁFICAS 133 


\section{LISTA DE FIGURAS}

página

Figura 01. Localização da região de estudo 37

Figura 02. Localização dos ambientes estudados 38

Figura 03. Esquema do perfil da vegetação 48

Figura 04. Vista parcial do fragmento vermelho e dos plantios de eucalipto no 49 entorno

Figura 05. Detalhe do interior do fragmento vermelho 49

Figura 06. Vista parcial do fragmento amarelo 50

Figura 07. Detalhe do interior do fragmento amarelo 50

Figura 08. Vista parcial do corredor $\quad 51$

Figura 09. Detalhe do interior do corredor com o córrego 51

Figura 10. Detalhe do sub-bosque de eucalipto $\quad 52$

Figura 11. Detalhe da rede neblina instalada no interior do fragmento amarelo 61

Figura 12. Micrastur ruficollis (gavião caburé), representante da guilda inseto- $\quad 61$ carnívora, capturado na rede neblina

Figura 13. Synallaxis ruficapilla (joão teneném), representante da guilda 81 insetívora

Figura 14. Chiroxiphia caudata (tangará dançarino), representante da guilda 81 onívora

Figura 15. Curvas do número acumulado de espécies para as áreas estudadas $\quad 88$

Figura 16. Número de espécies de cada guilda alimentar presente nas áreas 95 estudadas

Figura 17. Porcentagem dos indivíduos de cada guilda alimentar observados nas 96 áreas estudadas

Figura 18. Curva do número acumulado de espécies para as áreas estudadas 


\section{LISTA DE TABELAS}

página

Tabela 01. Valores mensais médios, máximos, mínimos e valores absolutos da precipitação atmosférica do Município de Paraibuna - SP

Tabela 02. Valores mensais médios, máximos e mínimos de temperatura do Município de Paraibuna - SP

Tabela 03. Lista das espécies vegetais identificadas nas áreas de estudo

Tabela 04. Total de horas de observações para cada área estudada

Tabela 05. Total de dias e horas de levantamento por captura e recaptura

Tabela 06. Relação das ordens, subordens, famílias e subfamílias registradas na área de estudo

Tabela 07. Relação das famílias, subfamílias e espécies registradas na área de estudo

Tabela 08. Composição da avifauna por guilda e pela ocupação vertical da floresta

Tabela 09. Espécies registradas nas áreas de estudo através do método de observações por pontos fixos e número de contatos

Tabela 10. Número de espécies, famílias e ordens observadas em cada área

Tabela 11. Índice de densidade geral para as áreas estudadas

Tabela 12. Índice pontual de abundância para as espécies registradas em cada área estudada

Tabela 13. Número de espécies e porcentagem dos indivíduos de diferentes guildas alimentares observados em cada área de estudo

Tabela 14. Freqüência de ocorrência para as espécies registradas em cada área estudada

Tabela 15. Índice de Kendeigh para as espécies registradas em cada área estudada

Tabela 16. Número de populações da avifauna para os 4 ambientes estudados, de acordo com as distribuições dos índices de Kendeigh

Tabela 17. Índice de diversidade de Shannon-Wiever calculado para as áreas estudadas

Tabela 18. Índice de eqüidade calculado para as áreas estudadas

Tabela 19. Índice de similaridade de Jaccard calculado para as áreas estudadas

Tabela 20. Relação das espécies capturadas e recapturadas

Tabela 21. Número de espécies, famílias e ordens registradas em cada área

Tabela 22. Esforço de captura para as áreas estudadas

Tabela 23. Frequiência de captura calculada para as áreas de estudo

Tabela 24. Frequiência de recaptura calculada para as áreas de estudo

Tabela 25. Eficiência amostral dos métodos utilizados no levantamento da avifauna

Tabela 26. Lista das espécies recapturadas em áreas diferentes da captura 


\title{
INFLUÊNCIA DE CORREDOR FLORESTAL ENTRE FRAGMENTOS DA MATA ATLÂNTICA UTILIZANDO-SE A AVIFAUNA COMO INDICADOR ECOLÓGICO
}

\author{
Autor: Fábio Rossano Dário \\ Orientador: Prof. Dr. Álvaro Fernando de Almeida
}

\section{RESUMO}

O estudo foi realizado em área localizada na Serra do Mar, no domínio da Mata Atlântica, na formação florestal denominada Floresta Ombrófila Densa Atlântica, no Município de Paraibuna, Estado de São Paulo, Brasil, entre as coordenadas geográficas $23^{\circ} 31^{\prime} 21^{\prime \prime}$ e $23^{\circ} 32^{\prime} 36^{\prime \prime}$ de Latitude Sul e $45^{\circ} 39^{\prime} 33^{\prime \prime}$ e $45^{\circ} 41^{\prime} 54^{\prime \prime}$ de Longitude Oeste e $1.136 \mathrm{~m}$ de altitude.

Foram estudados 3 fragmentos de vegetação natural de 46,92 ha, 4,28 ha e 26,38 ha e uma área de plantio de eucalipto adjacente, com sub-bosque bem desenvolvido, sendo a vegetação dos fragmentos, mata ciliar em estágio médio de regeneração secundária. $\mathrm{O}$ fragmento de menor área constitui-se num corredor de vegetação natural, interligando os 2 fragmentos maiores.

O principal objetivo foi analisar os grupos de aves afetados pela fragmentação florestal e avaliar os impactos causados pela fragmentação e o isolamento destas áreas e, utilizando a avifauna como indicador ecológico, analisar a efetividade do corredor na passagem de material genético entre os fragmentos.

Os métodos utilizados para o registro da avifauna foram o de observações por pontos fixos e captura e recaptura com auxilio de redes instaladas no sub-bosque dos fragmentos e do plantio de eucalipto, além das observações qualitativas realizadas entre os levantamentos.

Considerando-se os métodos utilizados e as 4 áreas estudadas, foi possível registrar, em 80 horas de observações e 2.502 horas rede, 135 espécies de aves, distribuídas em 33 famílias e 14 ordens, sendo as principais guildas a insetívora, onívora e granívora, todas ocupando o sub-bosque. 
Através dos dados dos levantamentos foram analisados parâmetros como número de espécies, abundância, freqüência de ocorrência, diversidade, eqüidade, similaridade, composição das espécies e guildas alimentares.

A composição de espécies foi afetada pela fragmentação e redução da área de vegetação natural. A quantidade e diversidade de aves apresentou relação direta com o tamanho do fragmento e estrutura da vegetação, e inversa com o grau de isolamento.

Não houve a constatação da passagem pelo corredor, de nenhum indivíduo da avifauna tipicamente florestal. O registro de grande quantidade de espécies comuns aos 2 fragmentos e corredor, de diversos grupos tróficos e distribuídas nos diferentes estratos da vegetação, demonstra a existência de uma dinâmica entre estes ambientes.

O corredor está funcionando como uma efetiva área de hábitat, complementando a cadeia de reserva existente. A sua largura está diretamente ligada a efetividade, no entanto, a largura ideal é uma medida empírica, pois existem diversas variáveis que podem estar interferindo no fluxo das espécies pelo corredor, como área, grau de isolamento, estrutura e composição da vegetação, efeito de borda, tipo de vizinhança e pressões antrópicas.

Os plantios de eucalipto, mesmo com o sub-bosque bem desenvolvido, formam uma barreira para diferentes espécies da avifauna, principalmente as florestais. 


\title{
INFLUENCE OF FOREST CORRIDOR AMONG FRAGMENTS OF THE
} ATLANTIC FOREST USING AVIFAUNA AS ECOLOGICAL INDICATOR

\author{
Author: Fábio Rossano Dário \\ Adviser: Prof. Dr. Álvaro Fernando de Almeida
}

\section{SUMMARY}

The study was carried out in an area located at "Serra do Mar", belonging to "Mata Atlântica" formation, also known as Atlantic Rain Forest, near the town of Paraibuna, State of São Paulo, Brazil (located at latitude $23^{\circ} 31^{\prime} \mathrm{S}$ to $23^{\circ} 33^{\prime}$ S, longitude $45^{\circ} 39^{\prime} \mathrm{W}$ to $45^{\circ} 42^{\prime} \mathrm{W}$ and altitude of 944 to $1.136 \mathrm{~m}$ ).

Three fragments of natural vegetation (sizes of 46.92 ha, 4.28 ha and $26.38 \mathrm{ha}$ ) and an adjacent area of eucalypts plantation were utilized for the surveys. In all situations the understorey was quite prominent and the vegetation of the gallery forest fragments were in a medium stage of secondary regeneration. The fragment of smaller size was formed by a corridor of natural vegetation, connecting the two larger fragments.

The main objective of the study was to analyze the groups of birds that were affected by the forest fragmentation and, additionally, to evaluate the impacts caused by the fragmentation and the isolation degree of these areas, using birds as ecological indicator to analyze the corridor's effectiveness to the passage of genetic material among fragments.

The methods used to register the avifauna specimens were the technique of observations per fixed points, the captures and recaptures supported by mist nets installed within the fragments understorey and within an eucalypts plantation and the qualitative studies accomplished among the surveys.

Taking into account 80 hours of observations and 2.502 hours of mist net in all studied areas, it was possible to register a total of 135 species of birds, distributed 
over a range of 33 families and 14 orders. The main species were characterized as insecteating, omnivorous and grain-eating, all of them occupying the understorey level.

Through the data of the surveys parameters, analyzed as avian species number, abundance, occurrence frequency, diversity, equity, similarity, species composition and feeding behaviour.

The species composition was affected by the fragmentation and also by the reduction of the natural vegetation. The quantity and diversity of birds showed a direct relationship with the size of the fragment and structure of the vegetation and an inverse relationship with the isolation degree of the area.

There was no evidence of passage of any typical forest avifauna individuals by the corridor. The registration of great quantity of common species to both fragments and corridor, of several trophic groups and distribution in the different strata of the vegetation, demonstrates the dynamics among these environments.

The corridor is working as an effective habitat area, complementing the network of existent reserve. The width is directly attached to the corridor effectiveness, however, the ideal width is an empiric measure, because several variables can affect the species flux to the corridor, as area, isolation degree, structure and vegetation composition, edge effect, neighborhood type and anthropic pressures.

The eucalypts plantations, even containing the understorey level quite prominent, form an effective barrier to different avifauna species, mainly over those ones that live in the core zone of the forest. 


\section{INTRODUÇÃO}

A Mata Atlântica é uma das formações florestais mais importantes do planeta, principalmente pela quantidade de espécies endêmicas existentes, o que indica que este ecossistema é um centro de evolução.

Infelizmente, este importante ecossistema foi vítima do extrativismo predatório, que destruiu, nos últimos 500 anos, mais de $90 \%$ da sua cobertura original. A Mata Atlântica é considerada internacionalmente como uma das florestas tropicais mais ameaçadas de extinção do planeta.

O processo de destruição da Mata Attântica iniciou-se com as explorações do Pau-brasil e atividades econômicas no período colonial, e vem ocorrendo até hoje. Com o desmatamento e a fragmentação de ambientes naturais, são destruídos sistemas biológicos complexos e diversificados, causando a extinção de populações, espécies e comunidades ecológicas inteiras.

A maior parte dos fragmentos florestais existentes hoje na Mata Atlântica sofreu algum tipo de perturbação antrópica. A fragmentação de ambientes naturais é resultado de um processo histórico de perturbação da vegetação. A estrutura e dinâmica destes fragmentos podem estar sendo afetadas por diversos fatores, como a área, forma, tipo de vizinhança e grau de isolamento.

Fragmentos que se encontram isolados há muito tempo, degeneram pela perda de animais polinizadores, dispersores e predadores, ocasionando um desequilíbrio na biodiversidade, afetando principalmente as espécies endêmicas e de baixa densidade populacional.

Mudanças na estrutura e composição da vegetação interferem diretamente na organização populacional da fauna, pois alteram a quantidade de nichos que abrigam 
uma diversidade de habitantes nos diferentes níveis da estratificação, e o ambiente natural remanescente pode tornar-se pequeno demais para abrigar espécies que necessitam de grandes áreas para sobreviver.

Devido às interações entre a vegetação e a avifauna, as aves constituem-se num excelente indicador ecológico para se registrar as alterações em ambientes florestais. Ocupando diversos nichos tróficos, a diversidade de espécies varia de acordo com a capacidade do ambiente na oferta de alimentos.

Os padrões de movimentação das aves são determinados principalmente pela estrutura e composição da vegetação, distâncias das árvores e disposição espacial dos elementos florestais. Fragmentos florestais isolados podem ser um problema sério para as espécies que necessitam de grandes áreas para sobreviver e que não se translocam com facilidade em ambientes com vegetação diferente do que vive.

A ligação destes fragmentos isolados por corredores de vegetação natural, pode ser uma estratégia para mitigar os efeitos da ação antrópica, possibilitando a sustentação de determinadas populações de animais e vegetais existentes nestes ambientes. No entanto, é muito importante conhecer a estrutura e dinâmica destes fragmentos, pois se estes núcleos de dispersão forem interligados pelos corredores de vegetação natural, os corredores poderão sofrer influência direta dos fragmentos.

O objetivo deste trabalho é analisar a situação de dois fragmentos de vegetação natural secundária na Mata Atlântica, isolados por plantios de Eucalyptus spp em diferentes idades e ligados por um corredor de vegetação natural, estudar a avifauna existente nos fragmentos, sua distribuição nos diferentes estratos da vegetação, identificando as principais guildas existentes, verificar a eficiência do corredor como passagem de material genético animal e vegetal, utilizando-se a avifauna como indicador ecológico e identificando os grupos de aves que se beneficiam da sua estrutura. 


\section{REVISÃO DE LITERATURA}

\subsection{A vegetação da Mata Atlântica}

Nos documentos elaborados pelo naturalista francês André Thévet, em 1578 (Singularitez de la France Antarctique) e pelo missionário francês Jean de Léry, em 1580 (Histoire d'un voyage faiet en la terre du Brésil), há descrições que proporcionam uma idéia perfeita de como as matas e os campos do Brasil se apresentavam no início do período colonial e quais eram os seus principais componentes (Hoehne, 1937).

Os primeiros trabalhos verdadeiramente científicos sobre a vegetação brasileira foram realizados pelo naturalista alemão Georg Marcgrave e pelo naturalista holandês Wilhem Piso, publicados em 1648, em documento intitulado Historia naturalis brasiliae (Sick, 1997).

Para a reconstrução da fisionomia do Estado de São Paulo, existem documentos de inestimável valor botânico e histórico, elaborados pelos naturalistas que percorreram o Brasil principalmente no século XIX, como Wied-Neuwied (1821), Martius (1824), Spix (1825), Gardner (1846), Saint-Hilaire (1851), Avé-Lallemant (1859), Agassiz (1866), Denis (1888), Löfgren (1890 e 1896) e Warming (1892).

O botânico alemão Martius (1840) apresentou o primeiro mapa fitogeográfico do Brasil, contendo a Tabulae physiognomicae, onde estabeleceu para a geografia botânica brasileira as seguintes divisões dos grupos florísticos: Napaeae, Dryades, Oreades, Hamadryades e Naiades. O Estado de São Paulo está incluído em dois grupos, Oreades e Dryades, sendo que neste último encontram-se as regiões das serras e das montanhas cobertas com florestas virgens, compreendendo a faixa litoral de São Paulo. 
Engler (1889) e Sampaio (1938), remanejaram o sistema de Martius (1840), permitindo a Hoehne (1940) inserir toda a região da Serra do Mar dentro das Formações Higrófilas, que são constituídas de florestas muito viçosas, onde há grande concentração de plantas epífitas, principalmente das famílias Orchidaceae, Bromeliaceae, Gesneriaceae, Araceae, Melastomataceae e Rubiaceae, entre muitos musgos. Esta vegetação dendrícola é um índice seguro da atmosfera saturada de umidade.

O termo Floresta Atlântica foi utilizado por Burmeister em 1853, que dividiu a vegetação brasileira em 3 grandes zonas: Amazônia, Brasil Central e Floresta Atlântica (Burmeister, 1980). Este termo também foi utilizado por Pelzeln, do Museu de Viena, que classificou muitas espécies da avifauna existente nesta região, através das coleções do zoólogo Natterer, que chegou ao Brasil junto com Spix e Martius, e aqui ficou 18 anos realizando suas pesquisas, entre 1817 e 1835 (Pelzeln, 1871).

Alguns autores defendem os termos Floresta Atlântica ou Mata Atlântica como sendo referentes às áreas de domínio da Floresta Pluvial Tropical ou Floresta Latifoliada Tropical Úmida de Encosta (Azevedo, 1959).

O termo Floresta Pluvial Tropical foi citado pela primeira vez por Schimper (1903) e utilizado por Richards (1952). Coutinho (1962) adotou o nome Mata Pluvial Tropical, proposto por Wettstein (1904).

Segundo Rizzini (1963), a Floresta Atlântica é constituída pela Floresta Pluvial Baixo Montana e Montana, com o primeiro tipo ocorrendo nas porções mais baixas das serras e o segundo nas partes de mediana altitude. Para Magnanini (1965), esta vegetação encontra-se inserida na Formação da Encosta Atlântica.

Ellemberg \& Mueller-Dombois (1966), apresentaram o termo Floresta Ombrófila Densa, com as subdivisões Montana e Submontana, substituindo Pluvial (de origem latina) por Ombrófila (de origem grega), ambos com o mesmo significado, "amigo das chuvas", empregando pela primeira vez os termos Densa e Aberta como divisão das florestas dentro do espaço intertropical, pois apresenta as duas fisionomias ecológicas, tanto na Amazônia como nas áreas costeiras. 
Andrade-Lima (1966) utilizou o termo Floresta Perenifólia Latifoliada Higrófila Costeira. Ab'Saber (1966) inseriu a Mata Atlântica no Domínio Morfoclimático Tropical Úmido do Brasil de Sudeste, simbolicamente reconhecido como Domínio dos Mares de Morros, que Romariz (1968) denominou Floresta Latifoliada Tropical Úmida de Encosta.

Eiten (1970) criou o termo Floresta Costeira Atlântica, subdividida em Floresta Alta do Litoral, Floresta da Encosta da Serra do Mar, Floresta da Crista da Serra do Mar, Floresta Sempre Verde do Planalto, Floresta Semidecídua do Planalto e Floresta Mista Latifoliada de Araucária, todas dentro da subsérie florestal.

Hueck \& Seibert (1972) adotaram a terminologia Floresta Pluvial Atlântica, denominando o primeiro tipo descrito por Rizzini (1963), de Floresta Litorânea ou Costeira e o segundo, de Floresta de Montanhas, apresentados junto ao Mapa de Vegetação da América do Sul.

O termo Mata Atlântica tem sido muito utilizado nos últimos anos, em trabalhos que descrevem sua estrutura e composição (Ab'Saber, 1950 e 1977; Jesus, 1986; Klein, 1990; Mantovani et al., 1990; Joly et al., 1991; Fontes et al., 1992; Leitão Filho, 1993; Giannoti et al., 1994; Dário \& Monteiro, 1994; Kim, 1996).

A Mata Atlântica estendia-se, originalmente, desde o paralelo $5^{0} 30^{\prime} \mathrm{Sul}$ até $30^{\circ}$ 00' Sul, entre os Estados do Rio Grande do Norte e Rio Grande do Sul, numa faixa cuja largura máxima seria de $200 \mathrm{~km}$ e atingindo altitudes superiores a $2.000 \mathrm{~m}$ (Magnanini, 1965). Na região do Rio Doce, ultrapassava a Serra do Mar, encontrando seu limite na borda da Serra do Espinhaço. Nos Estados de São Paulo, Paraná e Santa Catarina, a Mata Atlântica estendia-se por toda a extensão, até o Rio Paraná (Campos, 1912).

O Decreto $\mathrm{n}^{\mathrm{o}} 750$ de 10 de fevereiro de 1993, no artigo $3^{\circ}$, considera Mata Atlântica as formações florestais e ecossistemas associados inseridos no domínio Mata Atlântica, com as respectivas delimitações estabelecidas pelo Mapa de Vegetação do Brasil (Instituto Brasileiro de Geografia e Estatística, 1988): Floresta Ombrófila Densa Atlântica, Floresta Ombrófila Mista, Floresta Ombrófila Aberta, Floresta Estacional 
Semidecidual, Floresta Estacional Decidual, manguezais, restingas, campos de altitude, brejos interioranos e encraves florestais do Nordeste.

A Mata Atlântica está situada, no Estado de São Paulo, nas encostas da Serra do Mar, com penetrações mais para o interior, particularmente no sul do Estado. É a formação florestal mais antiga do Brasil, estabelecida há cerca de 70 milhões de anos (Leitão Filho, 1982).

Localizada sobre um embasamento cristalino pré-cambriano, que já estava plenamente estabelecido no início do Terciário, a Mata Atlântica tem seu posicionamento ligado ao relevo, umidade e precipitação atmosférica, o que propicia uma formação de árvores altas, com sub-bosque sombrio e úmido, onde vegetam inúmeras ervas e epífitas (Joly et al., 1991).

Silva (1980) estudou a composição florística de um trecho da Mata Atlântica de encosta do Município de Ubatuba, Estado de São Paulo, onde registrou 123 espécies arbóreas distribuídas em 87 gêneros e 41 famílias. As 10 famílias consideradas mais importantes foram: Euphorbiaceae, Rubiaceae, Arecaceae, Leguminosae, Lauraceae, Bombacaceae, Elaeocarpaceae, Myrtaceae, Apocynaceae e Nyctaginaceae, e as 10 espécies de maior valor de importância para a região foram: Mabea brasiliensis, Hieronyma alchorneoides, Syagrus pseudococos, Eriotheca penthaphylla, Sloanea guianensis, Bathysa gymnocarpa, Sclerolobium denudatum, Guapira calycantha, Malouetia arborea e Qualea gestasiana.

Mantovani et al. (1990), estudaram as formações vegetais que ocorrem sobre a Serra do Mar ao longo da costa atlântica no Estado de São Paulo, e citam as famílias Rubiaceae, Myrtaceae, Euphorbiaceae, Arecaceae, Melastomataceae, Combretaceae, Nyctaginaceae, Monimiaceae, Lauraceae e Lecythidaceae como as mais importantes em mata de fundo de vale no Município de Salesópolis.

As lianas ocupam posição de destaque, tanto na riqueza como na diversidade na Mata Atlântica. Em trabalhos realizados por vários pesquisadores no litoral norte de São Paulo, foram encontradas 363 diferentes espécies pertencentes a 43 famílias, sendo as mais ricas em espécies, Asteraceae (51 spp), Fabaceae (44 spp), Bignoniaceae (32 spp), Sapindaceae (26 spp), Asclepiadaceae (24 spp), Convolvulaceae 
(23 spp), Apocynaceae (17 spp), Passifloraceae (16 spp) e Malpighiaceae (14 spp) (Kim \& Leitão Filho, 1995).

A composição florística da Mata Atlântica varia continuamente de norte a sul, com o índice pluviométrico, drenagem e situação topográfica. A face de inclinação das montanhas voltada para o oceano recebe mais chuva, que aumenta com a altitude. A precipitação varia em média 1.000 a $1.500 \mathrm{~mm} / \mathrm{ano}$ ao nível do mar, ocorrendo de $850 \mathrm{~mm} / \mathrm{ano}$ no Município de Cabo Frio, Estado do Rio de Janeiro até $4.500 \mathrm{~mm} /$ ano nos topos dos morros (Eiten, 1992).

A Mata Atlântica, reduzida hoje a poucos remanescentes, está na lista de prioridades de conservação da União Internacional para a Conservação da Natureza e Recursos Naturais. O maior perigo para a fauna concentra-se nesta faixa litorânea, onde encontram-se dois terços das espécies de aves registradas no Brasil (Sick, 1997).

É muito grande o montante de endemicidade na Mata Atlântica, indicando que este rico ecossistema é um centro de evolução, havendo entre tantas espécies da fauna, 160 espécies de aves endêmicas. A grande variedade de espécies animais e quantidade de endemicidade na Mata Atlântica está associada, entre outros fatores, à existência de cerca de 10 mil espécies de plantas (Fundação SOS Mata Atlântica, 1992).

\subsection{O desmatamento na Mata Atlântica}

O zoólogo alemão Johann Baptist von Spix e o botânico alemão Karl Friedrich Philip von Martius, em viagem do Rio de Janeiro à cidade de São Paulo, no ano de 1817, descrevem desta forma as suas primeiras impressões da Serra do Mar, no Estado de São Paulo:

"Continuávamos ainda na montanha, embora já se espacejassem os cumes arredondados, aparecendo risonhas roças de milho, mandioca e cana, de maior extensão, que davam agradável impressão ao viajante, em vez das matas virgens tenebrosas, cuja uniformidade silenciosa, o angustia e oprime contra vontade“ (Spix \& Martius, 1981). 
A maior parte das atividades econômicas do Brasil, desde o período colonial até o presente, tem se concentrado na faixa litorânea, o que resultou num processo de desmatamento em grande escala da Mata Atlântica (Dean, 1983).

Os Ciclos Econômicos pelos quais o Brasil passou foram extremamente prejudiciais ao país em termos ecológicos e florestais. Em 1501, amostras do primeiro dos tesouros do Brasil foram enviadas para Portugal. Tratava-se de uma madeira corante chamada Ibirapitanga pelos tupis, e que os portugueses passaram a chamar Pau-brasil. A grande e crescente demanda européia por corantes e tintas transformou o Pau-brasil num potencial para o comércio (Dean, 1996)

Iniciava-se o Ciclo do Pau-brasil (Caesalpinia echinata Lam.), período em que foram depredadas enormes extensões de matas do litoral brasileiro (Siqueira, 1982).

A primeira notícia de exploração florestal sistemática que se tem do Brasil data de 1511, quando a nau Bretoa transportou, a partir de Cabo Frio, 125 toneladas de Pau-brasil apenas em uma viagem. Esta carga de madeira teria resultado de pouco mais de 300 árvores. $\mathrm{O}$ manifesto de carga da Bretoa ainda registra 23 periquitos, 16 felinos, 19 macacos e 15 papagaios, todos capturados pelos tupis. Em 1532, a nau Pélérine transportou 3 mil peles de onça, 300 macacos e 600 papagaios (Dean, 1996).

Nos primeiros anos de comércio foram coletadas cerca de 1.200 toneladas de madeira de Pau-brasil a cada ano. Em 1588, passaram pela aduana portuguesa 4.700 toneladas de Pau-brasil, talvez metade do verdadeiro volume. Havia também o tráfico francês clandestino de madeiras corantes, que era tão bem estruturado quanto o dos portugueses, além do contrabando feito pelos navios espanhóis e ingleses. Em conjunto, todos estes negociantes podem ter provocado a extração de 12 mil toneladas de Paubrasil por ano, ao longo do século XVI. Calcula-se que essa tonelagem exigiu a derrubada de cerca de 2 milhões de árvores, afetando 600 mil hectares da Mata Atlântica (Dean, 1996).

Jean de Léry, cuja vinda para o Brasil se prende à fundação da França Antártica por Villegagnon, escreveu uma história de sua viagem, editada pela primeira 
vez em 1578, onde relata como as árvores de Pau-brasil eram abatidas pelos índios e transportadas até os navios franceses e portugueses:

"Os selvagens em troca de algumas roupas, camisas de linho, chapéus, facas, machados, cunhas de ferro e demais ferramentas trazidas por franceses e outros europeus, cortam, serram, racham, toram e desbastam o Pau-brasil, transportando-o nos ombros nus às vezes de duas a três léguas de distância, por montes e sítios escabrosos até a costa junto aos navios ancorados, onde os marinheiros o recebem" (Léry, 1980).

No sul foram portugueses e franceses que continuaram a devastação de nossas matas, iniciada pelos indígenas para a caça e a cultura, especialmente da mandioca, usando o fogo como principal ferramenta para limpar a área a ser cultivada. Tais fatos foram relatados por Hans Staden, náufrago feito prisioneiro pelos tupinambás, na região de São Vicente, Estado de São Paulo, que reuniu suas observações em um livro publicado pela primeira vez na Alemanha, em 1556. No Norte e Nordeste foram os franceses e holandeses que continuaram a obra de devastação de nossas florestas costeiras (Ferri, 1980).

Em 1600, o relacionamento humano com a Mata Atlântica tinha se transformado, principalmente porque a maioria dos seus habitantes humanos originais havia desaparecido e o número de invasores era insuficiente para substituí-los. Estes homens da Mata Atlântica, assim como todas as suas criaturas, haviam armazenado, durante 12 mil anos, seus próprios estoques de informações. Cada grupo havia atribuído nomes a centenas de espécies para as quais encontraram algum uso e sobre as quais conheceram os hábitats, estações, hábitos e as suas relações com outras espécies. Uma vez que os recursos e experiências de cada aldeia diferiam dos de seus vizinhos, milhares de espécies da Mata Atlântica tinham sido catalogadas na memória de seus habitantes humanos. Apenas a tradição oral preservava esta cultura. Uma vez retirados os indígenas de seus hábitats, toda essa informação começou a se deteriorar, e a floresta se tornou estranha e carente de propósito humano (Dean, 1996).

Gaspar Barléu, intelectual francês, publicou em 1647 um estudo do domínio holandês no nordeste brasileiro, dos feitos praticados pelo conde Maurício de Nassau-Siegen em Pernambuco, onde aborda aspectos da cultura local: 
“O sertão do Brasil, a dez ou doze léguas da costa, produz o Pau-brasil, não em matas inteiras e cerradas, mas esparsamente, de mistura com outras árvores. Ocupam-se os negros em cortá-lo nas suas folgas e nas horas vagas" (Barléu, 1974).

A atividade florestal, com a exploração de madeiras nativas, constituiu-se, até o início do século XVII, na principal fonte de divisa da Coroa Portuguesa. A exploração do Pau-brasil só terminou em 1875, num ciclo de 375 anos de devastação contínua desta madeira (Reis, 1982).

A agricultura colonialista no Sudeste iniciou-se em 1532 no litoral, com o cultivo da cana-de-açúcar e, em menor escala, das culturas de subsistência, baseadas principalmente no cultivo da mandioca e do milho (Guillaumon \& Marcondes, 1978).

No Ciclo do Açúcar, enormes extensões de florestas foram retiradas e simplesmente queimadas, para dar lugar às culturas da cana. Algumas árvores foram aproveitadas para edificar as casas de engenho e construções diversas para abrigar a população que entrava em processo de crescimento (Siqueira, 1982).

O açúcar tornou-se a única atividade econômica de grande vulto que vinculava a região da Mata Atlântica à metrópole, afora o corte do Pau-brasil. Calcula-se que até 1700, cerca de 150 anos após a exportação do açúcar alcançar escala comercial, os campos de cana teriam eliminado cerca de 100 mil hectares da Mata Atlântica. Outros 120 mil hectares teriam sido eliminados principalmente no abastecimento de energia para os engenhos (Dean, 1996).

As autoridades coloniais estavam desesperadas para localizar ouro, que salvaria a Coroa portuguesa dos efeitos desastrosos da perda das colônias asiáticas e de grande parte do mercado do açúcar para o Caribe. Em 1690 uma das bandeiras descobriu ouro, e a partir desta data, iniciou-se uma devastação ampla e permanente da Mata Atlântica (Dean, 1996).

No Ciclo da Mineração, com o deslocamento das entradas e bandeiras, em busca dos minérios, foram se instalando em suas passagens vilas e povoados, que necessitaram de novos desmatamentos. Durante este ciclo deu-se paralelamente o desenvolvimento da pecuária, que necessita de grandes áreas de pastagem, que vieram a ocupar o lugar das matas primitivas (Siqueira, 1982). 
As grandes descobertas de ouro e diamante no Brasil do século XVIII foram as mais importantes ocorridas no Novo Mundo colonial. O volume total de ouro obtido durante este século teria revirado 400 mil hectares da Mata Atlântica. As lavras geralmente se concentravam ao longo dos leitos dos riachos, causando grandes danos ecológicos, principalmente às associações de plantas higrófilas (Dean, 1996).

Até 1763, o pólo político e econômico está no Nordeste do país. A transferência do trono vice-real de Salvador para o Rio de Janeiro em 1763 sinalizou o desejo da Coroa de aumentar o controle sobre os embarques de ouro e diamante, na época em preocupante declínio (Pinto, 1979).

Com o declínio da produção do ouro e diamante na metade do século XVIII, os garimpeiros adotaram a lavoura e a pecuária, estendendo seus domínios cada vez mais para o interior da floresta ainda intocada. O século XVIII representou o início de uma tendência irreversível e cumulativa na exploração da Mata Atlântica (Dean, 1996).

O gado bovino foi introduzido inicialmente em São Vicente, talvez com a expedição de Martim Afonso de Souza em 1532. Em 1700 havia pelo menos 500 fazendas de gado no interior do Nordeste. O sistema de pecuária era extraordinariamente improdutivo, com pasto degradado permitindo apenas uma cabeça para cada 2 a 5 hectares. No entanto, a criação de gado atingiu grandes proporções durante o século XVIII (Saint-Hilaire, 1847).

A mineração, a lavoura e a engorda de gado no Sudeste podem ter eliminado, durante o século XVIII, outros 3 milhões de hectares da Mata Atlântica (Dean, 1996).

Tão ampla, completa e irreversível havia sido a eliminação da floresta durante o século XVIII, que o botânico alemão Martius, em 1810, foi levado a supor que na região de ouro e diamante, a sudoeste de Minas Gerais nunca havia existido floresta, mas vegetação de campos e gramados nativos (Hueck, 1957).

O Ciclo do Café inicia-se com plantios realizados no Rio de Janeiro. Em 1790, o café chega ao Estado de São Paulo, com inúmeras lavouras se esparramando 
pelos contrafortes da Serra do Mar e pelo Vale do Paraíba, passando depois para o interior do Estado de São Paulo, Minas Gerais, Espírito Santo e Paraná (Taunay, 1935).

Em 1850, Dom Pedro II editou a Lei no ${ }^{0}$ 601, que proibia a exploração florestal em terras descobertas. A fiscalização, no entanto, a cargo dos municípios, ficou relegada a segundo plano, pois o desmatamento era considerado necessário ao progresso, principalmente no estabelecimento de extensas lavouras de café (Reis, 1982). Neste mesmo ano, o Brasil produzia cerca de $50 \%$ da produção mundial, tornando-se assim o primeiro produtor do mundo. Com o café, o Estado de São Paulo alcançou um surto extraordinário de desenvolvimento em todos os setores (Graner \& Godoy Júnior, 1967).

Em 1900 havia 650 milhões de pés de café no Estado de São Paulo. Estima-se que, por volta desta época, 1 milhão de hectares da floresta estadual já haviam sido derrubadas para cederem espaço às extensas lavouras (Taunay, 1935).

O café, ávido por terras férteis, foi o causador dos desmatamentos ocorridos em grande parte da região Sul e Sudeste do Brasil. A irradiação dos cafezais criou enormes distâncias entre as lavouras e o porto de Santos, fator condicionante à criação das ferrovias, que foram financiadas pelos próprios cafeicultores. Estas ferrovias, ao mesmo tempo que expandiam as fronteiras da cafeicultura e, conseqüentemente, da economia, promoviam a destruição da floresta, em função do estabelecimento das lavouras, ou do abastecimento das fornalhas das locomotivas (Guillaumon, 1989).

A queimada da floresta para a instalação dos cafezais foi a principal causa, mas não a única, do desflorestamento do século XIX. O comércio do café induziu o crescimento demográfico, urbanização, industrialização e a implantação das ferrovias (Taunay, 1935).

O Ciclo Industrial também foi marcado pela exploração da cobertura vegetal, pois o Brasil ingressou na Era Industrial extremamente carente de combustíveis fósseis e hidrocarbono. A indústria brasileira dependia, primordialmente, de seu enorme estoque de recursos vegetais nativos para ter combustíveis (Dean, 1987).

Neste período, a lenha era consumida principalmente para uso doméstico, abastecimento das ferrovias, por fabricantes de tijolos, telhas e cal, cervejarias e destilarias, engenhos e refinarias de açúcar, fábricas de cimento, curtumes, tinturarias, 
torrefações de café, beneficiadoras de mandioca, padarias, fábricas de sabão, velas, conservas, fósforos, cerâmicas, banha, vidro e chapéu (Dean, 1996).

Nenhuma indústria teve maior impacto sobre as reservas de lenha que a siderúrgica, que era o sustentáculo das indústrias de base. Até a metade do século XX, essas usinas provocaram a derrubada de 265 mil hectares de matas. No entanto, as ferrovias queimavam mais lenha que a indústria siderúrgica. Até 1950, ano em que as locomotivas a vapor começaram a ser substituídas pelas locomotivas elétricas e a diesel, o consumo anual de lenha era equivalente a 62 mil hectares de floresta (Souza, 1947).

No Brasil, um importante setor metalúrgico estava em crescimento. Em 1950, a demanda anual de matas para abastecerem as indústrias metalúrgicas em São Paulo, Minas Gerais e Rio de Janeiro pode ter chegado a 14 mil hectares (Osse, 1971).

Infelizmente, todos os ciclos econômicos estiveram escudados no extrativismo predatório da cobertura florestal do Brasil, sem a preocupação da sua reconstituição ou simplesmente reposição para futuras gerações (Siqueira, 1982).

Além de todos os problemas ambientais causados e incalculáveis, há os problemas sociais, sempre presentes, pois as relações de produção do capitalismo, que nunca foram a forma social adequada para o avanço das forças produtivas, entravam e deformam o progresso técnico-científico, resultando na degradação socio-econômica e cultural da população (Burlatski, 1987).

Hoehne (1942) alertava para a devastação das florestas brasileiras, que era praticada sem que qualquer lucro fosse auferido da madeira ou da lenha, ou seja, simplesmente para a limpeza do terreno, a fim de aproveitá-lo para pastagens ou para a incipiente agricultura rotineira: "O fogo substitui o trabalho de dezenas de homens e é empregado para destruir aquilo que em muitos lugares faz tanta falta, sendo que depois da destruição da mata, grandes superfícies permanecem inaproveitadas. A extração de palmitos (Euterpe edulis Mart.) na Serra do Mar, precede à derrubada das florestas".

$\mathrm{O}$ extrativismo para exportação não desapareceu no século $\mathrm{XX}$. O comércio de orquídeas continuou a crescer, juntamente com o de peles de animais. $\mathrm{Na}$ metade do século, caçadores comerciais em São Paulo pagavam impostos sobre cerca de 
250 mil peles de animais por ano. Os caçadores sem licença talvez tenham duplicado esse total (Magnanini, 1961).

As serrarias também se constituíam num problema sério. No nordeste de São Paulo e no norte do Paraná havia cerca de 1.500 serrarias em 1955. Nos anos 60, cerca de 1.700 serrarias no norte do Espírito Santo derrubavam os últimos grandes remanescentes da Mata Atlântica, explorando principalmente as madeiras de lei de espécies variadas (Leite, 1979).

Nesta época não havia IBAMA, e as gerências governamentais que deviam cuidar dos problemas florestais nada fizeram para evitar a ação dos madeireiros. É triste registrar que os governantes deste país só passaram a preocupar-se com este tipo de problema depois que as florestas praticamente desapareceram (Alvim, 1994).

A estrutura agrária herdada da Colônia e da escravatura sobreviveu às mudanças e deixou marcas profundas na mentalidade das nossas elites. Cem anos depois da Abolição, a distribuição da terra brasileira permanece a mesma. Em 1985, os 5\% maiores proprietários se apropriavam de $70 \%$ da área cadastrada, enquanto na outra ponta a metade dos estabelecimentos rurais (quase 3 milhões de minifúndios) ocupava 2,2\% da área (Hoffmann, 1989).

Estabeleceram-se no Brasil, durante o século XX, governos ditatoriais e neoliberais, regados de corrupção e violência, que favoreceram o roubo de nossas terras, dos nossos minérios e de nossas riquezas vegetais. Estes governos, permitiram a destruição de nossa indústria pelo imperialismo estrangeiro. A agricultura é abandonada, enquanto o povo passa fome. A educação é visivelmente destruída, diante de um povo analfabeto e cada vez mais miserável (Dirceu \& Palmeira, 1998).

Durante 500 anos, a Mata Atlântica proporcionou lucros fáceis, como papagaios, corantes, escravos, ouro, orquídeas e madeira para o aproveitamento de seus senhores coloniais e, queimada e devastada, uma camada imensamente fértil de cinzas que possibilitavam uma agricultura passiva, imprudente e insustentável, enquanto a população crescia cada vez mais e o capital acumulava. A presença dessa floresta primária ao longo do litoral brasileiro possibilitava à Colônia padrões de povoamento singularmente dispersos, títulos de terra bizarramente precários, exploração da terra 
sempre renovada e decadente, trazendo em seu curso, conflitos sociais, prepotência de uma classe latifundiária, relações econômicas primitivas e pobreza (Dean, 1996).

No Brasil, a devastação florestal ainda ocorre de forma acelerada. A Mata Atlântica já foi uma das grandes florestas do planeta, ocupando cerca de $15 \%$ do território brasileiro. Sua área original era de aproximadamente 100 milhões de hectares. Hoje restam apenas $8 \%$ da vegetação original, e por isso é considerada internacionalmente como uma das florestas tropicais mais ameaçadas de extinção do planeta (Ferri, 1980).

Para o Estado de São Paulo como um todo, o período de 1920 a 1934 testemunhara a mais rápida destruição das suas florestas, ou seja, mais de 300 mil hectares por ano. Na metade deste século, a floresta que originalmente cobria $81,8 \%$ do território estadual (20,45 milhões de hectares), tinha sido reduzida a 18\%. Em 1973, restavam apenas 8,3\% da área original (2,07 milhões de hectares). A previsão para o ano 2.000 é de que restem apenas 750 mil hectares das florestas paulistas, ou seja, $3 \%$ da área original (Victor, 1975).

O desmatamento na Mata Atlântica é um problema muito sério, pois este importante ecossistema apresenta uma alta taxa de endemicidade, e sua fragmentação tem levado à extinção um grande número de populações, espécies e comunidades de animais e vegetais (Mori \& Boom, 1981). Dos 33 centros de endemicidade existentes na América do Sul, 2 estão estabelecidos no sul do Brasil: o da Serra do Mar e o do Paraná (Cracraft, 1985).

O acelerado processo de fragmentação da Mata Atlântica tornou esta região uma das áreas de mais alta prioridade para a conservação biológica em todo o mundo. A maior parte dos fragmentos florestais que encontramos na Mata Atlântica sofreu algum tipo de perturbação antrópica, e as poucas exceções são áreas de acesso muito difícil e de topografia acidentada (Viana, 1990). 


\subsection{Os problemas da fragmentação de ambientes naturais}

Entre os problemas relacionados com o desmatamento estão o esgotamento dos estoques de madeira, que ainda é a fonte primária de energia de $3 / 4$ da população dos países em desenvolvimento, graves inundações, destruição acelerada do solo, desertificação gradativa, diminuição da produtividade da terra e a perda da biodiversidade (Perlin, 1992).

As causas fundamentais do desmatamento e da degradação das florestas são a pobreza, injusta distribuição das terras, políticas inadequadas de desenvolvimento, debilidade das instituições e o rápido crescimento populacional (FAO, 1989).

Ao derrubar as matas, o homem remove sistemas biológicos complexos, multiestruturados, extremamente diversificados e estáveis. Ao instalar a agricultura, coloca em seu lugar sistemas simples e instáveis. Reduzindo a diversidade e recobrindo vastas áreas com monoculturas, ocorrem flutuações drásticas em populações, com o surgimento de pragas capazes de alterar todo o precário equilíbrio (Partido dos Trabalhadores, 1989).

Com a destruição das florestas, as nascentes ficam totalmente secas ou se tornam menos abundantes, e os leitos dos rios, que ficam secos durante a maior parte do ano, se convertem em torrentes caudalosas, depois de cada chuva pesada. Sem a cobertura vegetal, as águas da chuva não encontram obstáculos no seu curso, e em vez do nível subir lentamente por infiltração progressiva, essas águas causam inundações repentinas e destrutivas (Humboldt \& Bonpland, 1852).

Sempre que as florestas desaparecem dos pontos estratégicos, onde atuam como fatores físicos e mecânicos, desviando os ventos absorventes ou rajadas frias, e exercendo controle sobre as descargas pluviais, os distúrbios climatéricos começam a manifestar sua ação nociva sobre a biota e a produção agrícola (Kuhlmann, 1942).

Dentre as conseqüências mais importantes da fragmentação de hábitats naturais está a diminuição da diversidade biológica existente nestes ambientes (Ab’Saber, 1992). 
O termo diversidade biológica serve para descrever a variedade de formas de vida, os papéis ecológicos que elas executam e a diversidade genética que contêm. Mas enquanto os cientistas discutem sobre as consequiências dos desmatamentos nas regiões tropicais sob a diversidade biológica, populações, espécies e comunidades ecológicas inteiras de valor imensurável são simplesmente perdidas (Wilcox, 1982).

A perda de populações geneticamente distintas dentro de uma determinada espécie é um problema tão grave quanto a extinção desta espécie. Uma vez que uma determinada espécie é reduzida a uma pequena população, a sua extinção total num futuro próximo se torna muito mais provável (Ehrlich, 1988).

As espécie mais propensas à extinção são aquelas presentes no topo da pirâmide, espécies com dificuldades de dispersão, espécies endêmicas, migratórias e com hábitos gregários (Terborgh, 1974).

As estimativas do potencial de extinção para o final deste século, nas regiões tropicais são de $15 \%$ para todas as espécies vegetais e de $2 \%$ para todas as famílias botânicas existentes (Simberloff, 1986).

A diminuição de uma área de floresta natural pode levar à diminuição exponencial do número de espécies e afetar a dinâmica de populações de plantas e animais existentes, podendo comprometer a regeneração natural e, conseqüentemente, a sustentação destas florestas (Harris, 1984).

Os fragmentos florestais são áreas de vegetação natural, interrompidas por barreiras antrópicas ou naturais, capazes de diminuir significativamente o fluxo de animais, pólen e sementes. Apesar da importância dos fragmentos florestais na conservação da diversidade biológica, a maior parte deles encontra-se abandonada e em acelerado processo de degradação (Viana, 1990).

O número de espécies que um fragmento florestal pode suportar e as suas respectivas taxas de extinção dependem do seu tamanho, da distância de uma fonte de povoamento e da estrutura do hábitat (MacArthur \& Whitmore, 1979).

As reservas de vegetação natural podem ser divididas em três categorias: Unidades de Preservação, com áreas superiores a 100 mil hectares, onde admite ser possível a preservação da natureza, mantidas pelo poder público e representadas pelas 
Reservas Biológicas e Parques Nacionais e Estaduais, assim como as Unidades de Conservação, com áreas entre 500 e 100 mil hectares, normalmente circundadas por áreas profundamente alteradas. A categoria mais crítica são as Porções Vestigiais de Hábitats, com áreas bastante reduzidas, entre 10 e 500 hectares, geralmente alteradas e mantidas por particulares, normalmente distribuídas entre áreas de agricultura, nas faixas ciliares de rios e represas, em grotas ou locais de difícil acesso (Almeida, 1982b).

A redução do índice de extinção a níveis aceitáveis, ou seja, menos que $1 \%$ da quantidade inicial de espécies em um século, requer reservas de tamanho substancial, na ordem de 260 mil hectares (Terborgh, 1975).

A fragmentação se torna um problema quando a migração está ausente e a qualidade do hábitat é muito pobre ou a área é muita pequena para sustentar populações viáveis. A fragmentação é consequiência das atividades humanas, e as áreas de vegetação natural que restaram encontram-se geralmente muito próximas de áreas com perturbação antrópica, como fazendas agrícolas e de exploração florestal, estando sujeitas a tensão excessiva de agentes externos como fogo, inseticidas e espécie invasoras (Jansen, 1986).

Os fragmentos florestais localizados num ambiente de intensa ação antrópica, assemelham-se às ilhas oceânicas, separadas dos continentes aos quais estiveram ligadas em outras épocas. Estas ilhas biogeográficas encontram-se em equilíbrio quando o número de espécies presentes represente um balanço entre imigração e extinção. A taxa de imigração é determinada pelo grau de isolamento da ilha: quanto mais isolada estiver a ilha, mais baixa será a taxa de imigração. A taxa de extinção está diretamente ligada ao tamanho da ilha, sendo que ilhas maiores hospedam mais espécies, tanto de animais como plantas, do que ilhas menores, e desta forma são menos vulneráveis à extinção (MacArthur \& Wilson, 1967).

Preston (1962), baseando-se nos estudos biogeográficos de ilhas, alerta para o perigo da manutenção de apenas pequenos fragmentos de vegetação natural. Estudos realizados por Terborgh (1974), Willis (1979) e Diamond (1984), indicam que pequenas ilhas suportam menos espécies do que as grandes. 
O tamanho do fragmento florestal exerce um efeito direto sobre a diversidade de espécies da avifauna (Ambuel \& Temple, 1983; Blake \& Karr, 1984; Lynch \& Whigham, 1984).

Estudos realizados por Forman et al. (1976) e Galli et al. (1976), utilizando a avifauna como indicador ecológico, apontam valores crescentes para a diversidade de espécies com o aumento da área florestal.

Levantamentos realizados por Willis (1979) em 3 fragmentos florestais de 1.400, 250 e 21 hectares no interior do Estado de São Paulo, mostraram que restavam apenas 202, 146 e 93 espécies de aves, respectivamente, correspondendo a 87,8\%, $63,5 \%$ e 40,4\% do provável status original, e que as aves não passeriformes, os grandes frugívoros e os grandes insetívoros são os mais afetados com a diminuição das áreas florestais.

Terborgh (1975), estudando o problema da competição entre as espécies nos diversos níveis da floresta, concluiu que uma manifestação freqüente destas interações competitivas é a compressão das zonas de alimentação. As espécies que são confinadas em estreitas zonas de alimentação tornam-se extremamente dependentes da forma precisa que a vegetação é estruturada.

A atenção dos conservacionistas geralmente é dirigida para as grandes formações florestais, como parques e reservas protegidas por lei ou simplesmente para espécies da fauna ameaçadas de extinção. Pouca atenção tem sido dada para a preservação e o manejo de pequenos fragmentos florestais e que hoje se encontram geralmente em propriedades particulares (Câmara \& Mittermeier, 1984).

Os fragmentos de vegetação natural, principalmente aqueles de tamanho reduzido, são de grande importância às pesquisas e trabalhos de manejo de fauna, buscando minimizar os problemas registrados e auxiliando na conservação das espécies animais (Almeida, 1982b).

O primeiro problema sério que se encontra numa área fragmentada é o efeito de borda, ou seja, o efeito das populações que estão ao redor. Estas populações tentam colonizar o fragmento, enquanto que as populações do fragmento também tentam colonizar esta área de transição. O efeito da colonização se propaga até o núcleo do 
fragmento. As populações ficam desorganizadas, pois a tensão ecológica é muito grande, havendo redução de populações devido ao fenômeno da consangüinidade (Almeida, 1995).

O efeito de borda é a influência de duas comunidades sobre suas margens adjacentes, ou bordas, afetando a composição e densidades das populações nessas áreas limítrofes (Hanson, 1962).

A faixa de vegetação entre essas duas comunidades tem características dos dois tipos de vegetação vizinhas bem como suas próprias, e portanto é mais rica em vida silvestre do que as comunidades de plantas adjacentes (Thomas et al., 1979).

$\mathrm{O}$ fragmento florestal pode atingir o equilíbrio independentemente do tamanho, devido a fatores estocásticos, eventos esporádicos e episódicos, dificultando as previsões para o futuro através de uma simples descrição. O equilíbrio depende das interações das espécies e da co-evolução que estão ligadas às taxas de migração, extinção e competição específica. (Case \& Cody, 1987).

Vários fragmentos florestais poderão levar a um aumento do número de espécies do que apenas um fragmento de igual ou maior tamanho que a soma destes fragmentos, devido ao favorecimento de ambientes diversificados (Simberloff \& Abele, 1982).

Geralmente, existe maior diversidade em um único fragmento grande, onde os impactos são menores, preservando uma área central suficientemente grande para manter populações naturais em equilíbrio (Cole, 1981).

A estrutura e a dinâmica dos fragmentos florestais podem ser afetadas por diversos fatores dentre os quais destacam-se história de perturbações, área, forma, tipo de vizinhança e grau de isolamento. Os fragmentos florestais devem ser vistos como o resultado de um processo histórico de perturbação da vegetação no qual inúmeros fatores interagiram ao longo do tempo. Para se entender a estrutura e dinâmica atuais de um fragmento, é importante reconstruir ao máximo a história da vegetação local. A área de um fragmento florestal representa uma forte correlação com a diversidade e estabilidade das comunidades de animais e vegetais, sendo que o número de espécies está freqüentemente relacionado à área abrangida (Viana, 1990). 
Os efeitos da forma dos fragmentos florestais sobre a diversidade biológica e a sustentação da floresta podem ser tão marcantes como os do tamanho. Fragmentos de área arredondada ou circular apresentam uma baixa razão borda/interior, enquanto fragmentos alongados apresentam uma alta razão borda/interior. A razão borda/interior é importante pois indica a fração da área do fragmento que se encontra sob o efeito de borda. Quanto maior for a razão borda/interior, maior é a fração do fragmento sujeita ao efeito de borda e maior é o grau de perturbação do fragmento florestal. Em fragmentos com alta relação borda/interior, a composição das comunidades de plantas e animais deve apresentar menor diversidade do que aquelas situadas em fragmentos com baixa relação borda/interior (Viana, 1990).

Após a fragmentação de uma floresta, ocorrem mudanças imediatas na quantidade de luz incidente sobre o solo, temperatura, umidade e velocidade do vento. Tais mudanças são mais pronunciadas na borda e diminuem na direção do interior da floresta. Com o aumento da incidência de luz na borda dos fragmentos, há um aumento das espécies vegetais pioneiras, especialmente dos cipós (Lewis, 1984).

Lovejoy et al. (1986), em pesquisa realizada na Floresta Amazônica, observaram que há uma diminuição significativa no número de indivíduos e espécies de aves a partir da borda para o interior da floresta.

A distância entre fragmentos, assim como o grau de isolamento e a diminuição das áreas naturais, dificultam a dispersão e reduzem o tamanho das populações. O tipo de vizinhança, a redução da área dos fragmentos e a alta relação borda/interior, contribuem para o aumento da pressão dos predadores, competidores, parasitas e doenças (Rolstad, 1991).

A vizinhança pode afetar profundamente a diversidade biológica e a sustentação dos fragmentos florestais. As áreas vizinhas de um fragmento florestal podem funcionar como fontes de propágulos invasores, de poluentes e de perturbação, como modificadores climáticos e barreiras para o trânsito de animais (Viana, 1990).

O grau de isolamento de um fragmento florestal, que pode ser considerado como a média das distâncias até os fragmentos mais próximos, pode afetar 
o influxo de animais, pólen e sementes e, portanto, a diversidade biológica e a dinâmica das populações de plantas e animais (Forman \& Godron, 1986).

Fragmentos isolados há muito tempo degeneram pela perda de animais polinizadores, dispersores e predadores, causando um desequilíbrio da flora e fauna (Whitmore, 1991).

Entre os representantes mais ameaçados de extinção pela fragmentação de áreas florestais estão as espécies maiores, como os gaviões, as aves cinegéticas (utilizadas na caça), como os tinamídeos (inhambus, macuco e azulona) e os cracídeos (aracuãs, mutuns, jacus e jacutinga), os grandes frugívoros, como os papagaios e tucanos, que vivem nas copas das árvores, e as espécies do estrato inferior da mata, que são maus colonizadores, como certos insetívoros terrícolas (Terborgh \& Weske, 1969).

A reprodução destas aves diminui ao longo dos anos e não compensa mais a mortalidade dentro da população, levando a espécie sucessivamente à extinção sem ocorrer eventos dramáticos como destruição de hábitats (Terborgh, 1980).

A medida em que uma população isolada se torna pequena, aumentam os riscos com a consangüinidade e perda da diversidade genética, tornando mais graves os problemas demográficos, conduzindo a população mais rapidamente para o vórtice da extinção (Gilpin \& Soulé, 1986).

A população mínima viável é aquela que se encontra próxima do vórtice de extinção e tem $99 \%$ de chance de sobreviver por 1.000 anos apesar dos previsíveis efeitos demográficos, ambientais e da estocasticidade genética, assim como a ocorrência de catástrofes naturais (Shaffer, 1981).

Entre os possíveis fatores que contribuem para a extinção de populações locais estão a raridade (baixa densidade), limitada habilidade de dispersão e adaptação, perda sucessional do hábitat, isolamento, deterioração genética (perda da heterozigoticidade, depressão da procriação e perda da plasticidade genética), hibridação, catástrofe, competição, predação, epidemia, coleta e caça furtiva, variação ambiental, distúrbio e destruição do hábitat (Soulé, 1983).

Outra causa importante da extinção demográfica é a flutuação ao acaso da população, que é proporcional a $1 / \sqrt{ } \mathrm{k}$, sendo $\mathrm{k}$ o potencial da capacidade do hábitat 
(May, 1973). Portanto, uma população de 100 indivíduos flutuará entre 90 e 110 (cerca de $10 \%$ ), enquanto uma população de 9 indivíduos flutuará entre 6 e 12 (cerca de 33\%).

A disfunção do comportamento social é um fator intrínseco que pode precipitar um repentino e fatal declínio em números de indivíduos. Espécies de animais que se alimentam em grandes grupos ou formam grandes congregações de procriação, parecem ser especialmente susceptíveis à epidemias e eventos catastróficos (Soulé, 1986).

Karr (1981), estudando a vulnerabilidade de espécies de pássaros na Ilha de Barro Colorado, no Panamá, concluiu que um importante fator correlato à extinção é a exigência aos recursos ou condições que flutuam com as estações do ano, estando a maioria das extinções relacionadas com estresses durante a estação seca.

\subsection{Correlações entre a vegetação e a fauna}

A vegetação é uma das características do meio mais importante para a manutenção dos animais. Intervenções na vegetação produzem efeitos diretos na fauna, pela redução, aumento ou alteração de dois atributos chaves, que são o alimento e o abrigo (Odum, 1985).

Desta forma, a composição da vida silvestre é alterada à medida que ocorrem mudanças na vegetação (Hall, 1980).

Mudanças na vegetação, sejam de origem natural ou antrópica, interferem diretamente na estrutura populacional da avifauna. Este fato pode ser constatado através das alterações na diversidade e densidade das aves, principalmente entre as espécies mais especialistas (Berndt, 1992).

As relações entre populações de aves e o seu hábitat têm sido fonte de estudo para diversos pesquisadores (MacArthur, 1964; Anderson, 1980; Novaes, 1980; Smith, 1980; Almeida, 1981; Toledo, 1993; Mason, 1996; Recher, 1997).

A estrutura da vegetação tem grande influência no hábitat das diferentes espécies e, conseqüentemente, na composição faunística do ecossistema, sendo que hábitats diferentes abrigam espécies diferentes (Alho \& Pereira, 1987). 
Muitas pesquisas foram realizadas, analisando populações da avifauna, de acordo com determinadas características da vegetação, como sucessão ecológica (Beckwith, 1954; Shugart \& James, 1973; Allegrini, 1997), área (Willis, 1979; Diamond, 1984), diversidade e densidade de espécies arbóreas (Novaes, 1978; Almeida, 1979; Szaro, 1980), número de estratos e área basal (Almeida, 1981; Schwager, 1984), estrutura vertical e densidade de copa (Dueser \& Brown, 1980), efeito de borda (Magro, 1988) e presença de sub-bosque (Almeida \& Alves, 1982b).

Uma característica muito importante é a sucessão ecológica, que é um processo natural caracterizado por substituições que se sucedem em um ecossistema depois de uma perturbação natural ou antrópica, até chegar a um estágio estável (Shaw, 1985).

A maior parte da vegetação das zonas tropicais do mundo é constituída por vegetação secundária, devido ao intenso ritmo de devastação das áreas primárias (Gomez-Pompa \& Wiechers, 1976)

Shugart \& James (1973), estudando uma comunidade de aves ao longo de uma sucessão ecológica, observaram que algumas espécies estão restritas ao ambiente florestal em estágio clímax, e que outras são representativas do estágio inicial ou de outro estágio intermediário. Geralmente, há um aumento do número de espécies, da diversidade e da densidade de aves ao longo da sucessão ecológica, mas algumas exceções ocorrem onde os valores máximos são encontrados em estágios iniciais ou intermediários e não na floresta madura.

Allegrini (1997), analisando a avifauna como possível indicador biológico dos estágios de regeneração da Mata Atlântica, observou que nos estágios intermediários havia maior diversidade e densidade de aves do que nos estágios inicial e avançado.

Em geral, a diversidade de animais aumenta durante a sucessão e atinge o máximo no clímax da vegetação. Esta regra é válida para situações em que a vegetação, ocupando uma área de extensão considerável, vem se mantendo no estágio clímax por algum tempo. Porém, a diversidade animal pode atingir um máximo muito antes do clímax da vegetação. Em áreas com vários estágios sucessionais, o esperado é que a 
diversidade animal seja mais elevada antes que toda a área atinja o último estágio sucessional. Neste caso, quando a maior parte da vegetação se aproximar do estágio clímax, a diversidade animal tenderá a diminuir (Bock \& Linch, 1970).

As características da vegetação que estão mais correlacionadas com a diversidade de aves em um determinado hábitat, são a presença de sub-bosque e a altura da floresta, que determina o número de estratos verticais (Motta Júnior, 1990).

A altura da floresta proporciona uma grande quantidade de nichos que abrigam uma diversidade de habitantes nos diferentes níveis da estratificação, tendo efeito direto na diversidade de aves (MacArthur, 1972).

A diversidade de aves está mais diretamente ligada à estrutura da floresta do que à quantidade de espécies vegetais existentes neste ambiente natural (Lebreton \& Choisy, 1991).

As florestas tropicais possuem um amplo gradiente de microclimas internos, favorecendo a sua ocupação horizontal e vertical (Whitmore, 1991).

$\mathrm{O}$ aumento da complexidade estrutural da vegetação em vários níveis verticais possibilita novas formas de exploração do ambiente, e o aumento do número de espécies de aves se dá principalmente pelo aparecimento de novas guildas alimentares e pelo aumento no número de espécies das guildas já existentes (Willson, 1974).

Alterações antrópicas sobre o ambiente natural da fauna implicam que o ambiente natural remanescente pode tornar-se pequeno demais para abrigar espécies que necessitam de grandes áreas para sobreviver. A fragmentação do ambiente natural afeta principalmente as espécies raras e de baixa densidade populacional (Sick, 1985).

Os padrões de raridade são explicados através de vários fatores, como a história evolutiva, distribuição de espaço, estrutura genética de cada táxon e intervenção humana (Goerck, 1997).

A diversidade e a densidade da fauna podem sofrer aumentos significativos em áreas menores, devido ao influxo de espécies generalistas (Lynch \& Whigham, 1984). 
A composição da comunidade de aves é produto do processo evolutivo. Cada espécie é dependente de determinadas características da vegetação e das interações biológicas que determinam onde ela poderá existir (MacArthur \& Whitmore, 1979).

A estrutura, as distâncias das árvores, os diferentes tipos de vegetação, assim como a disposição espacial dos elementos florestais que constituem a paisagem, determinam os padrões de movimento das aves e explicam grande parte da variação espacial no número e categorias das visitas nas árvores (Laborde \& Guevara, 1990).

As árvores atraem diferentes espécies de frugívoros dispersores, em função da quantidade de recursos que oferecem ou porque estes animais as utilizam como locais de descanso, nidificação ou refúgio (Arredondo et al., 1990).

Existe uma interação muito grande entre a vegetação e a fauna, sendo que a maioria das espécies arbóreas tropicais é polinizada por animais (Bawa et al., 1985).

Da mesma forma, a dispersão de sementes das espécies arbóreas tropicais está associada em muitos casos à interação com animais (Dário, 1994). Diversos levantamentos realizados em matas ciliares, têm mostrado alta predominância de zoocoria das espécies (Vasconcelos \& Motta Júnior, 1989).

As características do ambiente que mais importam variam de espécie para espécie devido às suas histórias evolutivas diferentes, pois em virtude de sua evolução passada, as espécies criam seus próprios ambientes (Lewontin, 1983).

$\mathrm{O}$ ambiente ecológico inclui tanto fatores bióticos quanto abióticos. $\mathrm{O}$ clima, salinidade, tipo do solo, disponibilidade de água e outras características físicas e químicas também são importantes, assim como outras espécies também, incluindo presas, predadores, agentes patogênicos, competidores e mutualistas, são parte importante do ambiente de cada espécie. Outros membros da espécie de um indivíduo, com os quais o indivíduo pode acasalar, competir por recursos ou interagir em vários contextos sociais, são também peças importantes de seu ambiente. Deste modo, as propriedades da população tais como densidade, proporção sexual ou composição genética podem se impor de modo decisivo sobre as perspectivas de cada indivíduo de sobreviver e de se reproduzir (Futuyma, 1992). 
Numa determinada área geográfica, a distribuição de cada espécie é irregular devido à variação espacial das características físicas, disponibilidade de recursos e interações com espécies competidoras, predadoras e parasitas. Espécies que possuem necessidades muito precisas, consistem geralmente de muitas populações pequenas que estão, com frequiência, amplamente separadas (Brussard et al., 1974).

A diversidade do meio implica na diversidade de ambientes, que possibilita uma correspondente diversidade de espécies animais (Cody 1974). Só nessas condições específicas conseguimos um equilíbrio ambiental (Odum, 1985), pois quanto mais diversificado o ambiente, menor o número de fatores limitantes (Bailey, 1984).

A troca que se efetua entre o organismo e seu meio depende primeiramente, de seu patrimônio genético e da adaptação de suas capacidades, o que determina sua valência ecológica e, finalmente, sua cota na participação social. A estas diversas funções correspondem o genótipo, o fenótipo, o cenótipo e, a longo prazo, o geobiótico. Cada um destes níveis de adaptação possibilita uma classificação mais ou menos complexa. (Dansereau, 1992).

O número de espécies está freqüentemente relacionado com a área abrangida, de acordo com a relação $S=c A^{z}$, onde $S$ é o número de espécies, $A$ é a área e $c$ e $z$ são constantes; $c$ é uma estimativa do número de espécies por unidade de área e z indica o número de espécies novas que surgiram com o aumento da área, sendo que $c \mathrm{e} z$ diferem entre regiões (Jarvis, 1993).

A teoria de biogeografia de ilhas (MacArthur \& Wilson, 1967) explica esta relação, fazendo notar que o número de espécies de uma determinada região será determinado pelo equilíbrio entre a taxa de extinção e a taxa de imigração de novas espécies para a área. Existe evidência de que as taxas de extinção são maiores em áreas pequenas, que suportam populações menores, do que as grandes áreas (Diamond, 1972).

Existem fatores complicadores na determinação do tamanho efetivo da população. Estudos podem determinar que o tamanho de uma população seja $N$, mas se alguns desses indivíduos não se reproduzirem, a população será, na verdade, menor do ponto de vista genético. Se apenas metade dos indivíduos de uma população de $N=50$ se reproduzir, a perda de heterozigosidade por geração $(1 / 2 N)$ será de $1 / 50$ ao invés de 
1/100. A população possuirá um tamanho $N e$ de 25 . É o $N e$ que determina a taxa de deriva genética. Um fator que pode reduzir o tamanho efetivo da população é uma proporção sexual desbalanceada. Se, por exemplo, os machos protegem haréns de fêmeas contra outros machos, os poucos machos que se reproduzem contribuem desproporcionalmente às gerações subseqüentes, podendo ocorrer aumento da deriva genética (Felsenstein, 1971).

As freqüências gênicas em cada subpopulação podem flutuar ao acaso até que um alelo se fixe e a variação genética no loco seja perdida, a menos que restaurada por mutação ou imigração. Este processo, conhecido como deriva genética, acontece em qualquer população finita, sendo mais rápido nas populações de pequeno tamanho (Kimura, 1983).

O tamanho efetivo da população será ainda mais reduzido se as gerações sobrepuserem de modo que os descendentes possam se acasalar com seus pais ou se o tamanho da população flutuar ao longo das gerações (Giesel, 1971).

Normalmente é bastante difícil a obtenção de informações suficientes sobre uma população natural, como distâncias de dispersão, proporção sexual efetiva, frequiência de acasalamento através das gerações, variância no sucesso reprodutivo, para que se possa medir o tamanho efetivo da população (Eisen, 1975).

A taxa de fluxo gênico influencia o tamanho efetivo da população. No entanto, estes dois parâmetros são muito difíceis de se estimar nas populações naturais, mas diversas abordagens diretas e indiretas têm sido empregadas. Algumas aves migratórias, por exemplo, apresentam fluxo gênico e tamanho efetivo menores que o seu poder de vôo poderia sugerir, porque elas retornam às vizinhanças de seus locais de nascimento (Greenwood \& Harvey, 1982).

Existem diversos modelos de fluxo gênico que correspondem às diferenças na estrutura da população, dentre os quais se incluem (Futuyma, 1992):

- Modelo "continente-ilha", no qual efetivamente existe um movimento unidirecional de uma população grande, "continental", para uma menor e isolada; 
- Modelo de "ilha", no qual a migração ocorre ao acaso entre um grupo de pequenas populações;

- Modelo de "alpondras", no qual cada população recebe migrantes somente de populações vizinhas;

- Modelo do "isolamento pela distância", no qual o fluxo gênico ocorre localmente entre os vizinhos, em uma população de distribuição contínua. A maioria dos modelos considera que o fluxo gênico ocorre em uma taxa aproximadamente constante em cada geração. É importante salientar que a quantidade de deslocamento geneticamente efetivo (medido pela taxa de fluxo gênico) é, com freqüência, muito menor que o movimento dos organismos, já que muitos destes não têm sucesso em se reproduzir após terem se estabelecido em outras populações. As interações (por exemplo, a territorialidade), assim como as vicissitudes físicas e biológicas, reduzem a probabilidade de acasalamento (Ross et al., 1964).

A taxa de fluxo gênico entre populações estabelecidas de uma mesma espécie é, com freqüência, bastante baixa e tem probabilidade de ser ainda mais baixa se os indivíduos imigrantes necessitarem competir com os residentes para sobreviver e reproduzir. Entretanto, a taxa de fluxo gênico efetivo entre populações de uma espécie pode ser consideravelmente maior do que sugere sua taxa média, se populações locais se extinguirem com freqüência e os sítios forem recolonizados por indivíduos retirados de diversas populações (Slatkin, 1981).

À medida que uma população recém-fundada cresce em tamanho, suas freqüências gênicas são uma mistura daquelas das populações de onde vieram os colonos e esses, por sua vez, irão contribuir para a composição genética de outras populações quando o processo se repete. Quanto mais elevada a taxa de extinção e recolonização, maior a taxa de fluxo gênico e menor a variância nas frequiências alélicas entre populações. Isto pode ter o efeito de reduzir o tamanho populacional efetivo e o nível de diversidade genética na espécie como um todo, porque o fluxo gênico age contrariamente, neste caso, à tendência da deriva genética de aumentar a diversidade genética total de uma espécie, pela fixação de diferentes alelos em diferentes populações (Maruyama \& Kimura, 1980). 
É improvável que as comunidades tenham um conjunto aleatório de espécies que por acaso a invadiram. Pelo contrário, parece que as interações entre as espécies permitem que algumas combinações persistam, enquanto que algumas espécies que não se adequam são excluídas. Uma razão para esta crença de que as comunidades estão organizadas é que as faunas que se adaptaram independentemente a ambientes similares em diferentes partes do mundo parecem, algumas vezes, similares por convergência, embora isto não seja sempre verdadeiro (Orians \& Paine, 1983).

Espécies aparentadas, numa mesma comunidade, parecem ser menos similares em sua utilização de recursos do que se as comunidades estivessem sido montadas ao acaso. Algumas combinações de espécies são estáveis, enquanto outras não o são, no sentido de que uma ou mais espécies serão capazes de invadir a comunidade ou se extinguirão se outra o fizer. Há evidência de que comunidades complexas, consistindo de muitas espécies, podem ser mais resistentes à invasão por outras espécies do que comunidades mais simples, com poucas espécies (Elton, 1958).

Outros fatores que favorecem a estabilidade de uma comunidade são complexos e pouco compreendidos. Certamente não se trata de que o aumento da diversidade de espécies automaticamente favorece a estabilidade. Os ajustamentos evolutivos de uma espécie à outra podem, algumas vezes, favorecer a estabilidade, mas, freqüentemente, não o fazem (May, 1973).

Devido às interações entre a vegetação e a avifauna, as aves constituemse em um excelente indicador ecológico para se registrar as alterações em ecossistemas florestais. Ocupando diversos nichos tróficos, a diversidade de espécies varia de acordo com a capacidade do ambiente na oferta de alimentos (Almeida, 1982a).

Vários autores defendem a utilização da avifauna no monitoramento de ambientes terrestres e aquáticos (Elkins, 1983; Appelquist et. al., 1984; Morrison, 1986; Gilbertson et al., 1987; Hudson, 1990; Walsh, 1990). Narayanyan \& Eapen (1971) e Morton et al. (1980) utilizaram a avifauna no monitoramento de áreas contaminadas por radiação nuclear. Reynolds (1979), Vickery (1988 e 1991) e Ormerod \& Tyler (1990) utilizaram a avifauna como indicadora da qualidade da água. 
Espécies de aves migratórias foram utilizadas como monitoras das regiões tropicais, quando houve uma queda considerável da procriação destas aves na América do Norte. Este fato foi muito importante, pois chamou a atenção para o problema do desmatamento das florestas tropicais (Robbins et al., 1989).

A avifauna vem sendo largamente utilizada como monitora de agentes contaminantes, como agrotóxicos organoclorados, organofosforados, carbamatos, piretróides, metais pesados, nutrientes inorgânicos e plástico (Fry et al., 1987).

Muitas pesquisas já foram realizadas utilizando diversas espécies da avifauna como bioindicadoras. As aves, por pertencerem geralmente ao topo da cadeia alimentar, podem ser particularmente utilizadas como monitoras de elementos que acumulam na cadeia, como os organoclorados, mas da mesma forma podem também ser sensivelmente afetadas a estes elementos tóxicos (Furness \& Greenwood, 1984).

Entre as vantagens da utilização das aves como bioindicadores, estão a conspicuidade, facilidade de serem observadas, serem bastante conhecidas e caracterizadas, com taxonomia e biologia geralmente bem definidas, extremamente móveis, podendo responder de forma rápida às mudanças ambientais no tempo e no espaço (Matarazzo-Neuberger, 1994).

Ao se considerar cada espécie de ave, deve-se conhecer bem a biologia de cada uma, pois existem espécies que apresentam baixas abundâncias naturais ou baixa conspicuidade, ou que apresentam grande variação de sua conspicuidade ao longo do ano e que, o não registro da mesma não indica a sua real ausência. O uso de espécies com estas características como indicadores de determinado fator ambiental deve ser criterioso. Quando registradas em um hábitat, podem fornecer informações importantes, mas quando não registradas, não permitem considerações seguras a respeito deste fator, a menos que sua inexistência seja realmente confirmada (Allegrini, 1997).

\subsection{Corredores de vegetação natural}

A fragmentação de uma área de vegetação natural cria barreiras para a dispersão dos organismos entre os fragmentos. O sucesso de tal evento depende da 
habilidade de dispersão e do comportamento migratório das espécies afetadas. Algumas espécies cruzarão estas barreiras com pequena ou nenhuma hesitação, dependendo da dimensão do terreno desfavorável. Outras espécies relutam em aventurar em hábitat não familiar. Muitos pássaros tropicais e borboletas têm prevenção em cruzar rios ou áreas desflorestadas, por inibições intrínsecas à dispersão (Ehrlich \& Ehrlich, 1981).

$\mathrm{Na}$ maioria das vezes, os fragmentos florestais encontram-se isolados, sem ligações com outras áreas de vegetação natural. Deve-se pensar numa integração destas áreas para a obtenção de maior biodiversidade local, pois é o que vai possibilitar a sustentação das populações de animais e vegetais existentes. Em qualquer ambiente estudado, é importante saber como se encontram os núcleos de dispersão. Se forem implantados corredores de vegetação natural interligando os núcleos de dispersão (fragmentos florestais), estes corredores poderão sofrer influência direta destes núcleos de dispersão (Almeida \& Dário, 1995).

Diversos trabalhos salientam a importância de corredores de vegetação natural interligando fragmentos florestais isolados, para facilitar a dispersão de insetos (Hill, 1995), pássaros (Newmark, 1991; Rich et al., 1994; Haas, 1995) e mamíferos (Downes et al., 1997).

Haas (1995) realizou pesquisas em 16 locais no Estado de Dakota do Norte, nos Estados Unidos, apresentando dados em padrões de movimentação de mais de 500 adultos de 3 espécies de pássaros migratórios, entre fragmentos de vegetação natural, sendo mais freqüente o movimento entre fragmentos conectados por corredores de vegetação natural do que entre fragmentos isolados.

Os corredores de vegetação natural ligando fragmentos devem ser utilizados como uma estratégia para mitigar os efeitos de áreas agrícolas e de plantios florestais sobre a fauna e a flora. Diversos fatores podem influenciar na utilização dos corredores, como a biologia, ecologia e história de vida das espécies, a real necessidade do corredor e dos fragmentos para a fauna, sua largura, a localização dos fragmentos e a pressão antrópica sobre eles (Lindenmayer, 1994).

Estes corredores podem complementar a cadeia de reserva existente, aumentando a área efetiva de hábitat para a fauna e com isso os vínculos entre a fauna e 
o hábitat. Porém, podem não ser efetivos para a conservação de todas as espécies e o estabelecimento delas não é a solução para todos os problemas da conservação da biodiversidade (Wilson \& Lindenmayer, 1996).

Downes et al. (1997) analisaram a utilização de corredores de vegetação natural, como possível hábitat para algumas espécies de mamíferos na Austrália. Comparando a abundância e diversidade de mamíferos em floresta, pasto e corredor de vegetação natural entre florestas, observaram que existe uma densidade total maior de mamíferos em corredores do que em florestas e pasto, indicando que estes corredores são hábitats importantes para diversas espécies animais.

Os corredores de vegetação natural podem ser definidos como hábitats que permitem o movimento de organismos entre fragmentos isolados, principalmente espécies vulneráveis à extinção. Devemos considerar na implantação destes corredores, às exigências das espécies, pois a sua habilidade para usar um corredor prosperamente é em parte dependente da sua largura e composição. Na maioria dos casos, a determinação da largura mínima do corredor será um cálculo empírico (Newmark, 1993).

A largura do corredor está diretamente ligada ao efeito de borda. As populações de animais que se encontram nos ambientes vizinhos poderão interferir drasticamente na área do corredor, sendo que os animais presentes neste ambiente reagirão, pois as populações são móveis, defendendo o território. Portanto, territórios localizados nas margens podem se ampliar para o interior do corredor, impedindo a passagem de outros animais em conflitos pela defesa da área (Almeida \& Dário, 1995).

Algumas espécies, principalmente as de borda, suportariam transitar em ambientes sem vegetação arbórea, mas quando se tem um plantio puro de Eucalyptus ou Pinus, por exemplo, isolando fragmentos, este se torna uma barreira muito forte, principalmente se não houver sub-bosque. Outro fato importante é a ligação de ambientes semelhantes, pois a ligação de ambientes diferentes favorecerá temporariamente apenas as espécies adaptadas aos dois ambientes (Almeida, 1995).

As características das espécies da fauna, assim como as da flora são muito importantes no sucesso do deslocamento. As espécies que se encontram confinadas em 
estreitas zonas de alimentação tornam-se extremamente dependentes da forma precisa que a vegetação é estruturada (Terborgh, 1975).

Há espécies que se translocam com muita facilidade e outras têm muita dificuldade. Este fato depende da susceptibilidade da espécie à competição. As espécies de borda, por exemplo, suportam muito a competição, mas as espécies florestais não são tão adaptadas. Há espécies que vivem em conflito constante, até se favorecendo disso, mas outras não suportam a tensão ecológica, pois estão adaptadas às condições únicas do ambiente em que vivem (Almeida \& Dário, 1995).

Os corredores são utilizados às vezes para aumentar a diversidade genética entre populações, mas podem também contribuir para a diminuição desta diversidade, pois a migração entre populações individuais pode acabar homogeneizando como um todo a metapopulação. Os corredores podem permitir a passagem de doenças, predadores e espécies exóticas entre fragmentos e comprometer a dinâmica de uma metapopulação (Simberloff, 1984).

Estudos realizados na Nova Zelândia comprovaram que os corredores de vegetação natural facilitavam a expansão de porcos selvagens entre fragmentos de floresta, mas ameaçavam o desenvolvimento de certas espécies animais, como um caracol arborícola. Há também exemplos de predadores, como algumas serpentes, que se utilizam dos corredores como ambiente de fácil captura de alimento, devido ao fluxo mais intenso de animais (Mann \& Plummer, 1995).

Muitos animais utilizarão os corredores entre fragmentos florestais, se estes estiverem disponíveis, mesmo aqueles corredores que se constituírem num estreito caminho e demasiadamente pobre em diversidade vegetal, pois estes corredores são necessários (Beier, 1995).

Os corredores podem se constituir num hábitat útil para diversas espécies, mas podem não ser uma solução completa para os problemas da fragmentação da floresta natural, como a conservação da biodiversidade (Spackman \& Hughes, 1995). 


\section{METODOLOGIA}

\subsection{Localização e descrição da área}

O presente estudo foi desenvolvido em área localizada na Fazenda Cachoeira, de propriedade da Companhia Suzano de Papel e Celulose, no Município de Paraibuna, Estado de São Paulo, Brasil, entre as coordenadas geográficas $23^{\circ} 31^{\prime} 21^{\prime \prime}$ e $23^{\circ} 32^{\prime} 36^{\prime \prime}$ de Latitude Sul e $45^{\circ} 39^{\prime} 33^{\prime \prime}$ e $45^{\circ} 41^{\prime} 54^{\prime \prime}$ de Longitude Oeste (Figura 01).

Os ambientes estudados foram:

- 2 fragmentos de vegetação natural denominados fragmento vermelho (FV) e fragmento amarelo (FA), possuindo respectivamente 46,92 e 26,38 hectares;

- corredor de vegetação natural (C) interligando os 2 fragmentos, com 4,28 hectares, $656 \mathrm{~m}$ de comprimento e largura variando de 36 a $120 \mathrm{~m}$;

- sub-bosque de plantio de eucalipto (SB) adjacente aos fragmentos de vegetação natural.

Os fragmentos de vegetação natural estão localizadas em fundo de vale, onde existe um córrego com largura entre 2 e $6 \mathrm{~m}$, que atravessa os fragmentos e o corredor por toda a extensão (Figura 02). Este córrego é um dos principais afluentes do Rio Paraitinga, da bacia hidrográfica do Rio Tietê.

O entorno da área estudada é formado por plantios de eucaliptos em diferentes idades onde, numa área adjacente ao fragmento amarelo, desenvolveram-se 
estudos no sub-bosque de um plantio de Eucalyptus smith com 17 anos de idade. Esta área pertence ao RIMA, denominação dada pela empresa, aos plantios de eucaliptos abandonados para que ocorra a regeneração do sub-bosque e sirvam como zona de proteção às áreas de preservação permanente.

A escolha da área e dos ambientes, foi baseada em trabalho realizado pelo Instituto de Pesquisas e Estudos da Vida Silvestre (1999), cujos resultados demonstram que aproximadamente $94 \%$ dos fragmentos existentes em empresa florestal localizada em região da Mata Atlântica, possuem área inferior a 50 hectares, representando cerca de $38 \%$ da área total de vegetação natural.

Hoehne (1941) descreve a região próxima ao Município de Paraibuna, quando de sua excursão científica à Serra do Mar, em 1940:

"Assim constatamos nas cercanias das antigas cidades de Paraibuna e Paraitinga, cercanias de terrenos exauridos, cobertos de arbustos e capins estranhos, em que as águas pluviais jamais deixam de exercer a sua nefasta e terrível ação erodente, arrastando os detritos, levando o humo, para atirá-los aos cursos dos córregos, ribeiros e rios, que, felizmente, correndo para o interior do nosso país, mais além inundando terrenos, os fertilizam. Graças a isto os terrenos do arqueano que constituem esse contraforte da Serra do Mar, como aqueles terrenos da Serra do Quebra Cangalhas, uma vez despidos da mata, rapidamente se tornam imprestáveis para a agricultura".

A região apresenta-se hoje, com vegetação natural principalmente nas áreas com relevo predominantemente declivoso e nos fundos dos vales. O limite da vegetação natural coincide ou encontra-se muito próximo aos limites dos parques e reservas da Serra do Mar. Verifica-se a presença de extensas áreas de pastagens e reflorestamentos com eucaliptos, muitas vezes nos domínios dos parques e reservas. Há também inúmeras propriedades agrícolas de pequeno e médio porte e áreas de extração de materiais para construção civil.

Em 1982, o Município de Paraibuna possuía 80.539,92 hectares, dos quais $11.532,56$ hectares $(14,32 \%)$ cobertos por matas e $4.562,47$ hectares $(5,66 \%)$ cobertos por capoeiras (Ogawa et al., 1982). 
Figura 01. Localização da região de estudo.

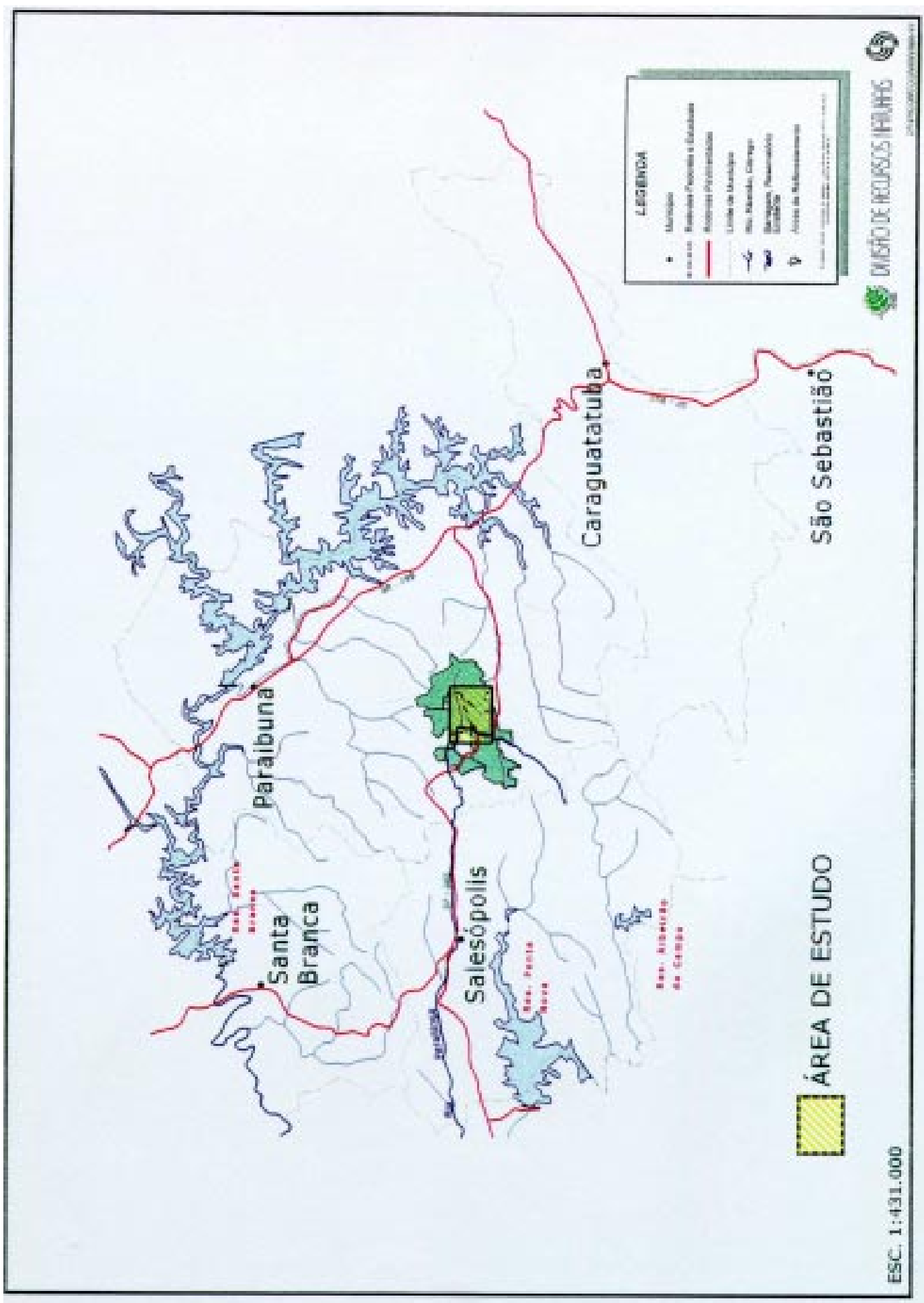


Figura 02. Localização dos ambientes estudados.

\section{Área de Estudo}

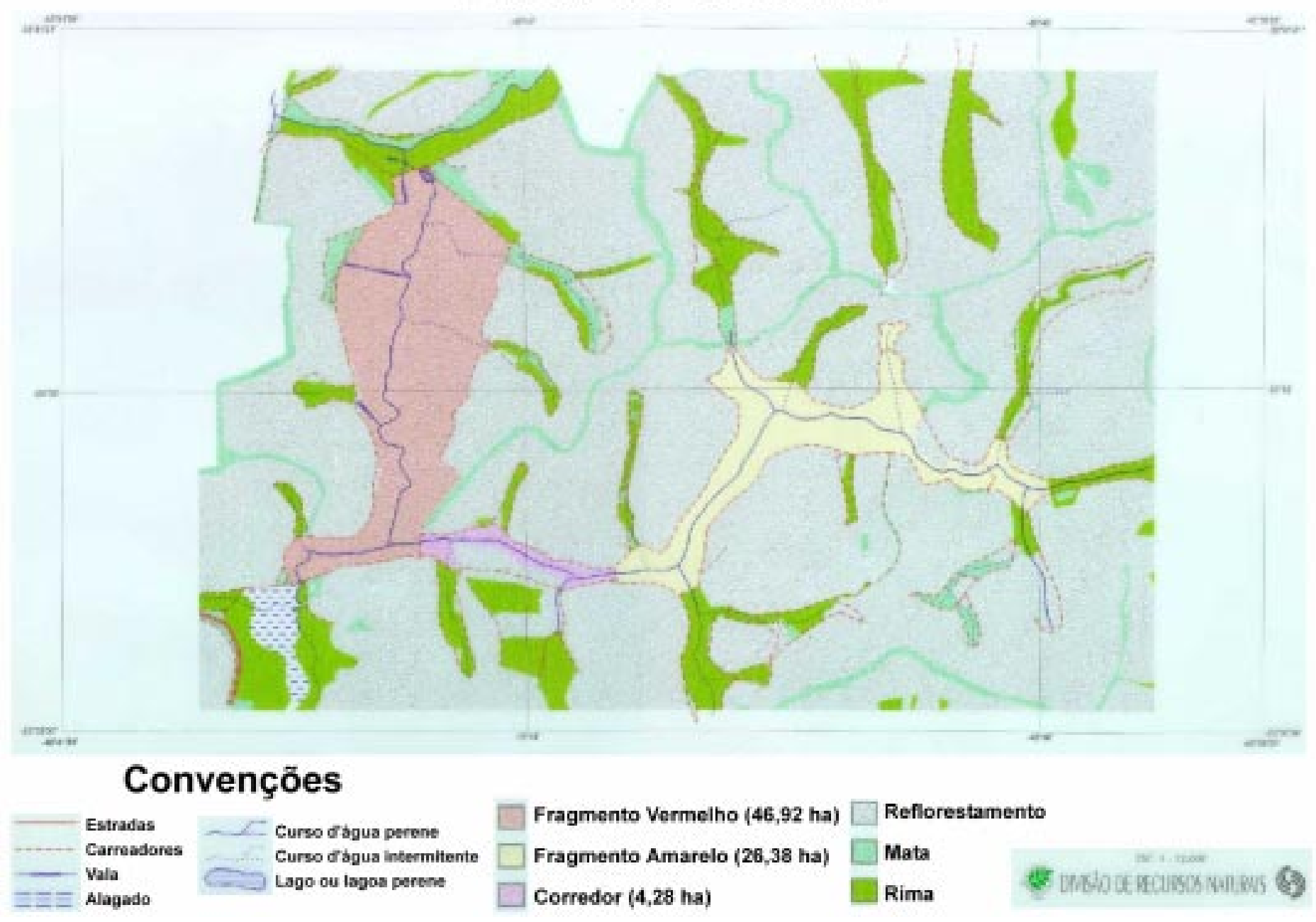




\subsection{Clima}

A área de estudo enquadra-se, segundo a classificação de Köppen, no tipo climático Cfa, com temperatura média do mês mais frio inferior a $18^{\circ} \mathrm{C}$ e a do mês mais quente superior a $22^{\circ} \mathrm{C}$, sendo o total de chuvas no mês mais seco (agosto) superior a 30 mm (Veiga, 1985).

A precipitação atmosférica na região está entre 1.400 e $1.500 \mathrm{~mm}$ anuais (Tabela 01). A estação seca ocorre entre os meses de abril e setembro, sendo os meses de junho, julho e agosto os de menor precipitação atmosférica $(9,4 \%$ da média anual) e também os mais frios, apresentando temperatura média de $15,5^{\circ} \mathrm{C}$. Entre os meses de outubro e março ocorrem $74,0 \%$ do total das chuvas. Os meses mais chuvosos são janeiro e fevereiro (32,2\% da média anual), sendo também os mais quentes, apresentando uma temperatura média de $23,5^{\circ} \mathrm{C}$ (Tabela 02).

Tabela 01. Valores mensais médios (méd), máximos (máx), mínimos (mín) e valores absolutos (va) da precipitação atmosférica ( $\mathrm{mm}$ ) do Município de ParaibunaSP no período de 1986 a 1996.

\begin{tabular}{rccrrrrrrrrrrr}
\hline & jan & fev & mar & abr & mai & jun & jul & ago & set & out & nov & dez & va \\
\hline méd & 246 & 227 & 188 & 75 & 82 & 44 & 54 & 40 & 87 & 166 & 101 & 159 & 1.469 \\
máx & 392 & 417 & 302 & 134 & 151 & 90 & 203 & 111 & 164 & 463 & 215 & 343 & 1.938 \\
mín & 113 & 71 & 92 & 0 & 34 & 5 & 4 & 0 & 4 & 78 & 54 & 0 & 1.171 \\
\hline
\end{tabular}

Fonte: Companhia Suzano de Papel e Celulose (1997)

Tabela 02. Valores mensais médios (méd), máximos (máx) e mínimos (mín) de temperatura $\left({ }^{\circ} \mathrm{C}\right)$ do Município de Paraibuna-SP no período de 1986 a 1996.

\begin{tabular}{rrrrrrrrrrrrr}
\hline & jan & fev & mar & abr & mai & jun & jul & ago & set & out & nov & dez \\
\hline méd & 23 & 24 & 22 & 20 & 17 & 15 & 15 & 16 & 17 & 20 & 20 & 22 \\
máx & 33 & 34 & 32 & 30 & 28 & 26 & 26 & 28 & 29 & 29 & 31 & 32 \\
mín & 12 & 13 & 12 & 11 & 7 & 3 & 3 & 3 & 6 & 10 & 9 & 11 \\
\hline
\end{tabular}

Fonte: Companhia Suzano de Papel e Celulose (1997) 


\subsection{Geomorfologia, geologia e solo}

A área de estudo está localizada na porção leste do Estado de São Paulo, correspondendo às bacias hidrográficas dos rios Paraibuna e Paraitinga. Esta região corresponde à província geomorfológica do Planalto Atlântico, e segundo a Divisão Geomorfológica do Estado de São Paulo, está inserida na zona do Planalto do Paraitinga e subzona da Morraria do Paraibuna (Instituto de Pesquisas Tecnológicas do Estado de São Paulo, 1981a).

O Planalto Atlântico caracteriza-se geomorfologicamente como uma região de terras altas, constituída predominantemente por rochas cristalinas précambrianas e cambro-ordovicianas, cortadas por intrusivas básicas e alcalinas mesozóico-terciárias, e pelas coberturas das bacias sedimentares de São Paulo e Taubaté (Monbeig, 1949).

O Planalto do Paraitinga é uma região drenada pela bacia do Rio Paraíba do Sul a montante de Guararema, estabelecendo-se às faldas do Planalto de Bocaina. Trata-se de um planalto cristalino de estrutura complexa, maturamente dissecado, com relevo de "mares de morros" e longas serras longitudinais (Almeida, 1964).

Na região de estudo, os morros são menores em área, e o relevo é caracterizado como Relevo de Morros Paralelos, com topos arredondados, vertentes com perfis retilíneos e convexos. A drenagem principal é muito encaixada e de alta densidade, com planícies aluvionares interiores restritas. A influência estrutural é marcante, traduzida pelo padrão em treliça da drenagem que é governada por sistemas de juntas e pela foliação das rochas, constituindo a Morraria do Paraibuna (Instituto de Pesquisas Tecnológicas do Estado de São Paulo, 1981a). A Fazenda Cachoeira, onde foi desenvolvido o presente estudo, está localizada na Serra dos Morais, com altitude variando de 944 a $1.136 \mathrm{~m}$ do nível do mar.

O Estado de São Paulo faz parte da Plataforma Sul-Americana (Almeida et al., 1976). A maior parte do embasamento da plataforma em sua porção paulista é 
constituída por rochas graníticas e granitóides, que possuem tipologias e características tectônicas variadas e encontram-se associadas aos diferentes compartimentos do précambriano paulista (Instituto de Pesquisas Tecnológicas do Estado de São Paulo, 1981b).

O controle litológico e estrutural no modelado do relevo é bem pronunciado em toda a Serra do Mar, na região do Vale do Paraíba, dependendo de estruturas mais desenvolvidas, como grandes falhamentos, ou dos tipos litológicos presentes, representados predominantemente por rochas cristalinas, como os migmatitos, granitos, xistos, gnaiss e quartzitos (Nakano, 1982; Prandini et al., 1982).

A área de estudo está localizada na Fácies Cantareira, que tem maior representatividade no pré-cambriano paulista, tanto no número de corpos quanto em área, havendo o predomínio de rochas do tipo granito-gnáissico, com a foliação concordante ao trend regional. Estas rochas possuem uma granulação fina e média, composição granítica a granodiorítica e ocorrência conspícua de megacristais de feldspato potássico, oriundos de uma metassomatose tardia, conferindo às rochas caráter porfiróide (Instituto de Pesquisas Tecnológicas do Estado de São Paulo, 1981b).

De acordo com o Boletim $\mathrm{n}^{\mathrm{o}} 12$ do Ministério da Agricultura (Brasil, 1960), o solo predominante na região é o PVL - Podzólico Vermelho Amarelo intergrade para Latossolo Vermelho Amarelo. Na nova nomenclatura, este solo é denominado Podzólico Vermelho Amarelo distrófico ou álico, Tb, A moderado e textura média/argilosa.

\subsection{Vegetação}

\subsubsection{Formação florestal}

A área de estudo está inserida na Serra do Mar, no domínio da Mata Atlântica, na formação florestal denominada Floresta Ombrófila Densa Atlântica, de acordo com o Mapa de Vegetação do Brasil (Instituto Brasileiro de Geografia e Estatística, 1988), na subdivisão Montana (Ellemberg \& Mueller-Dombois, 1966). 
Os ambientes da formação Montana da Floresta Ombrófila Densa Atlântica, ocupam os altos dos planaltos e serras nas faixas de altitude de 500 a $1.500 \mathrm{~m}$, sobre litologia pré-cambriana de modo geral ou alcalina cretácea de Itatiaia e da ilha de São Sebastião, ambas com o relevo dissecado, de caráter montanhoso. Ocorre também sobre litologia do paleozóico, em uma pequena porção da bacia do Rio Paraná, onde se consideram ombrófilas apenas as áreas com até 30 dias secos por ano, em virtude da reduzida capacidade de retenção de água de seus solos (Veloso, 1991).

A maior e mais contínua porção da vegetação remanescente pertencente a esta formação, está posicionada sobre os contrafortes ao longo de toda a Serra do Mar, desde o Município de São Paulo até o Município de Campos, no Estado do Rio de Janeiro, normalmente ocupando locais de difícil acesso, quase sempre constituindo áreas de preservação permanente (Veloso, 1991).

A vegetação da Floresta Ombrófila Densa Montana caracteriza-se por apresentar um estrato dominante com até $25 \mathrm{~m}$ de altura e grande diversidade em espécies arbóreas, como Vochysia laurifolia, Talauma organensis, Cariniana excelsa, Clethra brasiliensis, Ocotea spp, Nectandra spp, dentre as macrofanerófitas, e um estrato dominado de meso e nanofanerófitas de diversas espécies das famílias Rubiaceae, Myrtaceae e Melastomataceae, e presença generalizada de Arecaceae, Pteridophyta, Bromeliaceae e grande quantidade de epífitas e lianas (Projeto Radambrasil, 1983).

\subsubsection{Cobertura vegetal}

Foi realizado um levantamento florístico nos fragmentos e no corredor, durante as 4 estações do ano (verão, outono, inverno e primavera), ao longo do ano de 1997, buscando identificar as principais espécies vegetais de ocorrência nas áreas de estudo, caracterizando o estado de conservação destas áreas e a sua estrutura vertical.

Para todas as espécies vegetais que apresentavam flores e/ou frutos foram coletados materiais botânicos para herborização e posterior identificação em herbários. 
Na coleta foram utilizadas tesoura de alta poda acoplada em cabo de alumínio e tesoura manual.

As espécies vegetais foram agrupadas de acordo com a forma de vida (hábito de crescimento), as quais identificamos como arbusto, árvore, cipó, epífita, erva e palmeira.

Foram preenchidas fichas onde anotaram-se informações importantes como hábito, porte, aromas e cores das flores e dos frutos, para auxílio na identificação.

Os materiais botânicos coletados foram preparados para a secagem em prensas de sarrafos de madeira. Cada exemplar foi embalado em uma folha de jornal dobrada e intercalada com um conjunto de papelão e chapa de alumínio corrugado. Esse arranjo permite a circulação do ar e mantém o material botânico livre de umidade, evitando o ataque de fungos e permitindo uma secagem rápida.

As prensas foram colocadas em estufa do Departamento de Botânica da Escola Superior de Agricultura "Luiz de Queiroz", Universidade de São Paulo, para a secagem dos materiais botânicos, permitindo a secagem num tempo médio de 24 horas.

Os materiais botânicos, parcialmente identificados no campo, foram separados em família e através de bibliografia especializada e comparações com exsicatas existentes nos herbários ESA (Escola Superior de Agricultura "Luiz de Queiroz", Universidade de São Paulo) e UEC (Universidade Estadual de Campinas), foram identificados por espécie, segundo o Sistema de Classificação de Cronquist (1981), e apresentados em ordem alfabética na Tabela 03.

$\mathrm{Na}$ identificação parcial dos materiais botânicos foram utilizadas bibliografias ilustrativas, de sistemática e taxonomia vegetal, como Barroso (1978), Joly (1993) e Lorenzi (1986, 1992 e 1996). Os principais nomes comuns, apresentados no Anexo 03, estão de acordo com Corrêa (1984).

Foram identificados os locais de ocorrência de cada espécie, para obtenção do grau de homogeneidade dos ambientes estudados. Também foram caracterizados os perfis da vegetação dos fragmentos e do corredor, através da estratificação da fisionomia apresentada. 
Tabela 03. Lista das espécies vegetais identificadas nas áreas de estudo (FV $=$ fragmento vermelho, $\mathrm{C}=$ corredor, $\mathrm{FA}=$ fragmento amarelo).

\begin{tabular}{|c|c|c|c|c|c|}
\hline família & espécie & hábito & $\mathrm{FV}$ & $\mathrm{C}$ & FA \\
\hline Anacardiaceae & Schinus terebinthifolius Raddi & árvore & $\mathrm{x}$ & $\mathrm{x}$ & $\mathrm{x}$ \\
\hline \multirow[t]{2}{*}{ Annonaceae } & Guatteria nigrescens Mart. & árvore & $\mathrm{x}$ & $\mathrm{x}$ & $\mathrm{x}$ \\
\hline & Rollinia dolabripetala (Raddi) St.Hil. & árvore & $\mathrm{x}$ & & \\
\hline Apocynaceae & Aspidosperma parvifolium A.DC. & árvore & $\mathrm{x}$ & $\mathrm{x}$ & $\mathrm{x}$ \\
\hline \multirow[t]{3}{*}{ Araceae } & Anthurium sp & arbusto & $\mathrm{x}$ & $\mathrm{x}$ & $\mathrm{x}$ \\
\hline & Philodendron $\mathrm{sp}_{1}$ & arbusto & $\mathrm{x}$ & & \\
\hline & Philodendron $\mathrm{sp}_{2}$ & arbusto & $\mathrm{x}$ & $\mathrm{x}$ & $\mathrm{x}$ \\
\hline \multirow[t]{2}{*}{ Arecaceae } & Bactris setosa Mart. & palmeira & $\mathrm{x}$ & $\mathrm{x}$ & $\mathrm{x}$ \\
\hline & Syagrus romanzoffianum Mart. & palmeira & $\mathrm{x}$ & $\mathrm{x}$ & $\mathrm{x}$ \\
\hline \multirow[t]{7}{*}{ Asteraceae } & Baccharis dracunculifolia DC. & arbusto & $\mathrm{x}$ & $\mathrm{x}$ & $\mathrm{x}$ \\
\hline & Bidens pilosa $\mathrm{L}$ & erva & $\mathrm{x}$ & $\mathrm{x}$ & $\mathrm{x}$ \\
\hline & Emilia sonchifolia DC. & erva & $\mathrm{x}$ & $\mathrm{x}$ & $\mathrm{x}$ \\
\hline & Mikania sp & cipó & & $\mathrm{x}$ & \\
\hline & Piptocarpha axilaris Baker & arbusto & $\mathrm{x}$ & $\mathrm{x}$ & $\mathrm{x}$ \\
\hline & Vernonia polyanthes Less. & arbusto & $\mathrm{x}$ & $\mathrm{x}$ & $\mathrm{x}$ \\
\hline & Vernonia puberula Less. & arbusto & $\mathrm{x}$ & $\mathrm{x}$ & $\mathrm{x}$ \\
\hline \multirow[t]{4}{*}{ Bignoniaceae } & Arrabidea sp & cipó & $\mathrm{x}$ & $\mathrm{x}$ & $\mathrm{x}$ \\
\hline & Jacaranda $\mathrm{sp}$ & árvore & $\mathrm{x}$ & $\mathrm{x}$ & \\
\hline & Pyrostegia venusta Baill. & cipó & $\mathrm{x}$ & $\mathrm{x}$ & $\mathrm{x}$ \\
\hline & Tabebuia umbellata (Sond.) Sand. & árvore & $\mathrm{x}$ & $\mathrm{x}$ & $\mathrm{x}$ \\
\hline Boraginaceae & Cordia superba Cham. & árvore & $\mathrm{x}$ & $\mathrm{x}$ & $\mathrm{x}$ \\
\hline \multirow[t]{4}{*}{ Bromeliaceae } & Aechmea $\mathrm{sp}$ & epífita & $\mathrm{x}$ & $\mathrm{x}$ & $\mathrm{x}$ \\
\hline & Billbergia amoena (Lodd.) Lindl. & epífita & $\mathrm{x}$ & $\mathrm{x}$ & $\mathrm{x}$ \\
\hline & Tillandsia geminiflora Brong. & epífita & $\mathrm{x}$ & $\mathrm{x}$ & $\mathrm{x}$ \\
\hline & Tillandsia $\mathrm{sp}$ & epífita & $\mathrm{x}$ & $\mathrm{x}$ & $\mathrm{x}$ \\
\hline \multirow[t]{2}{*}{ Cactaceae } & Rhipsalis houlletiana Lem. & epífita & $\mathrm{x}$ & $\mathrm{x}$ & $\mathrm{x}$ \\
\hline & Rhipsalis sp & epífita & $\mathrm{x}$ & $\mathrm{x}$ & $\mathrm{x}$ \\
\hline \multirow[t]{2}{*}{ Caesalpiniaceae } & Bauhinia sp & cipó & $\mathrm{x}$ & $\mathrm{x}$ & $\mathrm{x}$ \\
\hline & Copaifera langsdorffii Desf. & árvore & $\mathrm{x}$ & $\mathrm{x}$ & $\mathrm{x}$ \\
\hline Cecropiaceae & Cecropia pachystachia Trec. & árvore & $\mathrm{x}$ & $\mathrm{x}$ & $\mathrm{x}$ \\
\hline Chrysobalanaceae & Hirtella glaziovii Taub. & arbusto & $\mathrm{x}$ & $\mathrm{x}$ & $\mathrm{x}$ \\
\hline Clethraceae & Clethra scabra Pers. & árvore & $\mathrm{x}$ & $\mathrm{x}$ & $\mathrm{x}$ \\
\hline Commelinaceae & Commelina virginica $\mathrm{L}$. & erva & $\mathrm{x}$ & $\mathrm{x}$ & $\mathrm{x}$ \\
\hline Convolvulaceae & Ipomea $\mathrm{sp}$ & cipó & $\mathrm{x}$ & $\mathrm{x}$ & $\mathrm{x}$ \\
\hline Elaeocarpaceae & Sloanea guianense (Aubl.) Benth. & árvore & & & $\mathrm{x}$ \\
\hline \multirow[t]{7}{*}{ Euphorbiaceae } & Alchornea glandulosa Poepp. \& Endl. & árvore & $\mathrm{x}$ & $\mathrm{x}$ & $\mathrm{x}$ \\
\hline & Alchornea triplinervia (Spreng.) Muell.Arg. & árvore & $\mathrm{x}$ & $\mathrm{x}$ & $\mathrm{x}$ \\
\hline & Croton floribundus Spreng. & árvore & $\mathrm{x}$ & $\mathrm{x}$ & $\mathrm{x}$ \\
\hline & Euphorbia brasiliensis Lam. & erva & $\mathrm{x}$ & $\mathrm{x}$ & $\mathrm{x}$ \\
\hline & Mabea fistulifera Mart. & árvore & $\mathrm{x}$ & $\mathrm{x}$ & $\mathrm{x}$ \\
\hline & Pera glabrata (Schott) Bail. & árvore & $\mathrm{x}$ & & \\
\hline & Sebastiania serrata (Baill.) Muell.Arg. & árvore & $\mathrm{x}$ & $\mathrm{x}$ & $\mathrm{x}$ \\
\hline
\end{tabular}


Tabela 03. Lista das espécies vegetais identificadas nas áreas de estudo (FV = fragmento vermelho, $\mathrm{C}=$ corredor, $\mathrm{FA}=$ fragmento amarelo).

\begin{tabular}{|c|c|c|c|c|c|}
\hline família & espécie & hábito & FV & $\mathrm{C}$ & FA \\
\hline \multirow[t]{2}{*}{ Fabaceae } & Machaerium aculeatum Raddi & árvore & $\mathrm{x}$ & $\mathrm{x}$ & $\mathrm{x}$ \\
\hline & Machaerium villosum Vog. & árvore & & & $\mathrm{x}$ \\
\hline \multirow[t]{2}{*}{ Flacourtiaceae } & Casearia decandra Jacq. & árvore & $\mathrm{x}$ & $\mathrm{x}$ & $\mathrm{x}$ \\
\hline & Casearia sylvestris $\mathrm{Sw}$. & árvore & $\mathrm{x}$ & $\mathrm{x}$ & $\mathrm{x}$ \\
\hline \multirow[t]{2}{*}{ Gesneriaceae } & Nematanthus fritschii Hoehne & erva & $\mathrm{x}$ & $\mathrm{x}$ & $\mathrm{x}$ \\
\hline & Nematanthus sp & erva & $\mathrm{x}$ & $\mathrm{x}$ & $\mathrm{x}$ \\
\hline \multirow[t]{3}{*}{ Lauraceae } & Nectandra lanceolata Nees & árvore & $\mathrm{x}$ & $\mathrm{x}$ & \\
\hline & Ocotea puberula Nees ex Mez. & árvore & $\mathrm{x}$ & & \\
\hline & Ocotea pulchella Mart. & árvore & $\mathrm{x}$ & $\mathrm{x}$ & $\mathrm{x}$ \\
\hline Malpighiaceae & Heteropterys sp & cipó & $\mathrm{x}$ & & \\
\hline Malvaceae & Sida cordifolia $\mathrm{L}$ & erva & $\mathrm{x}$ & $\mathrm{x}$ & $\mathrm{x}$ \\
\hline \multirow[t]{5}{*}{ Melastomataceae } & Leandra acutiflora Cogn. & arbusto & $\mathrm{x}$ & $\mathrm{x}$ & $\mathrm{x}$ \\
\hline & Miconia lurida Cogn. & arbusto & $\mathrm{x}$ & $\mathrm{x}$ & $\mathrm{x}$ \\
\hline & Miconia sellowiana Naud. & arbusto & $\mathrm{x}$ & $\mathrm{x}$ & $\mathrm{x}$ \\
\hline & Miconia $\mathrm{sp}_{1}$ & arbusto & $\mathrm{x}$ & $\mathrm{x}$ & $\mathrm{x}$ \\
\hline & Miconia $\mathrm{sp}_{2}$ & arbusto & $\mathrm{x}$ & $\mathrm{x}$ & $\mathrm{x}$ \\
\hline \multirow[t]{2}{*}{ Meliaceae } & Cabralea canjerana (Vell.) Mart. & árvore & $\mathrm{x}$ & $\mathrm{x}$ & $\mathrm{x}$ \\
\hline & Cedrela fissilis Vell. & árvore & $\mathrm{x}$ & $\mathrm{x}$ & $\mathrm{x}$ \\
\hline \multirow[t]{5}{*}{ Mimosaceae } & Anadenanthera colubrina (Vell.) Brenan & árvore & $\mathrm{x}$ & $\mathrm{x}$ & $\mathrm{x}$ \\
\hline & Inga sessilis (Vell.) Mart. & árvore & $\mathrm{x}$ & $\mathrm{x}$ & $\mathrm{x}$ \\
\hline & Mimosa scabrella Benth. & árvore & $\mathrm{x}$ & $\mathrm{x}$ & $\mathrm{x}$ \\
\hline & Parapiptadenia rigida (Benth.) Brenan & árvore & $\mathrm{x}$ & $\mathrm{x}$ & $\mathrm{x}$ \\
\hline & Piptadenia gonoacantha (Mart.) Macb. & árvore & $\mathrm{x}$ & $\mathrm{x}$ & $\mathrm{x}$ \\
\hline Moraceae & Ficus sp & árvore & $\mathrm{x}$ & & \\
\hline Myrsinaceae & Rapanea ferruginea (Ruiz et Pav.) Mez. & árvore & $\mathrm{x}$ & $\mathrm{x}$ & $\mathrm{x}$ \\
\hline \multirow[t]{7}{*}{ Myrtaceae } & Campomanesia guazumaefolia (Camb.) Berg. & árvore & $\mathrm{x}$ & $\mathrm{x}$ & $\mathrm{x}$ \\
\hline & Eugenia $\mathrm{sp}_{1}$ & árvore & $\mathrm{x}$ & $\mathrm{x}$ & $\mathrm{x}$ \\
\hline & Eugenia $\mathrm{sp}_{2}$ & árvore & $\mathrm{x}$ & $\mathrm{x}$ & $\mathrm{x}$ \\
\hline & Gomidesia affinis (Camb.) Legr. & árvore & $\mathrm{x}$ & $\mathrm{x}$ & $\mathrm{x}$ \\
\hline & Gomidesia spectabilis (DC.) Berg. & árvore & $\mathrm{x}$ & $\mathrm{x}$ & $\mathrm{x}$ \\
\hline & Marliera reitzii Legr. & árvore & $\mathrm{x}$ & $\mathrm{x}$ & $\mathrm{x}$ \\
\hline & Myrcia sp & arbusto & $\mathrm{x}$ & $\mathrm{x}$ & $\mathrm{x}$ \\
\hline Nyctaginaceae & Guapira opposita (Vell.) Reitz. & árvore & & $\mathrm{x}$ & \\
\hline \multirow[t]{5}{*}{ Orchidaceae } & Dichaea $\mathrm{sp}$ & epífita & $\mathrm{x}$ & $\mathrm{x}$ & $\mathrm{x}$ \\
\hline & Epidendron elongatum Jacq. & epífita & $\mathrm{x}$ & $\mathrm{x}$ & $\mathrm{x}$ \\
\hline & Epidendron ramosum Jacq. & epífita & $\mathrm{x}$ & $\mathrm{x}$ & \\
\hline & Epidendron rigidum Jacq. & epífita & $\mathrm{x}$ & $\mathrm{x}$ & \\
\hline & Oncidium flexuosum Sims & epífita & $\mathrm{x}$ & $\mathrm{x}$ & $\mathrm{x}$ \\
\hline Passifloraceae & Passiflora $\mathrm{sp}$ & cipó & & & $\mathrm{x}$ \\
\hline \multirow[t]{2}{*}{ Piperaceae } & Piper aduncum L. & arbusto & $\mathrm{x}$ & $\mathrm{x}$ & $\mathrm{x}$ \\
\hline & Piper arboreum Aubl. & arbusto & $\mathrm{x}$ & $\mathrm{x}$ & $\mathrm{x}$ \\
\hline Poaceae & Setaria geniculata (Lam.) Beauv. & erva & $\mathrm{x}$ & $\mathrm{x}$ & $\mathrm{x}$ \\
\hline
\end{tabular}


Tabela 03. Lista das espécies vegetais identificadas nas áreas de estudo (FV = fragmento vermelho, $\mathrm{C}=$ corredor, $\mathrm{FA}=$ fragmento amarelo).

\begin{tabular}{|c|c|c|c|c|c|}
\hline família & espécie & hábito & $\mathrm{FV}$ & $\mathrm{C}$ & FA \\
\hline Rosaceae & Rubus rosaefolius Smith & erva & $\mathrm{x}$ & $\mathrm{x}$ & $\mathrm{x}$ \\
\hline \multirow[t]{3}{*}{ Rubiaceae } & Alibertia concolor (Cham.) Schum. & arbusto & $\mathrm{x}$ & $\mathrm{x}$ & $\mathrm{x}$ \\
\hline & Amaioua guianensis Aubl. & árvore & $\mathrm{x}$ & $\mathrm{x}$ & $\mathrm{x}$ \\
\hline & Psychotria sessilis (Vell.) Muell.Arg. & arbusto & $\mathrm{x}$ & $\mathrm{x}$ & $\mathrm{x}$ \\
\hline Rutaceae & Zanthoxylum rhoifolium Lam. & árvore & $\mathrm{x}$ & $\mathrm{x}$ & $\mathrm{x}$ \\
\hline \multirow[t]{3}{*}{ Sapindaceae } & Matayba juglandifolia Radlk. & árvore & $\mathrm{x}$ & & \\
\hline & Paullinia sp & cipó & $\mathrm{x}$ & $\mathrm{x}$ & $\mathrm{x}$ \\
\hline & Serjania sp & cipó & & & $\mathrm{x}$ \\
\hline \multirow[t]{3}{*}{ Solanaceae } & Capsicum flexuosum Sendt. & arbusto & $\mathrm{x}$ & $\mathrm{x}$ & $\mathrm{x}$ \\
\hline & Solanum sp & arbusto & $\mathrm{x}$ & $\mathrm{x}$ & $\mathrm{x}$ \\
\hline & Solanum americanum Mill. & erva & $\mathrm{x}$ & $\mathrm{x}$ & $\mathrm{x}$ \\
\hline Sterculiaceae & Walteria indica $\mathrm{L}$ & erva & $\mathrm{x}$ & $\mathrm{x}$ & $\mathrm{x}$ \\
\hline Tiliaceae & Luehea grandiflora Mart. et Zucc. & árvore & $\mathrm{x}$ & $\mathrm{x}$ & $\mathrm{x}$ \\
\hline Ulmaceae & Trema micrantha (L.) Blume & árvore & $\mathrm{x}$ & $\mathrm{x}$ & $\mathrm{x}$ \\
\hline \multirow[t]{3}{*}{ Verbenaceae } & Aegiphilla sellowiana Cham. & arbusto & $\mathrm{x}$ & $\mathrm{x}$ & $\mathrm{x}$ \\
\hline & Cytharexylum myriathum Cham. & arbusto & & $\mathrm{x}$ & $\mathrm{x}$ \\
\hline & Lantana camara $\mathrm{L}$ & arbusto & $\mathrm{x}$ & $\mathrm{x}$ & $\mathrm{x}$ \\
\hline Zingiberaceae & Hedychium coronarium Koen. & erva & $\mathrm{x}$ & $\mathrm{x}$ & $\mathrm{x}$ \\
\hline
\end{tabular}

\subsubsection{Estrutura da paisagem}

A área de estudo, compreendida pelos 2 fragmentos florestais (Figuras 04, 05, 06 e 07) e o corredor de vegetação natural interligando-os (Figuras 08 e 09), é uma mata ciliar de um córrego que atravessa toda a sua extensão. Todo o entorno é formado por plantios de eucalipto em diferentes idades (Figura 10).

Esta mata ciliar encontra-se em estágio médio de regeneração secundária, apresentando as mesmas características fisionômicas e composição florística bastante semelhante nas 3 áreas de vegetação natural, com fisionomia arbórea e arbustiva predominando sobre a herbácea, constituindo estratos diferenciados.

É grande a ocorrência de espécies pioneiras antrópicas, como a Parapiptadenia rigida e a Mimosa scabrella, supostamente devido aos incêndios ocorridos no passado. No entanto, houve ao longo dos anos, a regeneração natural de toda a área, com um aumento da diversidade biológica. Hoje a área encontra-se com uma estrutura muito semelhante às grandes áreas de vegetação natural adjacentes. 
Através do levantamento florístico foram identificadas 102 espécies vegetais, agrupadas em 84 gêneros e 45 famílias. De acordo com o hábito de crescimento destas espécies, foram identificados 23 arbustos, 45 árvores, 9 cipós, 11 epífitas, 12 ervas e 2 palmeiras.

Das 102 espécies vegetais registradas na área, 84 (82,35\%) são comuns aos 3 ambientes de vegetação natural.

As principais espécies vegetais arbóreas de ocorrência natural na área são Guatteria nigrescens, Tabebuia umbellata, Alchornea triplinervia, Croton floribundus, Sebastiania serrata, Ocotea pulchella, Mimosa scabrella, Parapiptadenia rigida e Gomidesia affinis.

A vegetação foi dividida em 4 estratos (Figura 03):

- Dossel:

Estrato superior da mata, com árvores emergentes distribuídas esparsadamente, atingindo até $25 \mathrm{~m}$ de altura. As principais espécies observadas neste estrato foram Aspidosperma parvifolium, Copaifera langsdorffii, Ocotea pulchella, Anadenanthera colubrina e Parapiptadenia rigida. Observa-se uma quantidade muito grande de epífitas das famílias Bromeliaceae, Cactaceae e Orchidaceae nos troncos destas árvores. Não há a formação de um dossel contínuo, o que garante uma boa penetração de luz que, associada a elevada umidade, favorece o desenvolvimento de musgos, liquens, epífitas e cipós no interior da mata.

- Subdossel:

Estrato composto por árvores com alturas entre 10 e $15 \mathrm{~m}$, com distribuição diamétrica apresentando amplitude moderada, com o predomínio de pequenos diâmetros, cobertura variando de aberta a fechada e diversidade muito grande de espécies, como Guatteria nigrescens, Syagrus romanzoffianum, Tabebuia umbellata, Cordia superba, Alchornea triplinervia, Croton floribundus, Mabea fistulifera, Machaerium villosum, Casearia sylvestris, Nectandra lanceolata, Cedrela fissilis, Anadenanthera colubrina, Mimosa scabrella, Parapiptadenia rigida, Piptadenia gonoacantha e Campomanesia guazumifolia. 
- Sub-bosque:

Estrato composto por indivíduos jovens das espécies arbóreas do dossel e subdossel, atingindo até $5 \mathrm{~m}$ de altura, e arbustos bem desenvolvidos, como Baccharis dracunculifolia, Vernonia polyanthes, Vernonia puberula, Miconia sellowiana e Myrcia sp, principalmente nas bordas e nas pequenas clareiras existentes na área.

- Herbáceo:

Estrato formado por pequenos arbustos e plantas herbáceas e uma grande quantidade de bromélias dos gêneros Aechmea e Billbergia, principalmente nas áreas onde há maior incidência de luz. O solo é coberto por uma boa camada de serapilheira.

Figura 03. Esquema do perfil da vegetação.

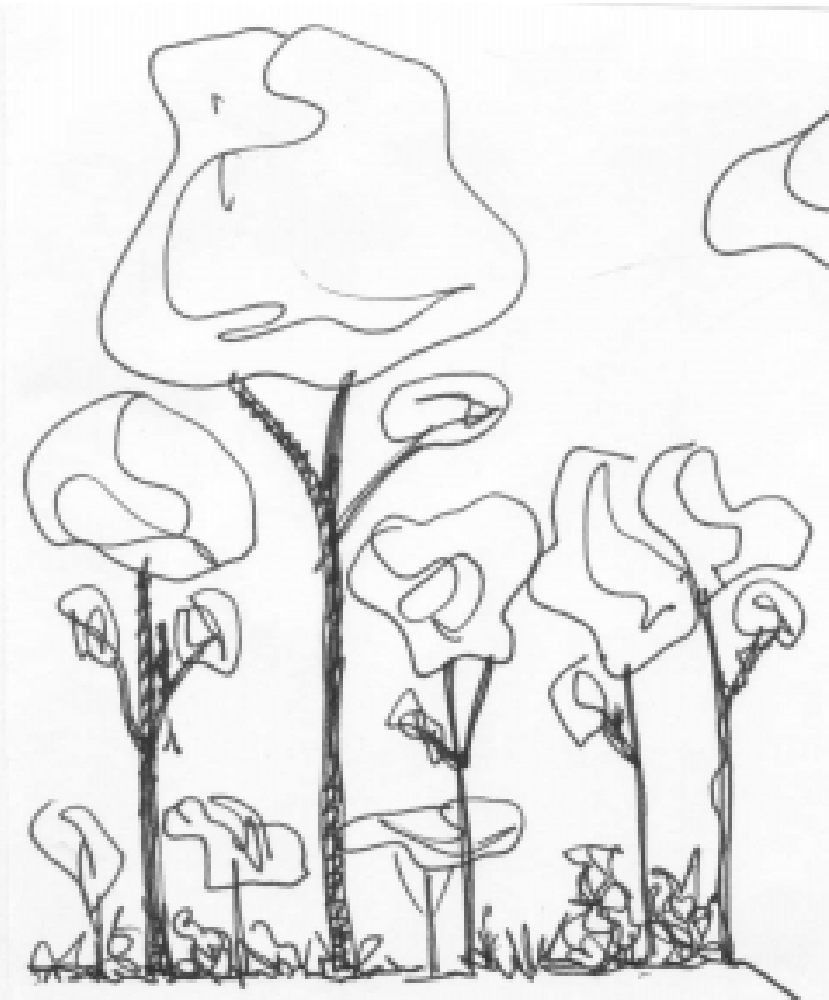




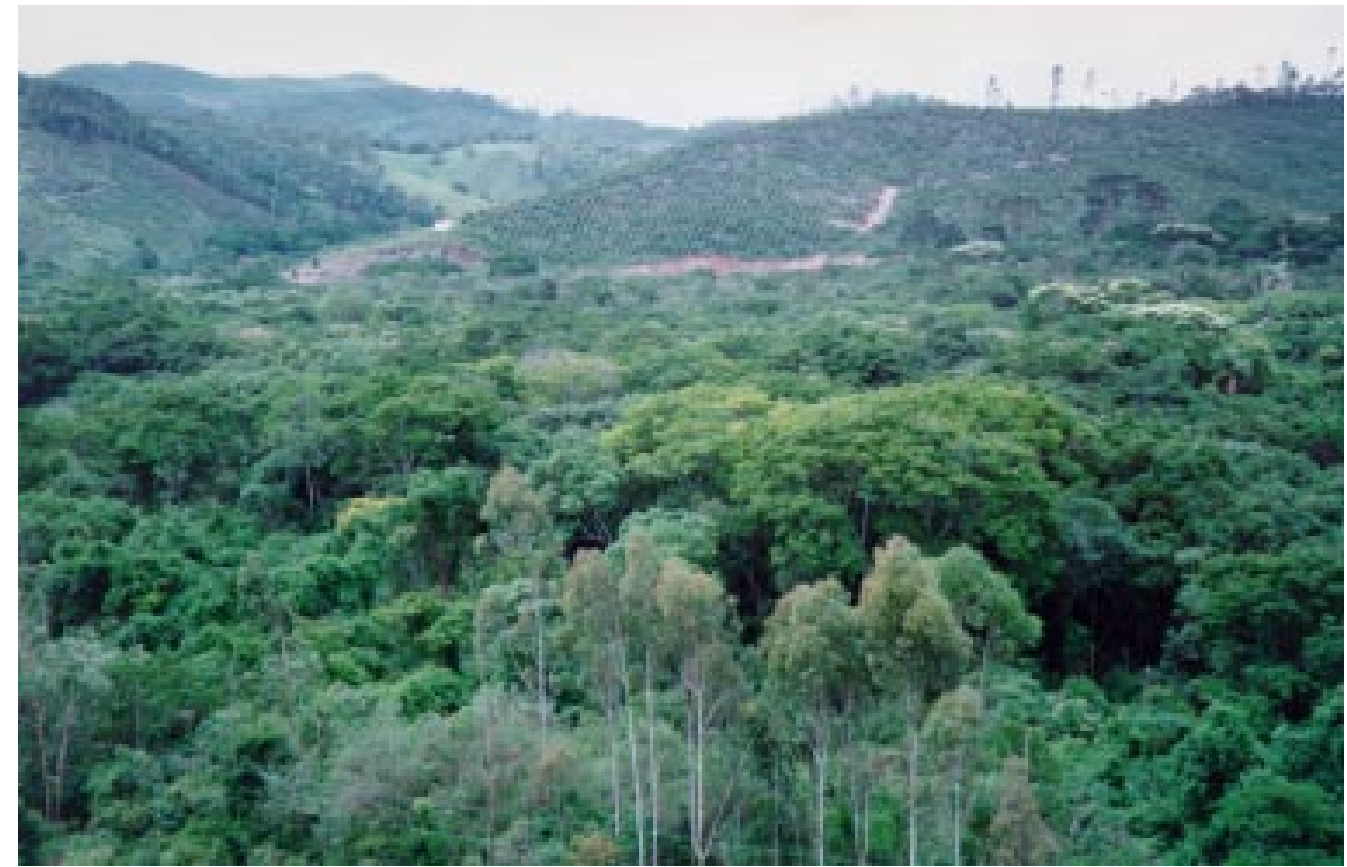

Figura 04. Vista parcial do fragmento vermelho (observar a distribuição da vegetação natural em fundo de vale) e dos plantios de eucalipto no entorno, em diferentes idades.

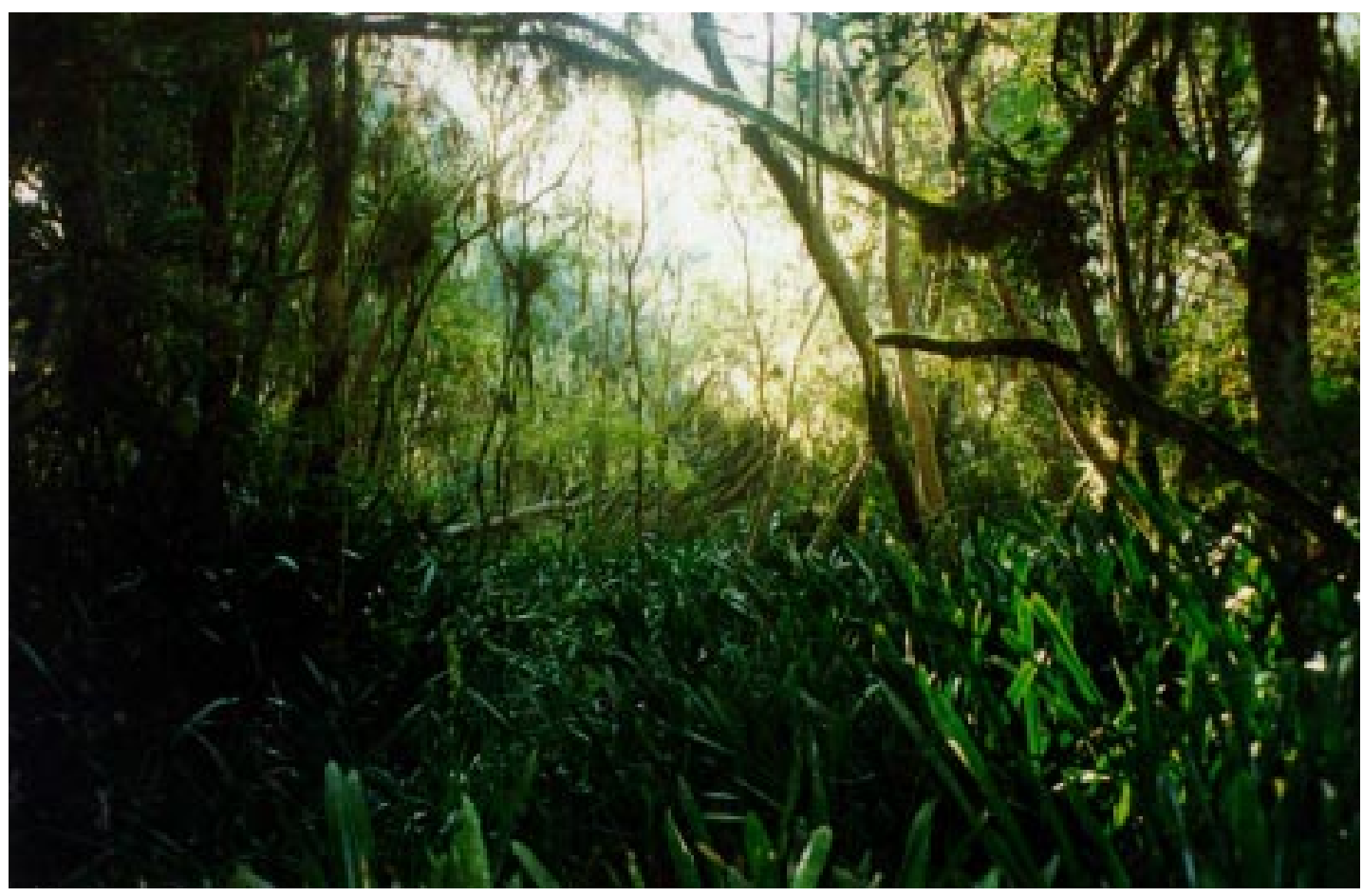

Figura 05. Detalhe do interior do fragmento vermelho (observar a quantidade de epífitas e o predomínio de pequenos diâmetros das árvores do subdossel). 


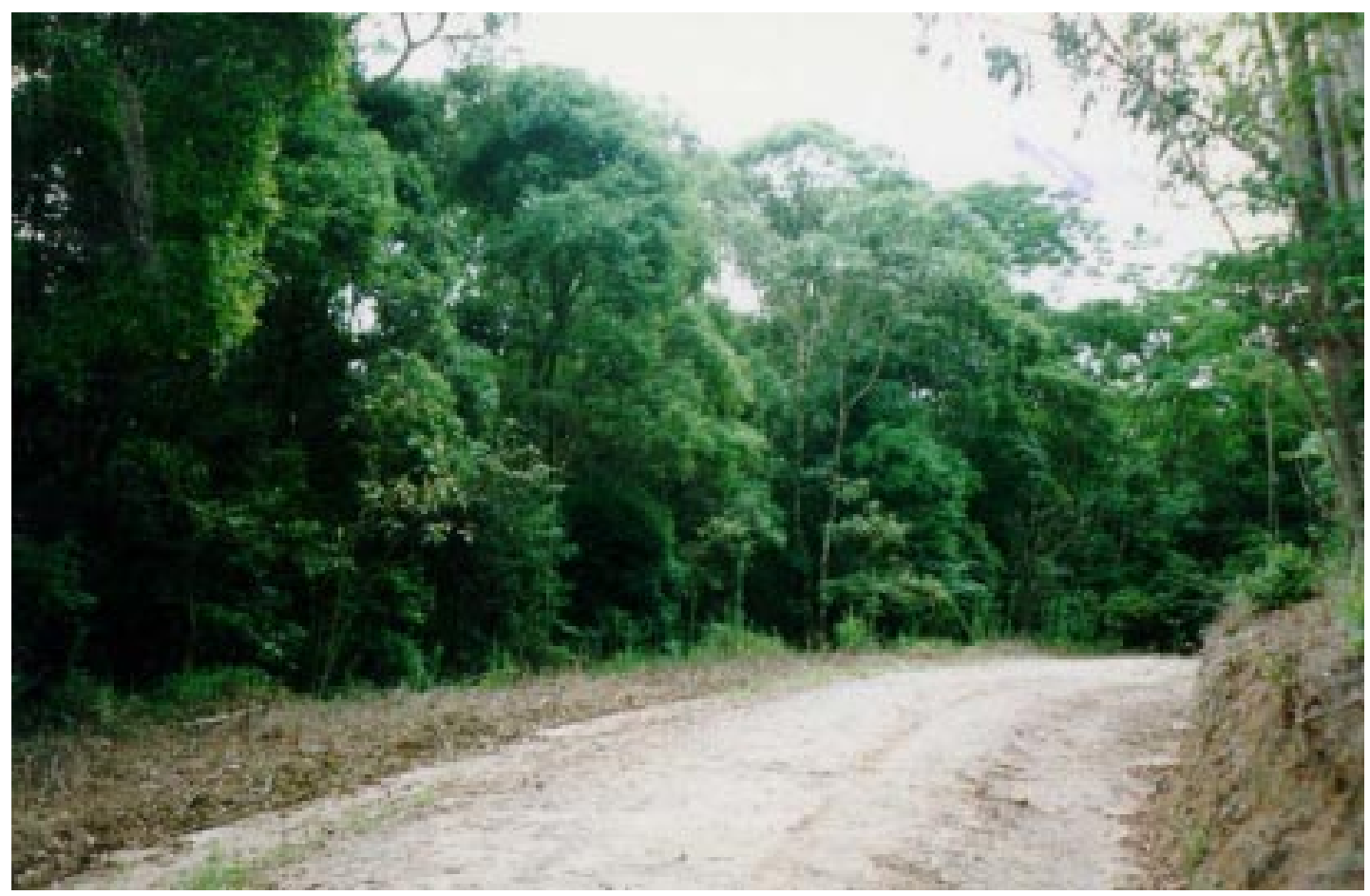

Figura 06. Vista parcial do fragmento amarelo (observar o perfil da vegetação, semelhante para as 3 áreas de vegetação natural).

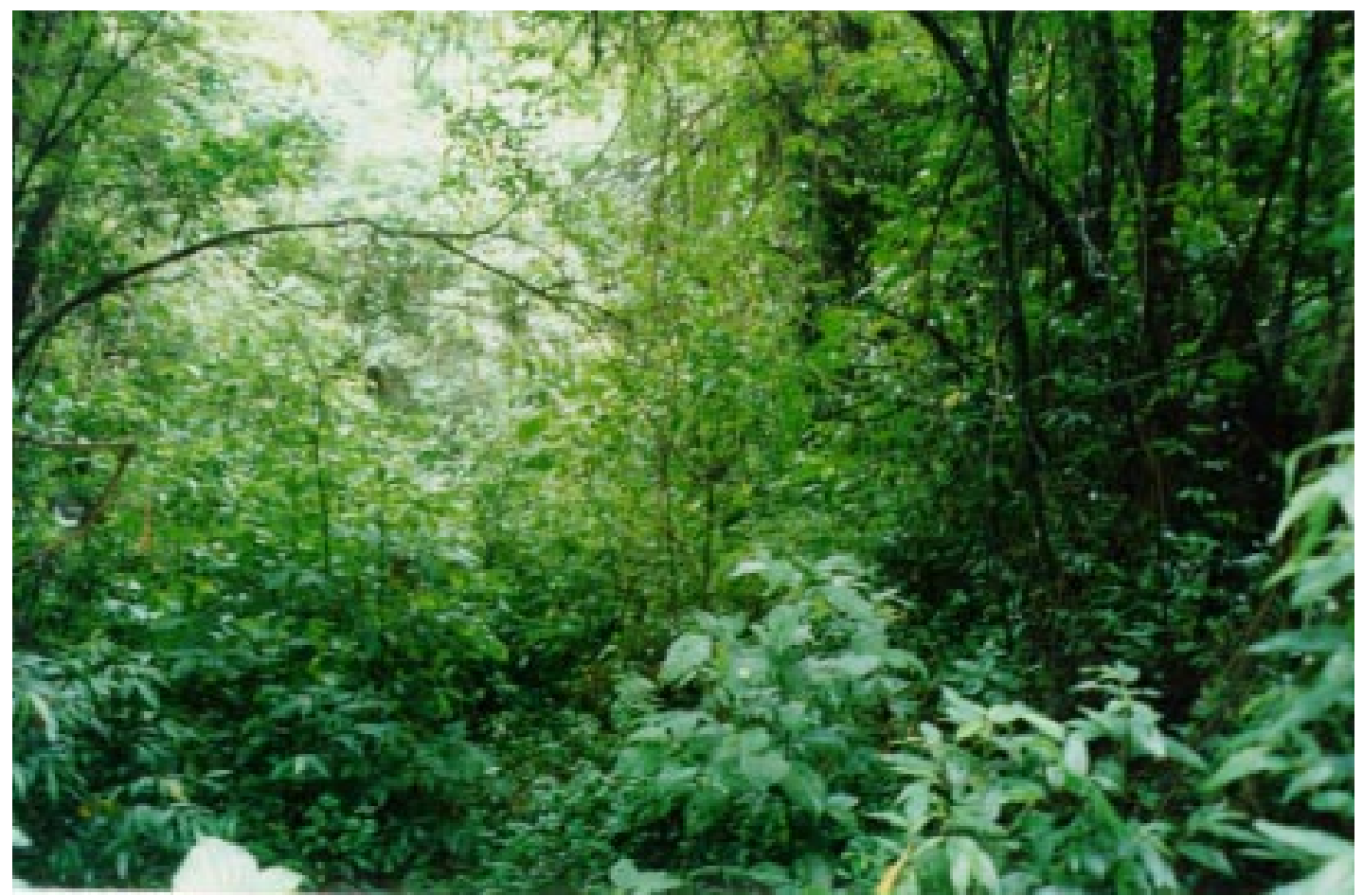

Figura 07. Detalhe do interior do fragmento amarelo (observar a boa intensidade de luz). 


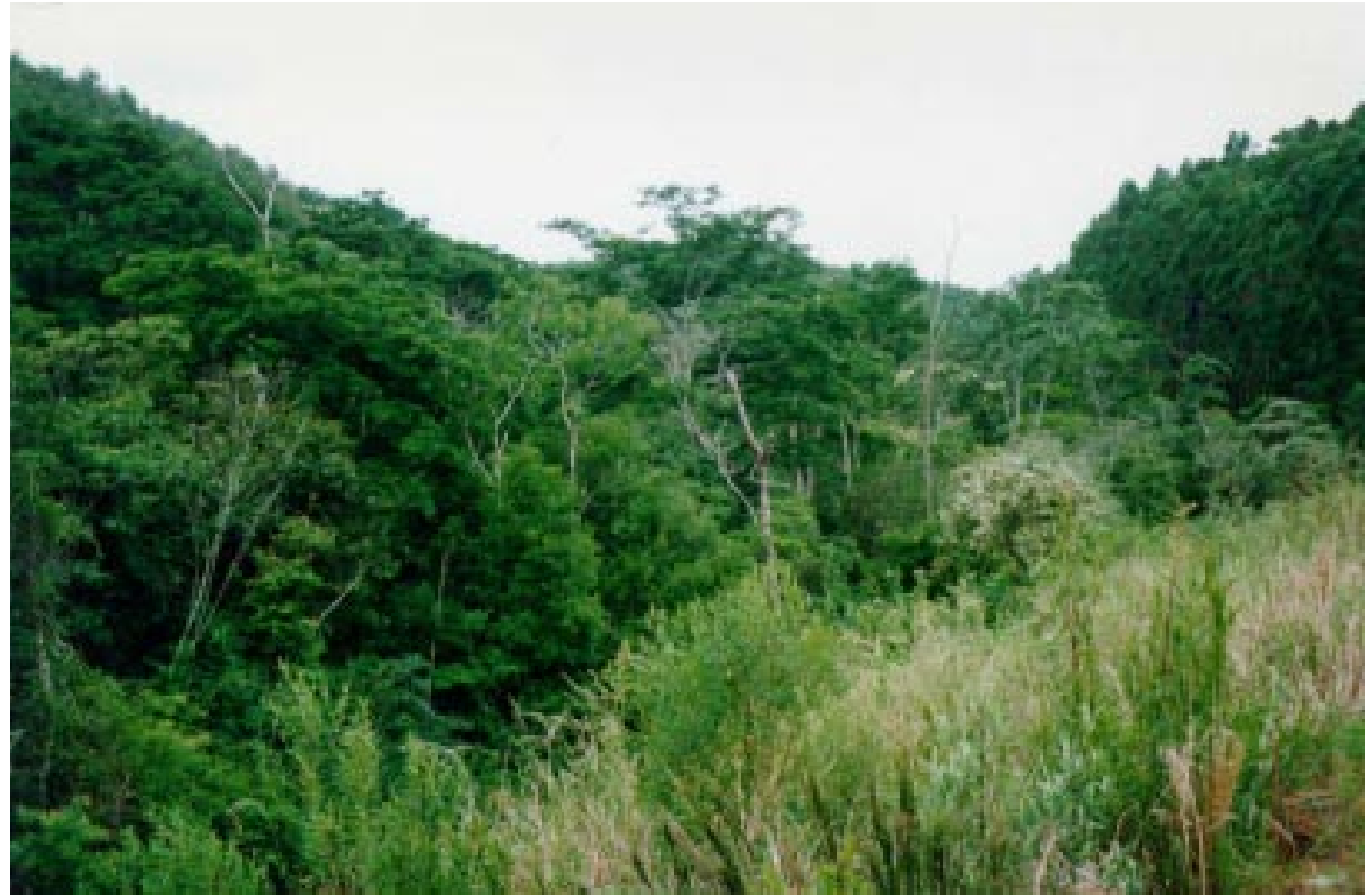

Figura 08. Vista parcial do corredor (observar o plantio de eucalipto no entorno).

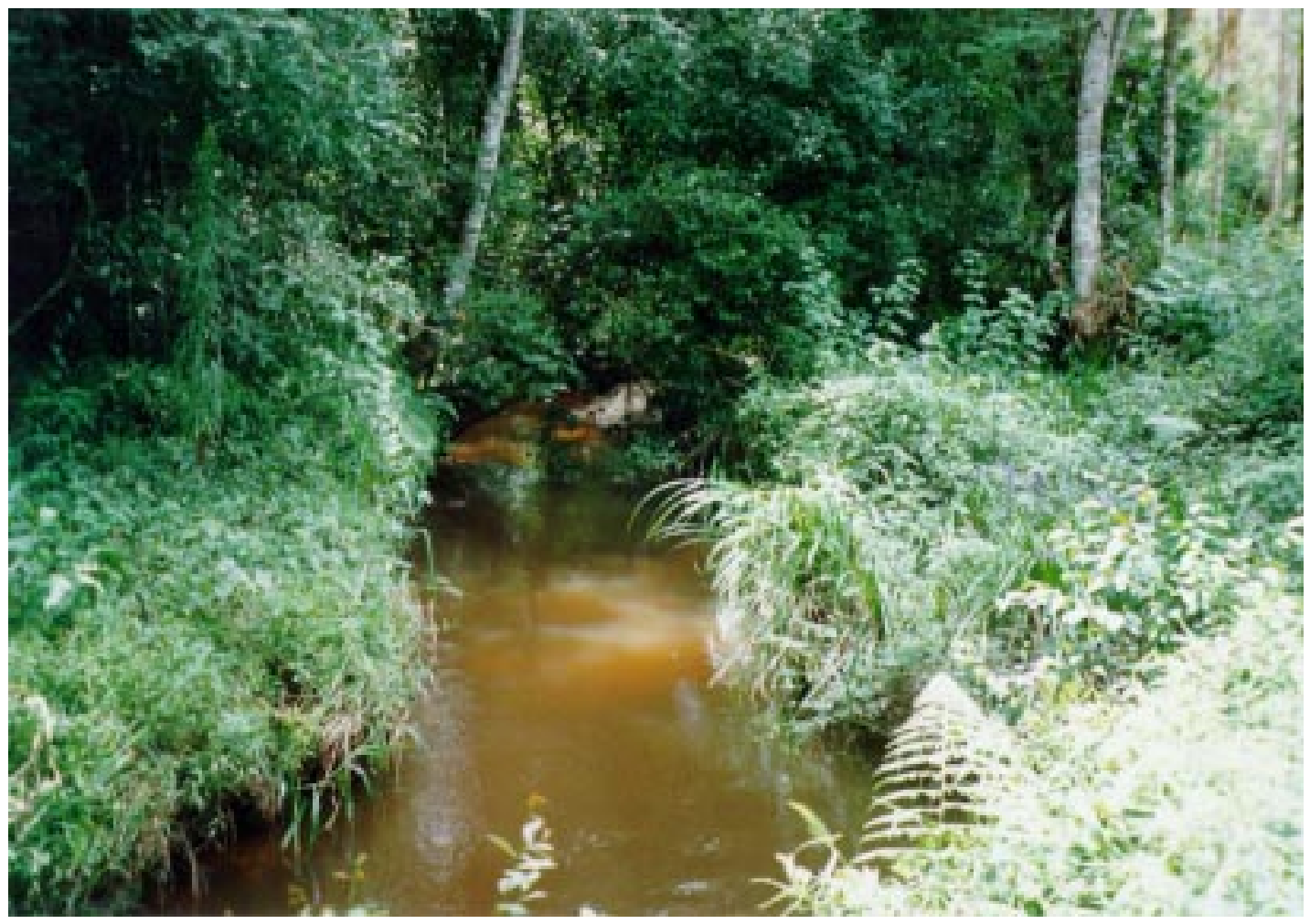

Figura 09. Detalhe do interior do corredor com o córrego (a não formação de dossel contínuo garante uma boa penetração de luz). 


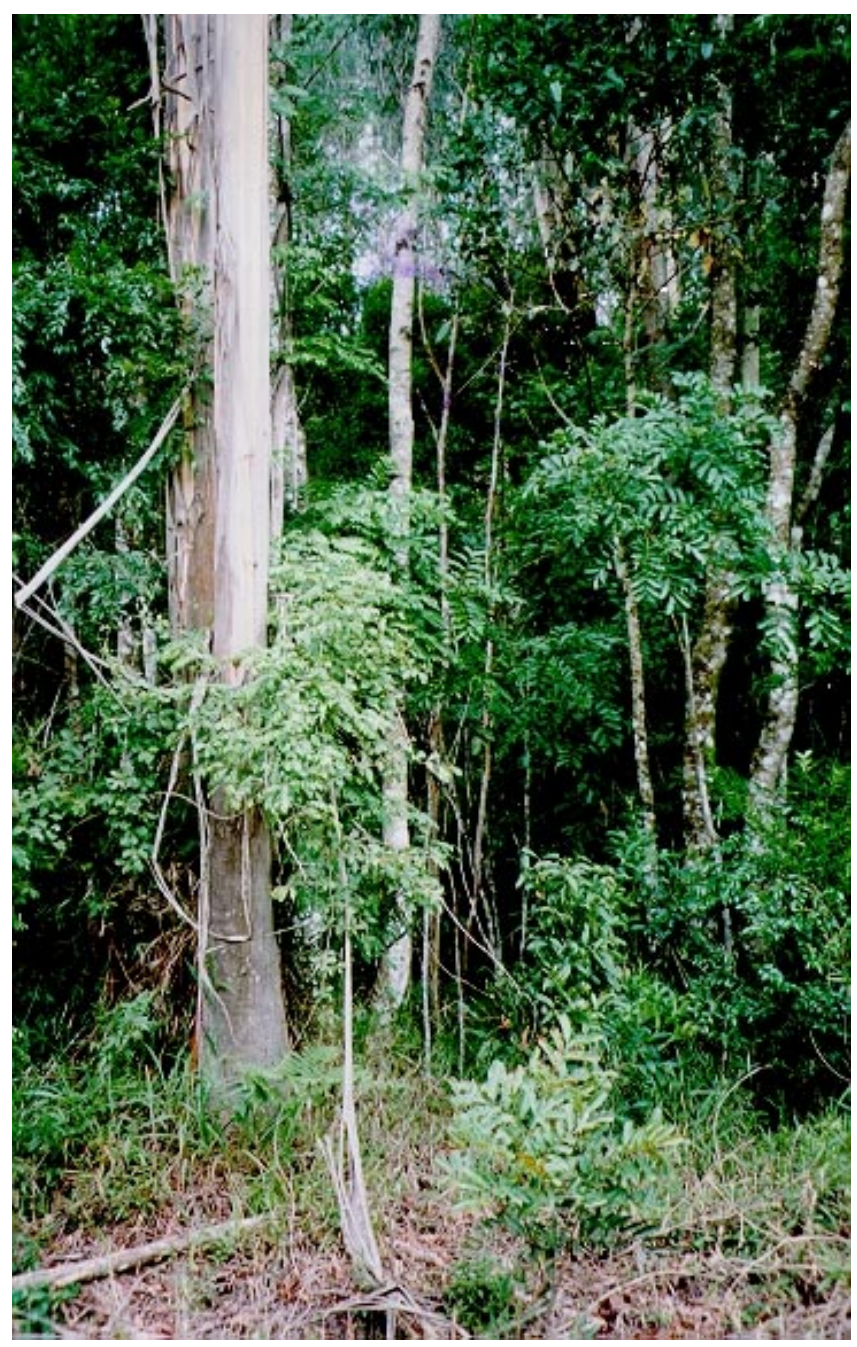

Figura 10. Detalhe do sub-bosque de eucalipto (observar o bom desenvolvimento de espécies arbóreas e arbustivas naturais da região). 


\subsection{Amostragem da avifauna}

\subsubsection{Métodos de amostragem}

Dentre os inúmeros métodos de amostragem da avifauna, a escolha do mais apropriado é fundamental, dependendo dos objetivos do estudo e do tipo de informações que se necessita (Karr, 1981). No entanto, tais métodos são dificultados em função da ecologia bastante variada que este grupo apresenta, principalmente quando trabalhamos em áreas florestais, devido à alta riqueza específica, complexidade e restrito campo visual (Anjos, 1992).

Devemos adotar uma combinação de métodos específicos de levantamentos de aves, procurando empregar métodos de captura e recaptura e de constatação visual e auditiva (Gonzaga, 1986).

O método de captura e recaptura utilizando redes neblina, permite ao observador conhecer alguns dados biológicos das aves, como sexo, idade, peso, época de reprodução, muda de penas, comprimento total do corpo, da asa e cauda (Instituto Brasileiro do Meio Ambiente e Recursos Naturais Renováveis, 1981).

A vantagem da utilização das redes neblina está no monitoramento a longo prazo das variações do ecossistema estudado, e os dados obtidos através deste método, que podem ser utilizados para cálculos refinados. Entretanto, fornece uma imagem parcial da comunidade (Vielliard \& Silva, 1989).

A principal vantagem deste método é que o uso das redes neblina não exige familiaridade com o canto das aves e nem com a sua localização e visualização. Além disso, as redes podem ser utilizadas para uniformizar o tamanho das amostras. A maior desvantagem, no entanto, consiste na dificuldade de seu uso nas copas e subcopas, em função da mobilidade, custos e dificuldade de uso (Karr, 1981).

Bierregaard (1990) aborda o fato das aves "marcarem" as redes ao longo da amostragem. Tal fato é constatado quando analisamos que, após o terceiro ou quarto 
dia de levantamento consecutivo, o número de indivíduos capturados diminui sensivelmente. Quando o intervalo entre levantamentos num mesmo local utilizando-se redes neblina, é superior a três semanas, parece não ocorrer o fato.

Outros fatores podem influenciar na captura das aves, como o período do levantamento, pois a atividade das aves é variável durante todo o dia, e a visibilidade das redes também varia em função da posição do sol, sendo também muito importante a padronização da hora do dia para realizar o levantamento (Karr, 1981).

No método de observações por pontos fixos, desenvolvido por Ferry e Frochot, estabelece-se uma rede de pontos no ambiente estudado, permanecendo o observador durante 20 minutos em cada ponto no período da manhã. Este método é aplicado principalmente na época do acasalamento, quando se torna bastante eficiente (Robbins, 1978).

Como o método de observações por pontos fixos objetiva obter a abundância de cada espécie, os pontos devem ser distribuídos e numerados de modo a cobrir uma amostra representativa da comunidade a ser analisada. Cada contato deve ser contado apenas uma vez, e esta metodologia deve ser empregada em comunidades de aves essencialmente florestais (Anjos, 1992).

Por ser um método basicamente visual e auditivo, os resultados obtidos são influenciados pelo fato de que nem todas as espécies possam ser detectadas na área de estudo. O grau de conspicuidade, sendo diferente para as espécies, e podendo variar mesmo dentro de uma mesma espécie de acordo com a época do ano, faz com que os índices de observação sejam empregados para comparar cada população, nas mesmas épocas do ano, em anos diferentes (Almeida, 1981).

Pelo fato do grau de conspicuidade ser diferente para as espécies, e poder interferir no resultado da amostragem, devem ser registrados apenas os indivíduos observados numa área delimitada, sendo esta suficiente para o registro visual ou por vocalização de todas as espécies de ocorrência no local (Scott et al., 1981). 


\subsubsection{Levantamento qualitativo}

Foi realizado um levantamento qualitativo prévio nas áreas de estudo e no entorno, visando uma adequação ao ambiente, procurando-se identificar as espécies da avifauna presentes, como recomendam Vielliard \& Silva (1989). Este levantamento completou a lista de espécies de aves obtidas pelos métodos quantitativos.

As observações foram realizadas nos períodos da manhã, fim de tarde, noite e nos intervalos dos métodos quantitativos, ao longo do ano de 1997.

\subsubsection{Levantamento quantitativo}

O levantamento quantitativo deu-se através dos métodos de observações por pontos fixos e de captura e recaptura, em 8 períodos de amostragens, nas 4 estações do ano (verão, outono, inverno e primavera), ao longo do ano de 1997.

$\mathrm{Na}$ abertura das trilhas para a instalação das redes neblina e dos pontos de observação, procurou-se causar o menor dano possível à vegetação, considerando-se uma largura suficiente, que permitisse a sua instalação e a posterior realização dos levantamentos.

O material bibliográfico utilizado na identificação da avifauna foi baseado nas publicações de Schauensee \& Phelps Jr (1978), Frisch (1981), Schauensee (1982), Ruschi (1986), Dunning (1987), Grantsau (1989), Narosky \& Yzurieta (1989), Vielliard (1994) e Sick (1997). Foram consultadas gravações realizadas pelo professor Jacques Vielliard, da UNICAMP - Universidade Estadual de Campinas e pelo pesquisador Johan Dalgas Frisch para a identificação das gravações de cantos.

A nomenclatura científica e ordem taxonômica estão de acordo com Sick (1997), que segue a disposição proposta por Schauensee (1966), a respeito da sequiência das ordens, subordens, famílias, subfamílias, gêneros e espécies. Os nomes comuns (Anexo 02) estão de acordo com Sick (1997). Os nomes dos descritores das espécies foram constatados em Mitchell (1957), Ruschi (1967), Dubs (1992) e Vielliard (1994). 


\subsubsection{Execução do levantamento quantitativo}

\subsubsection{Método de observações por pontos fixos}

As observações da avifauna foram realizadas em pontos fixos marcados com estacas de eucalipto numeradas, distantes no mínimo 50 m entre si e distribuídas aleatoriamente ao longo das trilhas abertas no interior dos fragmentos, corredor e subbosque de eucalipto.

A distância de $200 \mathrm{~m}$ entre pontos e a permanência de 20 minutos em cada ponto são adequadas para que não haja sobreposição de território de algumas espécies, e também por permitir uma boa amostragem da avifauna (Vielliard \& Silva, 1989).

A permanência de 20 minutos em cada ponto são importantes na floresta tropical, onde a avifauna é mais rica e há necessidade de maior tempo para a identificação das diferentes espécies. No entanto, em durações longas, é mais fácil registrar mais de uma vez as aves que se movimentam bastante (Fuller \& Langslow, 1984).

Para evitar a sobreposição de território, considerando-se a distância mínima adotada de $50 \mathrm{~m}$, dividiu-se cada ponto em 4 quadrantes, orientando-se com uma bússola e anotando-se os indivíduos observados de acordo com a sua localização dentro do quadrante, evitando-se desta forma, registrar o mesmo indivíduo 2 ou mais vezes. Em função da maior abundância de aves, não houve obrigatoriedade na utilização seqüencial dos pontos, aumentando-se neste caso, a distância entre os mesmos.

As aves que foram observadas sobrevoando, sem contudo pousarem nas proximidades, não foram registradas, pois sua dependência para com o local não pode ser constatada com segurança.

Foram realizados 20 minutos de observação em cada ponto, registrandose em fichas de campo, todos os indivíduos que podiam ser identificados com segurança, 
anotando-se a quantidade, horário, local de observação, quadrante, data e estrato arbóreo utilizado, além das condições meteorológicas locais.

As observações foram realizadas no período da manhã (das 06:00 às 11:00 horas) e nos fins das tardes (das 16:30 às 18:30 horas).

A identificação das aves foi feita visualmente, com o auxílio de binóculo $8 \times 25 \times 25$ e guias de campo, e auditivamente, com o auxílio de um gravador microcassete. As gravações de cantos, pios, chamadas, gritos de alerta e outras formas de vocalização das aves foram posteriormente identificadas em laboratório, através de comparações. Com a reprodução dos cantos e chamadas, algumas espécies foram atraídas e puderam ser identificadas visualmente.

Vielliard \& Silva (1989), testando a metodologia da identificação auditiva em fragmento de floresta tropical, determinaram que $90 \%$ dos contatos eram auditivos, comprovando a importância do reconhecimento da vocalização na identificação das aves.

O naturalista francês Eugène Ménétriès, que esteve no Brasil de 1822 a 1825, orientava-se pela vocalização das aves para determinar as espécies mais furtivas (Burmeister, 1980).

Algumas espécies, como os inhambus (Crypturellus spp), macuco (Tinamus solitarius) e jaó (Crypturellus undulatus), representantes da família Tinamidae, possuem vocalização bastante conhecida, importante para a sua identificação e registro, já que a visualização destas aves nos seus ambientes naturais é bastante difícil.

As observações foram realizadas em 6 períodos de amostragens, nas 4 estações do ano (verão, outono, inverno e primavera), ao longo do ano de 1997 , totalizando 80 horas efetivas de observações, distribuídas em 240 amostras (Tabela 04).

Tabela 04. Total de horas de observações para cada área estudada $(\mathrm{FV}=$ fragmento vermelho, $\mathrm{C}=$ corredor, $\mathrm{FA}=$ fragmento amarelo, $\mathrm{SB}=$ sub-bosque de eucalipto). 


\begin{tabular}{cccc}
\hline área & no dias & $\begin{array}{c}\text { no } \\
\text { amostras }\end{array}$ & no horas \\
\hline FV & 10 & 65 & 21,67 \\
C & 12 & 65 & 21,67 \\
FA & 12 & 70 & 23,33 \\
SB & 7 & 40 & 13,33 \\
total & 17 & 240 & 80 \\
\hline
\end{tabular}

Não foi possível realizar o mesmo número de amostras para cada área e estação do ano, em função das condições climáticas adversas, como chuva e vento forte, disponibilidade da equipe de apoio e problemas diversos.

\subsubsection{Método de captura e recaptura}

Para o levantamento através da captura e recaptura de aves foram utilizadas 36 redes neblina do tipo ATX, malha de nylon $36 \mathrm{~mm}$, cor preta. Estas redes medem $12 \mathrm{~m}$ de comprimento por 2,8 $\mathrm{m}$ de altura, formando 4 bolsas (Figura 11).

Para a distribuição das redes, foram inicialmente abertas trilhas no interior do fragmento vermelho (trilha dosper), fragmento amarelo (trilha doce infância), corredor (trilha do corredor) e sub-bosque de eucalipto (trilha do eucalipto). Foram instaladas 10 redes em cada fragmento, 10 redes no corredor e 6 redes no sub-bosque de eucalipto. Cada rede foi fixada por 2 bambus de $4 \mathrm{~m}$ de altura (1 em cada extremidade), para suportá-la e permitir o seu manuseio.

A instalação das redes foi realizada 1 dia antes do início de cada campanha, permanecendo no local até a conclusão da coleta daquela fase. As redes foram dispostas seqüencialmente ao longo das trilhas, mantendo-se uma distância mínima de 1 m entre uma e outra, não havendo sobreposição.

A abertura das redes iniciou-se por volta de 06:30 horas, permanecendo abertas até às 12:00 horas. Eventualmente foram abertas no período da tarde (das 16:00 às 18:00 horas). As mesmas foram mantidas a $10 \mathrm{~cm}$ do solo e, quando fechadas, permaneciam enroladas no próprio local de instalação.

Para efeito de cálculo do número de horas rede (HR), considerou-se para cada área, o intervalo de tempo entre a abertura e o fechamento da última rede. 
O trabalho de vistoria das redes era feito em intervalos de 20 a 30 minutos, dependendo do local e atividade das aves. O trabalho de retirada das aves capturadas foi auxiliado por uma equipe de estagiários da ESALQ - Escola Superior de Agricultura "Luiz de Queiroz", da Universidade de São Paulo, UNESP - Universidade Estadual Paulista (Campus de Rio Claro), PUC - Pontifícia Universidade Católica de Campinas e UFV - Universidade Federal de Viçosa. A ave retirada era mantida em saco de algodão e levada ao local de anilhamento, onde era identificada através de guias de campo ilustrados e descritivos.

Após a sua identificação, procedia-se o anilhamento com anilha de alumínio cedida pelo CEMAVE - Centro de Estudos e Migrações de Aves, do IBAMA Instituto Brasileiro do Meio Ambiente e Recursos Naturais Renováveis, que coordena todas as atividades de anilhamento de aves no Brasil. As anilhas do CEMAVE são fornecidas em vários tamanhos, sendo que cada tamanho corresponde a uma letra. Foram utilizadas neste trabalho, anilhas de tamanhos C, D, E, G, H, J, L e M. Além da letra, cada anilha possui uma numeração de 5 dígitos e a inscrição: Avise CEMAVE - CP 34 Brasília.

O anilhamento com anilhas do CEMAVE só foi utilizado quando havia total segurança da identificação da ave. Se houvesse dúvida, o anilhamento era feito com anilhas de alumínio com 3 números, fabricadas manualmente. A correta identificação era feita posteriormente, através de consultas aos materiais de museus. Para tanto, era feita uma descrição detalhada da ave, tomadas algumas medidas e fotografada.

A anilha colocada ao redor do tarso-metatarso da ave, deve movimentarse livremente para cima e para baixo sem causar atrito abrasivo, seja o tarso de formato circular ou elíptico. Como as anilhas são de metal, utilizaram-se alicates de ponta fina para a sua abertura e fechamento, tomando-se o cuidado para que as extremidades ficassem perfeitamente justapostas (Figura 12).

As aves das famílias Trochilidae (beija-flores) e Alcedinidae (martinspescadores) não foram anilhadas, devido aos pequenos tamanhos dos tarsos destas. Para os indivíduos capturados destas duas famílias, houve a marcação de penas, procedendo- 
se com um pequeno corte de aproximadamente $5 \mathrm{~mm}$ da extremidade das retrizes. Foram feitas combinações entre as retrizes das asas esquerda e direita, diferenciando desta forma, cada indivíduo capturado.

A marcação das aves é importante, pois nos proporciona informações sobre a razão dos sexos, movimentação dos indivíduos, crescimento, idade, longevidade e dinâmica das populações (Cottam, 1956).

Após o anilhamento ou marcação da pena, era feito um registro da ave capturada, anotando-se os seguintes dados em fichas de campo: nome da espécie, idade, sexo, número da rede e da bolsa onde houve a captura, data, local, horário e número da anilha (Anexo 01).

Para elaboração de acervo e para auxiliar no trabalho de identificação, foram fotografados 2 indivíduos (fêmea e macho) por espécie capturada.

Todas as aves foram soltas próximas do local da captura. Os indivíduos capturados mais de uma vez foram considerados recapturados.

A marcação das aves proporcionou informações quanto a movimentação dos indivíduos de diferentes espécies entre os fragmentos e ao longo do corredor.

Os trabalhos de captura e recaptura foram realizados em 5 períodos de amostragens, nas 4 estações do ano (verão, outono, inverno e primavera), ao longo do ano de 1997, totalizando 2.502 horas rede, de acordo com a Tabela 05.

Tabela 05. Total de dias e horas de levantamento por captura e recaptura $(\mathrm{FV}=$ fragmento vermelho, $\mathrm{C}=$ corredor, $\mathrm{FA}=$ fragmento amarelo, $\mathrm{SB}=$ subbosque de eucalipto).

\begin{tabular}{ccc}
\hline área & no dias & horas rede \\
\hline FV & 15 & 800 \\
C & 13 & 644 \\
FA & 17 & 824,5 \\
SB & 9 & 233,5 \\
total & 17 & 2.502 \\
\hline
\end{tabular}


Não foi possível realizar o mesmo número de horas rede para cada área e estação do ano, em função de condições climáticas adversas, como chuva e vento forte, tempo disponível da equipe de apoio e problemas diversos. 


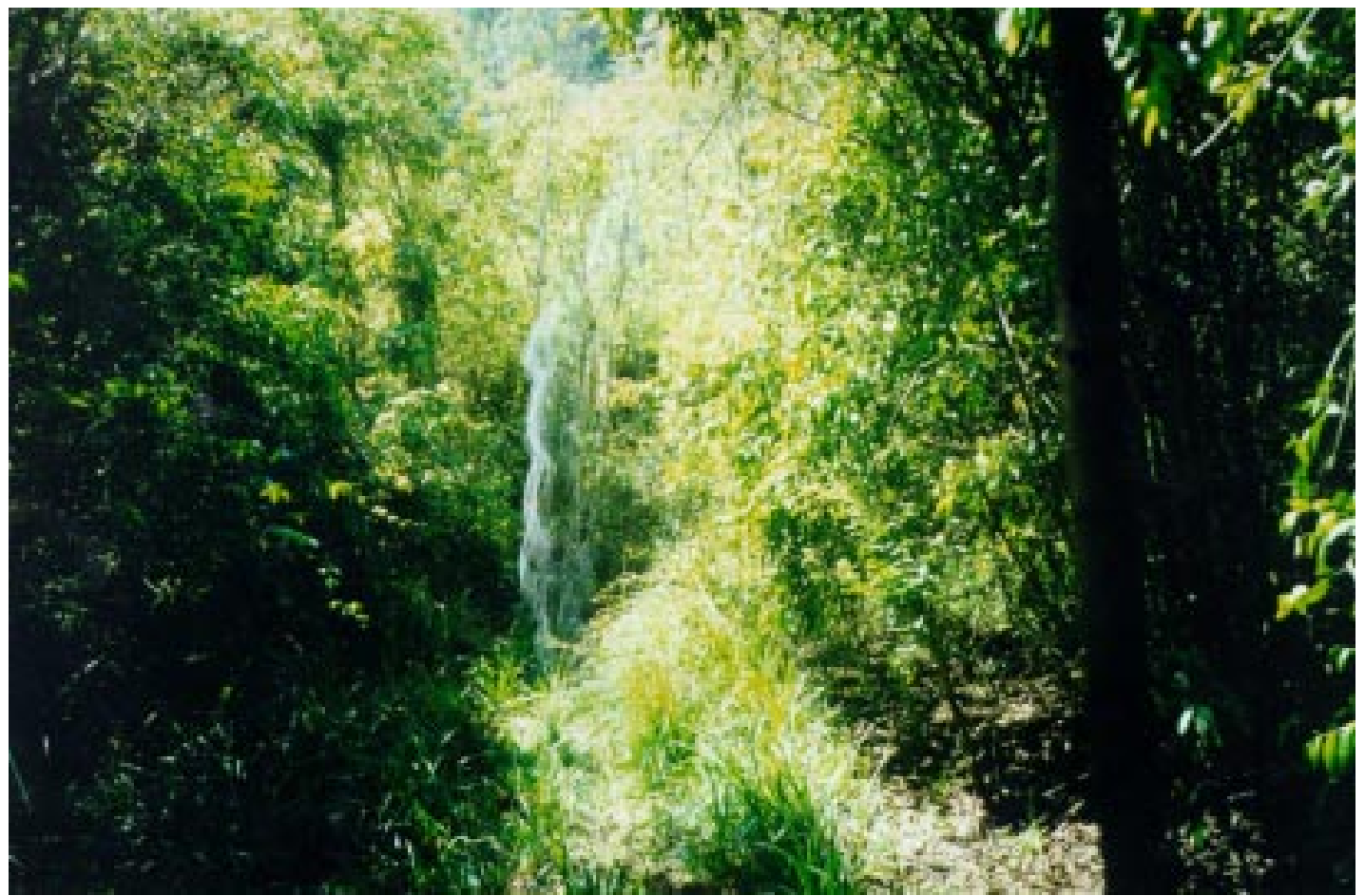

Figura 11. Detalhe da rede neblina instalada no interior do fragmento amarelo (observar que onde há boa penetração de luz há ocorrência de plantas invasoras).

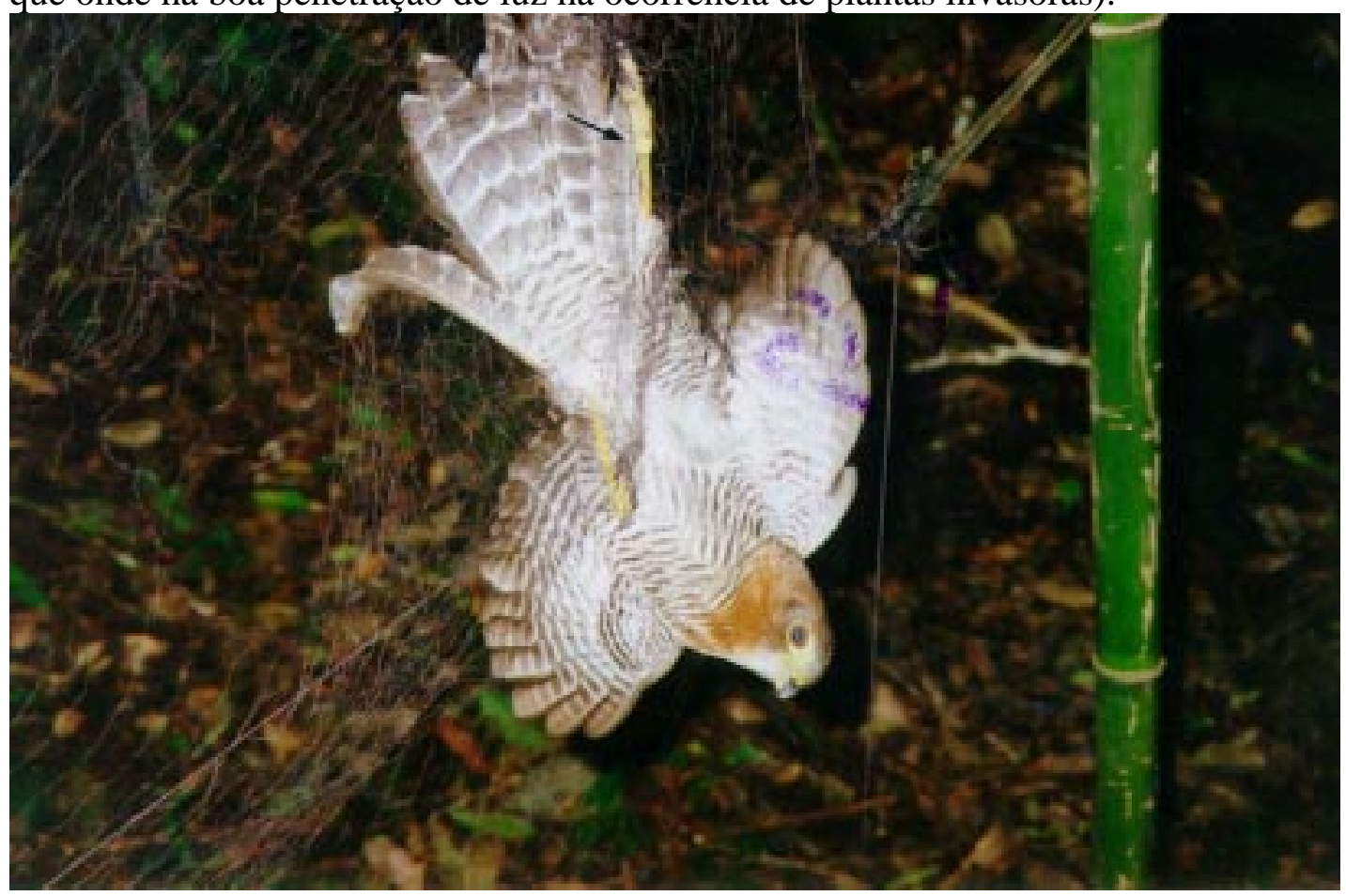

Figura 12. Micrastur ruficollis (gavião caburé), representante da guilda inseto-carnívora, capturado na rede neblina. Observar a anilha no tarso direito (por medida de segurança, procedeu-se o anilhamento antes da sua retirada da rede). 


\subsubsection{Análise da avifauna}

A amostragem por ponto fixo resultou em um levantamento quantitativo da avifauna das áreas estudadas, possibilitando obter os seguintes índices para cada espécie registrada:

\subsubsection{1 Índice pontual de abundância (IPA)}

O índice pontual de abundância indica a abundância de cada espécie em função do seu coeficiente de conspicuidade, através do número de contatos de determinada espécie e o número total de amostras.

$$
\mathrm{IPA}=\frac{\mathrm{Nci}}{\mathrm{Nta}}
$$

onde: IPA = índice pontual de abundância

$$
\begin{aligned}
& \text { Nci }=\text { número de contatos da espécie } \mathbf{i} \\
& \text { Nta }=\text { número total de amostras }
\end{aligned}
$$

O índice pontual de abundância permite obter uma densidade estimada, sendo que para as espécies mais populosas pode ocorrer uma superestimativa e para as menos populosas uma subestimativa. No entanto, este fato é inerente a todos os métodos de análise, e este índice é o que mais se aproxima da realidade por possibilitar a detecção das espécies raras (Vielliard \& Silva, 1989). 


\subsubsection{Freqüência de ocorrência (FO)}

A freqüência de ocorrência corresponde ao número de amostras em que determinada espécie foi observada em relação ao número total de amostras (Linsdale, 1928).

$$
\mathrm{FO}=\frac{\mathrm{Nai}}{\mathrm{Nta}} \times 100
$$

onde: $\quad F O=$ frequiência de ocorrência

Nai = número de amostras em que a espécie $\mathbf{i}$ foi observada

$\mathrm{Nta}=$ número total de amostras

\subsubsection{3 Índice de Kendeigh (IK)}

O índice de Kendeigh expressa a abundância de cada espécie na sua área de ocorrência, permitindo comparar a abundância relativa entre espécies diferentes ou dentro da mesma população.

$$
\mathrm{IK}=\sqrt{\mathrm{FOxNi}}
$$

onde: $\mathrm{IK}=$ índice de Kendeigh

$\mathrm{FO}=$ freqüência de ocorrência

$\mathrm{Ni}=$ número médio de indivíduos da espécie i (ni/Nai)

ni = número de indivíduos da espécie $\mathbf{i}$

Nai = número de amostras em que a espécie $\mathbf{i}$ foi observada 


\subsubsection{4 Índice de diversidade de Shannon-Weaver (H')}

O índice de diversidade de Shannon-Weaver permite que o grau de heterogeneidade das áreas seja conhecido, baseando-se no abundância proporcional de todas as espécies da comunidade (Shugart et al., 1978). Este índice é importante não só para o número de espécies da área mas também para a densidade populacional da área.

$$
H^{\prime}=-\sum \operatorname{pix} \ln (\mathrm{pi})
$$

onde: $\mathrm{H}^{\prime}$ = índice de diversidade de Shannon-Weaver

$$
\begin{aligned}
\text { pi = } & \text { número de indivíduos da espécie } \mathbf{i} \text { em relação ao número total } \\
& \text { de indivíduos da comunidade } \\
\ln = & \text { logaritmo neperiano }
\end{aligned}
$$

\subsubsection{5 Índice de eqüidade (E)}

Para determinar o índice de diversidade de Shannon-Weaver é necessário conhecer o número de indivíduos registrados em cada área. Para comparar o índice de diversidade de Shannon-Weaver de cada área é importante obter o índice de eqüidade, que representa a relação entre a diversidade observada e a diversidade máxima possível para o mesmo número de espécies, demonstrando o quanto de riqueza uma área pode abrigar, em função da abundância de espécies (Tramer, 1969).

$$
\mathrm{E}=\frac{\mathrm{H}^{\prime}}{\text { Hmáx }}
$$

onde: $\mathrm{E}=$ índice de eqüidade

H' = índice de diversidade de Shannon-Weaver

Hmáx = diversidade máxima suportada pela área $=\ln \mathrm{S}$

$\mathrm{S}$ = número de espécies da área

$\ln =$ logaritmo neperiano 


\subsubsection{6 Índice de similaridade de Jaccard (J)}

O índice de similaridade indica o grau de semelhança entre duas comunidades. Foi calculado o índice de similaridade de Jaccard para cada uma das combinações possíveis envolvendo os 4 ambientes de estudo.

$$
J=\frac{c}{a+b+c} \times 100
$$

onde: $\mathrm{a}=$ número de espécies exclusivas da comunidade 1

$\mathrm{b}=$ número de espécies exclusivas da comunidade 2

$\mathrm{c}=$ número de espécies em comum nas comunidades 1 e 2

O objetivo da amostragem por captura e recaptura não foi o de determinar o tamanho das populações das espécies de aves existentes, mas a freqüência de captura e recaptura, possibilitando obter os seguintes índices para cada espécie registrada:

\subsubsection{Freqüência de captura (FC)}

A freqüência de captura representa a relação entre o número de indivíduos capturados de uma população, pelo número de horas rede.

$$
\mathrm{FC}=\frac{\mathrm{Ci}}{\mathrm{HR}} \times 100
$$

onde: $\mathrm{FC}=$ freqüência de captura

$\mathrm{Ci}=$ número de capturas da espécie $\mathbf{i}$

$\mathrm{HR}=$ número de horas rede 


\subsubsection{Frequiência de recaptura $(F R)$}

A freqüência de recaptura representa a relação entre o número de indivíduos recapturados de uma população, pelo número de horas rede.

$$
\mathrm{FR}=\frac{\mathrm{Ri}}{\mathrm{HR}} \times 100
$$

onde: $\quad F R=$ freqüência de recaptura

$\mathrm{Ri}=$ número de recapturas da espécie $\mathbf{i}$

$\mathrm{HR}=$ número de horas rede

\subsubsection{Guildas alimentares}

A partir dos resultados obtidos nos levantamentos qualitativos e quantitativos, as aves foram agrupadas de acordo com a guilda alimentar, através das informações obtidas em campo, havendo a confirmação do hábito alimentar em publicação de Sick (1997).

Foram consideradas 8 guildas alimentares: frugívora, granívora, insetívora, inseto-carnívora, necrófaga, néctar-insetívora, onívora e piscívora.

- Frugívora: espécie que se alimenta basicamente de frutos;

- Granívora: espécie que se alimenta basicamente de sementes;

- Insetívora: espécie que se alimenta basicamente de insetos;

- Inseto-carnívora: espécie que se alimenta de insetos e pequenos vertebrados;

- Necrófaga: espécie que se alimenta de animais em decomposição;

- Néctar-insetívora: espécie que se alimenta de néctar e pequenos insetos;

- Onívora: espécie que se alimenta de frutos e complementa a alimentação com insetos, capins, brotos e sementes;

- Piscívora: espécie que se alimenta basicamente de peixes. 


\subsubsection{Distribuição da avifauna na estrutura vertical}

A ocupação vertical da floresta foi representada pela distribuição da avifauna de acordo com o nível predominante de cada espécie, baseado nos levantamentos de campo. Para tanto, foram considerados 4 níveis: aéreo, dossel, subbosque e solo.

- Aéreo: observada sobrevoando a floresta;

- Dossel: observada no estrato superior da floresta;

- Sub-bosque: observada no sub-bosque e no estrato médio da floresta;

- Solo: observada no estrato herbáceo e no piso da floresta. 


\section{RESULTADOS E DISCUSSÃO}

\subsection{Avifauna}

\subsubsection{Composição geral da avifauna}

Considerando-se todas as áreas estudadas e os métodos de levantamentos utilizados, foram registradas 135 espécies de aves, distribuídas em 33 famílias e 14 ordens, apresentadas nas Tabelas 06 e 07.

Höfling \& Lencioni (1992), estudando a avifauna ao longo de uma trilha na Serra do Mar, entre os municípios de Salesópolis e Caraguatatuba, Estado de São Paulo, com altitude variando de 1.200 a 550 m, registraram em 144 horas de observação, 188 espécies de aves distribuídas em 31 famílias.

Toledo (1993), estudando a avifauna de 2 reservas da Mata Atlântica localizadas na Serra da Mantiqueira, no Município de Pindamonhangaba, região do Vale do Paraíba, Estado de São Paulo, registrou 102 espécies de aves distribuídas em 30 famílias.

Allegrini (1997), estudando a avifauna em diferentes estágios de regeneração da Mata Atlântica, nas encostas da Serra de Paranapiacaba, no Município de Iporanga, sul do Estado de São Paulo, registrou 217 espécies de aves distribuídas em 40 famílias. O número de espécies registradas em cada estágio de regeneração foi: 67 no pioneiro, 97 no inicial, 99 no médio e 79 no avançado.

Dentre as espécies registradas na área de estudo, 6 são consideradas endêmicas da Mata Atlântica e 1 ameaçada de extinção (Sick, 1997), demonstrando a importância da preservação destes ambientes naturais. 
- Espécies endêmicas:

Phaetornis squalidus e Clytolaema rubricauda, espécies umbrófilas da família Trochilidae, habitam o sub-bosque da Mata Atlântica do sudeste do Brasil, e foram registradas apenas no levantamento qualitativo;

Drymophila squamata, espécie umbrófila da família Thamnophilidae, habita o sub-bosque da Mata Attântica, entre a Bahia e Santa Catarina, e foi registrada 16 vezes (4 no fragmento vermelho, 9 no corredor e 3 no fragmento amarelo);

Phacellodomus (erythrophthalmus) ferrugineigula, espécie da família Furnariidae e subfamília Synallaxinae, vive em área de brejo da Mata Attântica, entre Minas Gerais e o Rio Grande do Sul, possui hábitat, ninho e vocalização diferentes da espécie Phacellodomus erythrophthalmus, constituindo-se numa raça geográfica, podendo ser elevada a condição de espécie (Sick, 1997), foi registrada 20 vezes (3 no fragmento vermelho, 8 no corredor, 7 no fragmento amarelo e 2 no sub-bosque de eucalipto);

Hemithraupis ruficapilla, espécie silvestre da família Emberizidae e subfamília Thraupinae, é restrita ao litoral do sudeste do Brasil, vivendo nos topos das árvores da Mata Atlântica, foi observada 11 vezes (4 no fragmento vermelho, 4 no corredor e 3 no fragmento amarelo);

Tangara desmaresti, espécie da família Emberizidae e subfamília Thraupinae, habita as capoeiras da Mata Atlântica, do Espírito Santo à Santa Catarina, geralmente associada à grupos mistos, foi observada 62 vezes (12 no fragmento vermelho, 46 no corredor e 4 no fragmento amarelo).

- Espécie ameaçada de extinção:

Phylloscartes paulistus, espécie florestal pouco conhecida, da família Tyrannidae e subfamília Elaeniinae, tratada como espécie vulnerável ou rara por Collar et al. (1992), ocorre na Mata Atlântica, do Espírito Santo ao nordeste de Santa Catarina, foi observada 9 vezes ( 1 no fragmento vermelho, 2 no corredor e 6 no fragmento amarelo).

Pode-se reunir estas 33 famílias nos 5 grupos das aves que vivem na região neotrópica, que se estende do sul do México ( $20^{\circ}$ de Latitude Norte) até o Cabo 
de Hornos ( $57^{\circ}$ de Latitude Sul), incluindo a parte meridional não trópica da América do Sul (Haffer, 1974). Esta região ainda compreende a faixa que vai das Ilhas Galápagos às Ilhas Tristão da Cunha (Rand, 1955).

- Famílias neotropicais:

Tinamidae, Cathartidae, Cariamidae, Nyctibiidae, Ramphastidae, Dendrocolaptidae, Thamnophilidae, Conopophagidae, Furnariidae e Pipridae

- Famílias de distribuição mais ou menos extensa na América do Sul e do Norte:

Cracidae, Trochilidae, Tyrannidae, Troglodytidae, Vireonidae e Emberizidae

- Família de distribuição pantropical:

Psittacidae

- Famílias oriundas do Velho Mundo:

Columbidae, Cuculidae, Corvidae e Muscicapidae

- Famílias largamente distribuídas no mundo inteiro:

Ardeidae, Accipitridae, Falconidae, Rallidae, Tytonidae, Strigidae, Caprimulgidae, Apodidae, Alcedinidae, Picidae, Hirundinidae e Fringillidae

As famílias com maior número de espécies são Tyrannidae (30) e Emberizidae (23). Na atual classificação sistemática (Sick, 1997), a família Emberizidae engloba a maioria dos pássaros pertencentes à família Fringillidae, que foram agrupados nas subfamílias Emberizinae e Cardialinae, as famílias Parulidae, Coerebidae e Thraupidae, transformadas respectivamente em subfamílias Parulinae, Coerebinae e Thraupinae.

Os indivíduos das espécies Picumnus cirratus cirratus e Picumnus cirratus temmincki observados no levantamento foram registrados como Picumnus cirratus, pelas dificuldades encontradas na identificação separada dos mesmos. 
Tabela 06. Relação das ordens, subordens, famílias e subfamílias registradas na área de estudo (entre parêntesis, o número de espécies registradas).

\begin{tabular}{|c|c|c|c|}
\hline ordem & subordem & família & subfamília \\
\hline Tinamiformes (1) & & Tinamidae (1) & Tinaminae (1) \\
\hline \multirow[t]{2}{*}{ Ciconiiformes (4) } & & Ardeidae (2) & \\
\hline & & Cathartidae (2) & \\
\hline \multirow[t]{2}{*}{ Falconiformes (7) } & & Accipitridae (3) & \\
\hline & & Falconidae (4) & \\
\hline Galliformes (1) & & Cracidae (1) & \\
\hline \multirow[t]{2}{*}{ Gruiformes (3) } & & Rallidae (2) & \\
\hline & & Cariamidae (1) & \\
\hline Columbiformes (4) & & Columbidae (4) & \\
\hline Psittaciformes (1) & & Psittacidae (1) & \\
\hline Cuculiformes (3) & & Cuculidae (3) & \\
\hline \multirow[t]{2}{*}{ Strigiformes (3) } & & Tytonidae (1) & \\
\hline & & Strigidae (2) & \\
\hline \multirow[t]{2}{*}{ Caprimulgiformes (3) } & & Nyctibiidae (1) & \\
\hline & & Caprimulgidae (2) & \\
\hline \multirow[t]{2}{*}{ Apodiformes (13) } & & Apodidae (1) & \\
\hline & & Trochilidae (12) & \\
\hline Coraciiformes (1) & & Alcedinidae (1) & \\
\hline \multirow[t]{2}{*}{ Piciformes (6) } & & Ramphastidae (1) & \\
\hline & & Picidae (5) & \\
\hline \multirow[t]{21}{*}{ Passeriformes (85) } & \multirow[t]{10}{*}{ Suboscines (49) } & Thamnophilidae (7) & \\
\hline & & Conopophagidae (1) & \\
\hline & & Furnariidae (7) & Synallaxinae (5) \\
\hline & & & Philydorinae (2) \\
\hline & & Dendrocolaptidae (2) & \\
\hline & & Tyrannidae (30) & Elaeniinae (17) \\
\hline & & & Fluvicolinae (5) \\
\hline & & & Tyranninae (7) \\
\hline & & & Tityrinae (1) \\
\hline & & Pipridae (2) & \\
\hline & \multirow[t]{11}{*}{ Oscines (36) } & Hirundinidae (2) & \\
\hline & & Corvidae (1) & \\
\hline & & Troglodytidae (1) & \\
\hline & & Muscicapidae (4) & Turdinae (4) \\
\hline & & Vireonidae (4) & \\
\hline & & Emberizidae (23) & Parulinae (4) \\
\hline & & & Coerebinae (1) \\
\hline & & & Thraupinae (12) \\
\hline & & & Emberizinae (5) \\
\hline & & & Cardinalinae (1) \\
\hline & & Fringillidae (1) & Carduelinae (1) \\
\hline
\end{tabular}


Tabela 07. Relação das famílias, subfamílias e espécies registradas na área de estudo.

\begin{tabular}{|c|c|c|}
\hline família & subfamília & espécie \\
\hline Tinamidae & Tinaminae & Crypturellus obsoletus (Temminck, 1815) \\
\hline Ardeidae & & $\begin{array}{l}\text { Butorides striatus (Linnaeus, 1758) } \\
\text { Tigrisoma lineatum (Boddaert, 1783) }\end{array}$ \\
\hline Cathartidae & & $\begin{array}{l}\text { Cathartes aura (Linnaeus, 1758) } \\
\text { Coragyps atratus (Bechstein, 1793) }\end{array}$ \\
\hline Accipitridae & & $\begin{array}{l}\text { Buteo albicaudatus (Vieillot, 1816) } \\
\text { Buteo brachyurus (Vieillot, 1816) } \\
\text { Rupornis magnirostris (Gmelin, 1788) }\end{array}$ \\
\hline Falconidae & & $\begin{array}{l}\text { Herpetotheres cachinnans (Linnaeus, 1758) } \\
\text { Micrastur ruficollis (Vieillot, 1817) } \\
\text { Milvago chimachima (Vieillot, 1816) } \\
\text { Polyborus plancus (Miller, 1777) }\end{array}$ \\
\hline Cracidae & & Penelope superciliaris (Temminck, 1815) \\
\hline Rallidae & & $\begin{array}{l}\text { Rallus nigricans (Vieillot, 1819) } \\
\text { Porzana albicollis (Vieillot, 1819) }\end{array}$ \\
\hline Cariamidae & & Cariama cristata (Linnaeus, 1766) \\
\hline Columbidae & & $\begin{array}{l}\text { Columba picazuro }(\text { Temminck, } 1813) \\
\text { Columbina talpacoti }(\text { Temminck, } 1811) \\
\text { Leptotila verreauxi (Bonaparte, } 1855) \\
\text { Geotrygon montana (Linnaeus, } 1758)\end{array}$ \\
\hline Psittacidae & & Pionus maximiliani (Kuhl, 1820) \\
\hline Cuculidae & & $\begin{array}{l}\text { Piaya cayana (Linnaeus, 1766) } \\
\text { Guira guira (Gmelin, 1788) } \\
\text { Tapera naevia (Linnaeus, 1766) }\end{array}$ \\
\hline Tytonidae & & Tyto alba (Scopoli, 1769) \\
\hline Strigidae & & $\begin{array}{l}\text { Otus choliba (Vieillot, 1817) } \\
\text { Speotyto cunicularia (Molina, 1782) }\end{array}$ \\
\hline Nyctibiidae & & Nyctibius griseus (Gmelin, 1789) \\
\hline Caprimulgidae & & $\begin{array}{l}\text { Nyctidromus albicollis (Gmelin, 1789) } \\
\text { Hydropsalis brasiliana (Gmelin, 1789) }\end{array}$ \\
\hline Apodidae & & Streptoprocne zonaris (Shaw, 1796) \\
\hline Trochilidae & & $\begin{array}{l}\text { Phaethornis eurynome (Lesson, 1832) } \\
\text { Phaethornis squalidus (Temminck, 1822) } \\
\text { Phaethornis pretrei (Lesson \& De Lattre, 1839) } \\
\text { Melanotrochilus fuscus (Vieillot, 1817) } \\
\text { Stephanoxis lalandi (Vieillot, 1818) } \\
\text { Chlorostilbon aureoventris } \\
\text { (d'Orbigny \& Lafresnaye, 1838) } \\
\text { Thalurania glaucopis (Gmelin, 1788) } \\
\text { Leucochloris albicollis (Vieillot, 1818) } \\
\text { Amazilia versicolor (Vieillot, 1818) } \\
\text { Amazilia fimbriata (Gmelin, 1788) } \\
\text { Aphantochroa cirrhochloris (Vieillot, 1818) } \\
\text { Clytolaema rubricauda (Boddaert, 1783) }\end{array}$ \\
\hline
\end{tabular}


Tabela 07. Relação das famílias, subfamílias e espécies registradas na área de estudo.

\begin{tabular}{|c|c|c|}
\hline família & subfamília & espécie \\
\hline Alcedinidae & & Chloroceryle americana (Gmelin, 1788) \\
\hline Ramphastidae & & Pteroglossus castanotis (Gould, 1833) \\
\hline \multirow[t]{5}{*}{ Picidae } & & Picumnus cirratus (Temminck, 1825) \\
\hline & & Colaptes campestris (Vieillot, 1818) \\
\hline & & Colaptes melanochloros (Gmelin, 1788) \\
\hline & & Veniliornis spilogaster (Wagler, 1827) \\
\hline & & Veniliornis passerinus (Linnaeus, 1766) \\
\hline \multirow[t]{7}{*}{ Thamnophilidae } & & Mackenziaena severa (Lichtenstein, 1823) \\
\hline & & Thamnophilus doliatus (Linnaeus, 1764) \\
\hline & & Thamnophilus caerulescens (Vieillot, 1816) \\
\hline & & Dysithamnus mentalis (Temminck, 1823) \\
\hline & & Drymophila malura (Temminck, 1825) \\
\hline & & Drymophila squamata (Temminck, 1823) \\
\hline & & Pyriglena leucoptera (Vieillot, 1818) \\
\hline Conopophagidae & & Conopophaga lineata $(\mathrm{Wied}, 1831)$ \\
\hline \multirow[t]{7}{*}{ Furnariidae } & Synallaxinae & Synallaxis spixi (Sclater, 1856) \\
\hline & & Synallaxis ruficapilla (Vieillot, 1819) \\
\hline & & Synallaxis cinerascens (Temminck, 1823) \\
\hline & & Phacellodomus rufifrons (Wied, 1821) \\
\hline & & $\begin{array}{l}\text { Phacellodomus (erythrophthalmus) ferrugineigula } \\
\text { (Wied, 1821) }\end{array}$ \\
\hline & Philydorinae & Syndactyla rufosuperciliata (Lafresnaye, 1832) \\
\hline & & Lochmias nematura (Lichtenstein, 1823) \\
\hline \multirow[t]{2}{*}{ Dendrocolaptidae } & & Sittasomus griseicapillus (Vieillot, 1818) \\
\hline & & Lepidocolaptes fuscus (Vieillot, 1818) \\
\hline \multirow[t]{17}{*}{ Tyrannidae } & Elaeniinae & Camptostoma obsoletum (Temminck, 1824) \\
\hline & & Elaenia flavogaster (Thunberg, 1822) \\
\hline & & Elaenia parvirostris (Pelzeln, 1868) \\
\hline & & Elaenia cristata (Pelzeln, 1868) \\
\hline & & Elaenia obscura (d'Orbigny \& Lafresnaye, 1837) \\
\hline & & Serpophaga subcristata (Vieillot, 1817) \\
\hline & & Mionectes rufiventris (Cabanis, 1846) \\
\hline & & Leptopogon amaurocephalus (Tschudi, 1846) \\
\hline & & Phylloscartes paulistus (Ihering \& Ihering, 1907) \\
\hline & & Capsiempis flaveola (Lichtenstein, 1823) \\
\hline & & Myiornis auricularis (Vieillot, 1818) \\
\hline & & Todirostrum poliocephalum (Wied, 1831) \\
\hline & & Todirostrum cinereum (Linnaeus, 1766) \\
\hline & & Todirostrum plumbeiceps (Lafresnaye, 1846) \\
\hline & & Tolmomyias sulphurescens (Spix, 1825) \\
\hline & & Tolmomyias poliocephalus (Hellmayr, 1903) \\
\hline & & Platyrinchus mystaceus (Vieillot, 1818) \\
\hline
\end{tabular}


Tabela 07. Relação das famílias, subfamílias e espécies registradas na área de estudo.

\begin{tabular}{|c|c|c|}
\hline família & subfamília & espécie \\
\hline \multirow[t]{13}{*}{ Tyrannidae } & Fluvicolinae & Myiobius barbatus (Gmelin, 1789) \\
\hline & & Myiophobus fasciatus (Müller, 1776) \\
\hline & & Lathrotriccus euleri (Cabanis, 1868) \\
\hline & & Knipolegus lophotes (Boie, 1828) \\
\hline & & Knipolegus cyanirostris (Vieillot, 1818) \\
\hline & Tyranninae & Attila rufus (Vieillot, 1819) \\
\hline & & Myiarchus ferox (Gmelin, 1789) \\
\hline & & Pitangus sulphuratus (Linnaeus, 1760) \\
\hline & & Myiozetetes similis (Spix, 1825) \\
\hline & & Empidonomus varius (Vieillot, 1818) \\
\hline & & Tyrannus savana (Linnaeus, 1766) \\
\hline & & Tyrannus melancholicus (Vieillot, 1819) \\
\hline & Tityrinae & Pachyramphus polychopterus (Vieillot, 1818) \\
\hline Pipridae & & $\begin{array}{l}\text { Chiroxiphia caudata (Shaw \& Nodder, 1793) } \\
\text { Ilicura militaris (Shaw \& Nodder, 1808) }\end{array}$ \\
\hline \multirow[t]{2}{*}{ Hirundinidae } & & Notiochelidon cyanoleuca (Vieillot, 1817) \\
\hline & & Stelgidopteryx ruficollis (Vieillot, 1817) \\
\hline Corvidae & & Cyanocorax cristatellus (Temminck, 1823) \\
\hline Troglodytidae & & Troglodytes aedon (Vieillot, 1808) \\
\hline \multirow[t]{4}{*}{ Muscicapidae } & Turdinae & Platycichla flavipes (Vieillot, 1818) \\
\hline & & Turdus rufiventris (Vieillot, 1818) \\
\hline & & Turdus amaurochalinus (Cabanis, 1851) \\
\hline & & Turdus albicollis (Vieillot, 1818) \\
\hline \multirow[t]{4}{*}{ Vireonidae } & & Cyclarhis gujanensis (Gmelin, 1789) \\
\hline & & Vireo olivaceus (Linnaeus, 1766) \\
\hline & & Hylophilus poicilotis (Temminck, 1822) \\
\hline & & Hylophilus thoracicus (Temminck, 1822) \\
\hline \multirow[t]{17}{*}{ Emberizidae } & Parulinae & Parula pitiayumi (Vieillot, 1817) \\
\hline & & Geothlypis aequinoctialis (Gmelin, 1789) \\
\hline & & Basileuterus culicivorus (Lichtenstein, 1830) \\
\hline & & Basileuterus leucoblepharus (Vieillot, 1817) \\
\hline & Coerebinae & Coereba flaveola (Linnaeus, 1758) \\
\hline & Thraupinae & Thlypopsis sordida (d'Orbigny \& Lafresnaye, 1837) \\
\hline & & Hemithraupis ruficapilla (Vieillot, 1818) \\
\hline & & Tachyphonus coronatus (Vieillot, 1822) \\
\hline & & Trichothraupis melanops (Vieillot, 1818) \\
\hline & & Thraupis sayaca (Linnaeus, 1766) \\
\hline & & Stephanophorus diadematus (Temminck, 1823) \\
\hline & & Pipraeidea melanonota (Vieillot, 1819) \\
\hline & & Euphonia chlorotica (Linnaeus, 1766) \\
\hline & & Tangara desmaresti (Vieillot, 1819) \\
\hline & & Tangara cayana (Linnaeus, 1766) \\
\hline & & Dacnis cayana (Linnaeus, 1766) \\
\hline & & Conirostrum speciosum (Temminck, 1824) \\
\hline
\end{tabular}


Tabela 07. Relação das famílias, subfamílias e espécies registradas na área de estudo.

\begin{tabular}{|c|c|c|}
\hline família & subfamília & espécie \\
\hline \multirow{6}{*}{ Emberizidae } & Emberizinae & Zonotrichia capensis (Müller, 1766) \\
\hline & & Haplospiza unicolor (Cabanis, 1851) \\
\hline & & Volatinia jacarina (Linnaeus, 1766) \\
\hline & & Sporophila caerulescens (Vieillot, 1823) \\
\hline & & Arremon flavirostris (Swainson, 1838) \\
\hline & Cardinalinae & Saltator similis (Lafresnaye \& d'Orbigny, 1837) \\
\hline Fringillidae & Carduelinae & Carduelis magellanicus (Vieillot, 1805) \\
\hline
\end{tabular}

\subsubsection{Estrutura e comunidade trófica das aves}

Na Tabela 08 estão relacionadas as espécies registradas na área, a guilda alimentar e o estrato predominante da vegetação em que foram observadas.

Tabela 08. Composição da avifauna por guilda e pela ocupação vertical da floresta.

\begin{tabular}{lcc}
\hline \multicolumn{1}{c}{ espécie } & guilda & estrato \\
\hline Crypturellus obsoletus & onívora & solo \\
Butorides striatus & piscívora & sub-bosque \\
Tigrisoma lineatum & necrófaga & sub-bosque \\
Cathartes aura & necrófaga & aéreo \\
Coragyps atratus & inseto-carnívora & dossel \\
Buteo albicaudatus & inseto-carnívora & dossel \\
Buteo brachyurus & inseto-carnívora & dossel \\
Rupornis magnirostris & inseto-carnívora & dossel \\
Herpetotheres cachinnans & inseto-carnívora & dossel \\
Micrastur ruficollis & inseto-carnívora & dossel \\
Milvago chimachima & inseto-carnívora & solo \\
Polyborus plancus & onívora & sub-bosque \\
Penelope superciliaris & onívora & solo \\
Rallus nigricans & onívora & solo \\
Porzana albicollis & inseto-carnívora & solo \\
Cariama cristata & granívora & solo \\
Columba picazuro & granívora & sub-bosque \\
Columbina talpacoti & granívora & sub-bosque \\
Leptotila verreauxi & granívora & sub-bosque \\
Geotrygon montana & granívora & aéreo \\
Pionus maximiliani & inseto-carnívora & sub-bosque \\
Piaya cayana & inseto-carnívora & sub-bosque \\
Guira guira & inseto-carnívora & sub-bosque \\
Tapera naevia & inseto-carnívora & sub-bosque \\
Tyto alba & & \\
\hline
\end{tabular}


Tabela 08. Composição da avifauna por guilda e pela ocupação vertical da floresta.

\begin{tabular}{|c|c|c|}
\hline espécie & guilda & estrato \\
\hline Otus choliba & inseto-carnívora & sub-bosque \\
\hline Speotyto cunicularia & inseto-carnívora & solo \\
\hline Nyctibius griseus & insetívora & sub-bosque \\
\hline Nyctidromus albicollis & insetívora & solo \\
\hline Hydropsalis brasiliana & insetívora & solo \\
\hline Streptoprocne zonaris & insetívora & aéreo \\
\hline Phaethornis eurynome & néctar-insetívora & sub-bosque \\
\hline Phaethornis squalidus & néctar-insetívora & sub-bosque \\
\hline Phaethornis pretrei & néctar-insetívora & sub-bosque \\
\hline Melanotrochilus fuscus & néctar-insetívora & sub-bosque \\
\hline Stephanoxis lalandi & néctar-insetívora & sub-bosque \\
\hline Chlorostilbon aureoventris & néctar-insetívora & sub-bosque \\
\hline Thalurania glaucopis & néctar-insetívora & sub-bosque \\
\hline Leucochloris albicollis & néctar-insetívora & sub-bosque \\
\hline Amazilia versicolor & néctar-insetívora & sub-bosque \\
\hline Amazilia fimbriata & néctar-insetívora & sub-bosque \\
\hline Aphantochroa cirrhochloris & néctar-insetívora & sub-bosque \\
\hline Clytolaema rubricauda & néctar-insetívora & sub-bosque \\
\hline Chloroceryle americana & piscívora & sub-bosque \\
\hline Pteroglossus castanotis & frugívora & dossel \\
\hline Picumnus cirratus & insetívora & sub-bosque \\
\hline Colaptes campestris & insetívora & solo \\
\hline Colaptes melanochloros & insetívora & dossel \\
\hline Veniliornis spilogaster & insetívora & dossel \\
\hline Veniliornis passerinus & insetívora & sub-bosque \\
\hline Mackenziaena severa & insetívora & sub-bosque \\
\hline Thamnophilus doliatus & insetívora & sub-bosque \\
\hline Thamnophilus caerulescens & insetívora & sub-bosque \\
\hline Dysithamnus mentalis & insetívora & sub-bosque \\
\hline Drymophila malura & insetívora & sub-bosque \\
\hline Drymophila squamata & insetívora & sub-bosque \\
\hline Pyriglena leucoptera & insetívora & sub-bosque \\
\hline Conopophaga lineata & insetívora & sub-bosque \\
\hline Synallaxis spixi & insetívora & sub-bosque \\
\hline Synallaxis ruficapilla & insetívora & sub-bosque \\
\hline Synallaxis cinerascens & insetívora & sub-bosque \\
\hline Phacellodomus rufifrons & insetívora & sub-bosque \\
\hline Phacellodomus ferrugineigula & insetívora & sub-bosque \\
\hline Syndactyla rufosuperciliata & insetívora & sub-bosque \\
\hline Lochmias nematura & insetívora & sub-bosque \\
\hline Sittasomus griseicapillus & insetívora & sub-bosque \\
\hline Lepidocolaptes fuscus & insetívora & sub-bosque \\
\hline Camptostoma obsoletum & insetívora & sub-bosque \\
\hline Elaenia flavogaster & insetívora & sub-bosque \\
\hline Elaenia parvirostris & insetívora & sub-bosque \\
\hline
\end{tabular}


Tabela 08. Composição da avifauna por guilda e pela ocupação vertical da floresta.

\begin{tabular}{|c|c|c|}
\hline espécie & guilda & estrato \\
\hline Elaenia cristata & insetívora & sub-bosque \\
\hline Elaenia obscura & insetívora & sub-bosque \\
\hline Serpophaga subcristata & insetívora & sub-bosque \\
\hline Mionectes rufiventris & insetívora & sub-bosque \\
\hline Leptopogon amaurocephalus & insetívora & sub-bosque \\
\hline Phylloscartes paulistus & insetívora & sub-bosque \\
\hline Capsiempis flaveola & insetívora & sub-bosque \\
\hline Myiornis auricularis & insetívora & sub-bosque \\
\hline Todirostrum poliocephalum & insetívora & sub-bosque \\
\hline Todirostrum cinereum & insetívora & sub-bosque \\
\hline Todirostrum plumbeiceps & insetívora & sub-bosque \\
\hline Tolmomyias sulphurescens & insetívora & sub-bosque \\
\hline Tolmomyias poliocephalus & insetívora & dossel \\
\hline Platyrinchus mystaceus & insetívora & sub-bosque \\
\hline Myiobius barbatus & insetívora & sub-bosque \\
\hline Myiophobus fasciatus & insetívora & sub-bosque \\
\hline Lathrotriccus euleri & insetívora & sub-bosque \\
\hline Knipolegus lophotes & insetívora & sub-bosque \\
\hline Knipolegus cyanirostris & insetívora & sub-bosque \\
\hline Attila rufus & insetívora & sub-bosque \\
\hline Myiarchus ferox & insetívora & sub-bosque \\
\hline Pitangus sulphuratus & insetívora & dossel \\
\hline Myiozetetes similis & insetívora & dossel \\
\hline Empidonomus varius & insetívora & dossel \\
\hline Tyrannus savana & insetívora & dossel \\
\hline Tyrannus melancholicus & insetívora & dossel \\
\hline Pachyramphus polychopterus & insetívora & dossel \\
\hline Chiroxiphia caudata & onívora & sub-bosque \\
\hline Ilicura militaris & onívora & sub-bosque \\
\hline Notiochelidon cyanoleuca & insetívora & aéreo \\
\hline Stelgidopteryx ruficollis & insetívora & aéreo \\
\hline Cyanocorax cristatellus & onívora & dossel \\
\hline Troglodytes aedon & insetívora & sub-bosque \\
\hline Platycichla flavipes & onívora & sub-bosque \\
\hline Turdus rufiventris & onívora & sub-bosque \\
\hline Turdus amaurochalinus & onívora & sub-bosque \\
\hline Turdus albicollis & onívora & sub-bosque \\
\hline Cyclarhis gujanensis & onívora & sub-bosque \\
\hline Vireo olivaceus & onívora & sub-bosque \\
\hline Hylophilus poicilotis & onívora & dossel \\
\hline Hylophilus thoracicus & onívora & sub-bosque \\
\hline Parula pitiayumi & insetívora & sub-bosque \\
\hline Geothlypis aequinoctialis & insetívora & sub-bosque \\
\hline Basileuterus culicivorus & insetívora & sub-bosque \\
\hline
\end{tabular}




\begin{tabular}{lll}
\hline Basileuterus leucoblepharus $\quad$ insetívora sub-bosque \\
\hline
\end{tabular}

Tabela 08. Composição da avifauna por guilda e pela ocupação vertical da floresta.

\begin{tabular}{lcc}
\hline \multicolumn{1}{c}{ espécie } & guilda & estrato \\
\hline Coereba flaveola & néctar-insetívora & sub-bosque \\
Thlypopsis sordida & onívora & dossel \\
Hemithraupis ruficapilla & onívora & dossel \\
Tachyphonus coronatus & onívora & sub-bosque \\
Trichothraupis melanops & onívora & sub-bosque \\
Thraupis sayaca & onívora & sub-bosque \\
Stephanophorus diadematus & onívora & sub-bosque \\
Pipraeidea melanonota & onívora & sub-bosque \\
Euphonia chlorotica & onívora & dossel \\
Tangara desmaresti & onívora & sub-bosque \\
Tangara cayana & onívora & dossel \\
Dacnis cayana & onívora & dossel \\
Conirostrum speciosum & onívora & sub-bosque \\
Zonotrichia capensis & granívora & sub-bosque \\
Haplospiza unicolor & granívora & sub-bosque \\
Volatinia jacarina & granívora & sub-bosque \\
Sporophila caerulescens & granívora & sub-bosque \\
Arremon flavirostris & granívora & sub-bosque \\
Saltator similis & granívora & sub-bosque \\
Carduelis magellanicus & granívora & sub-bosque \\
\hline
\end{tabular}

Entre as 135 espécies registradas na área de estudo foram caracterizadas 1 frugívora (0,74\%), 12 granívoras (8,89\%), 63 insetívoras (46,67\%), 14 inseto-carnívoras (10,37\%), 2 necrófagas (1,48\%), 13 néctar-insetívoras $(9,63 \%)$, e 27 onívoras $(20,00 \%)$ e 3 piscívoras $(2,22 \%)$.

Comparando-se os dados obtidos por Willis (1979), quanto aos nichos tróficos ocupados pelas espécies de aves da floresta de Barreiro Rico, no Município de Anhembi, Estado de São Paulo e de Almeida (1981), em fragmentos de matas ciliares na mesma região, observa-se que nas matas ciliares e capoeiras predominam as espécies insetívoras, onívoras e granívoras que vivem na borda da floresta.

Este fato é constatado na área de estudo, constituída de mata ciliar com vegetação em estágio médio de regeneração, onde $75,56 \%$ das espécies registradas pertencem à guilda insetívora, onívora ou granívora.

Almeida (1981) constatou que as maiores reduções quanto à fragmentação de hábitats ocorrem entre as espécies insetívoras, seguindo-se as onívoras 
de grande porte que se alimentam no chão e as onívoras que se alimentam de insetos e frutos grandes.

Dentre as espécies onívoras de grande porte que se alimentam no chão, houve o registro apenas do Crypturellus obsoletus, de grande valor cinegético e que habita matas densas. Outras importantes espécies deste grupo, mas que não foram registradas na área são o Crypturellus tataupa e Tinamus solitarius, registradas por Allegrini (1997) em ambientes com estágio médio e avançado de regeneração, na Serra de Paranapiacaba, sul do Estado de São Paulo. Segundo Terborgh \& Weske (1969), estas espécies estão entre os representantes mais ameaçados de extinção pela fragmentação de áreas florestais.

A guilda alimentar mais importante na área de estudo é a insetívora (Figura 13), seguida da onívora (Figura 14) e inseto-carnívora (Figura 12). Estas 3 guildas correspondem a 75,56\% das espécies observadas nos ambientes estudados. Outras guildas importantes são a néctar-insetívora, representada por 12 espécies de beija-flores ( $3^{\mathrm{a}}$ maior família em número de espécies) e a granívora.

Foram observadas predominantemente 6 espécies $(4,44 \%)$ no espaço aéreo, $23(17,04 \%)$ no dossel, $10(7,41 \%)$ no solo e $96(71,11 \%)$ no sub-bosque.

$\mathrm{O}$ registro das espécies Butorides striatus e Tigrisoma lineatum, tipicamente paludícolas e ictiófagas, foi possível através de levantamento realizado próximo à uma lagoa natural adjacente ao fragmento amarelo.

Também foi possível o registro de espécies de hábitos crepusculares e noturnos, como Tyto alba, Otus choliba, Nyctibius griseus, Hydropsalis brasiliana e Nyctidromus albicollis, justificando os levantamentos nos finais de tarde e à noite. Hábitos noturnos em aves são raros, atribuíveis a menos de 5\% da classe (Sick, 1997).

Uma espécie bastante importante e observada na área, foi Streptoprocne zonaris, tipicamente de hábito gregário, que necessita de grutas úmidas e paredões para dormir e nidificar. É uma espécie muito comum no litoral sul, frequientando grutas abertas para o lado do mar e fendas em ilhas rochosas (Becking, 1975).

A espécie Chloroceryle americana, observada principalmente próximo ao córrego que atravessa os fragmentos e o corredor, é tipicamente ictiófaga e vive em 
ambientes com vegetação densa, próximos dos cursos d'água pequenos, onde passa quase que desapercebida (Skutch, 1972).

Destacam-se no levantamento, algumas espécies umbrófilas, que habitam o interior da mata densa, como Crypturellus obsoletus, Leptotila verreauxi, Clytolaema rubricauda, Lochmias nematura e Turdus albicollis.

Segundo Höfling \& Lencioni (1992), a fauna nesta região é predominantemente umbrófila, pouco tolerante às variações de umidade relativa e da temperatura, assim como insolação elevada. A destruição e fragmentação das áreas florestais teriam o efeito imediato de eliminar das áreas afetadas praticamente toda a fauna umbrófila. A redução das áreas de florestas naturais, assim como o efeito de borda sobre os fragmentos florestais não afetam apenas a fauna das áreas perturbadas, mas também das áreas limítrofes à perturbação.

Houve o registro de um número pequeno de espécies umbrófilas nas áreas estudadas, devido principalmente à redução dos ambientes florestais, o que favoreceu o aumento em densidade das espécies adaptadas aos ambientes abertos, assim como o aparecimento de novas espécies. Buteo albicaudatus, Milvago chimachima, Plyborus planchus, Cariama cristata e Colaptes campestris, espécies típicas de ambientes abertos, foram observadas principalmente na borda dos fragmentos e corredor, competindo por espaço e alimento com as espécies florestais. 


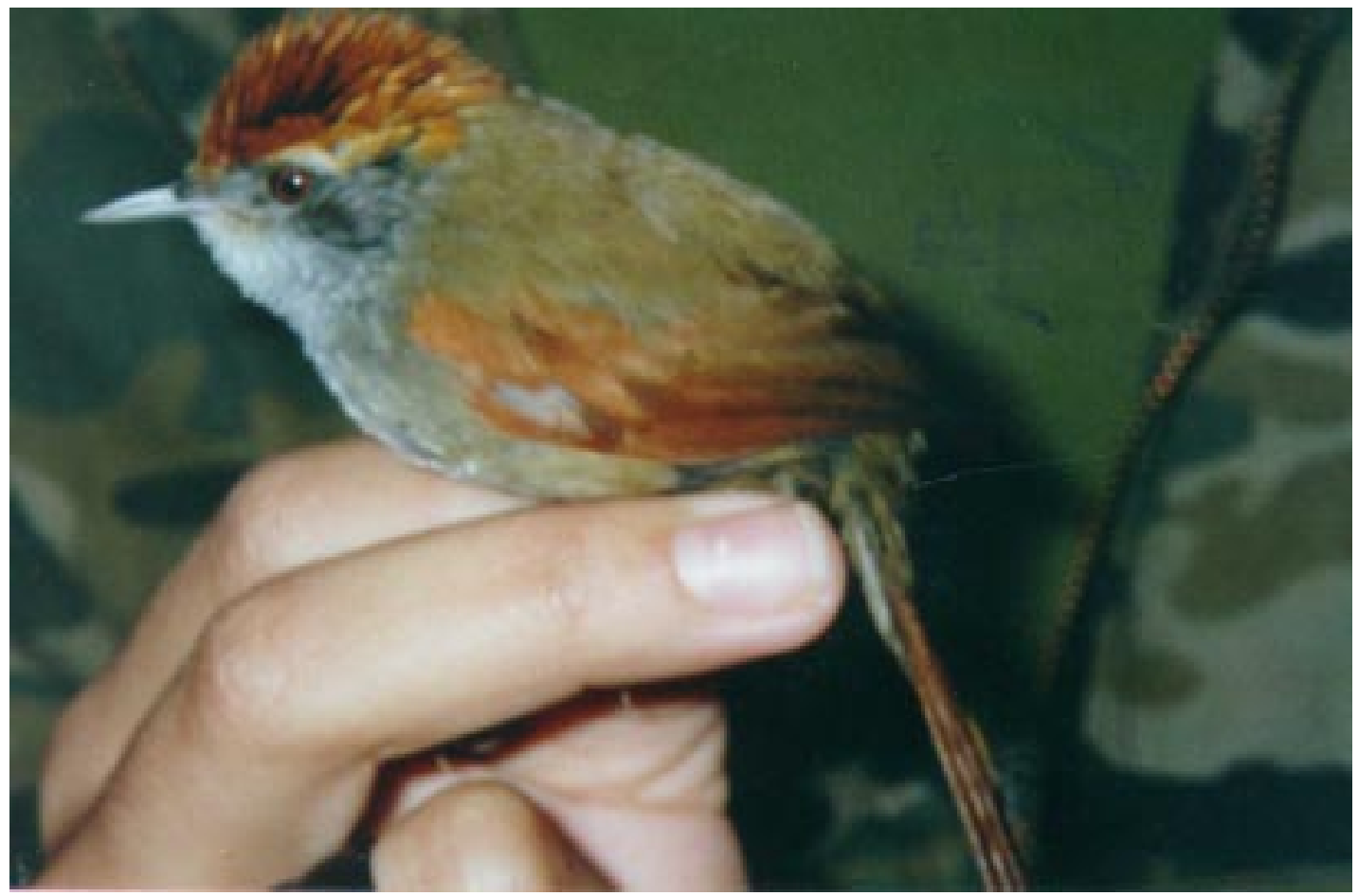

Figura 13. Synallaxis ruficapilla (joão teneném), representante da guilda insetívora.

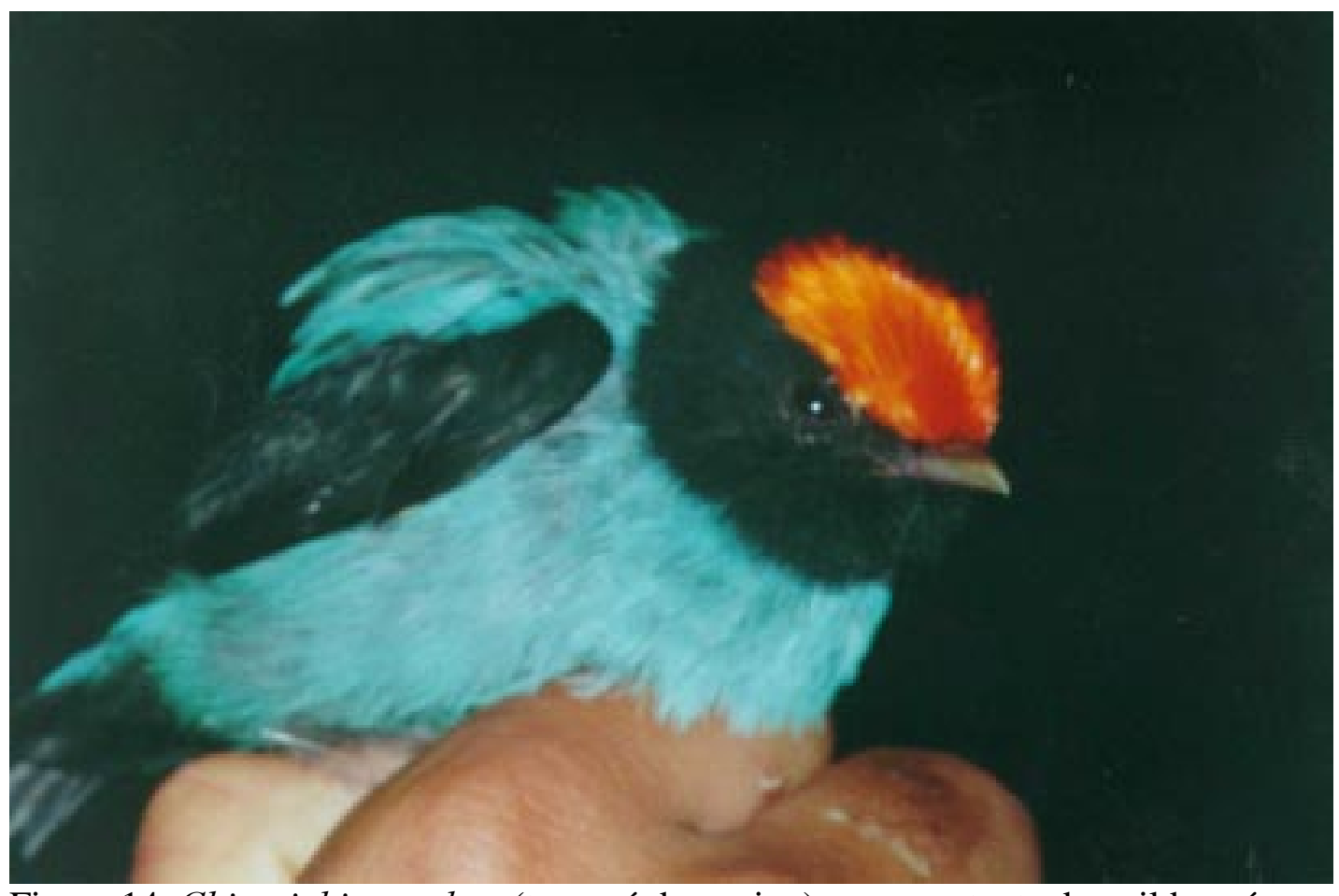

Figura 14. Chiroxiphia caudata (tangará dançarino), representante da guilda onívora. 


\subsubsection{Método de observações por pontos fixos}

\subsubsection{Quantidade de indivíduos registrados}

Através do método de observações por pontos fixos foram registradas 113 espécies, distribuídas em 27 famílias e 13 ordens, respectivamente 83,70\%, 81,82\% e $92,86 \%$ do total registrado por todos os métodos utilizados. O número total de contatos foi 3.436. Considerou-se como contato, o indivíduo registrado no dia do levantamento, podendo ter havido vários contatos com o mesmo indivíduo, desde que em dias diferentes. A relação das espécies e o número de contatos, de acordo com cada área estudada encontram-se na Tabela 09.

Tabela 09. Espécies registradas nas áreas de estudo através do método de observações por pontos fixos e número de contatos $(\mathrm{FV}=$ fragmento vermelho, $\mathrm{C}=$ corredor, $\mathrm{FA}=$ fragmento amarelo, $\mathrm{SB}=$ sub-bosque de eucalipto).

\begin{tabular}{lccccc}
\hline \multicolumn{1}{c}{ espécie } & FV & C & FA & SB & total \\
\hline Crypturellus obsoletus & 27 & 12 & 21 & - & 60 \\
Coragyps atratus & 2 & - & - & - & 2 \\
Buteo albicaudatus & - & - & 1 & - & 1 \\
Buteo brachyurus & 1 & - & - & - & 1 \\
Rupornis magnirostris & 8 & 5 & 9 & 2 & 24 \\
Herpetotheres cachinnans & - & - & 1 & - & 1 \\
Micrastur ruficollis & - & - & 1 & - & 1 \\
Milvago chimachima & 5 & 6 & 6 & 4 & 21 \\
Polyborus plancus & 1 & - & 2 & - & 3 \\
Penelope superciliaris & 1 & - & - & - & 1 \\
Rallus nigricans & 1 & 4 & 1 & - & 6 \\
Cariama cristata & 1 & - & - & - & 1 \\
Columba picazuro & - & 4 & - & 4 & 8 \\
Columbina talpacoti & 4 & 12 & 6 & 4 & 26 \\
Leptotila verreauxi & 1 & 2 & 8 & 2 & 13 \\
Pionus maximiliani & 1 & - & 4 & - & 5 \\
Piaya cayana & 8 & 4 & 4 & 2 & 18 \\
Guira guira & - & - & 4 & - & 4 \\
Nyctibius griseus & - & 2 & - & - & 2 \\
Nyctidromus albicollis & 2 & 3 & - & - & 5 \\
Phaethornis eurynome & 18 & 29 & 18 & 6 & 71 \\
Phaethornis pretrei & 3 & 4 & 1 & - & 8 \\
\hline
\end{tabular}


Tabela 09. Espécies registradas nas áreas de estudo através do método de observações por pontos fixos e número de contatos $(\mathrm{FV}=$ fragmento vermelho, $\mathrm{C}=$ corredor, $\mathrm{FA}=$ fragmento amarelo, $\mathrm{SB}=$ sub-bosque de eucalipto).

\begin{tabular}{lccccc}
\hline \multicolumn{1}{c}{ espécie } & FV & C & FA & SB & total \\
\hline Melanotrochilus fuscus & 2 & 3 & - & - & 5 \\
Stephanoxis lalandi & - & 1 & 1 & - & 2 \\
Thalurania glaucopis & 2 & 2 & - & - & 4 \\
Leucochloris albicollis & 6 & 5 & 2 & - & 13 \\
Amazilia fimbriata & 1 & 1 & 1 & - & 3 \\
Aphantochroa cirrhochloris & - & - & 1 & - & 1 \\
Chloroceryle americana & 4 & 9 & 8 & - & 21 \\
Picumnus cirratus & 4 & 5 & 6 & 2 & 17 \\
Colaptes campestris & - & 3 & 1 & 2 & 6 \\
Colaptes melanochloros & 1 & - & - & - & 1 \\
Veniliornis spilogaster & 2 & 3 & - & 1 & 6 \\
Veniliornis passerinus & 10 & 2 & 2 & - & 14 \\
Mackenziaena severa & 15 & 12 & 15 & - & 42 \\
Thamnophilus doliatus & - & 7 & 1 & 3 & 11 \\
Thamnophilus caerulescens & 58 & 29 & 50 & 9 & 146 \\
Dysithamnus mentalis & 10 & 5 & 3 & - & 18 \\
Drymophila malura & 8 & 6 & 9 & - & 23 \\
Drymophila squamata & 4 & 9 & 3 & - & 16 \\
Pyriglena leucoptera & 20 & 19 & 14 & 5 & 58 \\
Conopophaga lineata & 32 & 25 & 23 & 7 & 87 \\
Synallaxis spixi & 17 & 8 & 6 & 2 & 33 \\
Synallaxis ruficapilla & 26 & 18 & 24 & 6 & 74 \\
Phacellodomus rufifrons & 4 & - & - & - & 4 \\
Phacellodomus ferrugineigula & 3 & 8 & 7 & 2 & 20 \\
Syndactyla rufosuperciliata & 46 & 24 & 24 & 8 & 102 \\
Lochmias nematura & 19 & 24 & 19 & 9 & 71 \\
Sittasomus griseicapillus & 38 & 28 & 29 & 4 & 99 \\
Lepidocolaptes fuscus & 15 & 5 & 6 & 3 & 29 \\
Camptostoma obsoletum & 6 & - & 2 & - & 8 \\
Elaenia flavogaster & - & 12 & 2 & - & 14 \\
Elaenia parvirostris & 1 & 14 & 5 & 3 & 23 \\
Elaenia cristata & - & 4 & - & - & 4 \\
Elaenia obscura & - & - & 1 & - & 1 \\
Serpophaga subcristata & - & - & 1 & - & 1 \\
Mionectes rufiventris & 5 & - & 2 & - & 7 \\
Leptopogon amaurocephalus & 1 & - & 2 & - & 3 \\
Phylloscartes paulistus & 1 & 2 & 6 & - & 9 \\
\hline & & & & & \\
& & &
\end{tabular}


Tabela 09. Espécies registradas nas áreas de estudo através do método de observações por pontos fixos e número de contatos $(\mathrm{FV}=$ fragmento vermelho, $\mathrm{C}=$ corredor, FA = fragmento amarelo, $\mathrm{SB}=$ sub-bosque de eucalipto).

\begin{tabular}{lccccc}
\hline \multicolumn{1}{c}{ espécie } & FV & C & FA & SB & total \\
\hline Capsiempis flaveola & 2 & 4 & 1 & - & 7 \\
Myiornis auricularis & 1 & - & - & - & 1 \\
Todirostrum poliocephalum & - & 2 & 1 & - & 3 \\
Todirostrum cinereum & 10 & - & 2 & - & 12 \\
Todirostrum plumbeiceps & 46 & 23 & 15 & 6 & 90 \\
Tolmomyias sulphurescens & 30 & 17 & 17 & 5 & 69 \\
Platyrinchus mystaceus & 18 & 43 & 46 & 15 & 122 \\
Myiobius barbatus & 4 & 8 & 3 & - & 15 \\
Myiophobus fasciatus & 7 & 8 & 2 & - & 17 \\
Lathrotriccus euleri & 11 & 13 & 16 & 4 & 44 \\
Knipolegus lophotes & 1 & - & - & - & 1 \\
Knipolegus cyanirostris & 2 & - & 1 & - & 3 \\
Attila rufus & 16 & 9 & 6 & - & 31 \\
Myiarchus ferox & 7 & 3 & 1 & - & 11 \\
Pitangus sulphuratus & 18 & 23 & 9 & 9 & 59 \\
Myiozetetes similis & 2 & - & - & - & 2 \\
Empidonomus varius & 4 & - & 3 & 1 & 8 \\
Tyrannus savana & - & 4 & - & - & 4 \\
Tyrannus melancholicus & 4 & 25 & 8 & 11 & 48 \\
Pachyramphus polychopterus & 17 & 2 & 5 & 3 & 27 \\
Chiroxiphia caudata & 57 & 26 & 66 & 15 & 164 \\
Ilicura militaris & 4 & 6 & 5 & - & 15 \\
Cyanocorax cristatellus & 1 & - & - & - & 1 \\
Troglodytes aedon & 3 & 2 & - & - & 5 \\
Platycichla flavipes & 2 & 3 & 1 & - & 6 \\
Turdus rufiventris & 23 & 23 & 16 & 6 & 68 \\
Turdus amaurochalinus & 12 & 11 & 4 & 2 & 29 \\
Turdus albicollis & 7 & 4 & 3 & - & 14 \\
Cyclarhis gujanensis & 42 & 16 & 26 & 5 & 89 \\
Vireo olivaceus & 6 & 5 & - & - & 11 \\
Hylophilus poicilotis & 3 & - & - & 1 & 4 \\
Hylophilus thoracicus & - & - & 2 & - & 2 \\
Parula pitiayumi & 28 & 12 & 14 & 2 & 56 \\
Geothlypis aequinoctialis & 12 & 11 & 7 & - & 30 \\
Basileuterus culicivorus & 94 & 53 & 96 & 16 & 259 \\
Basileuterus leucoblepharus & 153 & 78 & 101 & 26 & 358 \\
Coereba flaveola & - & 2 & - & - & 2 \\
\hline & & & & & \\
& & &
\end{tabular}


Tabela 09. Espécies registradas nas áreas de estudo através do método de observações por pontos fixos e número de contatos $(\mathrm{FV}=$ fragmento vermelho, $\mathrm{C}=$ corredor, FA = fragmento amarelo, $\mathrm{SB}=$ sub-bosque de eucalipto).

\begin{tabular}{lccccc}
\hline \multicolumn{1}{c}{ espécie } & FV & C & FA & SB & total \\
\hline Hemithraupis ruficapilla & 4 & 4 & 3 & - & 11 \\
Tachyphonus coronatus & 16 & 24 & 18 & - & 58 \\
Trichothraupis melanops & 10 & 14 & 5 & 3 & 32 \\
Thraupis sayaca & 11 & 36 & 11 & - & 58 \\
Stephanophorus diadematus & - & 4 & 2 & - & 6 \\
Pipraeidea melanonota & - & 6 & - & - & 6 \\
Euphonia chlorotica & 1 & 6 & - & - & 7 \\
Tangara desmaresti & 12 & 46 & 4 & - & 62 \\
Tangara cayana & - & 2 & - & - & 2 \\
Dacnis cayana & - & 4 & - & - & 4 \\
Conirostrum speciosum & 8 & - & 2 & - & 10 \\
Zonotrichia capensis & 20 & 28 & 12 & 7 & 67 \\
Volatinia jacarina & 2 & 8 & - & - & 10 \\
Sporophila caerulescens & 16 & 39 & 14 & 8 & 77 \\
Arremon flavirostris & 1 & - & - & - & 1 \\
Saltator similis & 27 & 14 & 13 & 4 & 58 \\
Carduelis magellanicus & - & 2 & - & - & 2 \\
\multicolumn{1}{r}{ total } & 1220 & 1053 & 924 & 239 & 3436 \\
\hline
\end{tabular}

Do total de espécies registradas através do método de observações por pontos fixos, 79,65\% (90 espécies) foram registradas no fragmento vermelho, 74,34\% (84 espécies) no corredor e fragmento amarelo e 37,17\% (42 espécies) no sub-bosque de eucalipto (Tabela 10). Destas, 60,18\% (68 espécies) são comuns ao fragmento vermelho e corredor, 40,71\% (46 espécies) são comuns ao corredor e fragmento amarelo, 61,95\% (70 espécies) são comuns aos 2 fragmentos e 53,98\% (61 espécies) são comuns às 3 áreas de vegetação natural. 
Tabela 10. Número de espécies, famílias e ordens observadas em cada área estudada (FV = fragmento vermelho, $\mathrm{C}=$ corredor, $\mathrm{FA}=$ fragmento amarelo, $\mathrm{SB}=$ subbosque de eucalipto).

\begin{tabular}{cccc}
\hline área & $\mathrm{n}^{\text {0 }}$ espécies & $\mathrm{n}^{\text {0 }}$ famílias & $\mathrm{n}^{\text {o }}$ ordens \\
\hline FV & 90 & 24 & 13 \\
C & 84 & 22 & 10 \\
FA & 84 & 19 & 10 \\
SB & 42 & 15 & 6 \\
\hline
\end{tabular}

Das espécies registradas pelo método de observações por pontos fixos, 8,85\% (10 espécies) são exclusivas do fragmento vermelho, 7,96\% (9 espécies) são exclusivas do corredor, 7,08\% (8 espécies) são exclusivas do fragmento amarelo, não havendo nenhuma espécie exclusiva do sub-bosque de eucalipto. Das 46 espécies observadas no sub-bosque de eucalipto, 36 espécies (78,26\%) são comuns às 3 áreas de vegetação natural.

O método de observações por pontos fixos permitiu o registro de um maior número indivíduos e espécies, comparado com o método de captura e recaptura com redes neblina. $\mathrm{O}$ fato ocorre em função da distribuição das aves nos diferentes estratos florestais, sendo que todos os indivíduos e espécies existentes nestes diferentes estratos são passíveis de serem observados. O método também permite o registro através de vocalizações, sem que haja contato visual.

Através deste método, foram registradas 64 espécies de aves, 13 famílias e 7 ordens (Tinamiformes, Ciconiiformes, Galliformes, Gruiformes, Psittaciformes, Cuculiformes e Caprimulgiformes), que não foram constatadas pelo método de captura e recaptura, somadas a outras 21 espécies, 6 famílias e a ordem Strigiformes, registradas apenas através do método qualitativo.

Nota-se portanto, que algumas destas espécies, que só puderam ser registradas através de observações, possuem características que dificultam sua captura e recaptura através de redes neblina, como as que freqüentam preferencialmente o dossel da mata (Rupornis magnirostris, Milvago chimachima, Veniliornis spilogaster, Pitangus sulphuratus, Tyrannus savana), àquelas com hábitos predominantemente terrícolas 
(Crypturellus obsoletus), as de hábitos noturnos (Speotyto cunicularia, Nyctibius griseus, Nyctidromus albicolis), as que habitam áreas de brejo (Porzana albicollis, Rallus nigricans) e as que apresentam movimentação através de curtos deslocamentos (Troglodytes aedon).

Na Tabela 11, observa-se que o índice de densidade geral para as 3 áreas de vegetação natural foi de 47,95 indivíduos constatados a cada hora de observação. Este índice foi calculado separadamente, considerando-se as 3 áreas de vegetação natural e o sub-bosque de eucalipto, resultando em 56,30 indivíduos por hora no fragmento vermelho, 48,59 indivíduos por hora no corredor, 39,60 indivíduos por hora no fragmento amarelo e 17,93 indivíduos por hora no sub-bosque de eucalipto.

Tabela 11. Índice de densidade geral para as áreas estudadas ( $F V=$ fragmento vermelho, $\mathrm{C}=$ corredor, $\mathrm{FA}=$ fragmento amarelo, $\mathrm{SB}=$ sub-bosque de eucalipto).

\begin{tabular}{cc}
\hline área & $\mathrm{n}^{\mathrm{o}}$ ind/hora \\
\hline $\mathrm{FV}$ & 56,30 \\
$\mathrm{C}$ & 48,59 \\
$\mathrm{FA}$ & 39,60 \\
$\mathrm{FV}+\mathrm{C}+\mathrm{FA}$ & 47,95 \\
$\mathrm{SB}$ & 17,93 \\
\hline
\end{tabular}

Nota-se a baixa densidade apresentada no sub-bosque de eucalipto, quando comparamos com as áreas de vegetação natural. $\mathrm{O}$ fato reforça a teoria de que a alta diversidade da vegetação e o número de estratos definidos estão diretamente ligados à diversidade e densidade da fauna.

\subsubsection{Curvas do número acumulado de espécies}

Na Figura 15 são apresentadas as curvas do número acumulado de espécies para as 4 áreas estudadas, onde observa-se a estabilização das curvas, coincidindo com o período final do levantamento. Através do resultado, conclui-se que as horas utilizadas para o método de observações por pontos fixos foram suficientes para o registro da maioria das espécies da avifauna existentes nas áreas estudadas. Considerando-se as 4 
áreas, 69,0\% das espécies registradas foram observadas pela primeira vez nas primeiras 20 horas de levantamento, $18,6 \%$ nas 20 horas seguintes, $8,0 \%$ nas outras 20 horas e 4,4\% nas últimas 20 horas. Ao longo do ano, houve um acréscimo esperado no número de espécies observadas, influenciado principalmente pela variação climática, florescimento e frutificação de determinadas espécies vegetais e provável perturbação ocasionada pelas atividades florestais próximas da área de estudo.

Figura 15. Curvas do número acumulado de espécies para as áreas estudadas $(\mathrm{FV}=$ fragmento vermelho, $\mathrm{C}=$ corredor, $\mathrm{FA}=$ fragmento amarelo, $\mathrm{SB}=$ subbosque de eucalipto).

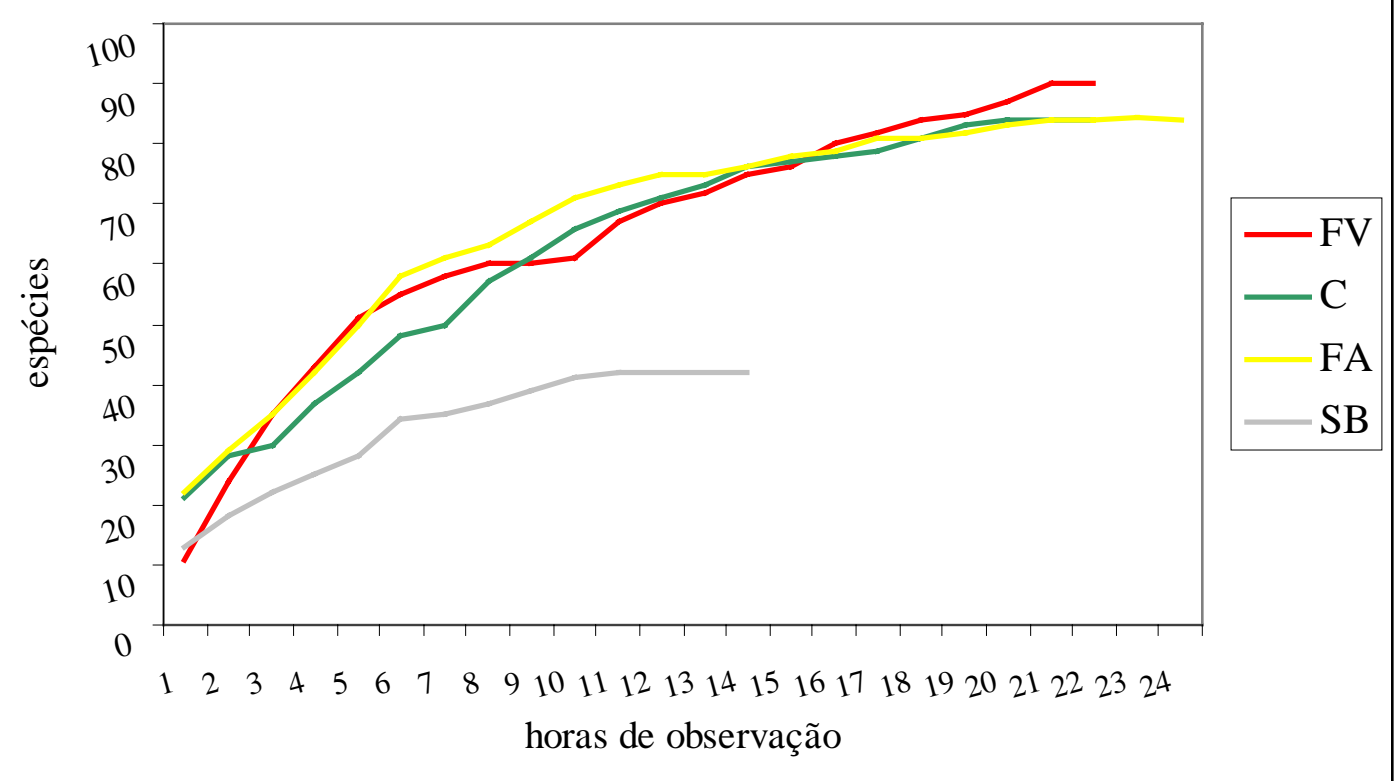




\subsubsection{3 Índice pontual de abundância (IPA)}

Através do índice pontual de abundância obteve-se uma densidade estimada das espécies registradas através do método de observações por pontos fixos (Tabela 12).

Tabela 12. Índice pontual de abundância (IPA) para as espécies registradas em cada área estudada $(\mathrm{FV}=$ fragmento vermelho, $\mathrm{C}=$ corredor, $\mathrm{FA}=$ fragmento amarelo, $\mathrm{SB}=$ sub-bosque de eucalipto).

\begin{tabular}{|c|c|c|c|c|c|c|c|}
\hline espécie & FV & $\mathrm{C}$ & FA & SB & $\overline{\mathrm{FV}+\mathrm{FA}}$ & $\mathrm{FV}+\mathrm{C}+\mathrm{FA}$ & total \\
\hline Crypturellus obsoletus & 0,4154 & 0,1846 & 0,3000 & - & 0,3556 & 0,3000 & 0,2500 \\
\hline Coragyps atratus & 0,0308 & - & - & - & 0,0148 & 0,0100 & 0,0083 \\
\hline Buteo albicaudatus & - & - & 0,0143 & - & 0,0074 & 0,0050 & 0,0042 \\
\hline Buteo brachyurus & 0,0154 & - & - & - & 0,0074 & 0,0050 & 0,0042 \\
\hline Rupornis magnirostris & 0,1231 & 0,0769 & 0,1286 & 0,0500 & 0,1259 & 0,1100 & 0,1000 \\
\hline Herpetotheres cachinnans & - & - & 0,0143 & - & 0,0074 & 0,0050 & 0,0042 \\
\hline Micrastur ruficollis & - & - & 0,0143 & - & 0,0074 & 0,0050 & 0,0042 \\
\hline Milvago chimachima & 0,0769 & 0,0923 & 0,0857 & 0,1000 & 0,0815 & 0,0850 & 0,0875 \\
\hline Polyborus plancus & 0,0154 & - & 0,0286 & - & 0,0222 & 0,0150 & 0,0125 \\
\hline Penelope superciliaris & 0,0154 & - & - & - & 0,0074 & 0,0050 & 0,0042 \\
\hline Rallus nigricans & 0,0154 & 0,0615 & 0,0143 & - & 0,0148 & 0,0300 & 0,0250 \\
\hline Cariama cristata & 0,0154 & - & - & - & 0,0074 & 0,0050 & 0,0042 \\
\hline Columba picazuro & - & 0,0615 & - & 0,1000 & - & 0,0200 & 0,0333 \\
\hline Columbina talpacoti & 0,0615 & 0,1846 & 0,0857 & 0,1000 & 0,0741 & 0,1100 & 0,1083 \\
\hline Leptotila verreauxi & 0,0154 & 0,0308 & 0,1143 & 0,0500 & 0,0667 & 0,0550 & 0,0542 \\
\hline Pionus maximiliani & 0,0154 & - & 0,0571 & - & 0,0370 & 0,0250 & 0,0208 \\
\hline ayana & 0,1231 & 0,0615 & 0,0571 & 0,0500 & 0,0889 & 0,0800 & 0,0750 \\
\hline Guira & - & - & 0,0571 & - & 0,0296 & 0,0200 & 0,0167 \\
\hline Nyctibius griseus & - & 0,0308 & - & - & & 0,0100 & 0,0083 \\
\hline Nyctidromus albicollis & 0,0308 & 0,0462 & - & - & 0,0148 & 0,0250 & 0,0208 \\
\hline Phaethornis eurynome & 0,2769 & 0,4462 & 0,2571 & 0,1500 & 0,2667 & 0,3250 & 0,2958 \\
\hline Phaethornis pretrei & 0,0462 & 0,0615 & 0,0143 & - & 0,0296 & 0,0400 & 0,0333 \\
\hline Melanotrochilus fuscus & 0,0308 & 0,0462 & - & - & 0,0148 & 0,0250 & 0,0208 \\
\hline Stephanoxis lalandi & - & 0,0154 & 0,0143 & - & 0,0074 & 0,0100 & 0,0083 \\
\hline Thalurania glaucopis & 0,0308 & 0,0308 & - & - & 0,0148 & 0,0200 & 0,0167 \\
\hline Leucochloris albicollis & 0,0923 & 0,0769 & 0,0286 & - & 0,0593 & 0,0650 & 0,0542 \\
\hline Amazilia fimbriata & 0,0154 & 0,0154 & 0,0143 & - & 0,0148 & 0,0150 & 0,0125 \\
\hline Aphantochroa cirrhochloris & - & - & 0,0143 & - & 0,0074 & 0,0050 & 0,0042 \\
\hline Chloroceryle americana & 0,0615 & 0,1385 & 0,1143 & - & 0,0889 & 0,1050 & 0,0875 \\
\hline Picumnus cirratus & 0,0615 & 0,0769 & 0,0857 & 0,0500 & 0,0741 & 0,0750 & 0,0708 \\
\hline Colaptes campestris & - & 0,0462 & 0,0143 & 0,0500 & 0,0074 & 0,0200 & 0,0250 \\
\hline Colaptes melanochloros & 0,0154 & - & - & - & 0,0074 & 0,0050 & 0,0042 \\
\hline Veniliornis spilogaster & 0,0308 & 0,0462 & - & 0,0250 & 0,0148 & 0,0250 & 0,0250 \\
\hline
\end{tabular}


Tabela 12. Índice pontual de abundância (IPA) para as espécies registradas em cada área estudada $(\mathrm{FV}=$ fragmento vermelho, $\mathrm{C}=$ corredor, $\mathrm{FA}=$ fragmento amarelo, $\mathrm{SB}=$ sub-bosque de eucalipto).

\begin{tabular}{|c|c|c|c|c|c|c|c|}
\hline espécie & FV & $\mathrm{C}$ & FA & SB & $\mathrm{FV}+\mathrm{FA}$ & $\mathrm{FV}+\mathrm{C}+\mathrm{FA}$ & total \\
\hline Veniliornis spilogaster & 0,0308 & 0,0462 & - & 0,0250 & 0,0148 & 0,0250 & 0,0250 \\
\hline Mackenziaena severa & 0,2308 & 0,1846 & 0,2143 & - & 0,2222 & 0,2100 & 0,1750 \\
\hline Thamnophilus doliatus & - & 0,1077 & 0,0143 & 0,0750 & 0,0074 & 0,0400 & 0,0458 \\
\hline Thamnophilus caerulescens & 0,8923 & 0,4462 & 0,7143 & 0,2250 & 0,8000 & 0,6850 & 0,6083 \\
\hline Dysithamnus mentalis & 0,1538 & 0,0769 & 0,0429 & - & 0,0963 & 0,0900 & 0,0750 \\
\hline Drymophila malura & 0,1231 & 0,0923 & 0,1286 & - & 0,1259 & 0,1150 & 0,0958 \\
\hline Drymophila squamata & 0,0615 & 0,1385 & 0,0429 & - & 0,0519 & 0,0800 & 0,0667 \\
\hline Pyriglena leucoptera & 0,3077 & 0,2923 & 0,2000 & 0,1250 & 0,2519 & 0,2650 & 0,2417 \\
\hline Conopophaga lineata & 0,4923 & 0,3846 & 0,3286 & 0,1750 & 0,4074 & 0,4000 & 0,3625 \\
\hline Synallaxis spixi & 0,2615 & 0,1231 & 0,0857 & 0,0500 & 0,1704 & 0,1550 & 0,1375 \\
\hline Synallaxis ruficapilla & 0,4000 & 0,2769 & 0,3429 & 0,1500 & 0,3704 & 0,3400 & 0,3083 \\
\hline Phacellodomus rufifrons & 0,0615 & - & - & - & 0,0296 & 0,0200 & 0,0167 \\
\hline Phacellodomus ferrugineigula & 0,0462 & 0,1231 & 0,1000 & 0,0500 & 0,0741 & 0,0900 & 0,0833 \\
\hline Syndactyla rufosuperciliata & 0,7077 & 0,3692 & 0,3429 & 0,2000 & 0,5185 & 0,4700 & 0,4250 \\
\hline Lochmias nematura & 0,2923 & 0,3692 & 0,2714 & 0,2250 & 0,2815 & 0,3100 & 0,2958 \\
\hline Sittasomus griseicapillus & 0,5846 & 0,4308 & 0,4143 & 0,1000 & 0,4963 & 0,4750 & 0,4125 \\
\hline Lepidocolaptes fuscus & 0,2308 & 0,0769 & 0,0857 & 0,0750 & 0,1556 & 0,1300 & 0,1208 \\
\hline Camptostoma obsoletum & 0,0923 & - & 0,0286 & - & 0,0593 & 0,0400 & 0,0333 \\
\hline Elaenia flavogaster & - & 0,1846 & 0,0286 & - & 0,0148 & 0,0700 & 0,0583 \\
\hline Elaenia parvirostris & 0,0154 & 0,2154 & 0,0714 & 0,0750 & 0,0444 & 0,1000 & 0,0958 \\
\hline Elaenia cristata & - & 0,0615 & - & - & - & 0,0200 & 0,0167 \\
\hline Elaenia obscura & - & - & 0,0143 & - & 0,0074 & 0,0050 & 0,0042 \\
\hline Serpophaga subcristata & - & - & 0,0143 & - & 0,0074 & 0,0050 & 0,0042 \\
\hline Mionectes rufiventris & 0,0769 & - & 0,0286 & - & 0,0519 & 0,0350 & 0,0292 \\
\hline Leptopogon amaurocephalus & 0,0154 & - & 0,0286 & - & 0,0222 & 0,0150 & 0,0125 \\
\hline Phylloscartes paulistus & 0,0154 & 0,0308 & 0,0857 & - & 0,0519 & 0,0450 & 0,0375 \\
\hline Capsiempis flaveola & 0,0308 & 0,0615 & 0,0143 & - & 0,0222 & 0,0350 & 0,0292 \\
\hline Myiornis auricularis & 0,0154 & - & - & - & 0,0074 & 0,0050 & 0,0042 \\
\hline Todirostrum poliocephalum & - & 0,0308 & 0,0143 & - & 0,0074 & 0,0150 & 0,0125 \\
\hline Todirostrum cinereum & 0,1538 & - & 0,0286 & - & 0,0889 & 0,0600 & 0,0500 \\
\hline Todirostrum plumbeiceps & 0,7077 & 0,3538 & 0,2143 & 0,1500 & 0,4519 & 0,4200 & 0,3750 \\
\hline Tolmomyias sulphurescens & 0,4615 & 0,2615 & 0,2429 & 0,1250 & 0,3481 & 0,3200 & 0,2875 \\
\hline Platyrinchus mystaceus & 0,2769 & 0,6615 & 0,6571 & 0,3750 & 0,4741 & 0,5350 & 0,5083 \\
\hline Myiobius barbatus & 0,0615 & 0,1231 & 0,0429 & - & 0,0519 & 0,0750 & 0,0625 \\
\hline Myiophobus fasciatus & 0,1077 & 0,1231 & 0,0286 & - & 0,0667 & 0,0850 & 0,0708 \\
\hline Lathrotriccus euleri & 0,1692 & 0,2000 & 0,2286 & 0,1000 & 0,2000 & 0,2000 & 0,1833 \\
\hline Knipolegus lophotes & 0,0154 & - & - & - & 0,0074 & 0,0050 & 0,0042 \\
\hline Knipolegus cyanirostris & 0,0308 & - & 0,0143 & - & 0,0222 & 0,0150 & 0,0125 \\
\hline Attila rufus & 0,2462 & 0,1385 & 0,0857 & - & 0,1630 & 0,1550 & 0,1292 \\
\hline Myiarchus ferox & 0,1077 & 0,0462 & 0,0143 & - & 0,0593 & 0,0550 & 0,0458 \\
\hline Pitangus sulphuratus & 0,2769 & 0,3538 & 0,1286 & 0,2250 & 0,2000 & 0,2500 & 0,2458 \\
\hline
\end{tabular}


Tabela 12. Índice pontual de abundância (IPA) para as espécies registradas em cada área estudada $(\mathrm{FV}=$ fragmento vermelho, $\mathrm{C}=$ corredor, $\mathrm{FA}=$ fragmento amarelo, $\mathrm{SB}=$ sub-bosque de eucalipto).

\begin{tabular}{|c|c|c|c|c|c|c|c|}
\hline espécie & $\mathrm{FV}$ & $\mathrm{C}$ & FA & SB & $\mathrm{FV}+\mathrm{FA}$ & $\mathrm{FV}+\mathrm{C}+\mathrm{FA}$ & total \\
\hline Myiozetetes similis & 0,0308 & - & - & - & 0,0148 & 0,0100 & 0,0083 \\
\hline Empidonomus varius & 0,0615 & - & 0,0429 & 0,0250 & 0,0519 & 0,0350 & 0,0333 \\
\hline Tyrannus savana & - & 0,0615 & - & - & - & 0,0200 & 0,0167 \\
\hline Tyrannus melancholicus & 0,0615 & 0,3846 & 0,1143 & 0,2750 & 0,0889 & 0,1850 & 0,2000 \\
\hline Pachyramphus polychopterus & 0,2615 & 0,0308 & 0,0714 & 0,0750 & 0,1630 & 0,1200 & 0,1125 \\
\hline Chiroxiphia caudata & 0,8769 & 0,4000 & 0,9429 & 0,3750 & 0,9111 & 0,7450 & 0,6833 \\
\hline Ilicura militaris & 0,0615 & 0,0923 & 0,0714 & - & 0,0667 & 0,0750 & 0,0625 \\
\hline Cyanocorax cristatellus & 0,0154 & - & - & - & 0,0074 & 0,0050 & 0,0042 \\
\hline Troglodytes aedon & 0,0462 & 0,0308 & - & - & 0,0222 & 0,0250 & 0,0208 \\
\hline Platycichla flavipes & 0,0308 & 0,0462 & 0,0143 & - & 0,0222 & 0,0300 & 0,0250 \\
\hline Turdus rufiventris & 0,3538 & 0,3538 & 0,2286 & 0,1500 & 0,2889 & 0,3100 & 0,2833 \\
\hline Turdus amaurochalinus & 0,1846 & 0,1692 & 0,0571 & 0,0500 & 0,1185 & 0,1350 & 0,1208 \\
\hline Turdus albicollis & 0,1077 & 0,0615 & 0,0429 & - & 0,0741 & 0,0700 & 0,0583 \\
\hline Cyclarhis gujanensis & 0,6462 & 0,2462 & 0,3714 & 0,1250 & 0,5037 & 0,4200 & 0,3708 \\
\hline Vireo olivaceus & 0,0923 & 0,0769 & - & - & 0,0444 & 0,0550 & 0,0458 \\
\hline Hylophilus poicilotis & 0,0462 & - & - & 0,0250 & 0,0222 & 150 & 0,0167 \\
\hline Hylophilus thoracicus & - & - & 0,0286 & - & 0,0148 & 0,0100 & 0,0083 \\
\hline Parula pitiayumi & 0,4308 & 0,1846 & 0,2000 & 0,0500 & 0,3111 & 0,2700 & 0,2333 \\
\hline Geothlypis aequinoctialis & 0,1846 & 0,1692 & 0,1000 & - & 0,1407 & 0,1500 & 0,1250 \\
\hline Basileuterus culicivorus & 1,4462 & 0,8154 & 1,3714 & 0,4000 & 1,4074 & 1,2150 & 1,0792 \\
\hline Basileuterus leucoblepharus & 2,3538 & 1,2000 & 1,4429 & 0,6500 & 1,8815 & 600 & 1,4917 \\
\hline Coereba flaveola & - & 0,0308 & - & - & - & 0,0100 & 0,0083 \\
\hline Hemithraupis ruficapilla & 0,0615 & 0,0615 & 0,0429 & - & 0,0519 & 0,0550 & 0,0458 \\
\hline Tachyphonus coronatus & 0,2462 & 0,3692 & 0,2571 & - & 0,2519 & 0,2900 & 0,2417 \\
\hline Trichothraupis melanops & 0,1538 & 0,2154 & 0,0714 & 0,0750 & 0,1111 & 0,1450 & 0,1333 \\
\hline Thraupis sayaca & 0,1692 & 0,5538 & 0,1571 & - & 0,1630 & 0,2900 & 0,2417 \\
\hline Stephanophorus diadematus & - & 0,0615 & 0,0286 & - & 0,0148 & 0,0300 & 0,0250 \\
\hline Pipraeidea melanonota & - & 0,0923 & - & - & - & 0,0300 & 0,0250 \\
\hline Euphonia chlorotica & 0,0154 & 0,0923 & - & - & 0,0074 & 0,0350 & 0,0292 \\
\hline Tangara desmaresti & 0,1846 & 0,7077 & 0,0571 & - & 0,1185 & 0,3100 & 0,2583 \\
\hline Tangara cayana & - & 0,0308 & - & - & - & 0,0100 & 0,0083 \\
\hline Dacnis cayana & - & 0,0615 & - & - & - & 0,0200 & 0,0167 \\
\hline Conirostrum speciosum & 0,1231 & - & 0,0286 & - & 0,0741 & 0,0500 & 0,0417 \\
\hline Zonotrichia capensis & 0,3077 & 0,4308 & 0,1714 & 0,1750 & 0,2370 & 0,3000 & 0,2792 \\
\hline Volatinia jacarina & 0,0308 & 0,1231 & - & - & 0,0148 & 0,0500 & 0,0417 \\
\hline Sporophila caerulescens & 0,2462 & 0,6000 & 0,2000 & 0,2000 & 0,2222 & 0,3450 & 0,3208 \\
\hline Arremon flavirostris & 0,0154 & - & - & - & 0,0074 & 0,0050 & 0,0042 \\
\hline Saltator similis & 0,4154 & 0,2154 & 0,1857 & 0,1000 & 0,2963 & 0,2700 & 0,2417 \\
\hline Carduelis magellanicus & - & 0,0308 & - & - & - & 0,0100 & 0,0083 \\
\hline
\end{tabular}


O IPA variou para o conjunto das áreas, de 0,0042 a 1,4917, ou seja, de 1 a 358 registros, em 80 horas de observação, sendo as espécies de maior abundância, Basileuterus leucoblepharus (1,4917), Basileuterus culicivorus (1,0792), Chiroxiphia caudata (0,6833), Thamnophilus caerulescens (0,6083), Platyrinchus mystaceus (0,5083), Syndactyla rufosuperciliata (0,4250), Sittasomus griseicapillus (0,4125), Todirostrum plumbeiceps (0,3750), Cyclarhis gujanensis (0,3708) e Conopophaga lineata $(0,3625)$. Estas espécies ocupam predominantemente o sub-bosque da floresta, e com exceção da Chiroxiphia caudata (onívora), todas pertencem à guilda insetívora.

Das espécies observadas, 19 possuem IPA maior que 0,2500, ou seja, foram registradas no mínimo 60 vezes em 80 horas de observação, 30 possuem IPA entre 0,0625 e 0,2458 (entre 15 e 59 registros), 50 tiveram de 2 a 14 registros e 14 apenas 1 registro.

As 51 espécies de maior IPA para o conjunto das áreas de vegetação natural, são comuns nas 3 áreas. Este fato mostra a homogeneidade destas áreas em relação à diversidade da avifauna. As espécies Basileuterus leucoblepharus e Basileuterus culicivorus são as mais abundantes em todas as áreas estudadas.

Algumas espécies pouco abundantes nos fragmentos, têm grande destaque no corredor, como o Tangara desmaresti, com o $3^{\text {o }}$ maior IPA $(0,7077)$, Sporophila caerulescens com o $5^{\mathrm{o}}(0,6000)$, Thraupis sayaca com o $6^{\mathrm{o}}(0,5538)$ e Zonotrichia capensis com o $10^{-}(0,4308)$ O fato das espécies onívoras e granívoras de sub-bosque terem maior densidade no corredor é devido ao maior efeito de borda que este ambiente está sofrendo, pois possui estreita faixa de vegetação natural. A maior incidência de luz neste ambiente, proporciona maior produção de frutos e de plantas invasoras produtoras de sementes. Ao longo do ano, observou-se algumas árvores e arbustos produzindo frutos que serviram de alimento para diversas espécies da avifauna. Entre estas espécies vegetais destacamos o Schinus terebinthifolius, Copaifera langsdorffii, Cecropia pachystachia, Alchornea glandulosa, Alchornea triplinervia, Ocotea puberula, Ocotea pulchella, Miconia spp, Inga sessilis, Ficus sp, Rapanea ferruginea, Eugenia sp, Gomidesia affinis, Myrcia sp e Trema micrantha. 
No sub-bosque de eucalipto destacam-se as espécies que possuem boa adaptação aos ambientes antropisados, como o Tyrannus melancholicus com o $5^{-}$maior IPA $(0,2750)$, Pitangus sulphuratus com o $8^{\circ}(0,2250)$ e Sporophila caerulescens com o $10^{\circ}(0,2000)$. No entanto, espécies tipicamente florestais e que tiveram bastante destaque nos ambientes que vegetação natural, não foram observadas no eucalipto, como o Crypturellus obsoletus, Mackenziana severa, Dysithamnus mentalis, Drymophila malura, Drymophila squamata, Phylloscartes paulistus, Todirostrum cinereum, Myiobius barbatus, Myiophobus fasciatus, Attila rufus, Myiarchus ferox, Ilicura militaris, Geothlypis aequinoctialis, Hemithraupis ruficapilla e Tachyphonus coronatus. Tal fato demonstra que o plantio de eucalipto, mesmo com o sub-bosque bastante desenvolvido, constitui-se numa barreira para as espécies da avifauna, principalmente as florestais.

Das 113 espécies observadas, 71 não tiveram sua ocorrência registrada no sub-bosque de eucalipto. Se utilizarmos a metodologia aplicada por Berndt (1993), para determinar as espécies de aves adaptadas aos reflorestamentos, comparadas com áreas de vegetação natural, apenas 7 espécies das 113 observadas estariam adaptadas às áreas com plantio de eucalipto: Columba picazuro, Colaptes campestris, Thamnophilus doliatus, Hylophilus poicilotis, Tyrannus melancholicus, Milvago chimachima e Veniliornis spilogaster. Nota-se nesta relação a ausência de espécies onívoras de subbosque e de espécies tipicamente florestais.

A fórmula utilizada consiste na divisão entre o IPA de determinada espécie no sub-bosque de eucalipto pelo IPA da mesma, nas áreas de vegetação natural, subtraindo-se 1 . O valor resultante desta relação, sendo positivo, indica que a espécie em questão estaria teoricamente bem adaptada ao reflorestamento, e o contrário poder-se-ia supor para valor negativo. Aplicando-se a metodologia para o corredor, 57 das 113 espécies registradas não estariam adaptadas a este ambiente.

As espécies mais abundantes no sub-bosque de eucalipto pertencem a guilda insetívora. Em apenas um foco de lepidópteros desfolhadores de eucalipto, Almeida \& Alves (1982a) registraram a presença de 26 espécies de aves insetívoras combatendo intensamente as lagartas e mariposas. 
Nota-se uma ampla variação nos tamanhos das populações das aves observadas, nos 4 ambientes estudados. Das 113 espécies registradas pelo método de observações por pontos fixos, 61 espécies $(53,98 \%)$ são comuns às 3 áreas de vegetação natural. Destas 61 espécies, 36 são as que possuem as maiores densidades populacionais no fragmento vermelho, 31 possuem as maiores densidades populacionais no corredor e 47 possuem as maiores densidades populacionais no fragmento amarelo.

Dentre as espécies mais comuns nas 3 áreas de vegetação natural e de maiores densidades populacionais destacamos Basileuterus leucoblepharus, Basileuterus culicivorus, Thamnophilus caerulescens, Chiroxiphia caudata, Syndactyla rufosuperciliata, Sittasomus griseicapillus, Conopophaga lineata, Turdus rufiventris, Platyrinchus mystaceus e Phaethornis eurynome. É importante ressaltar que, apesar da predominância de espécies da guilda insetívora, há também, entre as espécies mais populosas, representantes das guildas onívora e néctar-insetívora.

As 10 espécies mais abundantes em estudos realizados por Toledo (1993) foram Crypturellus obsoletus, Baryphthengus ruficapilla, Drymophila ferruginea, Pionus maximiliani, Chamaeza campanisoma, Pyrrhura frontalis, Leptotila rufaxilla, Chiroxiphia caudata, Myrmeciza squamosa e Sittasomus griseicapillus. Nota-se que, apesar desta região estudada também estar localizada na Mata Atlântica do Estado de São Paulo, há uma diversidade bastante diferente quando comparamos com as áreas de vegetação natural do presente estudo.

As espécies da fauna da Mata Atlântica não possuem uma distribuição uniforme em toda a sua extensão, podendo uma espécie ser abundante em uma região e rara na região adjacente (Höfling \& Lencioni, 1992).

Para as 4 áreas estudadas, há uma predominância de espécies e indivíduos pertencentes à guilda insetívora e que ocupam o sub-bosque da floresta, seguindo-se os onívoros e granívoros que também ocupam o mesmo ambiente, mostrando a importância da existência do sub-bosque, principalmente nos plantios de eucalipto, onde a diversidade vegetal geralmente é menor. A presença das espécies granívoras está relacionada com a grande disponibilidade de sementes proporcionada pelas gramíneas presentes nas bordas e clareiras das áreas estudadas (Tabela 13, Figuras 16 e 17). 
Tabela 13. Número de espécies (n) e porcentagem dos indivíduos (i) de diferentes guildas alimentares observados em cada área estudada $(\mathrm{FV}=$ fragmento vermelho, $\mathrm{C}=$ corredor, $\mathrm{FA}=$ fragmento amarelo, $\mathrm{SB}=$ sub-bosque de eucalipto).

\begin{tabular}{cccccccccr}
\hline guilda alimentar & \multicolumn{2}{c}{$\mathrm{FV}$} & \multicolumn{3}{c}{$\mathrm{C}$} & \multicolumn{3}{c}{$\mathrm{FA}$} & \multicolumn{3}{c}{$\mathrm{SB}$} \\
insetívora de sub-bosque & $\mathrm{n}$ & $\mathrm{i}$ & $\mathrm{n}$ & $\mathrm{i}$ & $\mathrm{n}$ & $\mathrm{i}$ & \multicolumn{1}{c}{$\mathrm{n}$} & $\mathrm{i}$ \\
onívora de sub-bosque & 40 & 64,59 & 37 & 52,61 & 41 & 63,96 & 20 & 57,32 \\
granívora de sub-bosque & 14 & 17,21 & 14 & 22,22 & 14 & 17,86 & 5 & 12,97 \\
insetívora de dossel & 7 & 5,82 & 7 & 9,97 & 5 & 5,73 & 5 & 10,46 \\
néctar-insetívora de sub-bosque & 7 & 3,93 & 5 & 5,51 & 4 & 2,71 & 5 & 10,46 \\
onívora de solo & 6 & 2,62 & 8 & 4,46 & 6 & 2,60 & 1 & 2,51 \\
inseto-carnívora de dossel & 2 & 2,29 & 2 & 1,52 & 2 & 2,38 & - & - \\
onívora de dossel & 3 & 1,88 & 2 & 1,42 & 5 & 3,03 & 2 & 3,35 \\
outras & 4 & 0,74 & 4 & 1,52 & 1 & 0,32 & 1 & 0,42 \\
total & 7 & 0,92 & 5 & 0,77 & 6 & 1,41 & 3 & 2,51 \\
& 90 & 100 & 84 & 100 & 84 & 100 & 42 & 100 \\
\hline
\end{tabular}

Figura 16. Número de espécies de cada guilda alimentar presente nas áreas estudadas

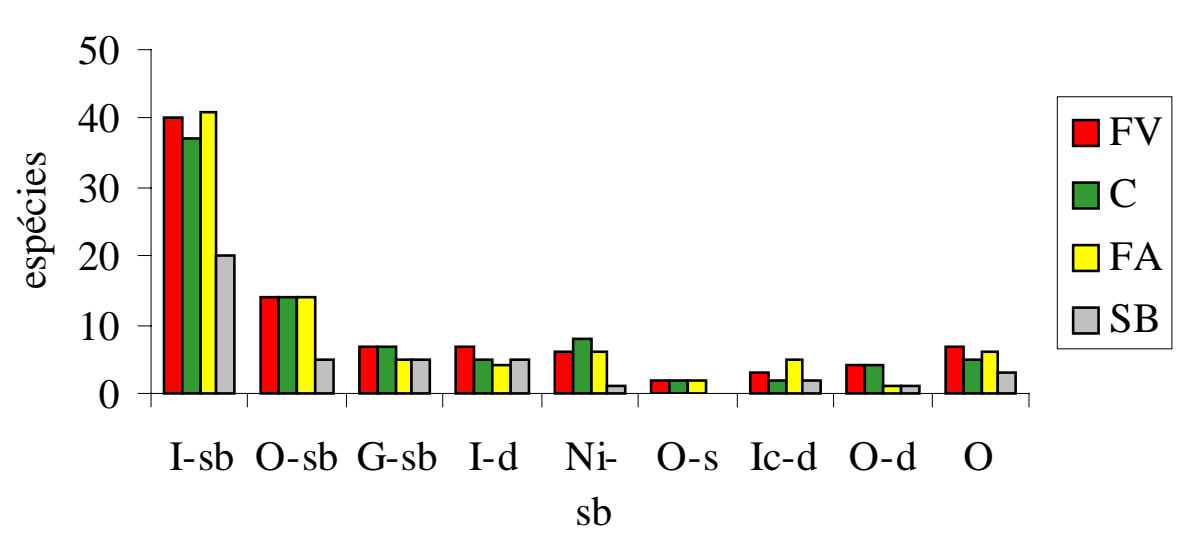

guildas alimentares

Legenda:

Áreas estudadas: $\mathrm{FV}=$ fragmento vermelho, $\mathrm{C}=$ corredor, $\mathrm{FA}=$ fragmento amarelo, $\mathrm{SB}$ $=$ sub-bosque de eucalipto

Guildas alimentares: I-sb = insetívora de sub-bosque, O-sb = onívora de sub-bosque, G$\mathrm{sb}=$ granívora de sub-bosque, I-d = insetívora de dossel, Ni-sb = néctar-insetívora de sub-bosque, O-s = onívora de solo, $\mathrm{Ic}-\mathrm{d}=$ inseto-carnívora de dossel, O-d = onívora de dossel, $\mathrm{O}=$ outras 
Figura 17. Porcentagem dos indivíduos de cada guilda alimentar observados nas áreas estudadas

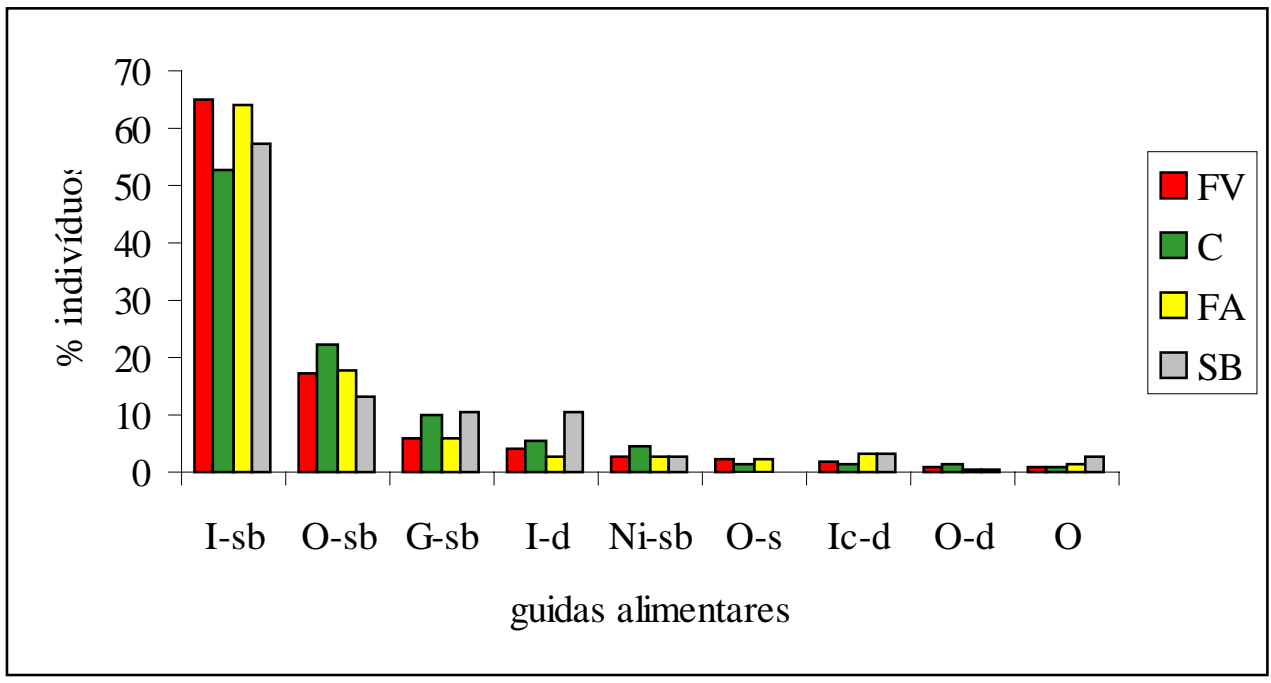

Legenda:

Áreas estudadas: $\mathrm{FV}=$ fragmento vermelho, $\mathrm{C}=$ corredor, $\mathrm{FA}=$ fragmento amarelo, $\mathrm{SB}$ $=$ sub-bosque de eucalipto

Guildas alimentares: I-sb = insetívora de sub-bosque, O-sb = onívora de sub-bosque, G$\mathrm{sb}=$ granívora de sub-bosque, I-d = insetívora de dossel, $\mathrm{Ni}-\mathrm{sb}=$ néctar-insetívora de sub-bosque, O-s = onívora de solo, Ic-d = inseto-carnívora de dossel, $\mathrm{O}-\mathrm{d}=$ onívora de dossel, $\mathrm{O}=$ outras 


\subsubsection{Freqüência de ocorrência (FO)}

Através da freqüência de ocorrência obteve-se a frequiência de cada espécie para cada ambiente estudado (Tabela 14).

Tabela 14. Freqüência de ocorrência (FO) para as espécies registradas em cada área estudada $(\mathrm{FV}=$ fragmento vermelho, $\mathrm{C}=$ corredor, $\mathrm{FA}=$ fragmento amarelo, $\mathrm{SB}=$ sub-bosque de eucalipto).

\begin{tabular}{lrrrrr}
\hline \multicolumn{1}{c}{ espécie } & \multicolumn{1}{c}{ FV } & \multicolumn{1}{c}{ C } & \multicolumn{1}{c}{ FA } & SB & total \\
\hline Crypturellus obsoletus & 33,85 & 18,46 & 28,57 & - & 22,50 \\
Coragyps atratus & 1,54 & - & - & - & 0,42 \\
Buteo albicaudatus & - & - & 1,43 & - & 0,42 \\
Buteo brachyurus & 1,54 & - & - & - & 0,42 \\
Rupornis magnirostris & 12,31 & 7,69 & 12,86 & 5,00 & 10,00 \\
Herpetotheres cachinnans & - & - & 1,43 & - & 0,42 \\
Micrastur ruficollis & - & - & 1,43 & - & 0,42 \\
Milvago chimachima & 7,69 & 9,23 & 8,57 & 10,00 & 8,75 \\
Polyborus plancus & 1,54 & - & 2,86 & - & 1,25 \\
Penelope superciliaris & 1,54 & - & - & - & 0,42 \\
Rallus nigricans & 1,54 & 6,15 & 1,43 & - & 2,50 \\
Cariama cristata & 1,54 & - & - & - & 0,42 \\
Columba picazuro & - & 4,62 & - & 10,00 & 2,92 \\
Columbina talpacoti & 3,08 & 12,31 & 4,29 & 2,50 & 5,83 \\
Leptotila verreauxi & 1,54 & 3,08 & 11,43 & 5,00 & 5,42 \\
Pionus maximiliani & 1,54 & - & 1,43 & - & 0,83 \\
Piaya cayana & 12,31 & 6,15 & 5,71 & 5,00 & 7,50 \\
Guira guira & - & - & 2,86 & - & 0,83 \\
Nyctibius griseus & - & 3,08 & - & - & 0,83 \\
Nyctidromus albicollis & 3,08 & 4,62 & - & - & 2,08 \\
Phaethornis eurynome & 24,62 & 40,00 & 22,86 & 12,50 & 26,25 \\
Phaethornis pretrei & 4,62 & 6,15 & 1,43 & - & 3,33 \\
Melanotrochilus fuscus & 3,08 & 4,62 & - & - & 2,08 \\
Stephanoxis lalandi & - & 1,54 & 1,43 & - & 0,83 \\
Thalurania glaucopis & 3,08 & 3,08 & - & - & 1,67 \\
Leucochloris albicollis & 9,23 & 7,69 & 2,86 & - & 5,42 \\
Amazilia fimbriata & 1,54 & 1,54 & 1,43 & - & 1,25 \\
Aphantochroa cirrhochloris & - & - & 1,43 & - & 0,42 \\
Chloroceryle americana & 6,15 & 12,31 & 11,43 & - & 8,33 \\
Picumnus cirratus & 4,62 & 7,69 & 7,14 & 5,00 & 6,25 \\
Colaptes campestris & - & 4,62 & 1,43 & 5,00 & 2,50 \\
\hline & & & & &
\end{tabular}


Tabela 14. Freqüência de ocorrência (FO) para as espécies registradas em cada área estudada $(\mathrm{FV}=$ fragmento vermelho, $\mathrm{C}=$ corredor, $\mathrm{FA}=$ fragmento amarelo, $\mathrm{SB}=$ sub-bosque de eucalipto).

\begin{tabular}{lrrrrr}
\hline \multicolumn{1}{c}{ espécie } & \multicolumn{1}{c}{$\mathrm{FV}$} & $\mathrm{C}$ & $\mathrm{FA}$ & $\mathrm{SB}$ & total \\
\hline Colaptes melanochloros & 1,54 & - & - & - & 0,42 \\
Veniliornis spilogaster & 3,08 & 4,62 & - & 2,50 & 2,50 \\
Veniliornis passerinus & 13,85 & 1,54 & 2,86 & - & 5,00 \\
Mackenziaena severa & 16,92 & 16,92 & 14,29 & - & 13,33 \\
Thamnophilus doliatus & - & 9,23 & 1,43 & 7,50 & 4,17 \\
Thamnophilus caerulescens & 78,46 & 38,46 & 62,86 & 17,50 & 52,92 \\
Dysithamnus mentalis & 13,85 & 6,15 & 4,29 & - & 6,67 \\
Drymophila malura & 9,23 & 7,69 & 10,00 & - & 7,50 \\
Drymophila squamata & 4,62 & 9,23 & 4,29 & - & 5,00 \\
Pyriglena leucoptera & 27,69 & 24,62 & 18,57 & 12,50 & 21,67 \\
Conopophaga lineata & 46,15 & 33,85 & 28,57 & 17,50 & 32,92 \\
Synallaxis spixi & 24,62 & 9,23 & 7,14 & 5,00 & 12,08 \\
Synallaxis ruficapilla & 35,38 & 26,15 & 30,00 & 15,00 & 27,92 \\
Phacellodomus rufifrons & 6,15 & - & - & - & 1,67 \\
Phacellodomus ferrugineigula & 4,62 & 10,77 & 10,00 & 5,00 & 7,92 \\
Syndactyla rufosuperciliata & 66,15 & 33,85 & 28,57 & 20,00 & 38,75 \\
Lochmias nematura & 27,69 & 33,85 & 27,14 & 22,50 & 28,33 \\
Sittasomus griseicapillus & 53,85 & 36,92 & 37,14 & 10,00 & 37,08 \\
Lepidocolaptes fuscus & 21,54 & 6,15 & 5,71 & 7,50 & 10,42 \\
Camptostoma obsoletum & 9,23 & - & 2,86 & - & 3,33 \\
Elaenia flavogaster & - & 10,77 & 2,86 & - & 3,75 \\
Elaenia parvirostris & 1,54 & 13,85 & 4,29 & 7,50 & 6,67 \\
Elaenia cristata & - & 6,15 & - & - & 1,67 \\
Elaenia obscura & - & - & 1,43 & - & 0,42 \\
Serpophaga subcristata & - & - & 1,43 & - & 0,42 \\
Mionectes rufiventris & 7,69 & - & 2,86 & - & 2,92 \\
Leptopogon amaurocephalus & 1,54 & - & 2,86 & - & 1,25 \\
Phylloscartes paulistus & 1,54 & 3,08 & 8,57 & - & 3,75 \\
Capsiempis flaveola & 3,08 & 6,15 & 1,43 & - & 2,92 \\
Myiornis auricularis & 1,54 & - & - & - & 0,42 \\
Todirostrum poliocephalum & - & 3,08 & 1,43 & - & 1,25 \\
Todirostrum cinereum & 12,31 & - & 2,86 & - & 4,17 \\
Todirostrum plumbeiceps & 61,54 & 32,31 & 18,57 & 15,00 & 33,33 \\
Tolmomyias sulphurescens & 40,00 & 23,08 & 20,00 & 10,00 & 24,58 \\
Platyrinchus mystaceus & 18,46 & 33,85 & 32,86 & 20,00 & 27,08 \\
Myiobius barbatus & 6,15 & 12,31 & 4,29 & - & 6,25 \\
Myiophobus fasciatus & 10,77 & 12,31 & 2,86 & - & 7,08 \\
\hline & & & & &
\end{tabular}


Tabela 14. Freqüência de ocorrência (FO) para as espécies registradas em cada área estudada $(\mathrm{FV}=$ fragmento vermelho, $\mathrm{C}=$ corredor, $\mathrm{FA}=$ fragmento amarelo, $\mathrm{SB}=$ sub-bosque de eucalipto).

\begin{tabular}{lrrrrr}
\hline \multicolumn{1}{c}{ espécie } & $\mathrm{FV}$ & \multicolumn{1}{c}{$\mathrm{C}$} & $\mathrm{FA}$ & $\mathrm{SB}$ & total \\
\hline Lathrotriccus euleri & 15,38 & 18,46 & 20,00 & 10,00 & 16,67 \\
Knipolegus lophotes & 1,54 & - & - & - & 0,42 \\
Knipolegus cyanirostris & 3,08 & - & 1,43 & - & 1,25 \\
Attila rufus & 23,08 & 13,85 & 8,57 & - & 12,50 \\
Myiarchus ferox & 10,77 & 4,62 & 1,43 & - & 4,58 \\
Pitangus sulphuratus & 16,92 & 26,15 & 10,00 & 12,50 & 16,67 \\
Myiozetetes similis & 3,08 & - & - & - & 0,83 \\
Empidonomus varius & 6,15 & - & 4,29 & 2,50 & 3,33 \\
Tyrannus savana & - & 6,15 & - & - & 1,67 \\
Tyrannus melancholicus & 4,62 & 27,69 & 8,57 & 17,50 & 14,17 \\
Pachyramphus polychopterus & 23,08 & 3,08 & 7,14 & 7,50 & 10,42 \\
Chiroxiphia caudata & 63,08 & 20,00 & 57,14 & 22,50 & 42,92 \\
Ilicura militaris & 6,15 & 6,15 & 5,71 & - & 5,00 \\
Cyanocorax cristatellus & 1,54 & - & - & - & 0,42 \\
Troglodytes aedon & 4,62 & 3,08 & - & - & 2,08 \\
Platycichla flavipes & 3,08 & 4,62 & 1,43 & - & 2,50 \\
Turdus rufiventris & 32,31 & 30,77 & 20,00 & 15,00 & 25,42 \\
Turdus amaurochalinus & 18,46 & 16,92 & 5,71 & 5,00 & 12,08 \\
Turdus albicollis & 10,77 & 6,15 & 4,29 & - & 5,83 \\
Cyclarhis gujanensis & 64,62 & 23,08 & 35,71 & 12,50 & 36,25 \\
Vireo olivaceus & 7,69 & 6,15 & - & - & 3,75 \\
Hylophilus poicilotis & 4,62 & - & - & 2,50 & 1,67 \\
Hylophilus thoracicus & - & - & 2,86 & - & 0,83 \\
Parula pitiayumi & 36,92 & 15,38 & 15,71 & 5,00 & 19,58 \\
Geothlypis aequinoctialis & 15,38 & 13,85 & 7,14 & - & 10,00 \\
Basileuterus culicivorus & 80,00 & 58,46 & 84,29 & 22,50 & 65,83 \\
Basileuterus leucoblepharus & 86,15 & 64,62 & 87,14 & 47,50 & 74,17 \\
Coereba flaveola & - & 3,08 & - & - & 0,83 \\
Hemithraupis ruficapilla & 3,08 & 3,08 & 2,86 & - & 2,50 \\
Tachyphonus coronatus & 18,46 & 29,23 & 20,00 & - & 18,75 \\
Trichothraupis melanops & 12,31 & 15,38 & 5,71 & 7,50 & 10,42 \\
Thraupis sayaca & 12,31 & 36,92 & 8,57 & - & 15,83 \\
Stephanophorus diadematus & - & 4,62 & 2,86 & - & 2,08 \\
Pipraeidea melanonota & - & 6,15 & - & - & 1,67 \\
Euphonia chlorotica & 7,69 & 27,69 & 2,86 & - & 10,42 \\
Tangara desmaresti & - & 1,54 & - & - & 0,42 \\
Tangara cayana & 3,08 & - & - & 0,83 \\
Dacnis cayana & & & &
\end{tabular}


Tabela 14. Freqüência de ocorrência (FO) para as espécies registradas em cada área estudada $(\mathrm{FV}=$ fragmento vermelho, $\mathrm{C}=$ corredor, $\mathrm{FA}=$ fragmento amarelo, $\mathrm{SB}=$ sub-bosque de eucalipto).

\begin{tabular}{lrrrrr}
\hline \multicolumn{1}{c}{ espécie } & FV & C & FA & SB & total \\
\hline Conirostrum speciosum & 12,31 & - & 2,86 & - & 4,17 \\
Zonotrichia capensis & 27,69 & 33,85 & 14,29 & 15,00 & 23,33 \\
Volatinia jacarina & 1,54 & 7,69 & - & - & 2,50 \\
Sporophila caerulescens & 15,38 & 38,46 & 10,00 & 10,00 & 19,17 \\
Arremon flavirostris & 1,54 & - & - & - & 0,42 \\
Saltator similis & 40,00 & 21,54 & 17,14 & 10,00 & 23,33 \\
Carduelis magellanicus & - & 1,54 & - & - & 0,42 \\
\hline
\end{tabular}

Nos 2 fragmentos, as 10 espécies mais abundantes são as mais freqüentes, estando o Basileuterus leucoblepharus e Basileuterus culicivorus com freqüência de ocorrência acima de $80 \%$.

No corredor, Basileuterus leucoblepharus e Basileuterus culicivorus também são as mais frequientes, mas algumas espécies de grande abundância neste ambiente, como o Tangara desmaresti, que se alimenta basicamente de frutos, tiveram sua freqüência condicionada a época de frutificação de algumas árvores.

Outras espécies onívoras, com menor abundância nas áreas de vegetação natural, como Platycichla flavipes, Vireo olivaceus, Hemithraupis ruficapilla, Stephanophorus diadematus, Pipraeidea melanonota, Euphonia chlorotica, Tangara cayana, Dacnis cayana e Conirostrum speciosum só puderam ser observadas em determinadas épocas do ano, coincidindo com a época de frutificação de determinadas espécies arbóreas e arbustivas, mostrando haver uma relação de freqüência de algumas espécies da avifauna com a floração e frutificação dos vegetais existentes. Nenhuma destas espécies onívoras foram observadas no sub-bosque de eucalipto, mesmo sendo bem desenvolvido e constituído por diversas espécies arbustivas produtoras de frutos.

No sub-bosque de eucalipto, Basileuterus leucoblepharus e Basileuterus culicivorus também são as mais freqüentes, mas nota-se que tanto a abundância quanto a 
freqüência das espécies neste ambiente é bastante inferior quando comparamos com os ambientes de vegetação natural.

Algumas espécies tiveram abundância e freqüência abaixo do esperado, e outras simplesmente não foram registradas, como as espécies da família Psittacidae, muito comuns nas florestas e capoeiras da Mata Atlântica.

A freqüência de ocorrência é eficiente apenas para espécies comuns e abundantes, devido à sua conspicuidade ou densidade, podendo haver uma subestimativa ou mesmo a exclusão de espécies raras, pela freqüência de dias (Kendeigh, 1944).

\subsubsection{5. Índice de Kendeigh (IK)}

Através da freqüência de ocorrência, que expressa a frequiência relativa das espécies, e o número médio de indivíduos registrados, pode-se estimar o tamanho da população atual para cada espécie. A Tabela 15 apresenta os índices de Kendeigh para cada espécie em cada área estudada.

Tabela 15. Índice de Kendeigh (IK) para as espécies registradas em cada área estudada $(\mathrm{FV}=$ fragmento vermelho, $\mathrm{C}=$ corredor, $\mathrm{FA}=$ fragmento amarelo, $\mathrm{SB}=$ sub-bosque de eucalipto).

\begin{tabular}{lccccc}
\hline \multicolumn{1}{c}{ espécie } & FV & C & FA & SB & total \\
\hline Crypturellus obsoletus & 6,45 & 4,30 & 5,48 & - & 5,00 \\
Coragyps atratus & 1,75 & - & - & - & 0,91 \\
Buteo albicaudatus & - & - & 1,20 & - & 0,65 \\
Buteo brachyurus & 1,24 & - & - & - & 0,65 \\
Rupornis magnirostris & 3,51 & 2,77 & 3,59 & 2,24 & 3,16 \\
Herpetotheres cachinnans & - & - & 1,20 & - & 0,65 \\
Micrastur ruficollis & - & - & 1,20 & - & 0,65 \\
Milvago chimachima & 2,77 & 3,04 & 2,93 & 3,16 & 2,96 \\
Polyborus plancus & 1,24 & - & 1,69 & - & 1,12 \\
Penelope superciliaris & 1,24 & - & - & - & 0,65 \\
Cariama cristata & 1,24 & - & - & - & 0,65 \\
Rallus nigricans & 1,24 & 2,48 & 1,20 & - & 1,58 \\
Columba picazuro & - & 2,48 & - & 3,16 & 1,83 \\
Columbina talpacoti & 2,48 & 4,30 & 2,93 & 3,16 & 3,29 \\
Leptotila verreauxi & 1,24 & 1,75 & 3,38 & 2,24 & 2,33 \\
Pionus maximiliani & 1,24 & - & 2,39 & - & 1,44 \\
Piaya cayana & 3,51 & 2,48 & 2,39 & 2,24 & 2,74 \\
\hline
\end{tabular}


Tabela 15. Índice de Kendeigh (IK) para as espécies registradas em cada área estudada $(\mathrm{FV}=$ fragmento vermelho, $\mathrm{C}=$ corredor, $\mathrm{FA}=$ fragmento amarelo, $\mathrm{SB}=$ sub-bosque de eucalipto).

\begin{tabular}{lccccc}
\hline \multicolumn{1}{c}{ espécie } & FV & C & FA & SB & total \\
\hline Guira guira & - & - & 2,39 & - & 1,29 \\
Nyctibius griseus & - & 1,75 & - & - & 0,91 \\
Nyctidromus albicollis & 1,75 & 2,15 & - & - & 1,44 \\
Phaethornis eurynome & 5,26 & 6,68 & 5,07 & 3,87 & 5,44 \\
Phaethornis pretrei & 2,15 & 2,48 & 1,20 & - & 1,83 \\
Melanotrochilus fuscus & 1,75 & 2,15 & - & - & 1,44 \\
Stephanoxis lalandi & - & 1,24 & 1,20 & - & 0,91 \\
Thalurania glaucopis & 1,75 & 1,75 & - & - & 1,29 \\
Leucochloris albicollis & 3,04 & 2,77 & 1,69 & - & 2,33 \\
Amazilia fimbriata & 1,24 & 1,24 & 1,20 & - & 1,12 \\
Aphantochroa cirrhochloris & - & - & 1,20 & - & 0,65 \\
Chloroceryle americana & 2,48 & 3,72 & 3,38 & - & 2,96 \\
Picumnus cirratus & 2,48 & 2,77 & 2,93 & 2,24 & 2,66 \\
Colaptes campestris & - & 2,15 & 1,20 & 2,24 & 1,58 \\
Colaptes melanochloros & 1,24 & - & - & - & 0,65 \\
Veniliornis spilogaster & 1,75 & 2,15 & - & 1,58 & 1,58 \\
Veniliornis passerinus & 3,92 & 1,75 & 1,69 & - & 2,42 \\
Mackenziaena severa & 4,80 & 4,30 & 4,63 & - & 4,18 \\
Thamnophilus doliatus & & 3,28 & 1,20 & 2,74 & 2,14 \\
Thamnophilus caerulescens & 9,45 & 6,68 & 8,45 & 4,74 & 7,80 \\
Dysithamnus mentalis & 3,92 & 2,77 & 2,07 & - & 2,74 \\
Drymophila malura & 3,51 & 3,04 & 3,59 & - & 3,10 \\
Drymophila squamata & 2,48 & 3,72 & 2,07 & - & 2,58 \\
Pyriglena leucoptera & 5,55 & 5,41 & 4,47 & 3,54 & 4,92 \\
Conopophaga lineata & 7,02 & 6,20 & 5,73 & 4,18 & 6,02 \\
Synallaxis spixi & 5,11 & 3,51 & 2,93 & 2,24 & 3,71 \\
Synallaxis ruficapilla & 6,32 & 5,26 & 5,86 & 3,87 & 5,55 \\
Phacellodomus rufifrons & 2,48 & - & - & - & 1,29 \\
Phacellodomus ferrugineigula & 2,15 & 3,51 & 3,16 & 2,24 & 2,89 \\
Syndactyla rufosuperciliata & 8,41 & 6,08 & 5,86 & 4,47 & 6,52 \\
Lochmias nematura & 5,41 & 6,08 & 5,21 & 4,74 & 5,44 \\
Sittasomus griseicapillus & 7,65 & 6,56 & 6,44 & 3,16 & 6,42 \\
Lepidocolaptes fuscus & 4,80 & 2,77 & 2,93 & 2,74 & 3,48 \\
Camptostoma obsoletum & 3,04 & - & 1,69 & - & 1,83 \\
Elaenia flavogaster & - & 4,30 & 1,69 & - & 2,42 \\
Elaenia parvirostris & 1,24 & 4,64 & 2,67 & 2,74 & 3,10 \\
Elaenia cristata & - & 2,48 & - & - & 1,29 \\
Elaenia obscura & - & - & 1,20 & - & 0,65 \\
Serpophaga subcristata & - & - & 1,20 & - & 0,65 \\
\hline & & & & & \\
& &
\end{tabular}


Tabela 15. Índice de Kendeigh (IK) para as espécies registradas em cada área estudada $(\mathrm{FV}=$ fragmento vermelho, $\mathrm{C}=$ corredor, $\mathrm{FA}=$ fragmento amarelo, $\mathrm{SB}=$ sub-bosque de eucalipto).

\begin{tabular}{lccccc}
\hline \multicolumn{1}{c}{ espécie } & FV & C & FA & SB & total \\
\hline Mionectes rufiventris & 2,77 & - & 1,69 & - & 1,71 \\
Leptopogon amaurocephalus & 1,24 & & 1,69 & - & 1,12 \\
Phylloscartes paulistus & 1,24 & 1,75 & 2,93 & - & 1,94 \\
Capsiempis flaveola & 1,75 & 2,48 & 1,20 & - & 1,71 \\
Myiornis auricularis & 1,24 & - & - & - & 0,65 \\
Todirostrum poliocephalum & - & 1,75 & 1,20 & - & 1,12 \\
Todirostrum cinereum & 3,92 & - & 1,69 & - & 2,24 \\
Todirostrum plumbeiceps & 8,41 & 5,95 & 4,63 & 3,87 & 6,12 \\
Tolmomyias sulphurescens & 6,79 & 5,11 & 4,93 & 3,54 & 5,36 \\
Platyrinchus mystaceus & 5,26 & 8,13 & 8,11 & 6,12 & 7,13 \\
Myiobius barbatus & 2,48 & 3,51 & 2,07 & - & 2,50 \\
Myiophobus fasciatus & 3,28 & 3,51 & 1,69 & - & 2,66 \\
Lathrotriccus euleri & 4,11 & 4,47 & 4,78 & 3,16 & 4,28 \\
Knipolegus lophotes & 1,24 & - & - & - & 0,65 \\
Knipolegus cyanirostris & 1,75 & - & 1,20 & - & 1,12 \\
Attila rufus & 4,96 & 3,72 & 2,93 & - & 3,59 \\
Myiarchus ferox & 3,28 & 2,15 & 1,20 & - & 2,14 \\
Pitangus sulphuratus & 5,26 & 5,95 & 3,59 & 4,74 & 4,96 \\
Myiozetetes similis & 1,75 & - & - & - & 0,91 \\
Empidonomus varius & 2,48 & - & 2,07 & 1,58 & 1,83 \\
Tyrannus savana & - & 2,48 & - & - & 1,29 \\
Tyrannus melancholicus & 2,48 & 6,20 & 3,38 & 5,24 & 4,47 \\
Pachyramphus polychopterus & 5,11 & 1,75 & 2,67 & 2,74 & 3,35 \\
Chiroxiphia caudata & 9,36 & 6,32 & 9,71 & 6,12 & 8,27 \\
Ilicura militaris & 2,48 & 3,04 & 2,67 & - & 2,50 \\
Cyanocorax cristatellus & 1,24 & - & - & - & 0,65 \\
Troglodytes aedon & 2,15 & 1,75 & - & - & 1,44 \\
Platycichla flavipes & 1,75 & 2,15 & 1,20 & - & 1,58 \\
Turdus rufiventris & 5,95 & 5,95 & 4,78 & 3,87 & 5,32 \\
Turdus amaurochalinus & 4,30 & 4,11 & 2,39 & 2,24 & 3,48 \\
Turdus albicollis & 3,28 & 2,48 & 2,07 & - & 2,42 \\
Cyclarhis gujanensis & 8,04 & 4,96 & 6,09 & 3,54 & 6,09 \\
Vireo olivaceus & 3,04 & 2,77 & - & - & 2,14 \\
Hylophilus poicilotis & 2,15 & - & - & 1,58 & 1,29 \\
Hylophilus thoracicus & - & - & 1,69 & - & 0,91 \\
Parula pitiayumi & 6,56 & 4,30 & 4,47 & 2,24 & 4,83 \\
Geothlypis aequinoctialis & 4,30 & 4,11 & 3,16 & - & 3,54 \\
Basileeterus culicivorus & 12,03 & 9,03 & 11,71 & 6,32 & 10,39 \\
Basileuterus leucoblepharus & 15,34 & 10,95 & 12,01 & 8,06 & 12,21 \\
\hline & & & & & \\
& & &
\end{tabular}


Tabela 15. Índice de Kendeigh (IK) para as espécies registradas em cada área estudada $(\mathrm{FV}=$ fragmento vermelho, $\mathrm{C}=$ corredor, $\mathrm{FA}=$ fragmento amarelo, $\mathrm{SB}=$ sub-bosque de eucalipto).

\begin{tabular}{lccccc}
\hline \multicolumn{1}{c}{ espécie } & FV & C & FA & SB & total \\
\hline Coereba flaveola & - & 1,75 & - & - & 0,91 \\
Hemithraupis ruficapilla & 2,48 & 2,48 & 2,07 & - & 2,14 \\
Tachyphonus coronatus & 4,96 & 6,08 & 5,07 & - & 4,92 \\
Trichothraupis melanops & 3,92 & 4,64 & 2,67 & 2,74 & 3,65 \\
Thraupis sayaca & 4,11 & 7,44 & 3,96 & - & 4,92 \\
Stephanophorus diadematus & - & 2,48 & 1,69 & - & 1,58 \\
Pipraeidea melanonota & - & 3,04 & - & - & 1,58 \\
Euphonia chlorotica & 1,24 & 3,04 & - & - & 1,71 \\
Tangara desmaresti & 4,30 & 8,41 & 2,39 & - & 5,08 \\
Tangara cayana & - & 1,75 & - & - & 0,91 \\
Dacnis cayana & - & 2,48 & - & - & 1,29 \\
Conirostrum speciosum & 3,51 & - & 1,69 & - & 2,04 \\
Zonotrichia capensis & 5,55 & 6,56 & 4,14 & 4,18 & 5,28 \\
Volatinia jacarina & 1,75 & 3,51 & - & - & 2,04 \\
Sporophila caerulescens & 4,96 & 7,75 & 4,47 & 4,47 & 5,66 \\
Arremon flavirostris & 1,24 & - & - & - & 0,65 \\
Saltator similis & 6,45 & 4,64 & 4,31 & 3,16 & 4,92 \\
Carduelis magellanicus & - & 1,75 & - & - & 0,91 \\
\hline
\end{tabular}

As 10 espécies que apresentaram populações mais abundantes pelo IK em cada ambiente foram:

Fragmento vermelho: Basileuterus leucoblepharus (15,34), Basileuterus culicivorus (12,03), Thamnophilus caerulescens (9,45), Chiroxiphia caudata $(9,36)$, Syndactyla rufosuperciliata (8,41), Todirostrum plumbeiceps (8,41), Cyclarhis gujanensis (7,65), Sittasomus griseicapillus (7,02), Conopophaga lineata $(7,02)$ e Tolmomyias sulphurescens $(6,79)$.

Fragmento amarelo: Basileuterus leucoblepharus (12,01), Basileuterus culicivorus (11,71), Chiroxiphia caudata (9,71), Thamnophilus caerulescens $(8,45)$, Platyrinchus mystaceus $(8,11)$, Sittasomus griseicapillus $(6,44)$, Cyclarhis gujanensis $(6,09)$, Syndactyla rufosuperciliata $(5,86)$, Synallaxis ruficapilla $(5,86)$ e Conopophaga lineata $(5,73)$. 
Corredor: Basileuterus leucoblepharus (10,95), Basileuterus culicivorus (9,03), Tangara desmaresti (8,41), Platyrinchus mystaceus (8,13), Sporophila caerulescens (7,75), Thraupis sayaca (7,44), Thamnophilus caerulescens $(6,68)$, Phaethornis eurynome $(6,68)$, Sittasomus griseicapillus $(6,56)$ e Zonotrichia capensis $(6,56)$.

Sub-bosque de eucalipto: Basileuterus leucoblepharus (8,06), Basileuterus culicivorus (6,32), Platyrinchus mystaceus (6,12), Chiroxiphia caudata (6,12), Tyrannus melancholicus (5,24), Thamnophilus caerulescens $(4,74)$, Lochmias nematura (4,74), Pitangus sulphuratus $(4,74)$, Syndactyla rufosuperciliata $(4,47)$ e Sporophila caerulescens $(4,47)$.

Nota-se na Tabela 16, uma ampla variação nos tamanhos das populações das aves observadas, nos 4 ambientes estudados.

Tabela 16. Número de populações da avifauna para os 4 ambientes estudados, de acordo com as distribuições dos índices de Kendeigh ( $\mathrm{FV}=$ fragmento vermelho, $\mathrm{C}=$ corredor, $\mathrm{FA}=$ fragmento amarelo, $\mathrm{SB}=$ sub-bosque de eucalipto).

\begin{tabular}{cccc}
\hline área & IK $>6$ & $2>\mathrm{IK} \leq 6$ & $\mathrm{IK} \leq 2$ \\
\hline $\mathrm{FV}$ & 14 & 49 & 27 \\
$\mathrm{C}$ & 16 & 55 & 13 \\
$\mathrm{FA}$ & 7 & 48 & 29 \\
$\mathrm{SB}$ & 4 & 35 & 3 \\
\hline
\end{tabular}

\subsubsection{6 Índice de diversidade de Shannon-Weaver (H')}

Através do método de amostragem por pontos fixos (IPA) obteve-se a estimativa da abundância de cada espécie da avifauna. Desta maneira, pode-se calcular o índice de diversidade de Shannon-Weaver (Tabela 17). 
Tabela 17. Índice de diversidade de Shannon-Weaver $\left(\mathrm{H}^{\prime}\right)$ calculado para as áreas estudadas $(\mathrm{FV}=$ fragmento vermelho, $\mathrm{C}=$ corredor, $\mathrm{FA}=$ fragmento amarelo, $\mathrm{SB}=$ sub-bosque de eucalipto).

\begin{tabular}{cc}
\hline área & H'$^{\prime}$ \\
\hline FV & 3,77 \\
C & 3,98 \\
FA & 3,68 \\
SB & 3,44 \\
\hline
\end{tabular}

O índice de diversidade de Shannon-Weaver $\left(\mathrm{H}^{\prime}\right)$ nos permite conhecer o grau de heterogeneidade das áreas estudadas, sendo adotado especificamente para populações de aves, um valor compreendido entre 1,8 e 5,2 (Machado, 1996).

$\mathrm{O} \mathrm{H}^{\prime}$ variou de 3,44 a 3,98, indicando uma riqueza expressiva das áreas estudadas, com uma diversidade mais baixa para o sub-bosque de eucalipto, como era esperado, devido principalmente à baixa diversidade da vegetação.

Comparando-se o H' para as áreas de vegetação natural, que variou de 3,68 a 3,98, com os resultados obtidos por Toledo (1993), Machado (1996) e Allegrini (1997), em diferentes regiões de Mata Atlântica, nota-se que os resultados são muito semelhantes.

Toledo (1993), estudando a avifauna de 2 reservas da Mata Atlântica localizadas na Serra da Mantiqueira, obteve 78 e 81 espécies e H' = 3,6 e 3,8 respectivos. Allegrini (1997), estudando a avifauna em diferentes estágios de regeneração na Mata Atlântica da Serra de Paranapiacaba, obteve $\mathrm{H}^{\prime}=$ 3,68 para o estágio avançado, o mesmo $\mathrm{H}^{\prime}$ obtido no fragmento amarelo e próximo do $\mathrm{H}^{\prime}=3,77$ obtido no fragmento vermelho. No estágio médio, Allegrini (1997) obteve $\mathrm{H}^{\prime}=3,95$, muito próximo do $\mathrm{H}^{\prime}=3,98$ obtido no corredor que interliga os fragmentos. Tal fato se deve por esta área estar sofrendo maior efeito de borda, com maior número de espécies querendo colonizá-la. No estágio pioneiro, Allegrini (1997) obteve $\mathrm{H}^{\prime}=3,45$, também muito próximo do o $\mathrm{H}^{\prime}=3,44$ obtido no sub-bosque de eucalipto, demostrando que estes ambientes podem comportar o mesmo número de espécies. 
Machado (1996) obteve para toda a avifauna estudada na Estação Ecológica do Bracinho, de 1.331,94 hectares e localizada no Município de Joinville, Estado de Santa Catarina, $\mathrm{H}^{\prime}=4,08$, indicando uma riqueza expressiva da área. Este fato demonstra que o tamanho da área está diretamente relacionado com a diversidade de espécies.

A alta diversidade de aves nas florestas tropicais úmidas é atribuída à grande quantidade de guildas especializadas, as quais são encontradas somente nestes tipos de ambientes (Terborgh, 1992).

\subsubsection{7 Índice de eqüidade $(\mathrm{E})$}

Este índice nos permite conhecer o quanto de riqueza de espécies uma área pode abrigar, em função da abundância de espécies (Tabela 18).

A eqüidade adota um valor compreendido entre 0 e 1 . O valor é máximo (1), quando todas as espécies são igualmente abundantes, e aproxima-se de zero quanto menos equilibrada for a distribuição numérica das espécies (Allegrini, 1997).

Tabela 18. Índice de eqüidade (E) calculado para as áreas estudadas $(\mathrm{FV}=$ fragmento vermelho, $\mathrm{C}=$ corredor, $\mathrm{FA}=$ fragmento amarelo, $\mathrm{SB}=$ sub-bosque de eucalipto).

\begin{tabular}{cc}
\hline área & $\mathrm{E}$ \\
\hline FV & 0,84 \\
C & 0,90 \\
FA & 0,83 \\
SB & 0,92 \\
\hline
\end{tabular}

De acordo com a Tabela 18, o índice de equiidade variou de 0,83 a 0,92 da riqueza específica encontrada nas áreas estudadas. Apesar do sub-bosque de eucalipto apresentar uma diversidade de espécies inferior a das áreas com vegetação natural, as espécies observadas neste ambiente representam quase a capacidade máxima que a área pode abrigar. 
Provavelmente o $\mathrm{H}^{\prime}$ e o E do corredor foram maiores devido ao incremento do efeito de borda que é mais acentuado neste ambiente. O índice de eqüidade obtido por Machado (1996), $\mathrm{E}=0,88$, foi muito próximo do obtido no corredor $(\mathrm{E}=0,90)$.

\subsubsection{8 Índice de similaridade de Jaccard (J)}

Foi calculado o índice de similaridade de Jaccard para as áreas estudadas (Tabela 19). Este índice indica a semelhança, em porcentagem, em nível de espécies, entre duas ou mais comunidades.

Tabela 19. Índice de similaridade de Jaccard (J) calculado para as áreas estudadas (FV = fragmento vermelho, $\mathrm{C}=$ corredor, $\mathrm{FA}=$ fragmento amarelo, $\mathrm{SB}=$ subbosque de eucalipto).

\begin{tabular}{cc}
\hline área & $\mathrm{J}(\%)$ \\
\hline FV+C & 65,71 \\
FV+FA & 67,31 \\
C+FA & 66,34 \\
FV+SB & 41,93 \\
C+SB & 46,51 \\
FA+SB & 44,82 \\
\hline
\end{tabular}

O índice de similaridade calculado indica haver muita semelhança entre as 3 áreas de vegetação natural, quanto a avifauna presente. Tal fato é importante quando pensamos na efetividade do corredor no fluxo de aves entre os fragmentos.

Considerando-se apenas a avifauna, pode-se agrupar os 2 fragmentos e o corredor, formando um grupo que se diferencia do sub-bosque de eucalipto, constatando que existe uma barreira que impede que muitas espécies de aves que freqüentam os ambientes de vegetação natural, utilizem o sub-bosque de eucalipto.

Apesar do sub-bosque de eucalipto ter apresentado índice inferior em relação às áreas de vegetação natural, este ambiente demonstra funcionar efetivamente como hábitat para algumas espécies que vivem ou se deslocam entre a vegetação predominantemente arbustiva. Nota-se que o sub-bosque de eucalipto possui maior 
similaridade com o corredor do que com os fragmentos, pois o corredor está sofrendo maior efeito de borda, pela alta razão borda/interior, com muita pressão de espécies de ambientes abertos e antropisados.

\subsubsection{Método de captura e recaptura}

\subsubsection{Quantidade de indivíduos registrados}

Através do método de captura e recaptura foram realizadas 371 coletas (299 capturas e 72 recapturas) de aves distribuídas em 54 espécies de 14 famílias e 6 ordens, respectivamente $38,85 \%, 42,42 \%$ e $42,86 \%$ do total registrado por todos os métodos utilizados. O índice de indivíduos mortos foi de 2,96\% (11 indivíduos), ocasionado pelo excessivo estresse ao qual as aves capturadas estão sujeitas. A relação das espécies e o número de capturas e recapturas, de acordo com cada área estudada encontram-se nas Tabelas 20 e 21.

Tabela 20. Relação das espécies capturadas e recapturadas, com o número de recapturas entre parêntesis $(\mathrm{FV}=$ fragmento vermelho, $\mathrm{C}=$ corredor, $\mathrm{FA}=$ fragmento amarelo, SB = sub-bosque de eucalipto).

\begin{tabular}{lccccc}
\hline \multicolumn{1}{c}{ espécie } & FV & C & FA & SB & total \\
\hline Micrastur ruficollis & - & - & 1 & - & 1 \\
Leptotila verreauxi & - & - & 1 & - & 1 \\
Geotrygon montana & 1 & - & - & - & 1 \\
Phaethornis eurynome & $6(1)$ & $9(3)$ & 2 & - & $17(4)$ \\
Phaethornis pretrei & - & 1 & - & - & 1 \\
Stephanoxis lalandi & 1 & 1 & - & - & 2 \\
Thalurania glaucopis & - & 1 & - & - & 1 \\
Leucochloris albicollis & - & $2(1)$ & - & - & $2(1)$ \\
Amazilia fimbriata & - & - & 1 & - & 1 \\
Chloroceryle americana & - & 2 & $4(3)$ & - & $6(3)$ \\
Picumnus cirratus & 2 & - & - & - & 2 \\
Veniliornis spilogaster & - & - & - & 1 & 1 \\
Thamnophilus caerulescens & 2 & 2 & 1 & 5 & 10 \\
Dysithamnus mentalis & 1 & - & - & - & 1 \\
Pyriglena leucoptera & $10(1)$ & 2 & 2 & - & $14(1)$ \\
Conopophaga lineata & 4 & 3 & 5 & $2(1)$ & $14(1)$ \\
Synallaxis spixi & 1 & - & - & - & 1 \\
Synallaxis ruficapilla & 1 & 1 & - & 1 & 3 \\
\hline
\end{tabular}


Tabela 20. Relação das espécies capturadas e recapturadas, com o número de recapturas entre parêntesis $(\mathrm{FV}=$ fragmento vermelho, $\mathrm{C}=$ corredor, $\mathrm{FA}=$ fragmento amarelo, $\mathrm{SB}=$ sub-bosque de eucalipto).

\begin{tabular}{|c|c|c|c|c|c|}
\hline espécie & FV & $\mathrm{C}$ & FA & SB & total \\
\hline Synallaxis cinerascens & 1 & - & - & - & 1 \\
\hline Syndactyla rufosuperciliata & $6(1)$ & $5(3)$ & $4(1)$ & 1 & $16(5)$ \\
\hline Lochmias nematura & 3 & 2 & $10(4)$ & - & $15(4)$ \\
\hline Sittasomus griseicapillus & 6 & 4 & $4(2)$ & 1 & $15(2)$ \\
\hline Lepidocolaptes fuscus & $7(1)$ & $2(1)$ & $9(3)$ & 1 & $19(5)$ \\
\hline Elaenia flavogaster & & 1 & - & - & 1 \\
\hline Elaenia parvirostris & - & $7(1)$ & - & 1 & $8(1)$ \\
\hline Elaenia cristata & - & 1 & - & - & 1 \\
\hline Todirostrum plumbeiceps & $3(1)$ & - & - & - & $3(1)$ \\
\hline Tolmomyias sulphurescens & 1 & - & - & 1 & 2 \\
\hline Tolmomyias poliocephalus & $2(1)$ & - & - & - & $2(1)$ \\
\hline Platyrinchus mystaceus & 2 & $7(2)$ & $9(1)$ & $6(1)$ & $24(4)$ \\
\hline Myiobius barbatus & - & 1 & 3 & - & 4 \\
\hline Lathrotriccus euleri & - & 3 & 3 & - & 6 \\
\hline Attila rufus & 3 & 1 & 2 & - & 6 \\
\hline Pachyramphus polychopterus & 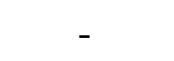 & 1 & $2(1)$ & 1 & $4(1)$ \\
\hline Chiroxiphia caudata & $10(2)$ & $5(1)$ & $8(2)$ & $5(1)$ & $28(6)$ \\
\hline Ilicura militaris & & 1 & - & - & 1 \\
\hline Platycichla flavipes & - & 1 & - & - & 1 \\
\hline Turdus rufiventris & $5(1)$ & $8(3)$ & $12(6)$ & - & $25(10)$ \\
\hline Turdus amaurochalinus & - & 4 & 1 & - & 5 \\
\hline Turdus albicollis & - & - & 2 & - & 2 \\
\hline Cyclarhis gujanensis & 1 & - & - & - & 1 \\
\hline Vireo olivaceus & 1 & 1 & 1 & - & 3 \\
\hline Hylophilus poicilotis & 1 & - & - & 1 & 2 \\
\hline Geothlypis aequinoctialis & 1 & - & - & - & 1 \\
\hline Basileuterus culicivorus & 5 & 1 & - & $5(2)$ & $11(2)$ \\
\hline Basileuterus leucoblepharus & $20(5)$ & $13(10)$ & $15(4)$ & 3 & $51(19)$ \\
\hline Tachyphonus coronatus & 3 & 5 & 3 & - & 11 \\
\hline Trichothraupis melanops & 2 & 4 & 1 & - & 7 \\
\hline Stephanophorus diadematus & - & 1 & - & - & 1 \\
\hline Pipraeidea melanonota & - & 2 & - & - & 2 \\
\hline Tangara desmaresti & - & 5 & - & - & 5 \\
\hline Zonotrichia capensis & 1 & - & - & - & 1 \\
\hline Haplospiza unicolor & - & 1 & 1 & - & 2 \\
\hline Saltator similis & 2 & $3(1)$ & - & - & $5(1)$ \\
\hline total & $115(14)$ & $114(26)$ & $107(27)$ & $35(5)$ & $371(72)$ \\
\hline
\end{tabular}


Tabela 21. Número de espécies, famílias e ordens registradas em cada área $(\mathrm{FV}=$ fragmento vermelho, $\mathrm{C}=$ corredor, $\mathrm{FA}=$ fragmento amarelo, $\mathrm{SB}=$ subbosque de eucalipto).

\begin{tabular}{cccc}
\hline área & $\mathrm{n}^{\mathrm{o}}$ espécies & $\mathrm{n}^{\mathbf{0}}$ famílias & $\mathrm{n}^{\mathbf{0}}$ ordens \\
\hline $\mathrm{FV}$ & 32 & 12 & 4 \\
$\mathrm{C}$ & 37 & 11 & 3 \\
$\mathrm{FA}$ & 26 & 13 & 5 \\
$\mathrm{SB}$ & 15 & 9 & 2 \\
\hline
\end{tabular}

Do total de espécies registradas através do método de captura e recaptura, $59,26 \%$ foram registradas no fragmento vermelho, $68,52 \%$ no corredor, $48,15 \%$ no fragmento amarelo e 27,78\% no sub-bosque. Destas, 37,04\% (20 espécies) são comuns ao fragmento vermelho e corredor; 40,74\% (22 espécies) são comuns ao corredor e fragmento amarelo; 29,63\% (16 espécies) são comuns aos 2 fragmentos e às 3 áreas de vegetação natural.

Das espécies registradas por este método, 18,52\% (10 espécies) são exclusivas do fragmento vermelho, 18,52\% (10 espécies) são exclusivas do corredor, $7,41 \%$ (4 espécies) são exclusivas do fragmento amarelo e 1,85\% (1 espécie) é exclusiva do sub-bosque.

É importante ressaltar que, através do método de captura e recaptura, houve o registro de 4 espécies que não foram registradas pelo método de observação por pontos fixos: Geotrygon montana, Synallaxis cinerascens, Tolmomyias poliocephalus e Haplospiza unicolor. Este fato reforça a idéia de Gonzaga (1986), de que devemos adotar uma combinação de métodos específicos de levantamentos de aves, procurando empregar métodos de captura, e de constatação visual e auditiva, para obtermos uma maior representatividade da área estudada.

O objetivo maior da utilização do método de captura e recaptura foi a possibilidade de se conhecer a movimentação dos indivíduos de diferentes espécies nas áreas estudadas. A captura, marcação e recaptura destes indivíduos permitiu que houvesse a constatação da utilização do corredor como passagem entre os fragmentos. 


\subsubsection{Esforço de captura}

Tabela 22. Esforço de captura para as áreas estudadas $(\mathrm{FV}=$ fragmento vermelho, $\mathrm{C}=$ corredor, $\mathrm{FA}=$ fragmento amarelo, $\mathrm{SB}=$ sub-bosque de eucalipto, $\mathrm{HR}=$ hora rede).

\begin{tabular}{cc}
\hline área & $\mathrm{n}^{\mathbf{o}}$ captura/HR \\
\hline $\mathrm{FV}$ & 0,14 \\
$\mathrm{C}$ & 0,18 \\
$\mathrm{FA}$ & 0,13 \\
$\mathrm{SB}$ & 0,15 \\
total & 0,15 \\
\hline
\end{tabular}

De acordo com o Tabela 22, o esforço médio de captura para as 4 áreas estudadas foi de 0,15 capturas a cada hora rede. Este índice foi calculado separadamente, resultando em 0,14 capturas a cada hora rede no fragmento vermelho, 0,18 capturas a cada hora rede no corredor, 0,13 capturas a cada hora rede no fragmento amarelo e 0,15 capturas a cada hora rede no sub-bosque.

\subsubsection{Curvas do número acumulado de espécies}

Na Figura 18 são apresentadas as curvas do número acumulado de espécies para as 4 áreas estudadas juntas, onde observa-se a estabilização das curvas, coincidindo com o período final do levantamento. Através do resultado, conclui-se que as horas utilizadas para o método de captura e recaptura foram suficientes para o registro da maior parte das espécies da avifauna existentes nas áreas estudadas, que poderiam ser capturadas. Dividindo o tempo utilizado para as capturas em 4 períodos, temos que no $1^{\circ}$ período houve o registro de $46,30 \%$ das espécies capturadas, no $2^{\circ}$ período $18,52 \%$, no $3^{-}$período $9,26 \%$ e no $4^{-}$período $25,92 \%$. Ao longo do ano, houve um acréscimo esperado no número de espécies observadas, influenciado principalmente pela variação climática, florescimento e frutificação de determinadas espécies vegetais e provável perturbação ocasionada pelas atividades florestais próximas da área de estudo. 
Figura 18. Curvas do número acumulado de espécies para as áreas estudadas $(\mathrm{FV}=$ fragmento vermelho, $\mathrm{C}=$ corredor, $\mathrm{FA}=$ fragmento amarelo, $\mathrm{SB}=$ subbosque de eucalipto).

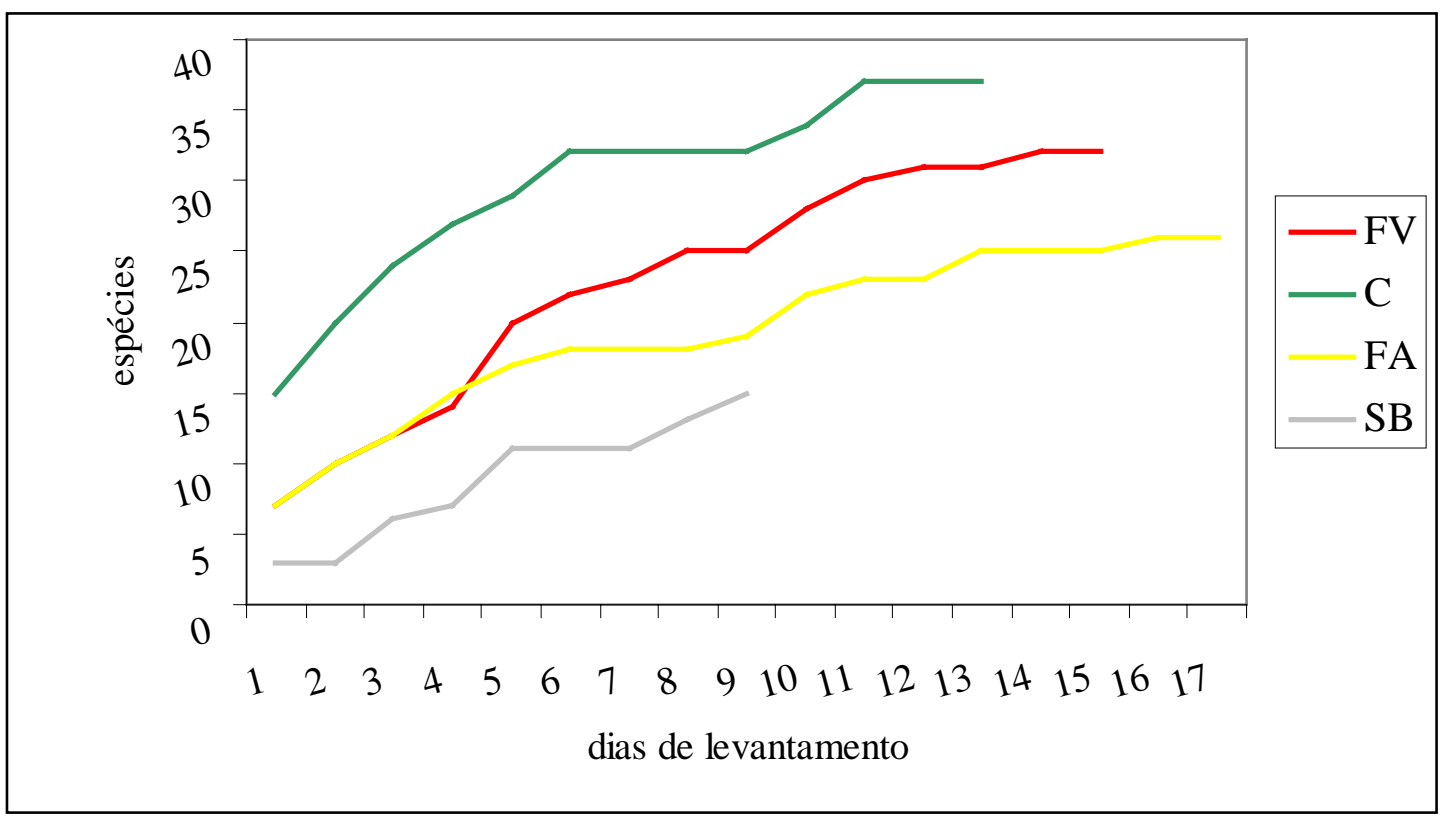

\subsubsection{Freqüência de captura (FC)}

Tabela 23. Freqüência de captura $(\mathrm{FC})$ calculada para as áreas de estudo $(\mathrm{FV}=$ fragmento vermelho, $\mathrm{C}=$ corredor, $\mathrm{FA}=$ fragmento amarelo, $\mathrm{SB}=$ subbosque de eucalipto).

\begin{tabular}{lccccc}
\hline \multicolumn{1}{c}{ espécie } & FV & C & FA & SB & total \\
\hline Micrastur ruficollis & - & - & 0,12 & - & 0,04 \\
Leptotila verreauxi & - & - & 0,12 & - & 0,04 \\
Geotrygon montana & 0,12 & - & - & - & 0,04 \\
Phaethornis eurynome & 0,75 & 0,62 & 0,24 & - & 0,44 \\
Phaethornis pretrei & - & 0,15 & - & - & 0,04 \\
Stephanoxis lalandi & 0,12 & 0,15 & - & - & 0,08 \\
Thalurania glaucopis & - & 0,15 & - & - & 0,04 \\
Leucochloris albicollis & - & 0,31 & - & - & 0,08 \\
Amazilia fimbriata & - & - & 0,12 & - & 0,04 \\
Chloroceryle americana & - & 0,31 & 0,36 & - & 0,20 \\
Picumnus cirratus & 0,12 & - & - & - & 0,04 \\
\hline
\end{tabular}


Tabela 23. Freqüência de captura $(\mathrm{FC})$ calculada para as áreas de estudo $(\mathrm{FV}=$ fragmento vermelho, $\mathrm{C}=$ corredor, $\mathrm{FA}=$ fragmento amarelo, $\mathrm{SB}=$ subbosque de eucalipto).

\begin{tabular}{lccccc}
\hline \multicolumn{1}{c}{ espécie } & FV & C & FA & SB & total \\
\hline Veniliornis spilogaster & - & - & - & 0,43 & 0,04 \\
Thamnophilus caerulescens & 0,25 & 0,31 & 0,12 & 1,28 & 0,32 \\
Dysithamnus mentalis & 0,12 & - & - & - & 0,04 \\
Pyriglena leucoptera & 0,87 & 0,31 & 0,24 & - & 0,36 \\
Conopophaga lineata & 0,37 & 0,47 & 0,48 & 0,86 & 0,32 \\
Synallaxis spixi & 0,12 & - & - & - & 0,04 \\
Synallaxis ruficapilla & 0,12 & 0,15 & - & 0,43 & 0,12 \\
Synallaxis cinerascens & 0,12 & - & - & - & 0,04 \\
Syndactyla rufosuperciliata & 0,50 & 0,62 & 0,36 & 0,43 & 0,36 \\
Lochmias nematura & 0,25 & 0,31 & 0,85 & - & 0,36 \\
Sittasomus griseicapillus & 0,50 & 0,47 & 0,48 & 0,43 & 0,36 \\
Lepidocolaptes fuscus & 0,75 & 0,31 & 0,97 & 0,43 & 0,48 \\
Elaenia flavogaster & - & 0,15 & - & - & 0,04 \\
Elaenia parvirostris & - & 0,47 & - & 0,43 & 0,12 \\
Elaenia cristata & - & 0,15 & - & - & 0,04 \\
Todirostrum plumbeiceps & 0,25 & - & - & - & 0,08 \\
Tolmomyias sulphurescens & 0,12 & - & - & 0,43 & 0,08 \\
Tolmomyias poliocephalus & 0,25 & - & - & - & 0,08 \\
Platyrinchus mystaceus & 0,25 & 0,62 & 0,73 & 0,86 & 0,44 \\
Myiobius barbatus & - & 0,15 & 0,24 & - & 0,08 \\
Lathrotriccus euleri & - & 0,47 & 0,12 & - & 0,16 \\
Attila rufus & 0,37 & 0,15 & 0,24 & - & 0,20 \\
Pachyramphus polychopterus & - & 0,15 & 0,24 & 0,43 & 0,12 \\
Chiroxiphia caudata & 0,75 & 0,62 & 0,85 & 2,14 & 0,52 \\
Ilicura militaris & - & 0,15 & - & - & 0,04 \\
Platycichla flavipes & - & 0,15 & - & - & 0,04 \\
Turdus rufiventris & 0,37 & 0,62 & 0,73 & - & 0,40 \\
Turdus amaurochalinus & - & 0,31 & 0,12 & - & 0,12 \\
Turdus albicollis & - & - & 0,12 & - & 0,04 \\
Cyclarhis gujanensis & 0,12 & - & - & - & 0,04 \\
Vireo olivaceus & 0,12 & 0,15 & 0,12 & - & 0,12 \\
Hylophilus poicilotis & 0,12 & - & - & 0,43 & 0,08 \\
Geothlypis aequinoctialis & 0,12 & - & - & - & 0,04 \\
Basileuterus culicivorus & 0,50 & 0,15 & 0,12 & 1,71 & 0,36 \\
Basileuterus leucoblepharus & 1,12 & 0,93 & 1,21 & 0,43 & 0,60 \\
Tachyphonus coronatus & 0,25 & 0,47 & 0,12 & - & 0,24 \\
Trichothraupis melanops & 0,12 & 0,31 & 0,12 & - & 0,12 \\
\hline
\end{tabular}


Tabela 23. Freqüência de captura (FC) calculada para as áreas de estudo $(\mathrm{FV}=$ fragmento vermelho, $\mathrm{C}=$ corredor, $\mathrm{FA}=$ fragmento amarelo, $\mathrm{SB}=$ subbosque de eucalipto).

\begin{tabular}{lccccc}
\hline \multicolumn{1}{c}{ espécie } & FV & C & FA & SB & total \\
\hline Stephanophorus diadematus & - & 0,15 & - & - & 0,04 \\
Pipraeidea melanonota & - & 0,15 & - & - & 0,04 \\
Tangara desmaresti & - & 0,31 & - & - & 0,08 \\
Zonotrichia capensis & 0,12 & - & - & - & 0,04 \\
Haplospiza unicolor & - & 0,15 & 0,12 & - & 0,08 \\
Saltator similis & 0,12 & 0,47 & - & - & 0,12 \\
\hline
\end{tabular}

No fragmento vermelho, Basileuterus leucoblepharus foi a espécie com a maior frequiência de captura, seguida da Pyriglena leucoptera, Phaethornis eurynome, Lepidocolaptes fuscus e Chiroxiphia caudata. Também no corredor a espécie Basileuterus leucoblepharus obteve a maior frequiência de captura, seguida da Chiroxiphia caudata e Phaethornis eurynome.

No fragmento amarelo, o Basileuterus leucoblepharus também obteve a maior frequiência de captura, seguido do Lepidocolaptes fuscus, Chiroxiphia caudata e Lochmias nematura. No sub-bosque de eucalipto, a maior freqüência de captura foi da espécie Chiroxiphia caudata, seguida do Basileuterus culicivorus e Thamnophilus caerulescens.

Observa-se que todas as espécies com maior freqüência de captura são típicas de sub-bosque, ambiente no qual a rede neblina é instalada. A espécie Pyriglena leucoptera, a $2^{\mathrm{a}}$ com maior freqüência de captura no fragmento vermelho, foi observada muitas vezes no piso da floresta, entre folhas e gravetos, se alimentando de formigas.

A espécie Lochmias nematura, a $4^{\mathrm{a}}$ com maior freqüência de captura no fragmento amarelo, foi observada constantemente entre folhas e gravetos, no piso da floresta, próximo ao córrego, e foi capturada principalmente nas redes instaladas próximas ao córrego existente, o mesmo acontecendo com Chloroceryle americana, espécie piscívora. 


\subsubsection{Freqüência de recaptura (FR)}

Através da frequiência de recaptura, pode-se observar quais as espécies que tiveram maior porcentagem de indivíduos recapturados. A recaptura foi muito importante também na constatação da circulação das aves dentro e entre fragmentos.

Tabela 24: Frequiência de recaptura (FR) calculada para as áreas de estudo (FV = fragmento vermelho, $\mathrm{C}=$ corredor, $\mathrm{FA}=$ fragmento amarelo, $\mathrm{SB}=$ subbosque de eucalipto).

\begin{tabular}{lccccc}
\hline \multicolumn{1}{c}{ espécie } & FV & C & FA & SB & total \\
\hline Phaethornis eurynome & 0,12 & 0,46 & - & - & 0,16 \\
Leucochloris albicollis & - & 0,15 & - & - & 0,04 \\
Chloroceryle americana & - & - & 0,36 & - & 0,12 \\
Pyriglena leucoptera & 0,12 & - & - & - & 0,04 \\
Conopophaga lineata & - & - & - & 0,43 & 0,04 \\
Syndactyla rufosuperciliata & 0,12 & 0,46 & 0,15 & - & 0,20 \\
Lochmias nematura & - & - & 0,48 & - & 0,16 \\
Sittasomus griseicapillus & - & - & 0,24 & - & 0,08 \\
Lepidocolaptes fuscus & 0,12 & 0,15 & 0,36 & - & 0,20 \\
Elaenia parvirostris & - & 0,15 & - & - & 0,04 \\
Todirostrum plumbeiceps & 0,12 & - & - & - & 0,04 \\
Tolmomyias poliocephalus & 0,12 & - & - & - & 0,04 \\
Platyrinchus mystaceus & - & 0,31 & 0,15 & 0,43 & 0,16 \\
Pachyramphus polychopterus & - & - & 0,15 & - & 0,04 \\
Chiroxiphia caudata & 0,25 & 0,15 & 0,24 & 0,43 & 0,24 \\
Turdus rufiventris & 0,12 & 0,46 & 0,73 & - & 0,40 \\
Basileuterus culicivorus & - & - & - & 0,86 & 0,08 \\
Basileuterus leucoblepharus & 0,62 & 1,55 & 0,48 & - & 0,76 \\
Saltator similis & - & 0,15 & - & - & 0,04 \\
\hline
\end{tabular}

No fragmento vermelho, Basileuterus leucoblepharus foi a espécie com a maior freqüência de recaptura, seguida da Chiroxiphia caudata. Também no corredor a espécie Basileuterus leucoblepharus obteve a maior freqüência de recaptura, seguida da Phaethornis eurynome, Syndactyla rufosuperciliata e Turdus rufiventris.

No fragmento amarelo, Turdus rufiventris foi a espécies que obteve a maior freqüência de recaptura, seguido do Basileuterus leucoblepharus e Lochmias nematura. No sub-bosque de eucalipto, a maior frequiência de recaptura foi da espécie Basileuterus culicivorus. 
Para a soma das 4 áreas, a espécie com maior freqüência de recaptura foi Basileuterus leucoblepharus, seguida do Turdus rufiventris e Chiroxiphia caudata. A porcentagem de indivíduos recapturados para o total das áreas foi de $19,41 \%$.

\subsection{Eficiência amostral dos métodos utilizados}

Dos métodos utilizados, o qualitativo permitiu o registro de um número maior de espécies, pois não estava condicionado a nenhuma área e horário, como o método de observações por pontos fixos, onde o observador permanece 20 minutos em cada ponto de observação, registrando somente os indivíduos observados neste período. O método de captura e recaptura com redes é o mais restritivo de todos, pelo fato de amostrar principalmente as aves do sub-bosque e do estrato herbáceo, pois são instaladas a $0,10 \mathrm{~m}$ do solo, atingindo $2,80 \mathrm{~m}$ de altura.

Pelo método qualitativo foram registradas 124 espécies $(91,85 \%$ da amostragem geral), pelo método de observações por pontos fixos 113 espécies $(83,70 \%)$ e por captura e recaptura 54 espécies $(40,00 \%)$.

Do total das espécies registradas, 4 foram exclusivas do método por

captura e recaptura, 7 exclusivas do método de observações por pontos fixos e 18 exclusivas do método qualitativo. Foi muito importante a combinação destes 3 métodos, que proporcionou o registro de 135 espécies de aves distribuídas em 33 famílias e 14 ordens.

Tabela 25. Eficiência amostral dos métodos utilizados no levantamento da avifauna.

\begin{tabular}{lccc}
\hline \multicolumn{1}{c}{ espécie } & qualitativo & ponto fixo & rede \\
\hline Crypturellus obsoletus & $\mathrm{x}$ & $\mathrm{x}$ & \\
Butorides striatus & $\mathrm{x}$ & & \\
Tigrisoma lineatum & $\mathrm{x}$ & & \\
Cathartes aura & $\mathrm{x}$ & & \\
Coragyps atratus & $\mathrm{x}$ & $\mathrm{x}$ & \\
Buteo albicaudatus & $\mathrm{x}$ & $\mathrm{x}$ & \\
Buteo brachyurus & $\mathrm{x}$ & $\mathrm{x}$ & \\
Rupornis magnirostris & $\mathrm{x}$ & $\mathrm{x}$ & \\
Herpetotheres cachinnans & $\mathrm{x}$ & $\mathrm{x}$ & \\
Micrastur ruficollis & $\mathrm{x}$ & $\mathrm{x}$ & $\mathrm{x}$ \\
Milvago chimachima & $\mathrm{x}$ & $\mathrm{x}$ & \\
\hline
\end{tabular}


Tabela 25. Eficiência amostral dos métodos utilizados no levantamento da avifauna.

\begin{tabular}{|c|c|c|c|}
\hline espécie & qualitativo & ponto fixo & rede \\
\hline Polyborus plancus & $\mathrm{x}$ & $\mathrm{x}$ & \\
\hline Penelope superciliaris & & $\mathrm{x}$ & \\
\hline Rallus nigricans & $\mathrm{X}$ & $\mathrm{x}$ & \\
\hline Porzana albicollis & $\mathrm{x}$ & & \\
\hline Cariama cristata & & $\mathrm{x}$ & \\
\hline Columba picazuro & $\mathrm{X}$ & $\mathrm{x}$ & \\
\hline Columbina talpacoti & $\mathrm{x}$ & $\mathrm{x}$ & \\
\hline Leptotila verreauxi & $\mathrm{x}$ & $\mathrm{x}$ & $\mathrm{x}$ \\
\hline Geotrygon montana & & & $\mathrm{x}$ \\
\hline Pionus maximiliani & $\mathrm{X}$ & $\mathrm{x}$ & \\
\hline Piaya cayana & $\mathrm{x}$ & $\mathrm{x}$ & \\
\hline Guira guira & $\mathrm{x}$ & $\mathrm{x}$ & \\
\hline Tapera naevia & $\mathrm{x}$ & & \\
\hline Tyto alba & $\mathrm{x}$ & & \\
\hline Otus choliba & $\mathrm{x}$ & & \\
\hline Speotyto cunicularia & $\mathrm{x}$ & & \\
\hline Nyctibius griseus & $\mathrm{x}$ & $\mathrm{X}$ & \\
\hline Nyctidromus albicollis & $\mathrm{x}$ & $\mathrm{x}$ & \\
\hline Hydropsalis brasiliana & $\mathrm{x}$ & & \\
\hline Streptoprocne zonaris & $\mathrm{x}$ & & \\
\hline Phaethornis eurynome & $\mathrm{x}$ & $\mathrm{X}$ & $\mathrm{X}$ \\
\hline Phaethornis squalidus & $\mathrm{x}$ & & \\
\hline Phaethornis pretrei & $\mathrm{x}$ & $\mathrm{x}$ & $\mathrm{x}$ \\
\hline Melanotrochilus fuscus & $\mathrm{x}$ & $\mathrm{x}$ & \\
\hline Stephanoxis lalandi & $\mathrm{x}$ & $\mathrm{X}$ & $\mathrm{X}$ \\
\hline Chlorostilbon aureoventris & $\mathrm{x}$ & & \\
\hline Thalurania glaucopis & $\mathrm{x}$ & $\mathrm{X}$ & $\mathrm{X}$ \\
\hline Leucochloris albicollis & $\mathrm{x}$ & $\mathrm{x}$ & $\mathrm{x}$ \\
\hline Amazilia versicolor & $\mathrm{x}$ & & \\
\hline Amazilia fimbriata & $\mathrm{x}$ & $\mathrm{X}$ & $X$ \\
\hline Aphantochroa cirrhochloris & $\mathrm{x}$ & $\mathrm{x}$ & \\
\hline Clytolaema rubricauda & $\mathrm{x}$ & & \\
\hline Chloroceryle americana & $\mathrm{x}$ & $\mathrm{x}$ & $\mathrm{x}$ \\
\hline Pteroglossus castanotis & $\mathrm{x}$ & & \\
\hline Picumnus cirratus & $\mathrm{x}$ & $\mathrm{x}$ & $\mathrm{x}$ \\
\hline Colaptes campestris & $\mathrm{x}$ & $\mathrm{x}$ & \\
\hline Colaptes melanochloros & $\mathrm{x}$ & $\mathrm{x}$ & \\
\hline Veniliornis spilogaster & $\mathrm{x}$ & $\mathrm{x}$ & $\mathrm{x}$ \\
\hline Veniliornis passerinus & $\mathrm{x}$ & $\mathrm{x}$ & \\
\hline Mackenziaena severa & $\mathrm{x}$ & $\mathrm{x}$ & \\
\hline Thamnophilus doliatus & $\mathrm{x}$ & $\mathrm{x}$ & \\
\hline Thamnophilus caerulescens & $\mathrm{x}$ & $\mathrm{x}$ & $\mathrm{X}$ \\
\hline
\end{tabular}


Tabela 25. Eficiência amostral dos métodos utilizados no levantamento da avifauna.

\begin{tabular}{|c|c|c|c|}
\hline espécie & qualitativo & ponto fixo & rede \\
\hline Dysithamnus mentalis & $\mathrm{x}$ & $\mathrm{x}$ & $\mathrm{X}$ \\
\hline Drymophila malura & $\mathrm{x}$ & $\mathrm{x}$ & \\
\hline Drymophila squamata & $\mathrm{x}$ & $\mathrm{x}$ & \\
\hline Pyriglena leucoptera & $\mathrm{x}$ & $\mathrm{x}$ & $\mathrm{X}$ \\
\hline Conopophaga lineata & $\mathrm{x}$ & $\mathrm{x}$ & $\mathrm{x}$ \\
\hline Synallaxis spixi & $\mathrm{x}$ & $\mathrm{x}$ & $\mathrm{x}$ \\
\hline Synallaxis ruficapilla & $\mathrm{x}$ & $\mathrm{x}$ & $\mathrm{x}$ \\
\hline Synallaxis cinerascens & & & $\mathrm{x}$ \\
\hline Phacellodomus rufifrons & $\mathrm{X}$ & $\mathrm{x}$ & \\
\hline Phacellodomus ferrugineigula & $\mathrm{x}$ & $\mathrm{x}$ & \\
\hline Syndactyla rufosuperciliata & $\mathrm{x}$ & $\mathrm{x}$ & $\mathrm{x}$ \\
\hline Lochmias nematura & $\mathrm{x}$ & $\mathrm{x}$ & $\mathrm{x}$ \\
\hline Sittasomus griseicapillus & $\mathrm{x}$ & $\mathrm{x}$ & $\mathrm{x}$ \\
\hline Lepidocolaptes fuscus & $\mathrm{x}$ & $\mathrm{x}$ & $\mathrm{x}$ \\
\hline Camptostoma obsoletum & $\mathrm{x}$ & $\mathrm{x}$ & \\
\hline Elaenia flavogaster & $\mathrm{x}$ & $\mathrm{x}$ & $\mathrm{X}$ \\
\hline Elaenia parvirostris & $\mathrm{x}$ & $\mathrm{x}$ & $\mathrm{x}$ \\
\hline Elaenia cristata & $\mathrm{x}$ & $\mathrm{x}$ & $\mathrm{x}$ \\
\hline Elaenia obscura & & $\mathrm{x}$ & \\
\hline Serpophaga subcristata & & $\mathrm{x}$ & \\
\hline Mionectes rufiventris & $\mathrm{x}$ & $\mathrm{x}$ & \\
\hline Leptopogon amaurocephalus & $\mathrm{x}$ & $\mathrm{x}$ & \\
\hline Phylloscartes paulistus & $\mathrm{x}$ & $\mathrm{x}$ & \\
\hline Capsiempis flaveola & $\mathrm{x}$ & $\mathrm{x}$ & \\
\hline Myiornis auricularis & & $\mathrm{x}$ & \\
\hline Todirostrum poliocephalum & $\mathrm{x}$ & $\mathrm{x}$ & \\
\hline Todirostrum cinereum & $\mathrm{x}$ & $\mathrm{x}$ & \\
\hline Todirostrum plumbeiceps & $\mathrm{x}$ & $\mathrm{x}$ & $\mathrm{x}$ \\
\hline Tolmomyias sulphurescens & $\mathrm{x}$ & $\mathrm{x}$ & $\mathrm{x}$ \\
\hline Tolmomyias poliocephalus & & & $\mathrm{x}$ \\
\hline Platyrinchus mystaceus & $\mathrm{X}$ & $\mathrm{X}$ & $\mathrm{x}$ \\
\hline Myiobius barbatus & $\mathrm{x}$ & $\mathrm{x}$ & $\mathrm{x}$ \\
\hline Myiophobus fasciatus & $\mathrm{x}$ & $\mathrm{x}$ & \\
\hline Lathrotriccus euleri & $\mathrm{x}$ & $\mathrm{x}$ & $\mathrm{x}$ \\
\hline Knipolegus lophotes & $\mathrm{x}$ & $\mathrm{x}$ & \\
\hline Knipolegus cyanirostris & $\mathrm{x}$ & $\mathrm{x}$ & \\
\hline Attila rufus & $\mathrm{x}$ & $\mathrm{x}$ & $\mathrm{X}$ \\
\hline Myiarchus ferox & $\mathrm{x}$ & $\mathrm{x}$ & \\
\hline Pitangus sulphuratus & $\mathrm{x}$ & $\mathrm{x}$ & \\
\hline Myiozetetes similis & $\mathrm{x}$ & $\mathrm{x}$ & \\
\hline Empidonomus varius & $\mathrm{x}$ & $\mathrm{x}$ & \\
\hline Tyrannus savana & $\mathrm{x}$ & $\mathrm{x}$ & \\
\hline
\end{tabular}


Tabela 25. Eficiência amostral dos métodos utilizados no levantamento da avifauna.

\begin{tabular}{|c|c|c|c|}
\hline espécie & qualitativo & ponto fixo & rede \\
\hline Tyrannus melancholicus & $\mathrm{x}$ & $\mathrm{x}$ & \\
\hline Pachyramphus polychopterus & $\mathrm{x}$ & $\mathrm{x}$ & $\mathrm{X}$ \\
\hline Chiroxiphia caudata & $\mathrm{x}$ & $\mathrm{x}$ & $\mathrm{x}$ \\
\hline Ilicura militaris & $\mathrm{x}$ & $\mathrm{x}$ & $\mathrm{x}$ \\
\hline Notiochelidon cyanoleuca & $\mathrm{x}$ & & \\
\hline Stelgidopteryx ruficollis & $\mathrm{x}$ & & \\
\hline Cyanocorax cristatellus & $\mathrm{x}$ & $\mathrm{x}$ & \\
\hline Troglodytes aedon & $\mathrm{x}$ & $\mathrm{x}$ & \\
\hline Platycichla flavipes & $\mathrm{x}$ & $\mathrm{x}$ & $\mathrm{X}$ \\
\hline Turdus rufiventris & $\mathrm{x}$ & $\mathrm{x}$ & $\mathrm{x}$ \\
\hline Turdus amaurochalinus & $\mathrm{x}$ & $\mathrm{x}$ & $\mathrm{x}$ \\
\hline Turdus albicollis & $\mathrm{x}$ & $\mathrm{x}$ & $\mathrm{x}$ \\
\hline Cyclarhis gujanensis & $\mathrm{x}$ & $\mathrm{x}$ & $\mathrm{x}$ \\
\hline Vireo olivaceus & $\mathrm{x}$ & $\mathrm{x}$ & $\mathrm{x}$ \\
\hline Hylophilus poicilotis & $\mathrm{x}$ & $\mathrm{x}$ & $\mathrm{x}$ \\
\hline Hylophilus thoracicus & & $\mathrm{x}$ & \\
\hline Parula pitiayumi & $\mathrm{x}$ & $\mathrm{x}$ & \\
\hline Geothlypis aequinoctialis & $\mathrm{x}$ & $\mathrm{x}$ & $\mathrm{X}$ \\
\hline Basileuterus culicivorus & $\mathrm{x}$ & $\mathrm{x}$ & $\mathrm{x}$ \\
\hline Basileuterus leucoblepharus & $\mathrm{x}$ & $\mathrm{x}$ & $\mathrm{x}$ \\
\hline Coereba flaveola & $\mathrm{x}$ & $\mathrm{x}$ & \\
\hline Thlypopsis sordida & $\mathrm{x}$ & & \\
\hline Hemithraupis ruficapilla & $\mathrm{x}$ & $\mathrm{x}$ & \\
\hline Tachyphonus coronatus & $\mathrm{x}$ & $\mathrm{x}$ & $\mathrm{X}$ \\
\hline Trichothraupis melanops & $\mathrm{x}$ & $\mathrm{x}$ & $\mathrm{x}$ \\
\hline Thraupis sayaca & $\mathrm{x}$ & $\mathrm{x}$ & \\
\hline Stephanophorus diadematus & $\mathrm{x}$ & $\mathrm{x}$ & $\mathrm{X}$ \\
\hline Pipraeidea melanonota & $\mathrm{x}$ & $\mathrm{x}$ & $\mathrm{x}$ \\
\hline Euphonia chlorotica & $\mathrm{x}$ & $\mathrm{x}$ & \\
\hline Tangara desmaresti & $\mathrm{x}$ & $\mathrm{x}$ & $X$ \\
\hline Tangara cayana & & $\mathrm{x}$ & \\
\hline Dacnis cayana & $\mathrm{x}$ & $\mathrm{x}$ & \\
\hline Conirostrum speciosum & $\mathrm{x}$ & $\mathrm{x}$ & \\
\hline Zonotrichia capensis & $\mathrm{x}$ & $\mathrm{x}$ & $\mathrm{X}$ \\
\hline Haplospiza unicolor & & & $\mathrm{x}$ \\
\hline Volatinia jacarina & $\mathrm{x}$ & $\mathrm{X}$ & \\
\hline Sporophila caerulescens & $\mathrm{x}$ & $\mathrm{x}$ & \\
\hline Arremon flavirostris & $\mathrm{x}$ & $\mathrm{x}$ & \\
\hline Saltator similis & $\mathrm{x}$ & $\mathrm{x}$ & $\mathrm{x}$ \\
\hline Carduelis magellanicus & $\mathrm{x}$ & $\mathrm{x}$ & \\
\hline
\end{tabular}




\subsection{Efetividade do corredor}

Para verificar a efetividade do corredor, no fluxo de aves entre os fragmentos interligados, analisou-se a movimentação destas aves nos ambientes estudados, principalmente as 72 recapturas realizadas em diferentes áreas. A efetividade do corredor seria comprovada com a recaptura sendo realizada em área diferente da captura. No entanto, houve 5 recapturas em áreas diferentes das quais haviam sido realizadas as capturas (Tabela 26).

Tabela 26. Lista das aves recapturadas em áreas diferentes da captura (FV = fragmento vermelho, $\mathrm{C}=$ corredor, $\mathrm{FA}=$ fragmento amarelo, $\mathrm{SB}=$ sub-bosque de eucalipto).

\begin{tabular}{lcccccc}
\hline \multicolumn{1}{c}{ espécie } & captura & área & recaptura & área & recaptura & área \\
\hline Phaethornis eurynome & $09 / 02 / 97$ & FV & $10 / 02 / 97$ & C & - & - \\
Chiroxiphia caudata (fêmea) & $12 / 02 / 97$ & SB & $13 / 02 / 97$ & SB & $14 / 02 / 97$ & C \\
Chloroceryle americana (fêmea) & $13 / 02 / 97$ & C & $05 / 07 / 97$ & FA & - & - \\
Chiroxiphia caudata (macho) & $08 / 07 / 97$ & SB & $28 / 09 / 97$ & FV & - & - \\
Chiroxiphia caudata (macho) & $18 / 10 / 97$ & C & $15 / 11 / 97$ & FA & $16 / 11 / 97$ & FA \\
\hline
\end{tabular}

Apesar de algumas aves terem sido capturadas e recapturadas em áreas diferentes, pertencem a espécies que transitam em ambientes abertos, ficando difícil de afirmar que alguma destas tenham utilizado o corredor no trajeto.

A espécie Chiroxiphia caudata foi a $3^{\mathrm{a}}$ com maior IPA para o conjunto das áreas, ocorrendo em todos os ambientes estudados, inclusive no sub-bosque de eucalipto. Para esta e outras espécies, o plantio de eucalipto não se constitui numa barreira, permitindo a sua utilização no trajeto para que atinjam outras áreas e aumentando, desta forma, a porosidade do corredor de vegetação natural.

Um fato importante é que os plantios de eucaliptos existentes no entorno dos fragmentos e corredor se encontravam em diferentes idades, havendo portanto, uma variação quanto a densidade da vegetação e riqueza do sub-bosque, fato que deve influenciar na dinâmica das populações presentes nos ambientes vizinhos.

A efetividade do corredor seria confirmada com a passagem de espécies florestais entre os fragmentos interligados, principalmente as espécies que ocupam o 
sub-bosque das florestas, o que não foi constatado através dos levantamentos, nem mesmo um número maior de espécies mais adaptadas a tensão ecológica e as pressões antrópicas.

O fato de não ter havido a constatação da passagem de espécies florestais entre fragmentos, utilizando-se do corredor, não inviabiliza a hipótese de que esteja havendo troca de material genético entre estes ambientes, pois ambos são bastante semelhantes quanto a riqueza florística e faunística. 


\section{CONCLUSÕES}

Não houve a constatação da passagem pelo corredor, de nenhum indivíduo da avifauna tipicamente florestal. No entanto, o registro de uma grande quantidade de espécies comuns nas áreas de vegetação natural estudadas é importante, pois poderá estar havendo troca de material genético entre as populações.

A largura do corredor está diretamente ligada a sua efetividade, no entanto, a largura ideal é uma medida empírica, existindo outros fatores que podem influenciar na sua utilização pela fauna, como a área, composição e estrutura da vegetação, vizinhança, efeito de borda, pressões antrópicas, tensão de agentes externos, como fogo, inseticidas e espécies invasoras, biologia, ecologia e dinâmica das populações do corredor e dos fragmentos interligados.

Com a fragmentação dos ambientes naturais, algumas espécies da avifauna, principalmente as mais adaptadas às pressões antrópicas, passaram a utilizar o corredor, assim como o sub-bosque de eucalipto, havendo o aumento em densidade das espécies adaptadas aos ambientes antrópicos, assim como o aparecimento de novas espécies.

A grande diversidade de espécies da avifauna existente no corredor, distribuídas em diferentes grupos tróficos, demostra que o mesmo está funcionando como uma efetiva área de hábitat, complementando a cadeia de reserva existente, fato que dificulta o fluxo de algumas espécies pela competição por alimento e abrigo.

$\mathrm{O}$ registro de 135 espécies de aves de diferentes guildas alimentares e ocupando diferentes estratos da vegetação, com 6 espécies endêmicas e 1 ameaçada de extinção, demonstra a grande diversidade destes ambientes, embora fragmentados e sofrendo intensa ação antrópica, o que ressalta a importância da sua conservação. 
A fragmentação destes ambientes naturais pode ter eliminado hábitats reprodutivos de diversas espécies endêmicas e ameaçadas de extinção. Com a destruição destes hábitats, algumas espécies e situações evolutivas importantes podem ter sido eliminadas, causando o desequilíbrio nos ecossistemas envolvidos.

Apesar do grande número de espécies registradas, a redução e fragmentação dos ambientes naturais afetaram a dinâmica das populações das plantas e animais existentes, diminuindo o número de espécies e eliminando praticamente toda a fauna umbrófila, que é pouco tolerante às variações de temperatura e umidade.

Os plantios de eucalipto, mesmo com o sub-bosque bastante desenvolvido, constituem-se numa barreira para as espécies da avifauna, principalmente as florestais, mas podem funcionar como corredores para algumas espécies mais adaptadas às pressões antrópicas, aumentando desta forma, a porosidade dos fragmentos e dos corredores de vegetação natural.

A diversidade da vegetação e o número de estratos definidos estão diretamente ligados à diversidade e densidade da fauna. A distribuição, diversidade $\mathrm{e}$ densidade das plantas produtoras de frutos para a fauna determinam a diversidade, densidade e freqüência, principalmente das espécies frugívoras e onívoras.

Os corredores de vegetação natural ligando fragmentos devem ser utilizados como uma estratégia para mitigar os efeitos da fragmentação e das pressões antrópicas, independente da sua dimensão, mesmo não sendo efetivos para a maioria das espécies.

Há necessidade de se realizarem estudos complementares testando diferentes larguras de corredores, analisando-se a influência da vizinhança no grau de perturbação dos fragmentos e na efetividade do corredor, assim como estudos sobre populações mínimas viáveis, pois a fragmentação causa a redução de algumas populações, aumentando os problemas de consangüinidade e ocasionando extinções regionais. 
ANEXOS 
Anexo 01. Ficha de campo.

Idade: A (adulto); J (jovem); D (desconhecida)

Sexo: M (macho); F (fêmea); I (indeterminado)

Município:

Data:

Abertura:

\begin{tabular}{|c|c|c|c|c|c|c|c|}
\hline $\mathrm{N}^{\mathbf{0}}$ & Nome & No anilha & Idade & Sexo & Rede & Malha & Observação \\
\hline 01 & & & & & & & \\
\hline 02 & & & & & & & \\
\hline $\mathbf{0 3}$ & & & & & & & \\
\hline 04 & & & & & & & \\
\hline 05 & & & & & & & \\
\hline 06 & & & & & & & \\
\hline 07 & & & & & & & \\
\hline 08 & & & & & & & \\
\hline 09 & & & & & & & \\
\hline 10 & & & & & & & \\
\hline 11 & & & & & & & \\
\hline 12 & & & & & & & \\
\hline 13 & & & & & & & \\
\hline 14 & & & & & & & \\
\hline 15 & & & & & & & \\
\hline 16 & & & & & & & \\
\hline 17 & & & & & & & \\
\hline 18 & & & & & & & \\
\hline 19 & & & & & & & \\
\hline 20 & & & & & & & \\
\hline 21 & & & & & & & \\
\hline 22 & & & & & & & \\
\hline 23 & & & & & & & \\
\hline 24 & & & & & & & \\
\hline 25 & & & & & & & \\
\hline 26 & & & & & & & \\
\hline 27 & & & & & & & \\
\hline 28 & & & & & & & \\
\hline 29 & & & & & & & \\
\hline 30 & & & & & & & \\
\hline
\end{tabular}

Ambiente:

Responsável:

Fechamento:

No ${ }^{0}$ redes: 
Anexo 2. Espécies da avifauna registradas na área de estudo e nomes comuns.

\begin{tabular}{|c|c|c|}
\hline família & espécie & nome comum \\
\hline Tinamidae & Crypturellus obsoletus & inhambu guaçu \\
\hline \multirow[t]{2}{*}{ Ardeidae } & Butorides striatus & socozinho \\
\hline & Tigrisoma lineatum & socó boi \\
\hline \multirow[t]{2}{*}{ Cathartidae } & Cathartes aura & urubu de cabeça vermelha \\
\hline & Coragyps atratus & urubu de cabeça preta \\
\hline \multirow[t]{3}{*}{ Accipitridae } & Buteo albicaudatus & gavião de rabo branco \\
\hline & Buteo brachyurus & gavião de cauda curta \\
\hline & Rupornis magnirostris & gavião carijó \\
\hline \multirow[t]{4}{*}{ Falconidae } & Herpetotheres cachinnans & acauã \\
\hline & Micrastur ruficollis & gavião caburé \\
\hline & Milvago chimachima & carrapateiro \\
\hline & Polyborus plancus & caracará \\
\hline Cracidae & Penelope superciliaris & jacupemba \\
\hline \multirow[t]{2}{*}{ Rallidae } & Rallus nigricans & saracura sanã \\
\hline & Porzana albicollis & sanã carijó \\
\hline Cariamidae & Cariama cristata & seriema \\
\hline \multirow[t]{4}{*}{ Columbidae } & Columba picazuro & asa branca \\
\hline & Columbina talpacoti & rolinha \\
\hline & Leptotila verreauxi & juriti \\
\hline & Geotrygon montana & pariri \\
\hline Psittacidae & Pionus maximiliani & maitaca verde \\
\hline \multirow[t]{3}{*}{ Cuculidae } & Piaya cayana & alma de gato \\
\hline & Guira guira & anu branco \\
\hline & Tapera naevia & saci \\
\hline Tytonidae & Tyto alba & suindara \\
\hline \multirow[t]{2}{*}{ Strigidae } & Otus choliba & corujinha do mato \\
\hline & Speotyto cunicularia & coruja buraqueira \\
\hline Nyctibiidae & Nyctibius griseus & urutau \\
\hline \multirow[t]{2}{*}{ Caprimulgidae } & Nyctidromus albicollis & curiango \\
\hline & Hydropsalis brasiliana & bacurau tesoura \\
\hline Apodidae & Streptoprocne zonaris & andorinhão de coleira \\
\hline \multirow[t]{12}{*}{ Trochilidae } & Phaethornis eurynome & rabo branco de garganta rajada \\
\hline & Phaethornis squalidus & rabo branco miúdo \\
\hline & Phaethornis pretrei & rabo branco de sobre amarelo \\
\hline & Melanotrochilus fuscus & beija flor preto e branco \\
\hline & Stephanoxis lalandi & beija flor de topete \\
\hline & Chlorostilbon aureoventris & besourinho de bico vermelho \\
\hline & Thalurania glaucopis & tesoura de fronte violeta \\
\hline & Leucochloris albicollis & papo branco \\
\hline & Amazilia versicolor & beija flor de banda branca \\
\hline & Amazilia fimbriata & beija flor de garganta verde \\
\hline & Aphantochroa cirrhochloris & beija flor cinza \\
\hline & Clytolaema rubicauda & beija flor rubi \\
\hline Alcedinidae & Chloroceryle americana & martim pescador pequeno \\
\hline Ramphastidae & Pteroglossus castanotis & araçari castanho \\
\hline
\end{tabular}


Anexo 2. Espécies da avifauna registradas na área de estudo e nomes comuns.

\begin{tabular}{|c|c|c|}
\hline família & espécie & nome comum \\
\hline \multirow[t]{5}{*}{ Picidae } & Picumnus cirratus & pica pau anão barrado \\
\hline & Colaptes campestris & pica pau do campo \\
\hline & Colaptes melanochloros & pica pau verde barrado \\
\hline & Veniliornis spilogaster & pica pauzinho verde carijó \\
\hline & Veniliornis passerinus & pica pauzinho anão \\
\hline \multirow[t]{7}{*}{ Thamnophilidae } & Mackenziaena severa & borralhara \\
\hline & Thamnophilus doliatus & choca barrada \\
\hline & Thamnophilus caerulescens & choca da mata \\
\hline & Dysithamnus mentalis & choquinha lisa \\
\hline & Drymophila malura & choquinha carijó \\
\hline & Drymophila squamata & pintadinho \\
\hline & Pyriglena leucoptera & papa taoca do sul \\
\hline Conopophagidae & Conopophaga lineata & chupa dente \\
\hline \multirow[t]{7}{*}{ Furnariidae } & Synallaxis spixi & pichororé \\
\hline & Synallaxis ruficapilla & joão teneném \\
\hline & Synallaxis cinerascens & joão teneném da mata \\
\hline & Phacellodomus rufifrons & joão graveto \\
\hline & Phacellodomus erythrophthalmus & joão botina \\
\hline & Syndactyla rufosuperciliata & limpa folha quiete \\
\hline & Lochmias nematura & capitão da porcaria \\
\hline \multirow[t]{2}{*}{ Dendrocolaptidae } & Lepidocolaptes fuscus & arapaçu rajado \\
\hline & Sittasomus griseicapillus & arapaçu verde \\
\hline \multirow[t]{24}{*}{ Tyrannidae } & Camptostoma obsoletum & risadinha \\
\hline & Elaenia flavogaster & guaracava de barriga amarela \\
\hline & Elaenia parvirostris & guaracavaca de bico pequeno \\
\hline & Elaenia cristata & guaracava de topete uniforme \\
\hline & Elaenia obscura & maria tola \\
\hline & Serpophaga subcristata & alegrinho \\
\hline & Mionectes rufiventris & abre asa de cabeça cinza \\
\hline & Leptopogon amaurocephalus & cabeçudo \\
\hline & Phylloscartes paulistus & não pode parar \\
\hline & Capsiempis flaveola & marianinha amarela \\
\hline & Myiornis auricularis & miudinho \\
\hline & Todirostrum poliocephalum & teque teque \\
\hline & Todirostrum cinereum & relógio \\
\hline & Todirostrum plumbeiceps & ferreirinho de cara amarela \\
\hline & Tolmomyias sulphurescens & bico chato de orelha preta \\
\hline & Tolmomyias poliocephalus & bico chato de cabeça cinza \\
\hline & Platyrinchus mystaceus & patinho \\
\hline & Myobius barbatus & assanhadinho \\
\hline & Myiophobus fasciatus & filipe \\
\hline & Lathrotriccus euleri & enferrujado \\
\hline & Knipolegus lophotes & maria preta de penacho \\
\hline & Knipolegus cyanirostris & maria preta de bico azulado \\
\hline & Attila rufus & capitão de saíra \\
\hline & Myiarchus ferox & maria cavaleira \\
\hline
\end{tabular}


Anexo 2. Espécies da avifauna registradas na área de estudo e nomes comuns.

\begin{tabular}{|c|c|c|}
\hline família & espécie & nome comum \\
\hline \multirow[t]{6}{*}{ Tyrannidae } & Pitangus sulphuratus & bentevi \\
\hline & Myiozetetes similis & bentevizinho \\
\hline & Empidonomus varius & peitica \\
\hline & Tyrannus savana & tesoura \\
\hline & Tyrannus melancholicus & suiriri \\
\hline & Pachyramphus polychopterus & caneleiro preto \\
\hline \multirow[t]{2}{*}{ Pipridae } & Chiroxiphia caudata & tangará dançarino \\
\hline & Ilicura militaris & tangarazinho \\
\hline \multirow[t]{2}{*}{ Hirundinidae } & Notiochelidon cyanoleuca & andorinha pequena de casa \\
\hline & Stelgidopteryx ruficollis & andorinha serrador \\
\hline Corvidae & Cyanocorax cristatellus & gralha do campo \\
\hline Troglodytidae & Troglodytes aedon & corruíra \\
\hline \multirow{4}{*}{ Muscicapidae } & Platycichla flavipes & sabiá una \\
\hline & Turdus rufiventris & sabiá laranjeira \\
\hline & Turdus amaurochalinus & sabiá poca \\
\hline & Turdus albicollis & sabiá coleira \\
\hline \multirow[t]{4}{*}{ Vireonidae } & Cyclarhis gujanensis & gente de fora vem \\
\hline & Vireo olivaceus & juruviara \\
\hline & Hylophilus poicilotis & verdinho coroado \\
\hline & Hylophilus thoracicus & vite vite \\
\hline \multirow[t]{23}{*}{ Emberizidae } & Parula pitiayumi & mariquita \\
\hline & Geothlypis aequinoctialis & pia cobra \\
\hline & Basileuterus culicivorus & pula pula \\
\hline & Basileuterus leucoblepharus & pula pula assobiador \\
\hline & Coereba flaveola & sebinho \\
\hline & Thlypopsis sordida & canário sapé \\
\hline & Hemithraupis ruficapilla & saíra da mata \\
\hline & Tachyphonus coronatus & tiê preto \\
\hline & Trichothraupis melanops & tiê de topete \\
\hline & Thraupis sayaca & sanhaço cinzento \\
\hline & Stephanophorus diadematus & sanhaço frade \\
\hline & Pipraeidea melanonota & viúva \\
\hline & Euphonia chlorotica & vivi \\
\hline & Tangara desmaresti & saíra lagarta \\
\hline & Tangara cayana & saíra amarelo \\
\hline & Dacnis cayana & saí azul \\
\hline & Conirostrum speciosum & figuinha de rabo castanho \\
\hline & Zonotrichia capensis & tico tico \\
\hline & Haplospiza unicolor & cigarra bambu \\
\hline & Volatinia jacarina & tiziu \\
\hline & Sporophila caerulescens & papa capim \\
\hline & Arremon flavirostris & tico tico de bico amarelo \\
\hline & Saltator similis & trinca ferro \\
\hline Fringillidae & Carduelis magellanicus & pintassilgo \\
\hline
\end{tabular}


Anexo 3. Espécies da flora registradas na área de estudo e nomes comuns.

\begin{tabular}{|c|c|c|}
\hline família & espécie & nome comum \\
\hline Anacardiaceae & Schinus terebinthifolius Raddi & aroeira vermelha \\
\hline \multirow[t]{2}{*}{ Annonaceae } & Guatteria nigrescens Mart. & pindaíba preta \\
\hline & Rollinia dolabripetala (Raddi) St.Hil. & araticum do campo \\
\hline Apocynaceae & Aspidosperma parvifolium A.DC. & guatambu amarelo \\
\hline \multirow[t]{3}{*}{ Araceae } & Anthurium sp & antúrio \\
\hline & Philodendron $\mathrm{sp}_{1}$ & filodendro \\
\hline & Philodendron $\mathrm{sp}_{2}$ & filodendro \\
\hline \multirow[t]{2}{*}{ Arecaceae } & Bactris setosa Mart. & tucum bravo \\
\hline & Syagrus romanzoffianum Mart. & jerivá \\
\hline \multirow[t]{7}{*}{ Asteraceae } & Baccharis dracunculifolia DC. & alecrim \\
\hline & Bidens pilosa $\mathrm{L}$. & picão preto \\
\hline & Emilia sonchifolia DC. & falsa serralha \\
\hline & Mikania sp & cundurango \\
\hline & Piptocarpha axilaris Baker & vassoura preta \\
\hline & Vernonia polyanthes Less. & cambará guaçu \\
\hline & Vernonia puberula Less. & cambará branco \\
\hline \multirow[t]{4}{*}{ Bignoniaceae } & Arrabidea sp & cipó arrabidea \\
\hline & Jacaranda $\mathrm{sp}$ & caroba \\
\hline & Pyrostegia venusta Baill. & cipó de são joão \\
\hline & Tabebuia umbellata (Sond.) Sand. & ipê amarelo do brejo \\
\hline Boraginaceae & Cordia superba Cham. & babosa branca \\
\hline \multirow[t]{4}{*}{ Bromeliaceae } & Aechmea sp & caraguatá \\
\hline & Billbergia amoena (Lodd.) Lindl. & caraguatá \\
\hline & Tillandsia geminiflora Brogn. & barba de velho \\
\hline & Tillandsia carinata Wawra & barba de velho \\
\hline \multirow[t]{2}{*}{ Cactaceae } & Rhipsalis sp & bico de papagaio \\
\hline & Rhipsalis houlletiana Lem. & bico de papagaio \\
\hline \multirow[t]{2}{*}{ Caesalpiniaceae } & Bauhinia sp & unha de vaca \\
\hline & Copaifera langsdorffii Desf. & copaíba \\
\hline Cecropiaceae & Cecropia pachystachia Trec. & embaúba \\
\hline Chrysobalanaceae & Hirtella glaziovii Taub. & macucurana \\
\hline Clethraceae & Clethra scabra Pers. & carne de vaca \\
\hline Commelinaceae & Commelina virginica $\mathrm{L}$. & trapoeraba \\
\hline Convolvulaceae & Iротеа $\mathrm{sp}$ & corda de viola \\
\hline Elaeocarpaceae & Sloanea guianense (Aubl.) Benth. & carrapicho \\
\hline \multirow[t]{7}{*}{ Euphorbiaceae } & Alchornea glandulosa Poepp. \& Endl. & tapiá \\
\hline & Alchornea triplinervia (Spreng.) Muell.Arg. & tapiá \\
\hline & Croton floribundus Spreng. & capixingui \\
\hline & Euphorbia brasiliensis Lam. & erva de santa luzia \\
\hline & Mabea fistulifera Mart. & mamoninha do mato \\
\hline & Pera glabrata (Schott) Bail. & tamanqueira \\
\hline & Sebastiania serrata (Baill.) Muell.Arg. & patereviú \\
\hline \multirow[t]{2}{*}{ Fabaceae } & Machaerium aculeatum Raddi & bico de pato \\
\hline & Machaerium villosum Vog. & jacarandá paulista \\
\hline \multirow[t]{2}{*}{ Flacourtiaceae } & Casearia decandra Jacq. & pau espeto \\
\hline & Casearia sylvestris Sw. & guaçatonga \\
\hline
\end{tabular}


Anexo 3. Espécies da flora registradas na área de estudo e nomes comuns.

\begin{tabular}{|c|c|c|}
\hline família & espécie & nome comum \\
\hline \multirow[t]{2}{*}{ Gesneriaceae } & Nematanthus fritschii Hoehne & peixinho \\
\hline & Nematanthus sp & peixinho \\
\hline \multirow[t]{3}{*}{ Lauraceae } & Nectandra lanceolata Nees & canela amarela \\
\hline & Ocotea puberula (Reich.) Nees & canela pimenta \\
\hline & Ocotea pulchella Mart. & canelinha \\
\hline Malpighiaceae & Heteropterys sp & cipó preto \\
\hline Malvaceae & Sida cordifolia $\mathrm{L}$. & guanxuma \\
\hline \multirow[t]{5}{*}{ Melastomataceae } & Leandra acutiflora Cogn. & pixirica \\
\hline & Miconia lurida Cogn. & jacatirão \\
\hline & Miconia sellowiana Naud. & jacatirão \\
\hline & Miconia $\mathrm{sp}_{1}$ & jacatirão \\
\hline & Miconia $\mathrm{sp}_{2}$ & jacatirão \\
\hline \multirow[t]{2}{*}{ Meliaceae } & Cabralea canjerana (Vell.) Mart. & canjerana \\
\hline & Cedrela fissilis Vell. & cedro \\
\hline \multirow[t]{5}{*}{ Mimosaceae } & Anadenanthera colubrina (Vell.) Brenan & angico branco \\
\hline & Inga sessilis (Vell.) Mart. & ingá \\
\hline & Mimosa scabrella Benth. & bracatinga \\
\hline & Parapiptadenia rigida (Benth.) Brenan & angico vermelho \\
\hline & Piptadenia gonoacantha (Mart.) Macb. & pau jacaré \\
\hline Moraceae & Ficus sp & figueira \\
\hline Myrsinaceae & Rapanea ferruginea (Ruiz et Pav.) Mez. & capororoca \\
\hline \multirow[t]{7}{*}{ Myrtaceae } & Campomanesia guazumaefolia (Camb.) Berg. & sete capotes \\
\hline & Eugenia $\mathrm{sp}_{1}$ & pitanga \\
\hline & Eugenia $\mathrm{sp}_{2}$ & cambuci \\
\hline & Gomidesia affinis (Camb.) Legr. & cambucá \\
\hline & Gomidesia spectabilis (DC.) Berg. & jabuticaba \\
\hline & Marliera reitzii Legr. & cambucá \\
\hline & Myrcia sp & cambuí \\
\hline Nyctaginaceae & Guapira opposita (Vell.) Reitz. & carne de vaca \\
\hline \multirow[t]{5}{*}{ Orchidaceae } & Dichaea sp & orquídea \\
\hline & Epidendron elongatum Jacq. & orquídea \\
\hline & Epidendron ramosum Jacq. & orquídea \\
\hline & Epidendron rigidum Jacq. & orquídea \\
\hline & Oncidium flexuosum Sims & chuva de ouro \\
\hline Passifloraceae & Passiflora sp & maracujá do mato \\
\hline \multirow[t]{2}{*}{ Piperaceae } & Piper aduncum $\mathrm{L}$. & pimenteira \\
\hline & Piper arboreum Aubl. & pimenteira \\
\hline Poaceae & Setaria geniculata (Lam.) Beauv. & capim rabo de raposa \\
\hline Rosaceae & Rubus rosaefolius Smith & amora vermelha \\
\hline \multirow[t]{3}{*}{ Rubiaceae } & Alibertia concolor (Cham.) Schum. & marmelinho do campo \\
\hline & Amaioua guianensis Aubl. & comichão \\
\hline & Psychotria sessilis Vell. & folha miúda \\
\hline Rutaceae & Zanthoxylum rhoifolium Lam. & mamica de porca \\
\hline \multirow[t]{3}{*}{ Sapindaceae } & Matayba juglandifolia Radlk. & caxuá branco \\
\hline & Paullinia sp & cipó timbó \\
\hline & Serjania sp & cipó timbó \\
\hline
\end{tabular}


Anexo 3. Espécies da flora registradas na área de estudo e nomes comuns.

\begin{tabular}{lll}
\hline \multicolumn{1}{c}{ família } & \multicolumn{1}{c}{ espécie } & \multicolumn{1}{c}{ nome comum } \\
\hline Solanaceae & Solanum sp & cipó \\
& Solanum americanum Mill. & fumo bravo \\
& Capsicum flexuosum Sendt. & pimenta brava \\
Sterculiaceae & Walteria indica L. & açoita cavalo \\
Tiliaceae & Luehea grandiflora Mart. et Zucc. & candiúba \\
Ulmaceae & Trema micrantha (L.) Blume & tamanqueiro \\
Verbenaceae & Aegiphila sellowiana Cham. & pau de tucano \\
& Cytharexyllum myrianthum Cham. & cambará miúdo \\
& Lantana camara L. & lírio do brejo \\
\hline
\end{tabular}




\section{REFERÊNCIAS BIBLIOGRÁFICAS}

AB'SABER, A.N. A Serra do Mar e a Mata Atlântica em São Paulo. Boletim Paulista de Geografia, n.2, p.61-70, 1950.

AB'SABER, A.N. Domínio dos mares de morros no Brasil. Geomorfologia, n.2, p.1-9, 1966.

AB'SABER, A.N. Os domínios morfoclimáticos na América do Sul. Geomorfologia, n.52, p.1-21, 1977.

AB'SABER, A.N. A teoria dos refúgios: origem e significado. In: CONGRESSO NACIONAL SOBRE ESSÊNCIAS NATIVAS, 2., São Paulo, 1992. Anais. São Paulo: Instituto Florestal, 1992. v.4, p.29-33.

AGASSIZ, J.L.R. Viagem ao Brasil: 1865-1866. Trad. de João Etienne Filho. São Paulo: EDUSP, 1975. 323p.

ALHO, C.J.R.; PEREIRA, L.A. Padrões de distribuição de pequenos mamíferos em hábitats do cerrado. In: CONGRESSO BRASILEIRO DE ZOOLOGIA, 14., Juiz de Fora, 1987. Resumos. Juiz de Fora, 1987. p.184.

ALLEGRINI, M.F. Avifauna como possível indicador biológico dos estádios de regeneração da Mata Atlântica. São Paulo, 1997. 161p. Dissertação (Mestrado) Programa de Pós-graduação em Ciência Ambiental, Universidade de São Paulo.

ALMEIDA, A.F. Aspectos biológicos no controle de saúvas. IPEF, n.78, p1-7, 1979.

ALMEIDA, A.F. Avifauna de uma área desflorestada em Anhembi, Estado de São Paulo, Brasil. São Paulo, 1981. 272p. Tese (Doutorado) - Instituto de Biociências, Universidade de São Paulo. 
ALMEIDA, A.F. Análise das categorias de nichos tróficos das aves de matas ciliares em Anhembi, Estado de São Paulo. In: CONGRESSO NACIONAL SOBRE ESSÊNCIAS NATIVAS, Campos do Jordão, 1982. Anais. São Paulo: Instituto Florestal, 1982a. v.3, p.1787-1795.

ALMEIDA, A.F. O manejo de fauna silvestre no Brasil: atividades atuais e perspectivas futuras. In: CONGRESSO NACIONAL SOBRE ESSÊNCIAS NATIVAS, Campos do Jordão, 1982. Anais. São Paulo: Instituto Florestal, 1982b. v.3, p.1543-1550.

ALMEIDA, A.F. Importância do manejo de habitat na restauração de áreas protegidas. Boletim do Programa Cooperativo de Silvicultura de Espécies Nativas, n.7, p.1$2,1995$.

ALMEIDA, A.F.; DÁRIO, F.R. A importância da avifauna na manutenção dos ecossistemas. In: SIMPÓSIO SOBRE RECUPERAÇÃO DE ÁREAS ALTERADAS, Piracicaba, 1995. Resumos. Piracicaba: AEAP, 1995.

ALMEIDA, A.F.; ALVES, J.E.M. Aves observadas combatendo um foco de lepidópteros desfolhadores de eucalipto (Thyrinteina arnobia e Glena sp) em Aracruz, ES. Silvicultura, v.28, n.8, p.135-138, 1982a.

ALMEIDA, A.F.; ALVES, J.E.M. Controle integrado de saúvas na Aracruz Florestal. Aracruz: Aracruz Florestal, 1982b. 80p.

ALMEIDA, F.F.M. Fundamentos geológicos do relevo paulista. Boletim do Instituto de Geografia e Geologia, v.41, p.169-263, 1964.

ALMEIDA, F.F.M.; HASUI, Y.; NEVES, B.B.B. The upper precambrian of South America. Boletim do Instituto de Geologia, v.7, p.45-80, 1976.

ALVIM, P.T. Silvicultura e meio ambiente: fatos e crendices. Ilhéus: Fundação Paubrasil, 1994. 12p.

AMBUEL, B.; TEMPLE, S.A. Area-dependent changes in the bird communities and vegetation of southern Wisconsin forests. Ecology, v.64, p.1057-1068, 1983. 
ANDERSON, S.H. Habitat selection, succession, and bird community organization. In: ESTADOS UNIDOS. Department of Agriculture. Management of western forests and grasslands for nongame birds. Salt Lake City: Forest Service General Technical Report, 1980. p.13-26.

ANDRADE-LIMA, D. A vegetação: atlas nacional do Brasil. Rio de Janeiro: Instituto Brasileiro de Geografia e Estatística, 1966. 11p.

ANJOS, L. Riqueza e abundância de aves em "ilhas" de Floresta de Araucária. Curitiba, 1992. 161p. Tese (Doutorado) -Universidade Federal do Paraná.

APPELQUIST, H.; ASBIRK, S.; DRABAEK,I. Mercury monitoring: content of guillemot feathers over 150 years. Maritime Pollution Bulletin, v.16, p.244-248, 1984.

ARREDONDO, C.; LÓPEZ R., V.; PÉREZ B.,M.; ARCE A., I.; PRIEGO, A. Consideraciones sobre la interaccion flora avifauna en un perfil ornitologico en la Sierra del Rosario, Pinar del Rio. In: CONGRESO LATINOAMERICANO DE BOTÀNICA, 5., La Habana, 1990. Resumos. La Habana: Academia de Ciencias de Cuba, 1990. p.34.

AVÉ-LALlEMANT, R. Viagens pelas províncias de Santa Catarina, Paraná e São Paulo, 1859. Trad. de T. Cabral. Belo Horizonte: Itatiaia, 1980. 356p.

AZEVEDO, L.H. Tipos de vegetação: atlas do Brasil. Rio de Janeiro: Fundação Instituto Brasileiro de Geografia e Estatística, 1959. 58p.

BAILEY, J.A. Principles of wildlife management. New York: John Wiley, 1984. 383 p.

BARLÉU, G. História dos feitos recentemente praticados durante oito anos no Brasil. São Paulo: EDUSP, 1974. 409 p.

BARROSO, G.M. Sistemática de angiospermas do Brasil. São Paulo: EDUSP, 1978, v.1, 245p.

BAWA, K.S.; PERRY, D.P.; BEACH, J.H. Reproductive biology of tropical lowland rain forest trees. American Journal of Botany, v.72, n.3, p.331-343, 1985.

BECKING, J.H. The ultrastructure of the avian eggshell. Ibis, n.117, p.143-151, 1975. 
BECKWITH, S.L. Ecological succession on abandoned farm lands and its relationship to wildlife management. Ecological Monographs, n.24, p.349-376, 1954.

BEIER, P. Are wildlife corridors the right path? Science, n.270, p.1428-1430, 1995.

BERNDT, R.A. Influência da estrutura da vegetação sobre a avifauna em uma floresta alterada de Araucaria angustifolia e em reflorestamentos em Telêmaco Borba Paraná. Piracicaba, 1992. 221p. Dissertação (Mestrado) - Escola Superior de Agricultura "Luiz de Queiroz", Universidade de São Paulo.

BERNDT, R.A. Análise da avifauna em reflorestamentos e mata nativa, na Fazenda Monte Alegre, Paraná. In: CONGRESSO FLORESTAL PANAMERICANO, 1., Curitiba, 1993. Anais. São Paulo: SBS, 1993. v.1, p.8-10.

BIERREGAARD, R.O. Species composition and trophic organization of the understory bird community in a central amazonian terra firme forest. In: GENTRY, A. Four neotropical forest. New Haven: Yale University Press, 1990. p.217-236.

BLAKE, J.G.; KARR, J.R. Species composition of bird communities and the conservation benefit of large versus small forests. Biological Conservation, v.30, p.173-187, 1984.

BOCK, C.E.; LINCH, J.F. Breeding bird populations of burned and unburned conifer forest in Sierra Nevada. Condor, v.72, p.182-189, 1970.

BRASIL. Ministério da Agricultura Levantamento e reconhecimento dos solos do Estado de São Paulo: contribuição à Carta de Solos do Brasil. Rio de Janeiro: Boletim do Serviço Nacional de Pesquisas Agronômicas, 1960. 634p. (Boletim, 12).

BRUSSARD, P.F.; EHRLICH, P.R.; SINGER, M.C. Adult movements and population structure in Euphydras editha. Evolution, v.28, p.408-415, 1974.

BURLATSKI, F. Fundamentos da filosofia Marxista-Leninista. Moscou: Progresso, 1987. 391p.

BURMEISTER, H. Viagem ao Brasil através das províncias do Rio de Janeiro e Minas Gerais, visando especialmente a história natural dos distritos auridiamantíferos. Trad. de M. Salvaterra e H. Schoenfeldt. São Paulo: EDUSP, 1980. $372 \mathrm{p}$. 
CÂMARA, I.G.; MITTERMEIER, R.A. Genetic diversity, endemism and protected areas: a case study of the endangered primates of Brazil's Atlantic forest region. In: McNEELY; MILLER, K.R. National parks, conservation and development. Washington: Smithsonian Institution Press, 1984. p.575-580.

CAMPOS, C. Mapa florestal. Rio de Janeiro: Ministério da Agricultura, Indústria e Comércio, Serviço Geológico e Mineralógico do Brasil, 1912. 20p.

CASE, T.J.; CODY, M.L. Testing theories of island biogeography. American Scientist, v.75, p.402-411, 1987.

CODY, M.L. Competition and the structure of birds communities. Princeton: Princeton University Press, 1974. 318p.

COLE, B.J. Colonizing abilities, island size and number of species - area relationships. The American Naturalist, v.117, p.629-683, 1981.

COLLAR, N.J.; GONZAGA, L.P.; KRABBE, N.; MADROÑO NIETO, A.; NARANJO,

L.G.; PARKER, T.A.; WEGE, D.C. Threatened birds of the America. Cambridge: International Council for Bird Preservation, 1992.

COMPANHIA SUZANO DE PAPEL E CELULOSE. Valores de temperatura e precipitação atmosférica do Município de Paraibuna-SP no período de 1986 a 1996. Moji das Cruzes: Divisão de Recursos Naturais, 1997.

CORREAA, M.P. Dicionário das plantas úteis do Brasil e das exóticas cultivadas. Rio de Janeiro: Imprensa Nacional, 1984. 6v.

COTTAM, C. Use of marking animals for ecological studies: marking birds scientific purposes. Ecological Monographs, n.37, p.675-681, 1956.

COUTINHO, L.M. Contribuição ao conhecimento da ecologia da Mata Pluvial Tropical. Boletim da Faculdade de Filosofia, Ciências e Letras da USP, n.18, p.1-219, 1962.

CRACRAFT, J. History biogeography and patterns of differentation within the South American avifauna: areas of endemism. Ornithology Monographs, n.36, p.49-84, 1985. 
CRONQUIST, A. An integrated system of classification of flowering plants. New York: Columbia University Press, 1981. 1262p.

DANSEREAU, P. Biodiversidade, ecodiversidade, sócio-diversidade. In: CONGRESSO NACIONAL SOBRE ESSÊNCIAS NATIVAS, 2., São Paulo, 1992, Anais. São Paulo: Instituto Florestal, 1992. v.4, p.22-28.

DÁRIO, F.R. A dispersão de sementes pelas aves. Silvicultura, n.58, p.32-34, 1994.

DÁRIO, F.R.; MONTEIRO, J.B. Manejo sustentado da caixeta - Tabebuia cassinoides (Lam.) DC - no litoral norte do Estado de São Paulo. In: SIMPÓSIO INTERNACIONAL DE ESTUDOS AMBIENTAIS SOBRE ECOSSISTEMAS FLORESTAIS, 3., Porto Alegre, 1994. Resumos. Porto Alegre: Biosfera, 1994. p. 19-21.

DEAN, W. Deforestation in Southeastern Brazil. In: TUCKER, R.P.; RICHARDS, J.F. Global deforestation and the nineteenth-century economy. Durham: Duke Press Policy Studies, 1983. p.50-67.

DEAN, W. A floresta como fonte de energia na urbanização e na industrialização de São Paulo, 1900-1950. In: SEMINÁRIO NACIONAL DE HISTÓRIA E ENERGIA, 1., São Paulo, 1987. Anais. São Paulo, 1987. p.41-55.

DEAN, W. A Ferro e fogo: a história e a devastação da Mata Atlântica Brasileira. São Paulo: Companhia das Letras, 1996. 484p.

DENIS, F. Brésil. Paris: Firmin Didot Fréres, 1888. 434p.

DIAMOND, J.M. Biogeographic kinetics: estimation of relaxation times for avifaunas of South-west Pacific islands. Proceedings National Academy Sciences of the USA, v.69, p.3199-3203, 1972.

DIAMOND, J.M. Normal extinction of isolated population. In: NITECKI, M.H. Chicago: University of Chicago Press, 1984. p.191-246.

DIRCEU, J.; PALMEIRA, V. Abaixo a ditadura. Rio de Janeiro: Garamond, 1998. $193 \mathrm{p}$. 
DOWNES, S.J.; HANDASYDE, K.A.; ELGAR, M.A. The use of corridors by mammals in fragmented Australian eucalypt forests. Conservation Biology, n.11, p.718-726, 1997.

DUBS, B. Birds of Southwestern Brazil: catalogue and guide to the birds of the Pantanal of Mato Grosso and its border areas. Küsnacht: Betrona-Verlag, 1992. $164 p$.

DUESER, R.D.; BROWN, W.C. Ecological correlates of insular rodent diversity. Ecology, v.61, p.50-56, 1980.

DUNNING, J.T. South american birds: a photographic aid to identification. Newtown Square: Harrowood Books, 1987. 351p.

EISEN, E.J. Population size and selection intensity effects on long-term selection response in mice. Genetics, v.79, p.305-323, 1975.

EITEN, G. A vegetação do Estado de São Paulo. São Paulo: Instituto de Botânica, 1970. 147p. (Instituto de Botânica. Boletim, 7).

EITEN, G. 1992. Natural brazilian vegetation types and there causes. Boletim da Academia Brasileira de Ciências, v.64, p.35-65, 1992.

ELKINS, N. Weather and bird behaviour. Calton: T. \& A.D.Poyser, 1983.

ELLEMBERG, H. \& MUELLER-DOMBOIS, D. Tentative physionomic ecological classification of plant formations of the earth. Geobotanic Institute, v.37, p.21-25, 1966.

ELTON, C.S. The ecology of invasions by animals and plants. London: Methuen, 1958. 181p.

ENGLER, A. Syllabus der pflanzenfamilien. Berlin: Gebruder Borntraeger, v.2, 1889. 666p.

EHRLICH, P.R. The loss of diversity: causes and consequences. In: WILSON, E.O.

Biodiversity. Washington: National Academy Press, 1988. p.21-27.

EHRLICH, P.R.; EHRLICH, A. Extinction: the causes and consequences of the disappearance os species. New York: Random House, 1981. 305p. 
FAO. Plano de ação florestal tropical. Roma, 1989. 32p.

FELSENSTEIN, J. Inbreeding and variance effective number in populations with overlapping generations. Genetics, v.68, p.581-597, 1971.

FERRI, M.G. Vegetação brasileira. São Paulo: EDUSP, 1980. 157p.

FONTES, M.A.; FRANCO, G.A.D.C.; TOZZI, A.M.G.A.; LEITÃO FILHO, H.F. A vegetação da Mata Atlântica na Ilha Anchieta: diversidade, manejo e regeneração. São Paulo, 1992. 11p.

FORMAN, R.T.T.; GODRON, M. Landscape ecology. New York: John Wiley, 1986. $619 \mathrm{p}$.

FORMAN, R.T.T.; GALLI, A.E.; LECK, C.F. Forest size and avian diversity in New Jersey woodlots with some land use implications. Oecologia, n.26, p.1-8, 1976.

FRISCH, J.D. Aves brasileiras. São Paulo: Dalgas Ecoltec, 1981. 353 p.

FRY, D.M.; FEFER, S.I.; SILEO, L. Ingestion of plastic debris by Laysan albatrosses and wedge-tailed shearwaters in the Hawaiian Islands. Maritime Pollution Bulletin, n.18, p.339-343, 1987.

FULLER, R.J.; LANGSLOW, D.R. Estimating numbers of birds by point counts: how long should counts last? Bird Study, n.31, p.195-202, 1984.

FUndAÇÃO SOS MATA ATLÂNTICA. Dossiê Mata Atlântica. São Paulo, 1992. $107 \mathrm{p}$.

FURNESS, R.W.; GREENWOOD, J.J.D. Birds as monitors of environmental change. London: Chapman \& Hall, 1984. 355p.

FUTUYMA, D.J. Evolutionary biology. 2.ed. Sunderland: Sinauer Associates, 1992. $631 \mathrm{p}$.

GALLI, A.E.; LECK, C.F.; FORMAN, R.T.T. Avian distribution patterns in forest islands of different sizes in central. The Auk, n.93, p.356-364, 1976.

GARDNER, G. Travels in the interior of Brazil, principally through the northern provinces and the gold and diamond districts, during the years 1836/1841. London: Reeve, 1846. 562p. 
GIANNOTI, E.; LEITÃO FILHO, H.F.; CESAR, O; PAGANO, S.N. Fitossociologia da vegetação arbórea da Mata Atlântica numa área perturbada em Picinguaba, Estado de São Paulo. In: CONGRESSO BRASILEIRO DE ANÁLISE AMBIENTAL, Rio Claro, 1994. Anais. Rio Claro: UNESP, 1994. p. 198-199.

GIESEL, J.T. The relations between population structure and rate of inbreeding. Evolution, v.25, p.491-496, 1971.

GILBERTSON, M.; ELLIOTT, J.E.; PEAKALL, D.B. Seabirds as indicators of marine pollution. In: DIAMOND, A.W.; FILION, F. The value of birds. Cambridge: International Council for Bird Preservation, 1987. p.231-248.

GIPSIN, M.E.; SOULÉ, M.E. Minimum viable populations: processes of species extinction. In: SOULÉ, M.E. Conservation biology: the science of scarcity and diversity. Sunderland: Sinauer Associates, 1986. p.19-34.

GOERCK, J.M. Patterns of rarity in the birds of the Atlantic forest of Brazil. St. Louis:

Conservation Biology, v.11, p.112-118, 1997.

GOMEZ-POMPA, A.; WIECHERS, L. Regeneración de los ecossistemas tropicales y subtropicales. In: GOMEZ-POMPA, A.; AMO, R. Investigaciones sobre la regeneración de selvas altas en Veracruz, México. México: Continental, 1976. cap.2, p.1-130.

GONZAGA, L.P. Composição da avifauna em uma parcela de mata perturbada na baixada, em Majé, Estado do Rio de Janeiro, Brasil. Rio de Janeiro, 1986. 110p. Dissertação (Mestrado) -Universidade Federal do Rio de Janeiro.

GRANER, E.A.; GODOY JÚNIOR, C. Manual do cafeicultor. São Paulo: EDUSP, 1967. $320 \mathrm{p}$.

GRANTSAU, R. Os beija-flores do Brasil. Rio de Janeiro: Expressão e Cultura, 1989. $233 \mathrm{p}$.

GREENWOOD, P.J.; HARVEY, P.H. The natal and breeding dispersal of birds. Annual Review of Ecology Systematics, v.13, p.1-21, 1982. 
GUILLAUMON, J.R. Mudança do pólo econômico do Nordeste para o Sudeste, no Brasil, e a destruição da Floresta - Mata Atlântica. Revista do Instituto Florestal, v.1, n.2, p.13-41, 1989.

GUILlaUMON, J.R.; MARCONDES, M.A.P. Le Parque Estadual de Campos do Jordão et l'axe de development Rio-São Paulo. In: CONGRES FORESTIER MONDIAL, 8., Jakarta, 1978. Proceedings. Jakarta, 1978.

HAAS, C.A. Dispersal and use of corridors by birds in wooded patches on an agricultural landscape. Conservation Biology, v.9, p.845-854, 1995.

HAFFER, J. Avian zoogeography of the neotropical lowlands. In: BUCKLEY, P.A.; FOSTER, M.S.; MORTON, E.S.; RIDGELY, R.S.; BUCKLEY, F.G. Neotropical ornithology. 1974. p.113-146.

HALL, F.C. Western forest and avian management practices. In: ESTADOS UNIDOS. Department of Agriculture. Management of western forests and grasslands for nongame birds. Salt Lake City: Forest Service General Technical Report, 1980. p.27-37.

HANSON, H.C. Dictionary of ecology. Washington: Philosophical Library, 1962. $382 p$.

HARRIS, L.D. The fragmented forest: island biogeography theory and the preservation of biotic diversity. Chicago: University of Chicago Press, 1984. 229p.

HILL, C.J. Linear strips of rain forest vegetation as potential dispersal corridors for rain forest insects. Conservation Biology, v.9, p.1559-1566, 1995.

HOEHNE, F.C. Botânica e agricultura no Brasil no século XVI. São Paulo: Companhia Editora Nacional, 1937. 410p.

HOEHNE, F.C. O litoral do Brasil meridional. São Paulo: Instituto de Botânica, 1940.

HOEHNE, F.C. Relatório Anual do Departamento de Botânica do Estado: referente ao exercício de 1940. São Paulo: Instituto de Botânica, 1941. 108p.

HOEHNE, F.C. Relatório Anual do Departamento de Botânica do Estado: referente ao exercício de 1941. São Paulo: Instituto de Botânica, 1942. 136p. 
HOFFMANN, R. Brasil urgente: impactos ambientais. São Bernardo do Campo: Partido dos Trabalhadores, 1989. p.2-8: Modernização e miséria.

HÖFLING, E.; LENCIONI, F. Avifauna da floresta atlântica, região de Salesópolis, Estado de São Paulo. Revista Brasileira de Biologia, v.52, p.361-378, 1992.

HUDSON, R. Implications of a greenhouse climate for British birds. British Trust for Ornithology, 1990.

HUECK, K. Sobre a origem dos campos cerrados no Brasil e algumas novas observações no seu limite meridional. Revista Brasileira de Geografia, n.19, p.68$80,1957$.

HUECK, K.; SEIBERT, P. Florestas da América do Sul. Brasília: UnB, 1972.

HUMBOLDT, A. von; BONPLAND, A. Personal narrative of travels to the equinoctial regions of America during the years 1799-1804. London: G. Routledge, 1852. 3v.

INSTITUTO BRASILEIRO DE GEOGRAFIA E ESTATÍSTICA Mapa de vegetação do Brasil. Rio de Janeiro, 1988.

INSTITUTO BRASILEIRO DO MEIO AMBIENTE E RECURSOS NATURAIS RENOVÁVEIS Manual de anilhamento de aves. Brasília: IBAMA, Centro de Estudos de Migrações de Aves, 1981. 114p.

INSTITUTO DE PESQUISAS E ESTUDOS DA VIDA SILVESTRE Mapeamento, qualificações e tipologias das vegetações naturais e implantadas e estudo da distribuição, tamanhos, formas e coberturas das reservas naturais da Eucatex. Piracicaba: IPEVS, 1999. 113p.

INSTITUTO DE PESQUISAS TECNOLÓGICAS DO ESTADO DE SÃO PAULO Mapa Geomorfológico do Estado de São Paulo. São Paulo, 1981a. 2v. INSTITUTO DE PESQUISAS TECNOLÓGICAS DO ESTADO DE SÃO PAULO Mapa Geológico do Estado de São Paulo. São Paulo, 1981b. 2v.

JANSEN, D.H. The eternal external threat. In: SOULÉ, M.E. Conservation biology: the science of scarcity and diversity. Sinauer Associates, 1986. p.286-303. 
JARVIS, P.J. Environmental changes. In: FURNESS, R.W.; GREENWOOD, J.J.D. Birds as monitors of environmental change. London: Chapman \& Hall, 1984. p.42-85.

JESUS, R.M. Mata Atlântica de Linhares: aspectos florestais. In: SEMINÁRIO DESENVOLVIMENTO ECONÔMICO E IMPACTO AMBIENTAL EM ÁREA DO TRÓPICO ÚMIDO BRASILEIRO, Belém, 1986. Anais. Belém, 1986. p.3571.

JOLY, A.B. Botânica: introdução à taxonomia vegetal. 11.ed. São Paulo: Editora Nacional, 1993. 777p.

JOLY, C.A.; LEITÃO FILHO; H.F.; SILVA, S.M. O patrimônio florístico. In: CAMARA, I.G. Mata Atlântica. São Paulo: Fundação SOS Mata Atlântica, 1991. KARR, J.R. Surveying birds with mist nets. In: RALPH, C.J.; SCOTT, J.M. Estimating numbers of terrestrial birds. Santa Clara: Cooper Ornithological Society, 1981. p.62-66.

KENDEIGH, S.C. Measurement of bird population. Ecological Monographs, n.14, p.67-106, 1944.

KIM, A.C. Lianas da Mata Atlântica do Estado de São Paulo. Campinas, 1996. 211p. Dissertação (Mestrado) - Instituto de Biologia, Universidade Estadual de Campinas.

KIM, A.C.; LEITÃO FILHO, H.F. Espécies de lianas da Mata Atlântica do Estado de São Paulo. In: CONGRESSO NACIONAL DE BOTÂNICA, 46., Ribeirão Preto, 1995, Resumos. Ribeirão Preto: USP, 1995. p.124.

KIMURA, M. The neutral theory of molecular evolution. Cambridge: Cambridge University Press, 1983. 367p.

KLEIN, R.M. Estrutura, composição florística, dinamismo e manejo da Mata Atlântica (floresta ombrófila densa) do sul do Brasil. In: SIMPÓSIO SOBRE ECOSSISTEMAS DA COSTA SUL E SUDESTE BRASILEIRA: ESTRUTURA, FUNÇÃO E MANEJO, 2., Águas de Lindóia, 1990. Anais. São Paulo: Academia de Ciências do Estado de São Paulo, 1990. v.1, p.255-286. 
KUHLMANN, M. Observações gerais e contribuições ao estudo da flora e fitofisionomia do Brasil. São Paulo: Instituto de Botânica, 1942. 32p.

LABORDE D., J.; GUEVARA S., S. Dispersion de semillas por aves en pastizales tropicales de Los Tuxtlas, Mexico. In: CONGRESO LATINOAMERICANO DE BOTÀNICA, 5., La Habana, 1990. Resumos. La Habana: Academia de Ciencias de Cuba, 1990. p.29.

LEBRETON, P.; CHOISY, J.P. Incidences avifaunistiques des amenagements forestieres: substitutions Quercus/Pinus en milieu submediterraneen. Bulletin d'Ecologie, n.22, p.213-220, 1991.

LEITÃO FILHO, H.F. Aspectos taxonômicos das florestas do Estado de São Paulo. In: CONGRESSO NACIONAL SOBRE ESSÊNCIAS NATIVAS, Campos do Jordão, 1982. Anais. São Paulo: Instituto Florestal, 1982. v.1, p.197-206.

LEITÃO FILHO, H.F. Ecologia da Mata Atlântica em Cubatão. Campinas: UNICAMP, 1993. 184p.

LEITE, J.F. As reservas ecológicas do sudoeste paulista. In: CONGRESSO ESTADUAL DE MUNICÍPIOS, 23., Praia Grande, 1979. Resumos. Praia Grande, 1979. p.8.

LÉRY, J. Viagem à terra do Brasil. Trad. de S. Milliet. São Paulo: EDUSP, 1980. $303 \mathrm{p}$.

LEWIS, R. Parks: how big is big enough. Science, n.225, p.611-612, 1984.

LEWONTIN, R.C. The organism as the subject and object of evolution. Scientia, n.118, p.65-82, 1983.

LINDENMAYER, D.B. Wildlife corridors and the mitigation of logging impacts on fauna in wood-production forests in south-eastern Australia: a review. WildlifeResearch, n.21, p.323-340, 1994.

LINSDALE, J.M. A method of showing relative frequency of occurrence of birds. Condor, n.30, p.180-184, 1928.

LÖFGREN, A. Contribuição para a flora paulista. Região Campestre. Boletim da Comissão Geográfica e Geológica do Estado de São Paulo, n.5, 1890. 
LÖFGREN, A. Ensaio para uma distribuição dos vegetais nos diversos grupos florísticos do Estado de São Paulo. Boletim da Comissão Geográfica e Geológica do Estado de São Paulo, n.11, p.5-47, 1896.

LORENZI, H. Manual de identificação e controle de plantas daninhas: plantio direto e convencional. 2.ed. Nova Odessa: Plantarum, 1986. 220p.

LORENZI, H. Árvores brasileiras: manual de identificação e cultivo de plantas arbóreas nativas do Brasil. Nova Odessa: Plantarum, 1992. 352p.

LORENZI, H. Palmeiras no Brasil: nativas e exóticas. Nova Odessa: Plantarum, 1996. $303 p$.

LOVEJOY, T.E.; BIERREGAARD JR, R.O.; RYLANDS, A.B.; MALCOLM, J.R.; QUINTELA, C.E.; HARPER, L.H.; BROWN JR, K.S.; POWELL, G.V.N.; SCHUBART, H.O.R.; HAYS, M.B. Edge and other effects of isolation on Amazon forest fragments. In: SOULÉ, M.E. Conservation biology: the science of scarcity and diversity. Sunderland: Sinauer Associates Inc., 1986. p.257-285.

LYNCH, J.F.; WHIGHAM, D.F. Effects of forest fragmentation on breeding bird communities in Maryland, USA. Biological Conservation, n.28, p.287-324, 1984.

MacARTHUR, R.H. Environmental factors affecting bird species diversity. American Naturalist, v.98, n.903, p.387-397, 1964.

MacARTHUR, R.H. Geographical ecology: patterns in the distribution of species. New York: Harper \& Row, 1972. 269p.

MacARTHUR, L.B.; WHITMORE, R.C. Passerine community composition and diversity in man-altered environments. West Virginia Forestry Notes, n.7, p.1-12, 1979.

MacARTHUR, R.H.; WILSON, E.O. The theory of island biogeography. Princeton: Princeton University Press, 1967. 203p.

MACHADO, D.A. Estudo das populações de aves silvestres da região do salto do Piraí e uma proposta de conservação para a Estação Ecológica do Bracinho, Joinville, Santa Catarina. Piracicaba, 1996. 148p. Dissertação (Mestrado) - Escola Superior de Agricultura "Luiz de Queiroz", Universidade de São Paulo. 
MAGRO, T.C. Avaliação da qualidade de habitat faunístico pela análise de bordas. Viçosa, 1988. 95p. Dissertação (Mestrado) -Universidade Federal de Viçosa.

MOTTA JUNIOR, J.C. Estrutura trófica e composição das avifaunas de três habitats terrestres na região central do estado de São Paulo. Ararajuba, n.1, p.65-71, 1990.

MAGNANINI, A. A ação do homem na extinção das espécies selvagens. Vellozia, n.1, 1961.

MAGNANINI, A. Vegetação. In: INSTITUTO BRASILEIRO DE GEOGRAFIA E ESTATÍSTICA. Geografia do Brasil: grande região leste. Rio de Janeiro, 1965. v.4, p.141-176.

MANN, C.C.; PLUMMER, M.L. Are wildlife corridors the right path? Science, n.270, p.1.428-1.430, Dec. 1995.

MANTOVANI, W.; RODRIGUES, R.R.; ROSSI, L.; ROMANIUC-NETO, S.; CATHARINO, E.L.M.; CORDEIRO, I. A vegetação da Serra do Mar em Salesópolis, SP. In: SIMPÓSIO SOBRE ECOSSISTEMAS DA COSTA SUL E SUDESTE BRASILEIRA, 2., Águas de Lindóia, 1990. Anais. São Paulo: Academia de Ciências do Estado de São Paulo, 1990. v.1, p.348-384.

MARTIUS, K.F.P. von Flora Brasiliensis: enumeration plantarum in brasilia. Monachii: R. Oldenboug, 1840. 15v.

MARTIUS, K.F.P. von A fisionomia do reino vegetal no Brasil. Anuário Brasileiro de Economia Florestal, n.10, p.209-227, 1958.

MARUYAMA, T.; KIMURA, M. Genetic variability and effective population size when local extinction and recolonization of subpopulations are frequent. Proceedings of the National Academy Science of the USA, v.77, p.6.710$6.714,1980$.

MASON, D. Responses of Venezuelan understory birds to selective logging, enrichment strips, and vine cutting. Biotropica, v.28, n.3, p.296-309, 1996.

MATARAZZO-NEUBERGER, W.M. Guildas, organização e estrutura da comunidade: análise da avifauna da Represa Billings, São Paulo, 1994. 174p. Tese (Doutorado) - Instituto de Biociências, Universidade de São Paulo. 
MAY, R.M. Stability and complexity in model ecossystems. Princeton: Princeton University Press, 1973. 235p.

MITCHELL, M.H. Observations on birds of Southeastern Brazil. Toronto: University of Toronto Press, 1957. 258p.

MONBEIG, P. A divisão regional do estado de São Paulo. Anuário da Associação Geográfica Brasileira, n.1, p.19-30, 1949.

MORI, S.A.; BOOM, B.M. Botanical survey of the endangered moist forest of eastern Brazil. The New York Botanical Garden, p.11-31, 1981.

MORRISON, M.L. Bird population as indicators of environmental change. Current Ornithology, n.3, p.429-451, 1986.

MORTON, J.S.; HALFORD, D.K.; PARKER, D. A confinement device for the determination of whole-body radionuclide concentrations in live ducks. Health Physics, n.38, p.234-236, 1980.

NAKANO, H. Manejo de bacias hidrográficas na floresta de produção de água no Japão e problemática da bacia hidrográfica do Rio Paraíba. In: CONGRESSO NACIONAL SOBRE ESSÊNCIAS NATIVAS, Campos do Jordão, 1982. Anais. São Paulo: Instituto Florestal, 1982. v.1, p.160-177.

NARAYANYAN, N.; EAPEN, J. Gross and subcellular distribution of caesiun-137 in pigeon (Columba livia) tissuer with special reference to muscles. Journal of Radiation Research, v.12, p.51-55, 1971.

NAROSKY, T.; YZURIETA, D. Birds of Argentina and Uruguai: a field guide. Buenos Aires: Associación Ornitológica del Plata, 1989. 337p.

NEWMARK, W.D. Tropical forests fragmentation and the local extinction of understory birds in the Eastern Usambara Mountains, Tanzania. Conservation Biology, v.5, p.67-78, 1991.

NEWMARK, W.D. The role and design of wildlife corridors with examples from Tanzania. Ambio, n.22, p.500-504, 1993.

NOVAES, F.C. Aves de uma vegetação secundária na Foz do Amazonas. Boletim do Museu Emílio Goeldi, n.21, p.1-88, 1978. 
NOVAES, F.C. Observações sobre a avifauna do alto curso do rio Paru de Leste, Estado do Pará. Boletim do Museu Emílio Goeldi: série zoologia, n.100, p.1-58, 1980.

ODUM, E.P. Ecologia. Rio de Janeiro: Interamericana, 1985. 434p.

OGAWA, H.Y.; MOTA, I.S.; FAVRIN, L.J.B.; VALENTINO, R.A.L.; ANDRADE, W.J. Inventário florestal do Estado de São Paulo: cobertura vegetal natural de duas sub-regiões do Vale do Paraíba. In: CONGRESSO NACIONAL SOBRE ESSÊNCIAS NATIVAS, Campos do Jordão, 1982. Anais. São Paulo: Instituto Florestal, 1982. v.1, p.441-446.

ORIANS, G.H.; PAINE, R.T. Convergent evolution at the community level. In: FUTUYMA, D.J.; SLATKIN, M. Coevolution. Sinauer Associates, 1983. p.431458.

ORMEROD, S.J.; TYLER, S.J. Environmental pollutants in the eggs of Welsh dippers Cinclus cinclus: a potential monitor of organochlorine and mercury contamination in upland rivers. Bird Study, v.37, p.171-176, 1990.

OSSE, L. Lenha, carvão e carvoejamento. Brasil Florestal, v.2, p.32-80, 1971.

PARTIDO DOS TRABALHADORES Brasil urgente: impactos ambientais. São Bernardo do Campo: Editora FG, 1989. 24p. (Caderno Questão Agrária).

PELZELN, A. von. Zur ornithologie brasiliens: resultate von Johann Natterers reisen in den jahren 1817 bis 1835 . Wien: A.Pichler's Witwe, 1871.

PERLIN, J. História das florestas: a importância da madeira no desenvolvimento da civilização. Rio de Janeiro: Imago, 1992. 490p.

PINTO, V.N. O ouro brasileiro e o comércio anglo-português. São Paulo, 1979.

PRANDINI, F.L.; AVILA, I.G.; LEITE, C.A.G.; SANTOS, M.T.N. Uso e ocupação do solo no Alto Paraíba: contribuição ao conhecimento de sua evolução. In: CONGRESSO NACIONAL SOBRE ESSÊNCIAS NATIVAS, Campos do Jordão, 1982. Anais. São Paulo: Instituto Florestal, 1982. v.3, p.1929-1935.

PRESTON, F.W. The canomical distributions of commonness and rarity: part 2. Ecology Monographs, v.43, n.3, p.410-432, 1962. 
PROJETO RADAMBRASIL. Levantamento de Recursos Naturais. Rio de Janeiro, 1983. v.32: folha SF-23/24.

RAND, A.L. The origin of the land birds of Tristan da Cunha. Fieldiana Zoology, n.37, p.139-166, 1955.

RECHER, H.F. Impact of wildfire on the avifauna of Kings Park, Perth, Western Australia. Wildlife-Research, v.24, p.745-761, 1997.

REIS, M.S. Programa e ação política do Instituto Brasileiro de Desenvolvimento Florestal para essências nativas. In: CONGRESSO NACIONAL SOBRE ESSÊNCIAS NATIVAS, Campos do Jordão, 1982. Anais. São Paulo: Instituto Florestal, 1982. v.1, p.44-89.

REYNOLDS, C.M. The heronries census: 1972-77 population changes and a review. Bird Study, n.26, p.7-12, 1979.

RICH, A.C.; DOBKIN, D.S.; NILES, L.J. Defining forest fragmentation by corridor width: the influence of narrow forest-dividing corridors on forest-nesting birds in southern New Jersey. Conservation Biology, n.8, p.1109-1121, 1994.

RICHARDS, P.W. The tropical rain forest: an ecological study. Cambridge: University Press, 1952. $632 \mathrm{p}$.

RIZZINI, C.T. Nota prévia sobre a divisão fitogeográfica (florístico-sociológica) do Brasil. Revista Brasileira de Geografia, v.25, n.1, p.3-64, 1963.

ROBBINS, C.S. Census techniques for forest birds. In: WORKSHOP MANAGEMENT OF SOUTHERN FORESTS FOR NONGAME BIRDS, Atlanta, 1978. Proceedings. Asheville: USDA, Forest Service, 1978. v.14, p.142-163.

ROBBINS, C.S.; SAUER, J.R.; GREENBERG, R.S.; DROEGE, S. Population declines in North American birds that migrate to the neotropics. Proceedings of the National Academy Sciences of the USA, v.86, p.7658-7662, 1989.

ROLSTAD, J. Consequences of forest fragmentation for the dynamics of bird populations: conceptual issues and the evidence. Biological Journal of the Linnean Society, v.42, p.149-163, 1991. 
ROMARIZ, D.A. A vegetação. In: AZEVEDO, A. Brasil: a terra e o homem. Companhia Editora Nacional, 1968. v.1.

ROSS, H.H.; DECKER, G.C.; CUNNINGHAM, H.B. Adaptation and differentiation of temperate phylogenetic lines from tropical ancestors in Empoasca. Evolution, n.18, p.639-651, 1964.

RUSCHI, A. Lista atual das aves do Estado do Espírito Santo. Santa Teresa: Museu de Biologia Mello Leitão, 1967. 45p. (Museu de Biologia. Boletim, 28).

RUSCHI, A. Os beija-flores do Brasil: chaves artificiais e analíticas. São Paulo: Ríos, 1986. $187 \mathrm{p}$.

SAINT-HILAIRE, A. Voyage aux sources du Rio de S. Francisco et dans la Province de Goyaz. Paris: Arthur Bertrand, 1847. 2v.

SAINT-HILAIRE, A. Voyage dans les Provinces de Saint Paul et de Saint Cathérine. Paris: Arthur Bertrand, 1851. 2v.

SAMPAIO, A.J. Phytogeographia do Brasil. São Paulo: Companhia Editora Nacional, v.35, 1938.

SCHAUENSEE, R.M. The species of birds of South America and their distribution. Livingston: Academy of Natural Sciences, 1966. 577p.

SCHAUENSEE, R.M. A guide to the birds of South America. Edinburgh: Oliver \& Boyd, 1982. 498p.

SCHAUENSEE, R.M.; PHELPS Jr., W.R. Una guia de las aves de Venezuela. Princeton: Princeton University Press, 1978. 484p.

SCHIMPER, A.F.W. Plant-geography upon physiological basis. Trad. de W. R. Fischer. Oxford: Claredon Press, 1903. 839 p.

SCHWAGER, G. Einfluss der Waldbewirtschaftung auf die Vogelwelt. Schweizerische Zeitschrift fur Forstwesen, v.135, n.3, p.207-223, 1984.

SCOTT, M.J.; RANSAY, F.L.; KEPLER, C.B. Distance estimation as a variable in estimating bird numbers. Studies in Avian Biology, n.6, p.334-341, 1981.

SHAFFER, M.L. Minimum population sizes for species conservation. Bioscience, v.31, n.2, p.131-134, 1981. 
SHAW, J.H. Introduction to wildlife management. New York: McGraw-Hill, 1985. $316 \mathrm{p}$.

SHUGART, H.H.; JAMES, D. Ecological sucession of breeding bird populations in Northwestern Arkansas. The Auk, v.90, p.62-77, 1973.

SHUGART, H.H.; SMITH, T.M.; KITCHINGS, J.T.; KROODSMA, R.L. The relationships of nongame birds to southern forest types and sucessional stages. In: WORKSHOP MANAGEMENT OF SOUTHERN FOREST FOR NONGAME BIRDS, Atlanta, 1978. Proceedings. Asheville: USDA, Forest Service, 1978. p.516.

SICK, H. Ornitologia brasileira: uma introdução. Brasília: UnB, 1985. 2v.

SICK, H. Ornitologia brasileira. Rio de Janeiro: Nova Fronteira, 1997. 862p.

SILVA, A.F. Composição florística e estrutura de um trecho de mata atlântica de encosta no município de Ubatuba, São Paulo. Campinas, 1980. 153p. Tese (Mestrado) - Instituto de Biologia, Universidade Estadual de Campinas.

SIMBERLOFF, D. Mass extinction and the destruction of moist tropical forests. Zhurnal Oshchei Biologii, v.45, p.767-778, 1984.

SIMBERLOFF, D. Are we on the verge of a mass extinction in tropical rain forests? In: Elliott, D.K. Dinamics of extinction. New York: John Wiley, 1986. p.165-180.

SIMBERLOFF, D.; ABELE, L.G. Refuge design and island biogeography: effect of fragmentation. The American Naturalist, v.120, p.41-50, 1982.

SIQUEIRA, J.D.P. Expressão econômica e social das essências nativas. In: CONGRESSO NACIONAL SOBRE ESSÊNCIAS NATIVAS, Campos do Jordão, 1982. Anais. São Paulo: Instituto Florestal, 1982. v.3, p.1.444-1.459.

SKUTCH, A.F. Studies of tropical American birds. Natural Ornithology Club, n.10, 1972.

SLATKIN, M. Estimating levels of gene flow in natural populations. Genetics, v.99, p.323-335, 1981.

SMITH, K.G. Nongame birds of the Rocky Mountain Spruce-Fir Forest and their management. In: ESTADOS UNIDOS. Department of Agriculture. Management 
of western forests and grasslands for nongame birds. Salt Lake City: Forest Service General Technical Report, 1980. p.258-279.

SOULÉ, M.E. What do we really know about extinction? In: SCHONEWALT-COX, C.M.; CHAMBERS, S.M.; MacBRYDE, B.; THOMAS, W.L. Genetics and conservation. London: Benjamin/Cummings, 1983. p.111-124.

SOULÉ, M.E. Conservation biology: the science of scarcity and diversity. Sunderland: Sinauer Associates Inc., 1986. 584p.

SOUZA, W.W.C. A derrubada das matas em São Paulo. Revista Florestal, v.6, p.1824, 1947.

SPACKMAN, S.C.; HUGHES, J.W. Assessment of minimum stream corridor width for biological conservation: species richness and distribution along mid-order streams in Vermont, USA. Biological Conservation, n.71, p.325-232, 1995.

SPIX, J.B. von. Avium species novae, quas in itinere per Brasiliam annis 1817-20 collegit et descripti. Monachii: Hubschmann, 1825. 2v.

SPIX, J.B. von; MARTIUS, K.F.P. von. Viagem pelo Brasil: 1817-1820. São Paulo: EDUSP, 1981. v.1, 262p.

SZARO, R.C. Factors influencing bird populations in Southwestern Riparian Forests. In: ESTADOS UNIDOS. Department of Agriculture. Management of western forests and grasslands for nongame birds. Salt Lake City: Forest Service General Technical Report, 1980. p.403-418.

TAUNAY, A.E. Os primeiros cafezais do oeste de São Paulo. Revista do Instituto do Café, v.2, p.626-631, 1935.

TERBORGH, J. Preservation of natural diversity: the problem of extinction-prone species. Bio-Science, n.24, p.715-722, 1974.

TERBORGH, J. Faunal equilibria and the design of wildlife preserves. In: GOLLEY, F.B.; MEDINA, E. Tropical ecological systems. Berlin: Springer-Verlag, 1975. p.369-380. 
TERBORGH, J. The conservation status of neotropical migrants: present and future. In: KEAST, A.; MORTON, E.S. Migrant birds in the neotropics: ecology, behavior, distribution and conservation. Washington: Smithsonian Institution Press, 1980.

TERBORGH, J. Diversity and the tropical rain forest. New York: American Library, 1992.

TERBORGH, J.; WESKE, J.S. Colonization of secondary habitats by Peruvian birds. Ecolgy Monographs, n.50, p.765-782, 1969.

THOMAS, J.W.; MASER, C.; RODIEK, J.E. Wildlife habitats in managed forests: the Blue Mountains of Oregon and Washington. Washington: Forest Service Agriculture, 1979. 512p. (Handbook, 553).

TOLEDO, M.C.B. Avifauna em duas reservas fragmentadas de Mata Atlântica na Serra da Mantiqueira, São Paulo. Piracicaba, 1993. 112p. Dissertação (Mestrado) Escola Superior de Agricultura "Luiz de Queiroz", Universidade de São Paulo.

TRAMER, E.J. Bird species diversity: components of Shannon's formula. Ecology Monographs, v.50, n.2, p.927-929, 1969.

VASCONCELOS, L.A.S.; MOTTA JÚNIOR, J.C. A importância das síndromes de dispersão para a reconstituição de matas ciliares. In: SIMPÓSIO SOBRE MATA CILIAR, São Paulo, 1989. Resumos. São Paulo: Instituto de Botânica, 1989. p.48.

VEIGA, A.A. Coletânea de assuntos técnicos: área de dasonomia. São Paulo: Instituto Florestal, 1985. 139p.

VELOSO, H. P. Classificação da vegetação brasileira adaptada a um sistema universal. Rio de Janeiro: IBGE, 1991. 124p.

VIANA, V.M. Biologia e manejo de fragmentos florestais naturais. In: CONGRESSO FLORESTAL BRASILEIRO, 6. Campos do Jordão, 1990. Anais. São Paulo: SBS;SBEF, 1990. v.1, p.113-118.

VICKERY, J.A. The effects of surface water acidification on riparian birds with particular reference to the dipper. Oxford, 1988. Thesis (Ph.D.) - University of Oxford. 
VICKERY, J.A. Breeding densities of dippers Cinclus cinclus, grey wagtails Motacilla cinerea and common sand pipers Actitis hypoleucus in relation to the acidity of streams in S.W.Scotland. Ibis, n.133, p.178-185, 1991.

VICTOR, M.A.M. A devastação florestal. São Paulo: Sociedade Brasileira de Silvicultura, 1975. 48p.

VIELLIARD, J.M.E. Catálogo dos troquilídeos do Museu de Biologia Mello Leitão. Santa Teresa: Museu de Biologia Mello Leitão, 1994. 94p.

VIELLIARD, J.M.E. ; SILVA, W.R. Nova metodologia de levantamento quantitativo da avifauna e primeiros resultados no interior do Estado de São Paulo, Brasil. In: ENAV, 4. Recife, 1989. Anais. Recife: UFRPe, 1989. p.117-151.

WALSH, P.M. The use of seabirds as monitors of heavy metals in the marine environment. In: FURNESS, R.W.; RAINBOW, P.S. Heavy metals in the marine environment. New York: CRC Press, 1990. p.183-204.

WARMING, E. Lagoa Santa: contribuição para a geographia phytobiologica. In: FERRI, M. Lagoa Santa e a vegetação de cerrados brasileiros. São Paulo: EDUSP, 1973. p.7-284.

WETTSTEIN, R.R. von Vegetationsbilder aus südbrasilien. Leipzig und Wien: Franz Deuticke, 1904. 126p.

WHITMORE, T.C. An introduction to tropical rain forest. Clarendo: Oxford Press, 1991. 226p.

WIED-NEUWIED, M.A.P. von Voyage au Brésil dans les annes 1815 et 1817. Paris: Arthur Bertrand, v.1, 1821.

WILCOX, B.A. In situ conservation of genetic resources: determinants of minimum area requerements. In: WORLD CONGRESS ON NATIONAL PARKS. Bali, 1982. Proceedings. Washington: Smithsonian Institution Press, 1982.

WILLIS, E.O. The composition of avian communities in remanescent woodlots in southern Brazil. Papéis Avulsos de Zoologia, n.33, p.1-25, 1979.

WILLSON, M.F. Avian community organization and habitat structure. Ecology monographs, v.55, n.5, p.1017-1029, 1974. 
WILSON, A.M; LINDENMAYER, D. Wildlife corridors: their potential role in the conservation of biodiversity in rural Australia. Australian Journal of Soil and Water Conservation, v.9, p.22-28, 1996. 